\title{
ASPECTOS DE QUALIDADE DE VIDA E DE SUBJETIVIDADE NA PROMOÇÃO DA SAÚDE VOCAL DO PROFESSOR
}

\author{
REGINA ZANELLA PENTEADO
}

São Paulo

2003

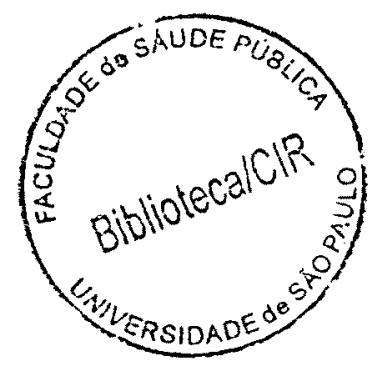




\title{
ASPECTOS DE QUALIDADE DE VIDA E DE SUBJETIVIDADE NA PROMOÇÃO DA SAÚDE VOCAL DO PROFESSOR
}

\author{
REGINA ZANELLA PENTEADO
}

Tese apresentada ao Departamento de Práticas de Saúde Pública, da Faculdade de Saúde Pública da Universidade de São Paulo (FSP/USP), como parte dos requisitos para a obtenção do grau de Doutora em Saúde Pública.

Área de concentração:

Serviços de Saúde Pública

Orientadora:

Prof $^{a} \mathrm{Dr}^{2}$ Isabel Maria Teixeira Bicudo Pereira

São Paulo

2003

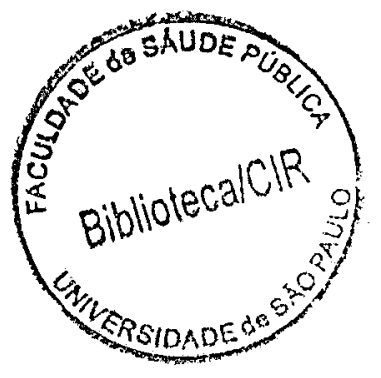




\title{
Dedicatória:
}

\section{Dedico essa pesquisa ao Belarmino César, com todo meu amor;}

E a todos os professores e professoras que têm paixão por aquilo que fazem...

\author{
"A palavra é o traje com o qual o que se quer dizer se veste \\ para contar desejos e revelar ao mundo a nossa face \\ A palavra, \\ A palavra ao desvendar segredos revela mistérios \\ Rompe no silêncio, abre suas asas e nos devora \\ A palavra, \\ A palavra fala aos continentes e é que nos nomina \\ Dá voz aos sentidos, abre os corações e nos revela \\ A palavra, \\ Viver é só um fato, não é nada \\ O tempo fia o que se diz e pronto \\ A palavra nos leva pela vida afora \\ E vida afora ela nos faz refém \\ A palavra, a palavra..."
}

(Renato Teixeira: Palavra)

"O maior mistério é haver mistérios Ai de mim, senhora natureza humana Olhar as coisas como são, quem dera! E apreciar o simples que de tudo emana Nem tanto pelo encanto da palavra, Mas pela beleza de se ter a fala..."

(Renato Teixeira: O maior mistério) 


\section{Agradeço a Deus, pelas pessoas que coloca em meu caminho, especialmente...}

Ao Belarmino César, meu marido e companheiro de tudo nessa vida.

Aos meus pais, Ni e Bet e à minha sogra, $\mathrm{D}$. Nita, pelo apoio constante nas horas precisas e à minha familia, com tantos exemplos de professores e professoras.

À Isabel Maria Teixeira Bicudo Pereira, pela tranqüilidade com que me orientou no mestrado e doutorado; e aos docentes e funcionários da Faculdade de Saúde Pública- FSP/USP.

Às amigas queridas, Reginalice Cera da Silva, Regina Yu Shon Chun e Emilse Aparecida Merlin Servilha, sempre presentes em todos os momentos desse trabalho e nos contextos especiais da minha vida profissional.

À Léslie Piccolotto Ferreira e Mara Behlau; alicerces da minha formação na área de voz.

À Gisleine Trigo Silveira, pelas contribuições nas bancas de qualificação e defesa.

Às amigas Marisa Krüger e Neide Ferraz de Campos Barone, pelo apoio e participação fundamental na realização do grupo focal dessa pesquisa.

À fga. Carla Regina Marin, pela transcrição do grupo focal e à prof ${ }^{\mathrm{n}}$ Isalina e ao Arlei, pela competente assessoria em estatística.

À minha querida tia Marilí Penteado, pela generosidade do trabalho de correção da tese, estendendo-me a sua mão com dedicação e carinho e contribuindo com comentários de quem muito tem a dizer sobre o professor. Ä minha prima Ana Elisa, pelas contribuições oportunas.

Aos professores de Ensino Médio de Rio Claro que, valendo-se da palavra, muito ensinaram sobre saúde vocal, a partir do que é "ser professor". Aos diretores e coordenadores pedagógicos, por viabilizarem os contatos com os professores dessa pesquisa.

À Unifono/Cooperativa de Fonoaudiologia de Rio Claro e Região, por ceder o espaço da sua sede para a realização do grupo focal dessa pesquisa.

Ao grupo de docentes, discentes e funcionários do Curso de Fonoaudiologia da Universidade Metodista de Piracicaba (UNIMEP), pelas oportunidades de trocas e convivência que, pouco a pouco, vão tecendo o encantamento com um saber e uma prática sobre "ser professor".

Ao Bito e Valéria; Cláudio, Durvalina, Claudinho, Nália e Natália; Fábio, Valéria e Valquíria; Aldo, Marisa e Juliana; Tuto, Adriana e Bianca; Toni, Vânia e Júlia; Eldon e Marisa; João Paulo e Janise; Heraní; Renata; Rubens e Nenê; Fefeu e Catarina; Rosana; Maria Cristina Carneiro; Keila; Helene; Suzana Giannini; Orlando e Lúcia (e Thales!); Daniel e Júlia - pela amizade que supera distâncias e que atravessa o tempo.

Ao Renato Teixeira, lvete Miranda, Natan Marques, Ricardo Zóhyo, Chico Teixeira, Valter Gonçalves, Erivelto Gamero e Pena Branca; pelo carinho, beleza e simplicidade de uma amizade que já começa se fazendo "permanente", mas se renova e se firma na surpresa e na leveza de cada encontro dessa estrada ...

A CAPES, pelo financiamento dessa pesquisa. 


\section{RESUMO}

PENTEADO, R.Z. - "Aspectos de qualidade de vida e de subjetividade na promoção da saúde vocal do professor”. São Paulo, 2003. [Tese de Doutorado Faculdade de Saúde Pública da Universidade de São Paulo - FSP/USP].

Esta pesquisa tem como objetivo investigar as relações entre qualidade de vida e saúde vocal do professor. Utiliza-se de referenciais interdisciplinares e assume a característica de pesquisa qualitativa, que vale-se da triangulação de dados de caráter quantitativo (instrumentos QVV e WHOQOL/Breve) e qualitativo (grupos focais). Busca-se compreender o fenômeno da qualidade de vida do professor em suas relações com a saúde vocal, sob uma perspectiva que incorpore a subjetividade, as percepções, os significados e os sentidos construidos social, cultural e historicamente, nos contextos, condições e organização do trabalho e da vida do trabalhador professor. Os dados mostram a relação entre qualidade de vida e voz/saúde em diversos aspectos da vida cotidiana. As condições e organização do trabalho docente apresentam problemas que atingem o ato educativo, a subjetividade e o processo saúde-doença do professor e demandam ações para a Promoção da Saúde na escola. Esta pesquisa visa contribuir para o conhecimento sobre a realidade de vida e trabalho do professor e suas necessidades a fim de subsidiar reflexões e incrementar, qualitativamente, as propostas fonoaudiológicas na promoção da saúde vocal deste trabalhador.

Descritores: Saúde vocal; Promoção da Saúde; saúde do trabalhador, trabalho docente; saúde do professor, Voz do professor, Qualidade de Vida; Saúde Pública; Fonoaudiologia 


\section{SUMMARY}

PENTEADO. R.Z. - "Aspects of quality of life and subjectivity in the vocal health raising of the teacher". São Paulo, 2003. [Tese de Doutorado-Faculdade de Saúde Pública da Universidade de São Paulo - FSP/USP].

This research has as purpose to search the relations between the quality of life and vocal health of the teacher. Interdisciplinary references had been made use and the characteristic of qualitative research had been taken on, based on the data triangulation of quantitative (QVV and WHOQOL/Brief) and qualitative (focal groups) character. It had been searched to understand the quality of teacher's life phenomenon in their relationships with the vocal health, beneath the perspective which incorporates the subjectivity, the perception, the meanings and the senses made social, cultural, and historically, in the contexts conditions and work organizations and the teacher's life. The conclusion shows the relationship between quality of life and vocal health in several aspects in daily life. The teaching work conditions and organizations presents some problems that affects the education act, the subjectivity and the teacher's health/illness process and that demands Health Promotion actions in the school. This research aims to contribute to the knowledge about the reality of the life and the teacher's work and their needs in order to subsidize reflections and develop, qualitatively the speech-language pathology purposes to the vocal health of this worker.

Key words: Vocal health; Health Promotion; Worker health; Speech-language pathology; Teacher's health; Teaching work; Teacher's voice; Quality of life; Public health. 
CAPÍTULO 1 - O professor, seu trabalho, sua vida e processo saúde/doença

1) Ser professor - amor e dor no trabalho docente

2) A mulher professora - questões de gênero, subjetividade e vida privada 33

3) A relação professor-alunos: a autoridade e a questão da indisciplina 37

4) Processo saúde-doença de trabalhadores professores 46

5) Licenças de saúde: adesão e resistência no trabalho docente 52

6) Perspectivas para a investigação da saúde vocal do professor 57

\section{CAPÍTULO 2 - Objetivos}

\section{CAPÍTULO 3 - Método}

1) Delineamento da pesquisa $\quad 64$

2) Fase de planejamento da pesquisa

3) Sujeitos da pesquisa 69

4) Primeira fase da pesquisa (questionários) $\quad 70$

5) Segunda fase da pesquisa (grupo focal) 68

\section{CAPÍTULO 4 - Resultados e Discussão}

\section{Primeira fase da pesquisa}

1) Considerações sobre as escolas e sobre a situação de aplicação dos questionários $\quad 80$

2) Análise descritiva das questões $\quad 92$

3) Avaliação da consistência dos domínios da QVV 127

4) Avaliação da consistência dos domínios da QV 129

5) Estudo da associação entre os dominios da QV e os da QVV 132

6) Comparação dos sexos 134

7) Associações de idade, $n^{\circ}$ períodos que leciona e Como avalia a voz com a QVV e QV 138

8) Comparação das escolas $\quad 146$

9) Faces de "Chernoff" 149

Segunda fase da pesquisa

I-Categorias, temas e conjuntos temáticos

1) Organização do trabalho docente

1.1 - Relações sociais no trabalho 154

1.1.1 -Relação professor-alunos 154

1.1.2 - Relação docente/administração-coordenação 158

$\begin{array}{ll}1.2 \text { - Processo ensino-aprendizagem } & 161\end{array}$

1.3 - Trabalho docente e constituição da subjetividade 164

2) Organização da vida privada

2.1 - Implicações do trabalho na família $\quad 166$

2.2 - Implicações do trabalho no lazer $\quad 167$

3) Usos da voz nos contextos cotidianos

$\begin{array}{ll}3.1-\text { Usos da voz no trabalho docente } & 170\end{array}$

$\begin{array}{ll}3.2-\text { Usos da voz na vida privada } & 173\end{array}$

4) Processo saúde-doença do trabalhador professor

4.1 - Implicações do trabalho docente no corpo e processo saúde-doença do professor $\quad 175$

$\begin{array}{ll}4.2 \text { - Noções de higiene vocal/saúde vocal } & 180\end{array}$

4.3 - Preocupações e represetnações acerca do processo saúde-doença vocal $\quad 182$

4.4 - Percepção e identificação de um problema de voz/saúde vocal $\quad 184$

$\begin{array}{ll}4.5 \text {-Estratégias de enfrentamento das alterações e problemas vocais } & 186\end{array}$

II-Processos de interanimação dialógica $\quad 188$

CAPÍTULO 5 - Considerações Finais $\quad 191$

BIBLIOGRAFIA $\quad 199$ 


\section{LISTA DE TABELAS E FIGURAS}

\section{TABELAS}

Tabela 1. Análise descritiva da amostra para sexo, idade e $n^{\circ}$ de períodos que leciona 92

Tabela 2/a - Análise descritiva das respostas à questão Como avalia a sua voz 93

Tabela 2/b - Classes de freqüência do domínio global do QVV 94

Tabela 3 - Análise descritiva das respostas, escores, frequências e porcentagens do QVV 99

Tabela 4 - Análise descritiva das respostas, escores, freqüências e porcentagens do QV 105

Tabela 5 - Análise descritiva das respostas, escores, freqüências e porcentagens do Item VIII do SF36

Tabela 6 - Análise descritiva das respostas, escores, freqüências e porcentagens do Item IX do SF36

Tabela 7 - Análise descritiva dos domínios do QVV

Tabela 8 - Coeficientes de correlação de Spearman e teste " $t$ " para o cruzamento dos domínios do QVV, dois a dois

$\begin{array}{lr}\text { Tabela } 9 \text { - Análise da consistência dos domínios do QVV } & 128 \\ \text { Tabela 10 - Análise da consistência dos domínios do QV } & 129\end{array}$

Tabela 11 - Coeficientes de correlação de Sperman e teste " $t$ " para o cruzamento dos domínios do QV, dois a dois

Tabela 12 - Análise da consistência dos domínios do QV

Tabela 13 - Coeficientes de correlação de Sperman e teste " $t$ " para o cruzamento dos domínios do QVV com dos domínios do QV

Tabela 14 - Médias, medianas e desvios padrões para os domínios do QVV e QV

Tabela 15 - Médias, medianas e desvios padrões para as questões não englobadas pelos domínios da QVV e QV e do SF36, em função do sexo

Tabela 16 - Coeficientes de correlação de Sperman e teste " $t$ " para o cruzamento de Como avalia a sua voz; Como avalia a sua qualidade de vida; Quão satisfeito está com sua saúde com os domínios da QVVe os domínios da QV

Tabela 17 - Coeficientes de correlação de Sperman e teste " $t$ " para o cruzamento de Idade, $n^{\circ}$ períodos que elciona, Como avalia a sua voz; Como avalia a sua qualidade de vida e Quão satisfeito está com sua saúde com as questões não englobadas pelos domínios da QVV e os domínios da QV

Tabela 18 - Coeficientes de correlação de Sperman e teste " $\mathrm{t}$ " para o cruzamento de Como avalia a sua voz com questões englobadas pelo QVV e QV

Tabela 19-Médias, medianas e desvios padrões para os domínios da QVV e Como avalia a sua voz, em função da escola

Tabela 20 - Médias, medianas e desvios padrões para os domínios da QV em função da escola

\section{FIGURAS}

Figura 1 - Coeficientes de correlação de Sperman e teste " $t$ " para o cruzamento dos domínios do QVV com dos domínios do QV

Figura 2 - Médias dos domínios do QVV e do QV em função do sexo

Figura 3 - Coeficientes de correlação de Sperman e teste " $t$ " para o cruzamento de Idade, $\mathrm{n}^{\circ}$ períodos que elciona, Como avalia a sua voz; Como avalia a sua qualidade de vida e Quão satisfeito está com sua saúde com os domínios do QVV e os domínios do QV

Figura 4 - Média dos domínios da QVV em funç̃o da escola onde o professor trabalha 


\section{INTRODUĊÃO}

... "O fato é que todos aqueles que ainda têm a ousadia de falar e escrever acreditam, ainda que de forma tênue, que o seu falar faz uma diferença. Isso é de crucial importância para o educador, e desta crença depende o seu sono e o seu acordar porque, com que instrumentos trabalha o professor?

Com a palavra. O educador fala"...

(Rubem Alves, 1998; p. 27)

O questionamento de Rubens Alves, no trecho acima, - "...com que instrumentos trabalha o professor?" - trata-se justamente do objeto central desta pesquisa. Interessa compreender as relações entre qualidade de vida e saúde vocal do professor. Para tanto, abordo nesta introdução, aspectos que evidenciam e justificam estudos do teor aqui proposto, a saber: a promoção da saúde na escola, a abrangência e implicações dos conceitos de voz/linguagem e a relação com a qualidade de vida, histórico da atuação fonoaudiológica com a voz do professor e a atenção à saúde vocal dessa categoria profissional. Apresento-os em itens, de forma a facilitar a visualização e compreensão dos mesmos, e finalizo essa parte introdutória destacando aspectos e fatos históricos que reiteram a pertinência desta pesquisa e as contribuições que dela podem advir.

\section{Promoção da saúde na escola}

Promover a saúde implica, necessariamente, considerar a subjetividade ${ }^{1}$ das pessoas e a qualidade de vida nos contextos do cotidiano de sujeitos e comunidades que envolvem ambientes de convívio social e as relações a elas inerentes.

\footnotetext{
${ }^{1}$ Nesse trabalho compreende-se a subjetividade conforme considerada por SOUZA (1999), enquanto composições provisórias que delimitam as contornos atuais e as maneiras pelas quais as pessoas se fazem sujeitos no processo contínuo da sua existência.
} 
A partir das Conferências Mundiais de $\operatorname{Saúde}^{2}$, a participação ativa dos sujeitos e das comunidades é destacada para a viabilização do processo de promoção da saúde, compreendido como investimentos e ações que propiciam o desenvolvimento integral e fortalecem as pessoas, aumentando sua auto-estima. Ao mesmo tempo, tal participação capacita-as à identificação, ao controle, à ação e transformação para melhoria dos fatores que afetam e determinam a qualidade de vida e a saúde, no sentido da eqüidade, da construção de políticas públicas e formação de ambientes saudáveis para melhor qualidade de vida das pessoas (WESTPHAL, 2000; BUSS, 2000 e MINISTÉRIO DA SAÚDE, 2001).

Essa lógica da promoção da saúde importa uma visão afirmativa de saúde, compreendida como um atributo da vida construído na história singular e coletiva - do sujeito e da comunidade; saúde seria, aqui, a capacidade para desenvolver suas potencialidades pessoais no sentido de realizarem suas aspirações, satisfazerem suas necessidades, responderem aos desafios e alternativas da vida e obterem bens sociais, num processo dinâmico que inscreve o sujeito, seu corpo, seu trabalho, suas emoções, sua vida (DE SOUZA e KALICHMAN, 1992; OPAS/OMS, 1996; MINISTÉRIO DA SAÚDE, 1996; NUTBEAM, 1996; KICKBUSCH, 1996; BRITO, 1999; BUSS, 2000).

O processo de Promoção da Saúde encontra-se apoiado no movimento e nas propostas de cidades,municípios e ambientes saudáveis numa iniciativa da Organização Mundial da Saúde (OMS) e Organização Pan-Americana da Saúde (OPAS) que pressupõem a existência de problemas concretos de pessoas que convivem no mesmo local ou território (WESTPHAL, 2000). Assim, durante a década de 1990, começam a ser difundidas as propostas de formação de ambientes saudáveis, dentre as quais a de Escolas Saudáveis (E.S.) ou Escolas Promotoras de Saúde (E.P.S.), que visam à promoção da saúde de estudantes e professores e contribuem, dessa forma para a saúde e qualidade de vida da comunidade escolar e do seu entorno (OPAS/OMS, 1996).

SILVA (2002) considera que essa proposta comporta uma concepção de escola como cenário estratégico para a construção de uma vida saudável e de uma cidade igualmente saudável. Representa uma das mais importantes estratégias para reverter os desafios da promoção da saúde, pois tem sua origem na comunidade local, respeitando sua história, cultura

\footnotetext{
${ }^{2}$ Algumas principais conferências e documentos mais importantes podem ser citados, tais como: a Carta de Ottawa (Canadá, 1986), a Declaração de Adelaide (Austrália, 1988), a Declaração de Sundswal (Suécia, 1991), a Declaração de Bogotá (Colômbia, 1992) e a Declaração de Jacarta (Indonésia, 1997).
} 
e saber. Ao mesmo tempo em que atende suas esperanças, necessidades e expectativas de saúde, de educação e de desenvolvimento social, estimula o exercício democrático de pensar e de propor soluções, envolvendo cada cidadão no controle de sua saúde e qualidade de vida.

Tal proposta visa à construção de uma escola cidadã, de maneira que esse equipamento social protagonize a ação de mudança do quadro desfavorável das condições de vida da população. A partir do papel de construção do conhecimento, reflexão crítica e um processo de desenvolvimento e aprendizagem que lhe cabe, é desejável que a escola se configure como espaço permanente de inclusão, participação e interlocução com setores e demandas da sociedade. Deve contribuir para a inserção das questões relativas à saúde no conhecimento construído e para uma educação que tem como meta formar cidadãos responsáveis, plenos em direitos e deveres e solidários uns com os outros e com o meio ambiente em que vivem e convivem.

A iniciativa das E.P.S. pretende superar aquele modelo de relação saúde/educação, no qual as escolas eram meras realizadoras de programas e ações de saúde elaborados e impostos pelos profissionais e instituições de saúde (programas esses que, muitas vezes, se apresentavam distantes dos interesses e das reais necessidades da comunidade escolar), para avançar no sentido de as comunidades escolares assumirem papel ativo e dinamizador na criação de oportunidades e iniciativas de educação em saúde (IERVOLINO, 2000).

Uma E.P.S. caracteriza-se por ser uma escola saudável, com gestão escolar e ensino de qualidade; caracteristicas físicas e ambiente agradável, cuidado e conservado; contar com o envolvimento e preocupação de toda a comunidade escolar voltada ao bem estar de todos; com a participação ativa do alunado e da comunidade junto ao projeto pedagógico; com um relacionamento cordial e respeitoso entre profissionais e comunidade escolar, dentre outros aspectos que contribuam para fazer da escola um ambiente promotor de estilos de vida saudáveis (SILVEIRA, 2000).

A proposta de E.P.S. implica uma revisão e re-orientação da atenção à saúde da comunidade escolar, na perspectiva da integralidade e da criação de ambientes físico e psicossocial saudáveis, o que envolve as relações interpessoais, os aspectos emocionais e as interações sociais que afetam o bem-estar e a produtividade dos alunos e do pessoal da escola, para que o ambiente de trabalho seja ameno e saudável (OPAS 1996; OPAS/OMS, 1998; PELICIONI, 2000; SILVA, 2002). Assim, permite focalizar questões particulares importantes, 
tais como o comprometimento da voz e da fala que atinge os trabalhadores da educação prejudicando a sua saúde e sua relação com a vida (SILVA, 2002). E, aqui, entende-se que as questões do trabalho docente e de saúde do trabalhador professor ${ }^{3}$ tomam lugar!

\section{Qualidade de vida}

Enquanto uma das iniciativas para a promoção da saúde, a proposta de E.P.S. relaciona-se com a qualidade de vida das pessoas e da comunidade em que a escola se insere. Qualidade de vida é uma representação criada a partir de parâmetros subjetivos e objetivos, composta por elementos positivos e negativos, abrangendo significados que refletem percepções, necessidades, conhecimentos, valores, experiências, sentimentos e comportamentos de indivíduos e coletividades. É uma noção aproximada do grau de satisfação das pessoas no trabalho, na vida familiar, amorosa, social e com as condições ambiental, psico-emocional, físicas, de competência funcional e saúde geral; é o fruto de uma construção social marcada pela relatividade cultural, pois pressupõe uma síntese dos elementos e padrões de determinada sociedade ou do segmento populacional que a compõe (GRUPO WHOQOL, 1998; MINAYO, HARTZ e BUSS, 2000).

Qualidade de vida é um conceito amplo que abrange a complexidade de um construto subjetivo, multidimensional e composto por elementos de avaliação tanto positivos como negativos, definida como a percepção do indivíduo de sua posição na vida no contexto da cultura e sistema de valores nos quais ele vive e em relação aos seus objetivos, expectativas, padrões e preocupações (GRUPO WHOQOL, 1998; FLECK et al, 1999 e FLECK, 2000). Assim, analisar a qualidade de vida de uma comunidade significa considerar, também, as experiências subjetivas e afetivas, a percepção e o grau de satisfação dos sujeitos sobre a sua própria condição de existência, bem como as expectativas que eles têm de transformação dessa condição (PEREIRA e ENGELMANN, 1993 e RAMÍREZ, 2001).

\footnotetext{
${ }^{3}$ Nesse trabalho, quando se utiliza o vocábulo professor entende-se professor e professora.
} 


\section{Voz/linguagem e qualidade de vida}

Se a qualidade de vida é uma representação, fruto de um construto social e cultural, pode-se dizer, então, que a qualidade de vida é perpassada pela linguagem, mediador semiótico mais importante dentre os signos, constituída no interior e nos limites de determinada(s) formação(ões) social(ais) que configuram sistemas de referência pessoal e social; elemento responsável pelas interações sociais, pela constituição da subjetividade e fonte do conhecimento e da ação humana sobre o mundo (FRANCHI, 1977; POSSENTI, 1988; BAKHTIN, 1992; GERALDI, 1997; WERTSCH, DEL RIO e ALVAREZ, 1998).

A linguagem se constitui em aspecto importante para a promoção da saúde e qualidade de vida das pessoas. A voz é fundamental na comunicação oral e na relação interpessoal, constitui, portanto, parte do movimento incessante da linguagem e socialização humana (MARTZ, 1987; FERREIRA, ALGODOAL e SILVA, 1997/1998 e DRAGONE, 2000). A voz ganha sentido no contexto interativo da relação dialógica/comunicativa, já que a voz varia conforme o contexto de produção e a interação social (MÄRTZ, 1987 e 1999; SERVILHA, 2000; CHUN, 2000 e 2001).

A voz humana é o som de características individuais e relaciona-se com a autoimagem e auto-estima pessoal, na medida em que espelha a identidade do sujeito; é um recurso para criação de vínculos na interação, o que possibilita à pessoa atingir o outro e relacionar-se com ele. (BEHLAU e PONTES, 1995; VIEIRA, 1996; MÄRTZ, 1999; DRAGONE, 2001). Entretanto, vozes alteradas ou disfônicas podem produzir um impacto negativo no ouvinte ou, até mesmo, influenciar os relacionamentos interpessoais, distanciando a pessoa de seus interlocutores.

Aqui, entende-se a voz humana como constitutiva do sujeito e de sua singularidade, pois, como afirma OLIVEIRA JR (2001), ela é condição de existência e de apresentação do sujeito; ou, ainda, materialidade fônica que traz à presença do mundo o ser e a sua solicitação subjetiva de se expressar e o seu desejo de significar. A intenção de falar é atravessada por assertividades, angústias, medos, desejos de esclarecimento, poder, sedução (MARTZ, 1999). Essa é uma das razões pelas quais muitos autores consideram que a queixa de voz está necessariamente comprometida com o uso da voz na interação verbal e na necessidade de 
estabelecimento de comunicação com o outro, evidenciando, inclusive, os confrontos e as contradições entre sentimentos e idéias do sujeito e o contexto em que se dá a comunicação.

Segundo CHUN (2000) e SERVILHA (2000), a voz de cada falante apresenta uma complexidade e riqueza de recursos fônicos, de opções de comportamentos e atitudes vocais, variações e ajustes fonatórios que sofrem a interferência de aspectos da qualidade de vida e da história singular de cada um, assim como de aspectos das representações e sentidos produzidos nos contextos interativos/dialógicos e dos posicionamentos que o sujeito assume nas relações sociais em que se envolve nos seus contextos cotidianos ${ }^{4}$.

Autoras como MARTZ (1999), FERREIRA (1999-a), SERVILHA (2000), CHUN (2000), GARCIA (2000), GOBBI (2000) e ALGODOAL (2002), apóiam-se em pressupostos sociológicos e enfatizam os aspectos simbólicos e as determinações sociais, culturais e históricas sobre a produção vocal e a influência desses aspectos sobre a voz, observada como saúde vocal. Cabe, aqui, ressaltar que no campo da Fonoaudiologia são ainda incipientes as pesquisas que transcendem a dimensão orgânica da voz, numa abordagem como dessas autoras, ou seja, que visam contemplar interferências do contexto social, das relações interpessoais, dos conflitos e das significações, que se instauram e se constroem nas situações sociais discursivas.

Diversos autores reconhecem e reiteram o papel da voz como fator relevante para o desempenho profissional e recursos da atuação do professor em sala de aula e, especialmente, na relação professor-aluno, enquanto componente constitutivo da identidade do professor como trabalhador e do impacto do docente sobre o discente ou componentes do processo ensinoaprendizagem (DRAGONE, 2000 e 2001-b; GRILLO, 2000 e 2001 e SERVILHA, 2000 e 2001). Autores como CHUN (2000 e 2001) e SERVILHA (2000) evidenciam as mudanças da voz a partir dos enquadres, posicionamentos e alinhamentos que o sujeito assume, nos diferentes papéis sociais que representa em sua vida. Em tal sentido, no contexto da docência, SERVILHA (2000 e 2001) evidenciou que, nas relações sociais e papéis de professor e aluno bem como nos alinhamentos e posicionamentos implicados nessa relação - as variações da voz do professor expressavam, com suas sutilezas, diferentes significados, configurando parte integrante da relação ensino-aprendizagem, fundamental para indicar aos alunos os diferentes propósitos da aula.

\footnotetext{
${ }^{4}$ Neste trabalho, utilizo contextos cotidianos entendendo-se como situações de vida familiar, social e de trabalho.
} 
No entanto, DRAGONE (2000) e GRILLO (2000 e 2001) demonstram, em seus estudos, que o professor ainda não se deu conta da importância da voz no contexto do trabalho docente (ao menos não da maneira como ela vem sendo compreendida e valorizada pelos fonoaudiólogos). DRAGONE (2000) observou que os professores consideram o papel da voz no exercício da docência a partir da sua aplicação como recurso didático, recurso controlador da disciplina e recurso revelador da emoção; sendo o papel de recurso didático o mais mencionado e o de revelador da emoção o menos citado. A autora acrescentou, ainda, que dos parâmetros da qualidade vocal, o aspecto mais citado pelos professores é o da intensidade de voz, utilizado com a intenção de controle da disciplina dos alunos ou para destacar pontos importantes do seu discurso ou do conteúdo da disciplina.

Para melhor compreender o fato de o professor atribuir pouca importância e pequeno valor à sua voz e saúde vocal, SERVILHA (2001) e DRAGONE (2001) propõem avançar no entendimento de como o sujeito percebe sua própria voz e com ela se relaciona nos diferentes papéis e posicionamentos do cotidiano, assim como observar com mais profundidade os impactos e interferências da voz - alterada ou não - sobre as relações sociais cotidianas e a vida das pessoas, não se esquecendo dos determinantes das variações vocais presentes no cotidiano.

A voz deve ser pensada em relação à saúde geral da pessoa (SILVA, 1998) e, assim, e diversos autores consideram que as alterações de voz produzem um impacto não somente sobre o indivíduo e sua saúde, mas também sobre a sua qualidade de vida, podendo provocar sofrimentos, dificuldades, limitações e restrições nas esferas física, psico-emocional, social e profissional, com prejuizo devastador na vida diária (SMITH et al, 1996; JACOBSON et al, 1997; HOGIKYAN e SETHURAMAN, 1999 e BEHLAU, 2001). Os problemas de voz têm implicações sobre a auto-imagem, os relacionamentos sociais e afetivos, as necessidades comunicativas diárias, as opções de.lazer, os projetos pessoais, o exercício da profissão e as investidas para a obtenção de um emprego ou, ainda, para a almejada ascensão social e profissional - especialmente naquelas funções que demandam a comunicação oral e o uso da voz (BEHLAU, MADAZIO, FEIJÓ e PONTES, 2001). 
RODRIGUES, AZEVEDO e BEHLAU (1996) assinalam que os profissionais que utilizam a voz em seu trabalho estão mais expostos às disfonias ${ }^{5}$. O risco vocal nas profissões pode variar de discreto a elevado, comprometendo a saúde vocal e a longevidade da carreira. A maior prevalência de alterações vocais e disfonias, em profissionais da voz falada, está entre os professores - que representam a categoria de maior risco vocal - variando de moderado a severo (VIEIRA, 1996; SMTTH et al., 1997; MORTON e WATSON, 1998; BEHLAU, ANDRADE, MADAZIO e REHDER, 1999; DRAGONE, 2001 e BEHLAU, 2001-c).

Os professores, desde os trabalhos pioneiros no Brasil, como os de PINTO e FURCK (1988), se configuram como uma das categorias profissionais pelas quais os fonoaudiólogos vêm se dedicando e têm se interéssado, por representarem uma demanda significativa ${ }^{6}$ para o acompanhamento fonoaudiológico, especialmente devido aos diversos problemas vocais que apresentam.

Uma pesquisa realizada com os professores da Prefeitura de São Paulo indica que 60\% dos professores sofriam algum tipo de alteração na voz (CRFA. $2{ }^{a}$ Região, 2001-c e FERREIRA et al, 2003). Outros estudos confirmam essa alta prevalência de queixas e alterações vocais em professores; entretanto foge ao escopo deste estudo a revisão dos mesmos.

PORDEUS, PALMEIRA e PINTO (1996), observaram uma discrepância entre a alta prevalência de alterações vocais e o pequeno percentual de professores que se interessavam em

\footnotetext{
${ }^{5}$ Disfonia é qualquer alteração ou dificuldade na emissão vocal que impeça a produção natural da voz, $\mathrm{cm}$ que pesem características da qualidade vocal, tais como agradabilidade da voz, inteligibilidade da fala, aceitabilidade das características acústicas da voz, adequação da frequêencia ao sexo e idade do falante, intensidade apropriada à comunicação, flexibilidade e resistência adequadas à expressão do sujeito e às suas demandas sociais e profissionais além do grau de desconforto à produção da voz e comunicação e de questões como gosto pessoal, modismo, fatores sexuais, étnicos, sociais e culturais (BEHLAU e PONTES, 1990; BEHL.AU, AZEVEDO e PONTES, 2001). Vários fatores têm sido apontados como possivelmente associados às disfonias, sendo relativos ao comportamento vocal, ao sexo, à idade, ao uso da voz, ao ambiente físico, à organização do trabalho, histórico de saúde e estilo de vida da pessoa (SIMÔES, 2001). Os sinais e sintomas de disfonia podem ser vários, tais como: fadiga vocal, afonia, dificuldade para modular intensidade e frequiência da voz, sinais de desconforto, dor, ardor, esforço, ressecamento e irritação na laringe, alterações na qualidade vocal como rouquidão, aspereza, soprosidade, dentre outros (GOTAAS e STARR, 1993 e MATTISKE, OATES E GREENWOOD, 1998).

${ }^{6}$ Ressalto que a grande procura pelos serviços de Fonoaudiologia se deve ao número elevado de professores, comparado a outras categorias de profissionais da voz, como cantores, atores, radialistas, operadores de telemarketing, por exemplo; mas, na verdade, o que se observa é uma desproporção entre o grande número de professores com sintomas/queixas e problemas vocais e o pequeno número deles que chega a buscar um acompanhamento especializado, sugerindo uma carência de atenção à saúde vocal destes trabalhadores.
} 
compreender questões referentes ao uso da voz e que procuravam atendimento fonoaudiológico. Os autores assinalaram que aqueles que buscavam atendimento especializado só o faziam tardiamente, geralmente a partir de quando começaram a apresentar sintomas vocais, alterações na qualidade da voz e manifestações patológicas da laringe.

Pesquisas recentes calculam os prejuízos sociais e econômicos em função das alterações vocais de professores, pois as enfermidades vocais relacionadas ao trabalho docente têm impacto social, econômico, profissional e pessoal, representando um prejuízo superior a cem milhões de reais por ano no país ${ }^{7}$ (SMITH et al., 1997; CRFA. $2^{a}$ Região, 2001- b).

Entre os fatores predisponentes de disfonia em professores podem ser mencionados: problemas de adaptação profissional, de condições fisicas do ambiente de trabalho, composição da sala de aula, acústica, falta de percepção e de preparo vocal incluindo uso excessivo, abusivo e continuado da voz, agravados por baixa remuneração e falta de reconhecimento social e profissional (NAGANO, 1994; RODRIGUES, AZEVEDO e BEHLAU, 1996; DRAGONE, 1996 e 2000 e BEHLAU, ANDRADE, MADAZIO e REHDER, 1999).

Além disso, a relação de determinação cultural e social do processo saúde-doença, envolvendo as percepções e representações sobre a esse tema, vem sendo apontada por diversos autores da área de saúde coletiva (LAURELL, 1982; BOLTANSKI, 1984; LOYOLA, 1984; RODRIGUES, 1986 e MINAYO, 1997-c). Na Fonoaudiologia, estudos recentes apontam para a importância de considerar que não há um único nexo causal das disfonias em professores, mas sim a co-ocorrência de fatores ambientais, orgânicos e psicossociais.

Em se tratando de saúde, cabe lembrar que vidas humanas e seus fenômenos psicossociais tomam forma e se constroem em relação a uma realidade social e histórica definida, num movimento dialético entre sujeito e sociedade, em que o homem é compreendido como produtor da história e de si próprio (LANE, 1999 e GUARESCHI e JOVCHELOVITCH, 2000). Assim, assume-se que o sujeito, suas percepções, representações, os usos que faz de seu corpo e as interpretações sobre sua funcionalidade e processo saúde-doença, são constituídos pela sociabilidade, pelas condições materiais e simbólicas presentes num contexto históricocultural. O sofrimento - em suas diversas expressões, incluindo o sintoma - muitas vezes é gerado nas tentativas do sujeito em ajustar-se e adequar-se às normas e padrões da cultura nos contextos cotidianos, inclusive no de trabalho. Deste modo, importam, para as ações em saúde, 
as condições de vida e trabalho e como o trabalhador interpreta e se deixa afetar por essas condições (BRANT e BARROS DE MELO, 2001 e RIBEIRO et al., 2002).

RIBEIRO (2001) considera a construção social da doença quando o tema se refere aos transtornos da voz, associados ao trabalho. Segundo esse autor, é preciso deixar de considerar as disfonias de professores trabalhadores apenas numa perspectiva de grupos de risco e passar a buscar a determinação social dos distúrbios e alterações da voz, assumindo a dimensão trabalho como uma categoria sociológica central, no contexto das relações da sociedade. GARCIA (2000), em estudo com operadores de telemarketing, também evidencia a necessidade de compreender a voz numa perspectiva mais ampla e abrangente, relacionando trabalho-voz-relações sociais.

\section{Atenção à saúde vocal do professor}

A demanda de professores com alterações de voz que buscam os serviços fonoaudiológicos acabou motivando o desenvolvimento de outras modalidades de atenção à saúde vocal desses profissionais, que não, unicamente, o atendimento clínico-terapêutico.

PINTO e FURK (1988) foram pioneiras, no Brasil, a declararem a necessidade urgente de prevenção de problemas vocais em professores. Assim, com objetivos de evitar ou minimizar a ocorrência de alterações de voz em professores, foram criadas as primeiras iniciativas de projetos fonoaudiológicos, voltados para a prevenção e promoção da saúde, na escola. Foram publicadas várias experiências como palestras, orientações, projetos de educação vocal, saúde vocal, oficinas de voz, impostação vocal, cursos de aprimoramento/aperfeiçoamento/técnica vocal e programas de saúde vocal dirigidos aos professores (PINTO e FURK, 1988; OLIVEIRA, 1995; PORDEUS, PALMEIRA e PINTO, 1996; CAVALHEIRO, 1997; WOJCIEHWSKI e HEEMANN, 1998; STIER et al., 1998; FERNANDES, 1998; THOMÉ DE SOUZA, 1998; FERREIRA, 1999-a; GRILLO, 2001).

\footnotetext{
${ }^{7}$ Valor estimado a partir de levantamento realizado na cidade do Rio de Janeiro, que assinala afastamentos, licenças e readaptaçôes de professores por disfonias, na ordem de $2 \%$ dos ativos.
} 
Cabe, aqui, considerar que essa "necessidade" de prevenção nem sempre é valorizada pela categoria docente e, muitas vezes, tem se mostrado mais uma insistência, por parte dos fonoaudiólogos, do que uma demanda por parte dos professores (FERREIRA, 1999-a).

Para DRAGONE (2000), a maioria dos projetos em saúde vocal que constam na literatura fonoaudiológica visam, num curto espaço de tempo (por meio de palestras, triagens e avaliações de voz e encaminhamentos) desenvolver instrumentos para que o professor adquira conhecimento sobre a produção vocal; sobre como lidar com a psicodinâmica vocal em classe e sobre a definição, etiologia, prevenção, identificação e tratamento dos principais problemas e doenças vocais. No entanto, segundo a autora, tais projetos não exploram devidamente a dinâmica da sala de aula e a rede de intercorrências e de ações pedagógicas que nela se inscrevem. Autores como MATTISKE, OATES e GREENWOOD, (1998) e SMITH et al. (1998) alertam para a necessidade de pesquisas que possibilitem outros dados sobre o cotidiano do trabalho docente e novos olhares sobre a problemática da saúde vocal docente, os quais permitam redirecionar as ações dos projetos de saúde vocal buscando sua maior efetividade.

As orientações e os procedimentos realizados nas ações de saúde vocal foram subsidiados pelo referencial da prática clínica em terapia de voz e por estudos que buscaram relacionar fatores ambientais das condições de trabalho dos professores e fatores comportamentais que podem influenciar o desenvolvimento de alterações vocais e disfonias (OLIVEIRA, 1995; THOMÉ DE SOUZA e FERREIRA, 1998 e 2000-a). Segundo a tendência histórica no campo da saúde pública e coletiva, tais ações seguiam a tradicional dimensão normativa, homogeneizadora e prescritiva de condutas e comportamentos individuais e que desconsidera a multiplicidade do social na produção de diferenças (MENDES, 1999).

Observa-se que a maioria dos estudos da área fonoaudiológica apontam fatores individuais de abuso ou mau uso vocal e diversos fatores do ambiente escolar, como de risco para alterações vocais, como acústica inadequada, ambiente ruidoso, presença de poeira e pó de giz, grande número de alunos por sala, dentre outros.

A identificação dos fatores de risco para a saúde vocal do professor encontra-se, também, na determinação generalizada de uma série de hábitos e condutas relacionados ao estilo de vida e ao uso da voz, orientados como parte de um programa de "higiene vocal", "exercícios vocais" e "cuidados com a saúde vocal". Exemplificam-se, para tanto, as orientações de apagar a lousa com pano úmido, de fazer higiene nasal com soro, beber 
determinada quantidade de água por dia, não pigarrear, não gritar nem realizar competição sonora, não comer alimentos gordurosos, que recaem sobre o profissional enquanto responsabilidade individual no controle dos "comportamentos de risco" para sua saúde vocal.

FERREIRA (1999-a), a respeito desse enfoque individualizante, apresenta breve retrospectiva histórica das ações fonoaudiológicas em saúde vocal do professor, na qual destaca que, na década de 60 , os professores e suas necessidades vocais não eram vistos no contexto de suas atividades profissionais ou da categoria docente, mas sim na especificidade do distúrbio vocal localizado no indivíduo, freqüentemente "culpado" pela sua alteração vocal, por ter gritado, falado muito, fumado ou "infringido" qualquer outra norma da chamada "higiene vocal".

Dessa maneira, a maioria das intervenções fonoaudiológicas em saúde vocal partiam do pressuposto do desconhecimento e da desinformação do professor em relação aos assuntos da área de voz e, em conseqüência disso, as ações educativas e preventivas pautavam-se por um caráter informativo e evidenciavam a tendência ao estabelecimento de relações de causa-efeito. Num discurso revestido de autoridade científica que propende à generalização de informações sobre a produção vocal ideal - na maioria das vezes distante da experiência cotidiana das pessoas a quem se dirigem e com resultados insuficientes e apenas parciais - prescreviam normas para exercícios e práticas de estilo de vida e normas de higiene vocal. produção vocal ideal.

Algumas autoras, como FERREIRA (1999-a e 1999-b) e GRILLO (2001), chegam a questionar o fato de que tais ações, assim caracterizadas, assumem um caráter mais de informação que do que de transformação. Em vista disso, é importante e necessário avançar, a partir desse enfoque, no sentido de melhor conhecer os aspectos que interferem e se relacionam com a saúde vocal do professor.

No entanto, o que se observa ainda hoje, na maioria das ações de saúde vocal coletiva direcionadas a professores, é a permanência desse enfoque normatizador de hábitos e comportamentos referentes ao estilo de vida, que atribui ao indivíduo a responsabilidade pelo seu processo saúde-doença vocal. Sem desmerecer a importância e a validade da atenção ao ambiente físico e das orientações, cuidados e exercícios vocais individualizados, é preciso refletir sobre o foco que vem sendo dado pela Fonoaudiologia nas ações envolvendo a saúde vocal de trabalhadores, no sentido de buscar ampliar a percepção e análise dos determinantes 
do processo saúde-doença desses sujeitos, de maneira a incorporar aspectos ainda desconhecidos ou que vêm sendo despercebidos ou subestimados.

Além dos fatores relativos à maneira pela qual as ações de saúde vocal do professor vêm sendo idealizadas e realizadas, outras dificuldades são sentidas e relatadas por diversos autores e referem-se, em geral, ao desinteresse e à falta de preocupação dos professores em relação à sua voz enquanto saúde vocal. Tal atitude leva à falta de cuidados com a voz, à demora e resistência para buscar o atendimento especializado, à falta de empenho junto às propostas de atendimento e até mesmo aos abandonos e desistências dos tratamentos propostos (PORDEUS, PALMEIRA e PINTO, 1996; FERREIRA, 1999; OLIVEIRA, 1999; DRAGONE, 2000; GRILLO, 2001 e CARELLI, 2002).

Para DRAGONE (2000), muitas vezes os professores não se dão conta do início do seu problema vocal e continuam ministrando suas aulas até que a voz venha a falhar drasticamente. No entanto, as causas desse aparente descaso dos professores com a própria saúde vocal não costumam ser abordadas na literatura. A autora acrescenta que um dos aspectos que contribuem para o desinteresse e apatia dos professores em relação à sua voz, o distanciamento entre a valoração e importância atribuídas à voz, por fonoaudiólogos e professores/pesquisadores da educação. Segundo ela, nas ações de saúde vocal com o professor, o fonoaudiólogo está direcionado para a voz/problemas de voz (enfoque sobre a doença e sua prevenção); enquanto que, na área de educação, são as atitudes e os comportamentos do professor que constituem o foco temático, deixando à margem as questões de saúde e de doença. Sugere uma mudança de foco nas ações de saúde vocal do professor, como uma maneira de estabelecer as interfaces entre a Fonoaudiologia e a Educação: tratar a voz como um dos componentes dos recursos didáticos e da interação professor-aluno.

PORDEUS, PALMEIRA e PINTO (1996) apontam, como hipóteses explicativas para o desinteresse dos professores, a falta de conhecimento, de informação e de orientação sobre condutas vocais desviadas, a falta de disponibilidade para o tratamento, as dificuldades financeiras, a falta de atenção da comunidade escolar, a deficiência dos cursos de formação de professores e a insuficiente atuação preventiva do fonoaudiólogo.

CARNEIRO (2000) evidenciou que o fato de o professor ter que pagar pelos serviços particulares de Fonoaudiologia com seus próprios recursos configura-se um impedimento para a procura do atendimento; então, justificando-se pelos seus baixos salários, os professores 
optam por pouparem a voz a investirem em um tratamento. Entretanto, cabe aqui considerar que, mesmo frente às facilidades oferecidas por convênios, cooperativas fonoaudiológicas e serviços públicos gratuitos, o professor demora ou reluta em procurar o atendimento.

GRILLO (2001) atribui o desinteresse dos professores ao contexto cultural de uma sociedade que desvaloriza a prevenção e que desloca a responsabilidade dos cuidados com a saúde para os órgãos e instituições governamentais e planos de saúde. Aos fonoaudiólogos, a autora sugere redimensionar o olhar, acostumado à prática clínica, para aprender a trabalhar com sujeitos sadios, aqueles em que a voz possa ser considerada no contexto e dinâmica de seu uso profissional.

Gradativamente vem aumentando o número de estudos que buscam deslocar o eixo patologia/tratamento para saúde/promoção da voz do professor. Essa perspectiva implica mudar a visão do que se traduz em deficitário para possibilidades, considerando os modos pelos quais o professor se relaciona com sua voz em seu cotidiano. Assumem, tais trabalhos, uma visão integral do sujeito e sua inserção social, ou seja, levando em conta os aspectos relacionais, culturais, sociais, do trabalho, da historicidade e da subjetividade na produção vocal no espaço escolar. Nessa perspectiva, podem ser mencionados os estudos de FERREIRA (1994 e 2000); FERREIRA, ALGODOAL e SILVA (1997/1998); SIMÃO e CHUN (1997); PENTEADO e BICUDO-PEREIRA (1999); SERVILHA (2000); DRAGONE (2000 e 2001) e CHUN (2001b).

No entanto, são raras, ainda, as produções que estabelecem relações entre voz e qualidade de vida, como as de ABBUD (2001), BEHLAU (2001) e DIAS e HARA (2001), mas que estejam voltadas especificamente para o professor.

Para conhecer o impacto da disfonia no dia-a-dia de professores de escolas pública e privada, ABBUD (2001) valeu-se dos questionários Health Survery (SF-36) e Voice Handcap Index (VHI) e observou que a saúde geral do sujeito influencia sua saúde vocal e vive-versa, concluindo que a disfonia afeta a vida social do sujeito causando impacto significativo em sua qualidade de vida. A autora sugere a utilização destes questionários como instrumentos no levantamento da saúde geral e vocal e também do impacto da disfonia em relação à saúde e qualidade de vida.

BEHLAU (2001) traduziu e adaptou para o português um questionário para a mensuração de qualidade de vida relacionada à voz (QVV), com objetivo de verificar o 
impacto dos problemas de voz sobre as atividades diárias e a vida dos profissionais, levando-se em conta a severidade e frequêencia do problema, baseado na própria percepção dos indivíduos. A pesquisa abrange dois domínios: fisico e sócio-emocional e focaliza, principalmente, a relação indivíduo/voz em algumas possibilidades de uso da voz no cotidiano. A autora concluiu, dentre outros aspectos, que as mulheres sofrem mais com a disfonia que os homens, uma vez que o impacto da disfonia foi pior e maior sobre a qualidade de vida de mulheres. $O$ estudo demonstrou uma relação positiva entre a auto-avaliação no QVV e a qualidade vocal das pessoas, o que indica que o questionário pode ser considerado como um instrumento confiável para a investigação das relações entre qualidade de vida e voz, a ser utilizado tanto em pesquisas como na prática clínica diária.

PENTEADO e BICUDO-PEREIRA (1999) e FERREIRA (1999-a) abordam diversos aspectos da qualidade de vida e do trabalho de professores, que se configuram como predisponentes, agravantes e conseqüentes das disfonias. Consideram aspectos como: a demanda vocal; os usos da voz; as inadaptações vocais; a sobrecarga de trabalho e o estresse cotidiano; as questões de ordem emocional; os relacionamentos interpessoais; os fatores ambientais (ruído, umidade, alergenos, número de alunos e localização da sala de aula); as questões de gênero e dos papéis ocupados pelos sujeitos na sociedade; a postura e as doenças fisicas (problemas digestivos, refluxo, gripes e infecções das vias respiratórias), dentre outros.

No Brasil, na área de saúde do trabalhador, a literatura que relaciona processo de trabalho docente e-saúde dos trabalhadores é ainda incipiente, embora, como apontam SILVANY NETO et al. (1998), seja de extrema relevância o estudo das condições de saúde e trabalho do professorado.

Há, ainda, poucos estudos voltados ao professor nessa ótica, ou seja, de um sujeito que sofre e adoece em seu trabalho e que, muitas vezes, não busca e/ou não encontra possibilidades de mudanças ou de melhoria das suas condições. Assim, o professor ignora e subestima as suas próprias necessidades de saúde e assume uma posição desanimada, queixosa, fatalista, conformista e derrotista, que o conduz à passividade e à paralisação - quando, conforme PERES (2000), o sentido maior de sua ação social, o seu objetivo, seria construir. E, aqui, cabe referenciar BARDOU DE CARVALHO, (1995), para quem o professor se encontra aquém do processo transformador, em relação às condições de vida, saúde, trabalho e qualidade de vida, o qual a escola se propõe a instaurar. Tais aspectos justificam a necessidade de 
intervenções de promoção da saúde do professor trabalhador pois, como indica CARNEIRO (2000), recentemente vêm sendo realizados alguns estudos sobre a vida dos professores, porém poucos estabelecem relações com as questões de saúde e trabalho.

A proposta de Escolas Promotoras de Saúde relaciona-se com a qualidade de vida da comunidade escolar e isso implica considerar a escola também como um ambiente de trabalho, no qual o trabalhador professor desponta como um sujeito central num processo que se propõe a promover a saúde de toda a comunidade escolar. Então, há que se focalizar a atenção nesse sujeito/trabalhador e nos processos saúde-doença que lhe dizem respeito - em especial a saúde vocal - lembrando que a voz deve ser pensada em relação à saúde geral da pessoa (SILVA, 1998).

Já a presente pesquisa se insere na perspectiva de integrar as questões de saúde, trabalho, subjetividade e qualidade de vida na compreensão das questões de voz/saúde vocal do professor, tendo como referência as dimensões subjetivas e sócio-culturais da voz/saúde vocal e a concepção de professor como sujeito social e trabalhador. Neste sentido, busco referenciais teóricos interdisciplinares dos campos da Saúde do Trabalhador, da Educação, da Saúde Pública/Coletiva, da Fonoaudiologia, da Semiologia e da Psicologia.

A pertinência dessa pesquisa, no presente momento da realidade brasileira, encontra ressonância histórica com dados e fatos, além dos recentes esforços e investimentos da área fonoaudiológica em diversos campos de interesse da saúde vocal coletiva, dentre os quais podem ser destacados:

- A Fonoaudiologia, segundo OLIVEIRA (1999), uma das áreas de atuação de maior destaque e que mais prometem projetar-se nos próximos.anos no trabalho com a voz. Durante a década de 90 , no Brasil, muito se avançou nos estudos desta área, especialmente na clínica de voz, com os recursos tecnológicos, diagnósticos e terapêuticos. Entretanto, na área preventivo/comunitária, nas questões de promoção da saúde vocal, a prática fonoaudiológica pouco se modificou. 
- As áreas da Fonoaudiologia e Otorrinolaringologia - em parceria com diversas entidades, associações e setores da sociedade - unindo esforços para dar visibilidade nacional às questões de saúde vocal, vêm realizando anualmente, desde 1999, as Campanhas Nacionais da Voz e comemorações da Semana e "Dia da Voz", com objetivos de prevenção e de promoção da saúde vocal (CRFA $2^{\mathrm{a}}$ Região, 2001-a).

- Um fato de grande importância para a Fonoaudiologia, Educação e Saúde Pública/Coletiva é que a Assembléia Legislativa de São Paulo aprovou, em 28/09/2001, a Lei n 10.893, que dispõe sobre a criação de um Programa Estadual de Saúde Vocal do Professor da Rede Estadual de Ensino e que sugere ações preventivas por meio de um convênio entre as Secretarias de Educação e da Saúde. O Projeto prevê a realização de, no mínimo, um curso teórico-prático anual para professores (CFFA 2001 e CRFA $2^{a}$ Região, 2001-d). Na cidade de Santos (SP) foi sancionada a Lei $n^{\circ} 2058 / 02$ que inclui um Programa de Saúde da Comunicação no planejamento escolar municipal. Tal programa, com objetivos preventivos, constará, dentre outras coisas, de orientações, cursos e palestras a professores a serem realizadas no início de cada ano letivo com assessoria aos professores no decorrer do ano e uma avaliação a cada final de ano (CRFA 2003).

- A realização anual desde 1997, na Pontificia Universidade Católica de São Paulo/PUC/SP, dos Seminários de Voz Profissional, tendo como tema a discussão da disfonia como doença do trabalho, unindo profissionais de diversas áreas como a Fonoaudiologia, Otorrinolaringologia, Medicina do Trabalho e Psicologia, no sentido de eleger prioridades de pesquisa e de ação - dentre as quais pode ser citada a decisão de "continuar as pesquisas (...) buscando trazer mais dados sobre a qualidade de vida e impacto da disfonia no dia-a-dia de diferentes profissionais, com o intuito de subsidiarem novas discussões" (FERREIRA, 2002; p. 18). 
- O relatório final da $1^{2}$ Reunião Pró-consenso Nacional sobre Voz Profissional, realizada no Rio de Janeiro, em abril de 2001, propondo a ampliação dos serviços e programas de educação, tratamento, capacitação e aperfeiçoamento vocal àqueles que fazem o uso profissional da voz (VOX BRASILIS, 2001).

- As propostas de Escolas Saudáveis ou Escolas Promotoras de Saúde começam a ser implantadas no Brasil e, nesse cenário, são pertinentes e necessários os estudos focalizados no professor enquanto sujeito, trabalhador e ator social no contexto de uma Escola Promotora de Saúde uma vez que, além de um parceiro e mediador importantíssimo na formação de ambientes saudáveis, ele também é merecedor de cuidados e ações de saúde que respondam às suas necessidades específicas - ainda que estudos como o de PENTEADO et al. (2002) demonstrem que o professor tem sido preterido enquanto alvo das ações destas propostas.

Os fatos recentes vêm concretizar, ao menos em parte, o que propunham SCALCO, PIMENTEL e PILZ (1996), no sentido de que a questão da saúde vocal do professor seja tirada do silêncio da comunidade escolar para ser discutida, não apenas por médicos e fonoaudiólogos, mas também numa instância pública e social. Assim, é na perspectiva de que o tema da saúde vocal entre para a pauta das discussões de coletividades - em especial da categoria docente - e, inclusive, perante a garantia legal e a possibilidade de inserir, no planejamento escolar, ações coletivas de promoção da saúde vocal de professores de característica processual e não pontual, que essa pesquisa se inscreve num momento propício e fecundo, para se aprofundar a reflexão sobre o processo saúde-doença vocal docente sob uma ótica mais ampla e abrangente de voz, de sujeito e de saúde.

É impossível dissociar a problemática vocal dos professores, de outras problemáticas presentes no contexto do trabalho docente, pois a situação vocal pode ser decorrente de outros conflitos enfrentados pelo professor (DRAGONE, 2000).

Há aspectos inerentes à qualidade de vida e ao cotidiano do professor que merecem ser conhecidos e melhor investigados. É preciso dar visibilidade às condições e à organização do trabalho docente, nas maneiras pelas quais o professor as percebe e interpreta, considerando-se 
suas possíveis relações com as questões do uso profissional da voz e de sua saúde vocal. Importam, também, aspectos da subjetividade do sujeito-trabalhador-professor, merecendo ser conhecidos e investigados enquanto percepções, interpretações, representações, relações, significações, usos e funções por ele atribuídos à sua voz nas especificidades dos posicionamentos assumidos nos diversos processos de interação social.

E são destes aspectos que me ocupo nesta pesquisa - especialmente no que eles interferem no cuidado e interesse do professor com a sua voz e que se traduzem em possibilidades e/ou dificuldades para a promoção da saúde vocal docente. Interessa buscar subsídios e possibilidades para a atenção, compreensão e intervenção mais ampla, abrangente e efetiva da Fonoaudiologia, na Promoção da saúde vocal do trabalhador professor.

É possivel encontrar outras explicações para o fato de o professor demorar tanto para buscar ajuda especializada frente suas necessidades de saúde vocal e, assim, não cuidar de sua voz e não se envolver efetivamente nas ações fonoaudiológicas de saúde vocal. Poder-se-ão, também, vislumbrar caminhos que permitam superar a idéia tradicional de "falta de interesse", "carência de informação" e simples "desconhecimento" e buscar os aspectos determinantes e intervenientes do processo saúde-doença docente, de maneira a contribuir para uma ampliação do foco de atenção e das possibilidades da ação fonoaudiológica na promoção da saúde vocal coletiva.

Neste estudo, viso, mais do que citar aspectos intervenientes, contribuir para o conhecimento cuidadoso e a interpretação das necessidades especificas e condições de vida e trabalho do professor, subsidiando movimentos reflexivos que cooperem para incrementar, qualitativamente, as ações coletivas, as propostas educativas e a práxis fonoaudiológica na promoção da saúde vocal desse trabalhador, especialmente quando elas se referem a processos educativos nos quais os professores se possam fazer sujeitos ativos.

Espero, assim, poder contribuir para a construção e ampliação do eixo de compreensão e análise das ações educativas em saúde coletiva e projetos fonoaudiológicos de saúde vocal especialmente aqueles que, numa perspectiva mais ampla, sejam traduzidos em possibilidades para a discussão e transformação da qualidade de vida (COCCO, 1999-a e COCCO, 1999-b) -, sejam eles voltados para a promoção da saúde do trabalhador; para os projetos no cumprimento da lei de saúde vocal do professor; para as ações no contexto de formação de Escolas Promotoras de Saúde ou para a prática de assessoria fonoaudiológica de profissionais da voz, 
sem esquecer dos desdobramentos para a prática clínica/terapêutica na área de voz, especialmente com os professores disfồnicos.

Nesse contexto, a presente pesquisa tem como objetivo geral investigar as relações entre qualidade de vida e voz/saúde vocal do professor. No primeiro capítulo, intitulado $O$ professor, seu trabalho, sua vida e processo saúdeldoença, discorro sobre vários aspectos do ser professor(a), englobando características do trabalho docente e da vida cotidiana do(a) trabalhador(a) professor(a), aspectos tradicionalmente omitidos ou pouco abordados na maioria dos estudos em saúde vocal dessa categoria profissional e que, no entanto, se configuram os lugares onde o processo saúde-doença docente é criado, significado e representado. Ao final do primeiro capítulo teço algumas considerações e apontamentos acerca de perspectivas de investigação em saúde vocal docente. No segundo capítulo apresento os objetivos gerais e específicos deste estudo e no terceiro capítulo a metodologia adotada e o delineamento da pesquisa, com suas fases de planejamento e de levantamento de dados. No quarto capítulo apresento os resultados e discussão e o último capítulo refere-se às considerações finais. 


\section{CAPÍTULO 1}

\section{O PROFESSOR, SEU TRABALHO, SUA VIDA E PROCESSU SAÚDE/DOENÇA}

Neste capítulo abordo, com apoio na literatura, alguns aspectos do ser professor, das caracterỉsticas do trabalho docente e da vida cotidiana do trabalhador professor, nas possiveis relações com o processo saủde-doença docente, apresentando consỉderações e perspectivas de investigaçả̉o em saủde vocal, a partir das questổes referentes às seguintes temáticas:

1) Ser professor - amor e dor do trabalho docente;

2) Ser mulher professora - questồes de gënero, subjetividade e vida privada;

3) A relaçầo professor-alunos - autoridade e a questầo da indisciplina

4) Processo saủde-doença de trabalhadores professores;

5) Licenças de saúde, adesã̀o e resistência no trabalho docente;

6) Perspectivas para a investigaçẫo da saủde (vocal) do trabalhador professor.

\section{1) SER PROFESSOR - AMOR E DOR DO TRABALHO DOCENTE}

Diversos aspectos articulam-se na produçắo do prazer/sofrimento no trabalho docente.

Ser professor é ser histỏrico, pois cada palavra e cada gesto seu carrega sentidos e insere-se num contexto maior que o liga ao destino dos homens, transcendendo a ele e à sua exỉstềncia; educar é um ato mảgico e sỉngelo de realizar sínteses e construír laços entre passado e futuro - ensinar o que foi para inventar e re-significar o que será; daí que o professor 
pode ser considerado um artífice de novos mundos (CODO e VASQUES-MENEZES, 2000a).

O exercício da docência não é estático nem permanente, mas processual, mudança, movimento e arte; são novas caras, novas experiências, novo contexto, novo tempo, novo lugar, novas informações, novos sentimentos, novas interações, novos desafios (CUNHA, 1999).

Ao contrário de outras funções/profissões, o trabalho docente é considerado inalienável pois, ao trabalhar, o professor se apropria do conhecimento relacionado ao trabalho e não há como expropriar tal conhecimento; assim, na sala de aula o professor é o artífice, é o autor que assina a obra que o aluno vai carregar, obra essa que não se deteriora, só acrescenta e se enriquece, seja no aluno ou no próprio professor (CODO e BATISTA, 2000; CODO e VASQUES-MENEZES, 2000-a; SORATTO e OLIVIER-HECKLER, 2000-b).

O trabalho do professor é desafiador, pois explora as potencialidades e estimula o desenvolvimento pessoal e profissional do professor, levando-o a descobrir coisas novas e a ver mudanças na sua pessoa, o que o motiva a buscar sempre mais e a fazer mais e melhor. A possibilidade ver o que se faz para o outro, pelo outro e também por si mesmo, somada a essa chance de fazer a história com as próprias mãos, dá ao professor a sensação de ser sujeito ativo, vivo, participante efetivo do mundo em que vive e se torna fonte de satisfação para esse trabalhador, a ponto de que, muitas vezes, tal satisfação acaba se sobrepondo à recompensa social ou financeira.

Aqui, talvez, estejam algumas das razões pelas quais o trabalho acaba ganhando tanta importância na vida do sujeito, um dos fatores pelos quais o professor persiste em seu trabalho, apesar das inúmeras dificuldades enfrentadas. Continuam atuando, dedicando-se, sentindo-se motivados, comprometidos e ainda satisfeitos numa atividade tão exigente e mal remunerada; suportando péssimas condições de trabalho, perdendo horas preciosas de sono, deixando ou até esquecendo de se alimentarem; doando-se cada vez mais e não medindo esforços para alcançarem seus objetivos, pela vontade de promover algo em prol do outro e de realizar-se na realização do sonho do outro (SORATTO e OLIVER-HECKLER, 2000-b; VASQUES-MENEZES e GAZZOTTI, 2000). Sim, nesse sentido há uma transcendência de tempo e lugar; pois o professor realiza-se na realização do sonho do aluno e continua realizando-se na realização dos sonhos dos seus ex-alunos. 
O trabalho docente é de alta complexidade e implica compromissos, buscas e dedicação constantes que continuam além da sala de aula. São estudos continuados, participação em cursos, reuniões e comissões; correções de provas, relatórios e trabalhos; preparação de materiais e aulas; pesquisa e produção literária; leitura de textos, dissertações, teses, livros, revistas e meios de informação eletrônicos; atendimento a alunos e/ou seus familiares, sem ter acréscimo ou compensação financeira alguma e nem mesmo reconhecimento social por isso tudo. Nesse contexto, o professor não pode ao menos ficar triste ou deixar-se abater, pois dele é esperado que se mantenha sempre disponível e alegre, uma vez que sua capacidade de empatia é imprescindível para a qualidade do processo ensinoaprendizagem (SORATTO e OLIVER-HECKLER, 2000-a e 2000-b).

Além da complexidade, a carga de trabalho docente vem aumentando e sendo mudada em sua natureza e isso conduz o professor a assumir tarefas administrativas, de supervisão, de assessoramento e de orientação, bem como a enfrentar problemas sociais variados (O.I.T., 1991) que repercutem em responsabilidades difusas e papéis secundários, junto às necessidades que atingem a comunidade escolar e seu entorno. $\mathrm{O}$ professor é levado a lidar com a violência doméstica, escolar e urbana, o desemprego, a fome, o abandono, a educação sexual, o uso e tráfico de drogas, a falta de assistência médica e a insuficiência dos serviços de saúde, o estupro, a gravidez na adolescência, a prostituição, o trabalho infantil, a inclusão de sujeitos com necessidades especiais, as mudanças de valores na sociedade, dentre outras questões com as quais ele se depara sem estar devidamente preparado ou assessorado.

Esses desdobramentos do papel do educador lhes configuram verdadeiros desafios que contribuem para sua exposição social e envolvimento em situações de conflitos e tensões, sobrecarregando-o e deixando-o susceptível ao desgaste, ao sofrimento e a diversos problemas de saúde que repercutem negativamente sobre si e sobre as pessoas com as quais ele se relaciona em seus contextos sociais cotidianos (O.I.T., 1991 e FIGUEIRA, 2001).

Conquanto aumentem e se desdobrem as responsabilidades sociais e do papel do professor, observa-se uma desqualificação e desvalorização da função e do trabalho docente na sociedade, que repercute na degradação da qualidade de vida e do prestígio social dessa categoria de trabalhadores. Alguns autores apontam fatores como a reestruturação produtiva neoliberal e a massificação do ensino e da subordinação à racionalidade técnica, em que a escola vai, aos poucos, assumindo características de uma empresa, na qual a organização do 
trabalho se dá mediante a separação entre a concepção e planejamento da tarefa, as funções administrativo-burocráticas, e a sua execução (BARDOU DE CARVALHO, 1995; CUNHA, 1999 e ROCHA, GUSTAVO e GOMES, 2001). Autores como COELHO (1998) observam que, para o ensino em geral, não tem sido exigido um bom preparo intelectual dos educadores; tem se mostrado "suficiente" uma formação rápida e precária, preocupada principalmente com métodos, técnicas e definição de objetivos a serem atingidos em sala de aula.

Assim, na rigidez da estrutura de funcionamento escolar explicitam-se processos de dominação, de exercício de poder e de exploração, que estão na origem da tecnocracia e do autoritarismo em educação, o que reduz o professor à condição de mero executor de decisões, programas, métodos e técnicas previamente definidos, e que o mantêm alheio aos mecanismos de produção da educação e do sistema educacional, afastado das principais tomadas de decisões relativas à escola (O.I.T.,1991; BARDOU DE CARVALHO, 1995; COELHO, 1998 e BETANCOURT e PALACIOS, 1999; CUNHA 1999 e ROCHA, GUSTAVO e GOMES, 2001).

O conjunto desse quadro de precarização e degradação, a que o sistema educacional (especialmente o público) tem sido levado, revela-se no abandono das escolas; na falta de materiais e de manutenção de suas edificações, instalações e equipamentos; na insegurança no trabalho, em que os professores são desrespeitados e ameaçados por alunos e seus familiares; nas situações violentas como invasões, vandalismos, depredações, assassinatos e explosão de bombas que ocorrem na escola; no rebaixamento salarial; na piora das condições de trabalho e nos problemas de saúde dos professores - que se encontram esgotados, estressados e com diversos sintomas físicos, incluindo-se os problemas vocais (BRITO, 2000 e ISTO É, 2002).

Vale lembrar que, muitas vezes, perante a sociedade, a docência é desqualificada a ponto de ser descaracterizada até mesmo em sua condição de trabalho. O professor é desconsiderado enquanto trabalhador e profissional; e a representacão dessa desqualificação social do trabalho docente pode ser exemplificada no enfrentamento da constrangedora pergunta, feita por familiares, conhecidos, alunos ou pais de alunos a tantos professores e professoras: "você trabalha ou só dá aulas?" ou "você é só professor ou trabalha em algum lugar?" - como se a docência não tivesse, ela própria, o status de trabalho ou de profissão; como se a condição da docência, de ser professor, ocupasse, no imaginário popular, o lugar de uma atividade paralela, de menor importância, um "bico". Isso contribui para um processo de 
deterioração da auto-estima dos trabalhadores professores que, deixam de lutar pela transformação do ensino - inclusive enquanto processo de trabalho que influencia seu modo de vida, sua própria saúde e sua identidade (BARDOU DE CARVALHO, 1995 e BETANCOURT e PALACIOS, 1999).

Para COELHO (1998), uma possibilidade transformadora do trabalho pedagógico em responsabilidade coletiva, com valorização dos educadores e demais sujeitos envolvidos no processo de ensino, encontra-se, por exemplo, na superação da separação entre planejamento e execução e num rodizio dos educadores pelas diversas funções e vários momentos do processo de trabalho docente. Autores como ARROYO et al. (1998) propõem estilos coletivos e participativos nas supervisões educacionais, tendo como referência a realidade, os problemas da comunidade e a vivência do aluno e dos professores. Nessa perspectiva é que esses autores visualizam possibilidades de organização coletiva da categoria docente, de formação de uma escola democrática, de construção de uma educação libertadora e de luta pelos reais interesses de classe e da comunidade dos sujeitos/professores.

Observa-se, mais recentemente, uma tendência de revalorização da educação, às custas da emergência de novas tecnologias que alteram conteúdo, forma e organização do trabalho; entretanto, há que se considerar que, dependendo da maneira como tais inovações chegam e são apresentados ao professor - por vezes sem o devido preparo e sem maiores oportunidades de discussão e reflexão - acabam demandando tanta energia para as adaptações e transformações necessárias, que resultam em desgastes e em comprometimento da saúde do professor (BRITO, 2000).

Característica importante do trabalho docente é que ele se desenvolve no contexto das relações sociais, espaço de cultura mediado pela linguagem e pela intersubjetividade ${ }^{1}$. No ato educativo, entram em questão a dinâmica do jogo intersubjetivo das interações, a significação, a afetividade e todo um campo de lutas, de conflitos, de interesses e de poder que, ao mesmo tempo em que são incorporados pelo ato educativo, são dele regentes (CUNHA, 1999). E a voz se faz presente nesse jogo de relações (MARTZ, 1987 e SERVILHA, 2000), sendo a qualidade vocal do professor fundamental na construção de elos de afetividade na relação professor-alunos (DRAGONE , 2000).

\footnotetext{
${ }^{1}$ Segundo KUPFER (1982), enfoque intersubjetivo significa considerar que não preexistem entidades que interagem/interatuam; mas sim que os sujeitos se constituem como entidades no processo mesmo da relação.
} 
Mas as relações de ensino não nascem nem se esgotam nos limites da sala de aula ou nos limites da interação professor-aluno (FONTANA, 2000). Há uma rede de relações sociais e de afetos possíveis que se coloca face ao professor, a cada vínculo que se forma na escola ou fora dela, a cada contato com os alunos, com as famílias e demais profissionais da escola, num trabalho iniciado e completado numa relação estritamente social, permeada e carregada da história e das subjetividades. Cabe dizer que, em se tratando de relações sociais na escola, importa a violência explícita ou velada do poder da norma, das regras, do controle, dos disciplinamentos, das hierarquias institucionais, dos silenciamentos, da solidão e dos desafetos.

Tais fatores se materializam nas condições e relações de trabalho, na organização do trabalho docente, no sentido e no valor que sujeito e seu trabalho representam para si, para a comunidade escolar e para a sociedade. Também importa a interpretação que ele faz do seu papel profissional e das maneiras como se aproxima ou se distancia desse papel, dentre outros fatores que pesam na constituição da identidade, da subjetividade e do modo de ser moral enquanto trabalhador, desencadeando vivências e sentimentos de prazer ou de sofrimento relacionados ao trabalho e à própria pessoa e, muitas vezes, dizimando a identidade, o trabalho e a vida do professor (ROSA, 1991 e 1994; CODO e VASQUES-MENEZES, 2000-a; SORATTO e OLIVIER-HECKLER, 2000-b e VASQUES-MENEZES e GAZZOTTI, 2000).

Compreender a ação desses aspectos relacionais, sociais, culturais e subjetivos na determinação do processo saúde-doença do professor constitui passo fundamental para se avançar, a partir dos modelos tradicionais nas questões de saúde do trabalhador, de maneira a superar abordagens parciais tais como:

a) a abordagem biologicista da concepção de causalidade, que vincula a doença a um agente específico;

b) a abordagem de identificação, proteção e controle dos fatores de risco do ambiente de trabalho que conta com medidas de proteção dos trabalhadores;

c) a abordagem individualizante, que focaliza a atenção (e a sanção) sobre o trabalhador (a vítima) - ao invés de concentrá-las nas circunstâncias e nos problemas - responsabilizando e culpando o trabalhador pelos seus problemas de saúde e por ele não ter adotado as modificações necessárias em seus desempenhos. 
Chama-se a tal processo “culpabilização da vítima”, processo esse contrário à filosofia da promoção da saúde (BERLINGUER, 1993; MENDES e DIAS, 1999; ARAÚJO, 2001; BRANT e BARROS DE MELO, 2001 e RESTREPO, 2001).

No trabalho, as relações de produção e de poder têm como objeto o corpo do trabalhador, cujas forças deverão ser organizadas, submetidas e direcionadas por processos de disciplinamento, controle, obediência, docilidade e assujeitamento (que envolvem, inclusive, uma manipulação calculada dos elementos corporais, dos seus gestos e comportamentos), para a produção do caráter "utilitário" e do modo de ser moral do trabalhador - com implicações sobre a constituição da subjetividade como pessoa e trabalhador (ROSA, 1994; FOULCAULT, 1995 e NAKAMURA, 1997). Assim, o corpo do trabalhador passa, numa sociedade que impõe aos sujeitos uma lógica de administração do tempo do trabalho e do lazer, a ser alvo de determinados cuidados, preocupações, recomendações correções e adaptações, impostos ininterruptamente a ponto de sobrepujar e afetar a espontaneidade, a sensibilidade e o prazer.

Em suma, os sujeitos não podem estar displicentemente no mundo; seus corpos - e, aqui, acrescentamos, seus gestos e comportamentos corporais e vocais - "devem ser exercitados, firmemente corrigidos, complementados em suas insuficiências e incitados a obter prazer deste processo" (NAKAMURA, 1997; p.89) em que importam os objetivos do trabalho, em detrimento dos interesses pessoais, dos afetos e expressões dos sujeitos. Há, segundo essa autora, uma cultura que contribui para a redução, distorção e deformação do sensível/da sensibilidade humana, bem como das interpretações e das significações a ela atribuídas; para uma des-sensibilização que implica, também, as maneiras de perceber, de sentir e de enfrentar o sofrimento, uma vez que "muitos indivíduos não se sentem sofrendo ao realizar determinadas atividades, pois elas são tidas como condizentes com seus projetos de vida e apropriadas às exigências da modernidade" (p. 75).

Nessa perspectiva, em se tratando do trabalhador docente, sendo a linguagem oral, a voz, o seu instrumento e ferramenta de seu trabalho, deverá ser explorada nos seus potenciais funcionais, utilitários e produtivos, especialmente naquilo que configura o recurso didático e de controle da classe e elo das relações interpessoais em sala de aula e, dessa forma, haverá de ser disciplinada, controlada e cuidada. 
Na prática docente, o referencial para o controle e disciplinamento da linguagem/voz é parte do conjunto de representações construídas, na área da Educação, acerca dos estereótipos de "bom" professor ou do professor "competente" os quais, ainda que implicitamente, normatizam, controlam e estabelecem os limites do que e como pode ou não ser feito ou dito em sala de aula e de como o professor deve ou não fazê-lo/dizê-lo. Concorrem, assim, representações de um professor dócil e amigo de seus alunos, ao mesmo tempo em que se espera que ele mantenha o controle e disciplina dos mesmos, imbuídos dos ideários de uma voz clara, agradável, expressiva, com ritmo compassado e sem elevar o volume ou gritar.

As representações envolvem, ainda, as relações hierárquicas dentro da escola e as expectativas acerca dessas relações, tendo em vista que o professor também se encontra na condição de empregado, subordinado, dirigido e coordenado por outros profissionais que ocupam cargos e funções hierárquicas a ele superiores. Assim é que o disciplinamento e a rigidez da estrutura escolar também recaem sobre ele em forma de normatizações, de controles variados que envolvem os horários, o cumprimento do planejamento pedagógico, as cobranças e a vigilância dos comportamentos, das atitudes e atividades desenvolvidas pelo docente (O.IT., 1991). - A tudo isso, espera-se do professor que responda com obediência e com docilidade!

$\mathrm{Na}$ Fonoaudiologia, no campo da saúde vocal docente, as referências para o controle e o disciplinamento dos gestos e usos da voz do professor podem ser representadas pelos esforços de orientações de "higiene vocal" (que implicam mudanças de hábitos, atitudes e estilo de vida do sujeito) e dos "treinamentos" vocais e das normatizações que recaem sobre os usos e os padrões vocais, distinguindo entre os aceitos ou adequados e aqueles tidos como "inadequados" e que, portanto, devam ser modificados ou mesmo evitados, na busca de uma produção "higiênica" da voz, de padrão e qualidade vocal freqüentemente idealizados.

Busco uma perspectiva mais abrangente das relações entre trabalho e processo saúdedoença, em que se considere que as situações sociais configuram cargas de trabalho que podem ter conseqüências negativas para a saúde do trabalhador; e que essas situações não devem ser entendidas como "risco" isolado simplesmente, mas cuja importância deve ser considerada na interação com o processo de trabalho e com as percepções dos trabalhadores (OLIVEIRA, 1995 e ARAÚJO, 2001). 
COHN e MARSIGLIA (1994) abordam as repercussões do processo de trabalho sobre a saủde do trabalhador, reportam-se a Dejours, e apresentam uma distinção entre condições de trabalho e organização do trabalho. Para essas autoras, as condições do trabalho dizem respeito às condições físicas, químicas, biológicas, dentre outras do ambiente de trabalho e que repercutem, principalmente, sobre a saúde física do trabalhador. A organização do trabalho diz respeito à divisão técnica e social do trabalho, à hierarquia entre os trabalhadores, ao controle das pausas, ritmo, tempo e execução do trabalho, ao padrão de sociabilidade e relações interpessoais, que repercutem principalmente sobre a saúde mental do trabalhador causando desgastes e sofrimentos psíquico e físico.

A organização do trabalho, segundo MENDES e MORRONE (2002), resulta do processo intersubjetivo, que envolve a interação de diferentes sujeitos, com história passada, presente e projetos futuros, numa dada realidade que implica a construção de relações sociais e a produção de significações de um coletivo de trabalho e da sua identidade social, ajustandose, ao mesmo tempo em que transformando a organização desse trabalho. Nessa perspectiva, importa conhecer e considerar o trabalho prescrito, o real, o percebido e a dinâmica de relações entre colegas e níveis hierárquicos (BETANCOURT e PALACIOS, 1999).

O trabalho prescrito é entendido como as expectativas, os tipos de controle, os ritmos, as normas, as regras, as crenças, as técnicas, as determinações, as formalidades hierárquicoadministrativo-institucionais impostas e as características que deve assumir a atividade docente, conforme idealizada pelo próprio professor, pelas equipes de educadores e definida nos projetos pedagógicos e documentos oficiais de educação.

Como trabalho real entende-se a ação, a maneira concreta como ele acontece, o que na prática foi possível realizar do trabalho prescrito, muitas vezes em descompasso ou contradição com tal tarefa - o que pode ser fonte de tensão, angústia ou estresse, dependendo de uma série de fatos, dentre os quais a maneira como o trabalhador percebe sua própria incumbência.

$\mathrm{E}$, na seqüência, o trabalho percebido refere-se às formas pelas quais o professor entende, interioriza, interpreta, representa e significa a função docente.

Diversos aspectos apresentam-se nesse universo de relações, sentimentos e significados que permeiam as diferenças entre trabalho prescrito, real e percebido, criando estratégias individuais e coletivas dos trabalhadores para garantir a produção e o 
enfrentamento das adversidades, das variabilidades, dos imprevistos e dos incidentes. As condições e a organização do trabalho do professor são por ele elaboradas ativa e contraditoriamente como submissão e rebeldia, anulação e preservação do corpo e da vontade, adesão e resistência ao trabalho, e cujas marcas e indícios dos embates dessas disparidades e diferenças podem passar despercebidas ou não. No entanto, de uma ou de outra forma, fazem parte do sofrimento dos professores, tornando-se visível nos problemas e doenças desse trabalhador (FONTANA, 2000; COLBARI, 2001 e HECKERT et al., 2001

Muitas vezes, os professores percebem essa disparidade e respondem de maneira queixosa, num lamento que exprime a sensação de dependência e impotência face aos problemas. Tal queixa parece minimizá-los, gerando, por um lado, um certo consolo e, por outro, um tipo de paralisia que imobiliza e impede a busca de soluções (LAPO, 2000). Outros autores, como PERES (2000), também sinalizam essa tomada de posição, por vezes desanimada, queixosa, fatalista, conformista e derrotista do professor, que mais conduz à passividade quando o maior sentido de sua ação social seria o de construir...

No campo da Fonoaudiologia, FERREIRA et al. (2002), pesquisando saúde vocal e saúde geral de professores, também encontraram a figura de um professor poliqueixoso em relação aos aspectos de saúde geral. É preciso, conforme propõe LAPO (2000), ultrapassar a queixa para dar espaço a perguntas, suportar o vazio momentâneo da ausência de respostas e evitar cair na facilidade das explicações rápidas que as queixas implicam para, a partir delas, refletir e analisar as situações que as geraram. Nesse sentido é que CARNEIRO (2000) considera que os professores não dispõem dessas oportunidades de tomada de consciência e de reflexão sobre a própria realidade, nem estão a elas habituados, em seu cotidiano.

Em suma, o trabalho é um espaço social de construção de identidades e de maneiras de ser e de estar na profissão e na comunidade/sociedade; é lugar onde se localizam importantes objetivos da vida; lugar de lutas e de conflitos que caracterizam a maneira como cada um se sente e se diz professor, num processo de apropriação de sentidos da sua história pessoal, profissional e social (NÓVOA, 1995; KOHEN, 1999 e SILVA FILHO, 2001) já que "cada homem constrói a sua própria história enquanto produz sua própria existência, através do trabalho" (PESSANHA, 1994; p.15), de maneira que as opções do professor entrecruzam a sua maneira de ser com a sua maneira de ensinar. Então, o professor é a pessoa, e uma parte 
importante dessa pessoa é o professor, de tal maneira que não é possível separar o eu pessoal do eu profissional.

O trabalho é, portanto, um núcleo fundamental e constitutivo de subjetividades e intersubjetividades que exerce efeitos sociais nos trabalhadores, em suas famílias e em toda a sociedade (LIMA, 2001). Por essa razão considero que os efeitos sociais do trabalho não incidem sobre o professor somente nos momentos em que ele está em sala de aula ou durante o tempo do trabalho, mas expandem-se também para o tempo vivido fora e além da sala de aula, nos modos de viver a vida privada (ASSUNÇÃO, 1996 e BETANCOURT e PALACIOS, 1999). Os modos de pensar, sentir e agir que se constituem nas experiências profissionais são transportados para o interior da vida familiar e comunitária do professor, de maneira que vida profissional e vida privada interagem e se afetam mutuamente no processo saúde-doença docente (NÓVOA, 1995).

Outro aspecto a ser considerado é o da estruturação do tempo de trabalho pois, em se tratando de uma jornada excessiva e de poucas pausas, a vida privada acaba sendo afetada, especialmente na redução do tempo e da qualidade do convívio familiar e social, e das atividades destinadas ao repouso, ao lazer e ao investimento pessoal do trabalhador (LIMA, 2001; BORGES, 2001 e ROTENBERG et al., 2001). Pode ocorrer falta de interesse e de vontade de participar de eventos sociais, ou falta de disposição para o estudo e aprimoramento profissional após a jornada de trabalho, restando somente o descanso ou o sono como uma necessidade de recuperação, preparação e prontidão para o próximo período de trabalho. A restrição das oportunidades de convívio social repercute diretamente na redução da rede de suporte social $^{2}$ do trabalhador, uma vez que, segundo HOUSE (1983), a condição mínima para experienciar suporte social é estabelecer relacionamentos estáveis com outras pessoas, imbuídos de sentimentos de afeto, afirmação e cuidado - considerando-se tanto a quantidade como a estrutura das relações sociais estabelecidas. $O$ suporte social oferecido pela família, pelos colegas de trabalho, vizinhos, parentes, amigos e conhecidos representam fortes aliados

\footnotetext{
${ }^{2}$ Suporte social é a rede de relações interpessoais, constituída pelo sujeito, que envolve proteção e apoio ligado a questões e necessidades emocionais, a cuidados instrumentais, ao fornecimento de informaçres e à auto-avaliação das condições do sujeito e sua vida. O suporte social pode modificar o estresse e, indiretamente, promover a saúde por meio de diversos mecanismos que reduzem a experiência do estresse $\mathbf{e}$ melhoram a saúde, especialmente no que diz respeito à redução do impacto e à atenuação dos efeitos deletérios do estresse sobre a saúde (HOUSE, 1983).
} 
na proteção à saúde mental e psíquica do trabalhador(HOUSE, 1983; VASQUES-MENEZES, CODO e MEDEIROS, 2000 e VASQUES-MENEZES e SORATTO, 2000).

Cabe, ainda, lembrar que as boas relações sociais no trabalho também contribuem para a satisfação com a função desempenhada bem como para a lida com conflitos e situações estressantes, aumento do círculo de amizades, melhoria das condições pessoais, físicas, psíquicas e da qualidade no trabalho, com impacto positivo na subjetividade do trabalhador. Enfim, conforme HELMAN (1994) e SORATTO e RAMOS (2000), os valores culturais, o amparo e o apoio social e o senso de coesão de grupo são fatores de proteção contra o estresse em todas as fases da vida, ajudando o trabalhador a melhor enfrentar as agruras do trabalho e os problemas cotidianos.

Assim sendo, em conformidade com HECKERT et al. (2001), pensar as questões de saúde do trabalhador requer acenar para a possibilidade de problematizar a vida cotidiana e criar possibilidades de expansão do viver e das formas de vida e trabalho; fazendo da saúde um assunto e compromisso de cada sujeito, de cada grupo social e de todos os que vivem a experiência humana de prazer e sofrimento contidas nas conquistas diárias e no combate às adversidades cotidianas, afirmando, a cada momento, a vida em suas diferentes dimensões.

Outro aspecto que, mais recentemente, passa a ser considerado nos estudos sobre as condições e a organização do trabalho docente é a preocupação com a dimensão de gênero e, nesse sentido, NEVES e SILVA (2001) denunciam a não- visualização e o não-entendimento do sujeito-mulher nos mundos do trabalho. Mesmo ocorrendo um aumento gradual e significativo da participação de homens no magistério (Educação Infantil, Ensino Fundamental e Ensino Médio), a prevalência ainda é de mulheres e isso requer a compreensão das especificidades de gênero na atividade docente (SEIFERT, 1999). 


\section{2) A MULHER PROFESSORA - QUESTÕES DE GÊNERO, SUBJETIVIDADE E VIDA PRIVADA}

LOURO (1997) assinala que não é possível compreender a história das mulheres na sala de aula e na docência, nem mesmo as posições de sujeito que ocupam ou a constituição de suas subjetividades, sem considerar que tal história se dá num terreno de relações de gênero, em que vogam as representações sobre o masculino e o feminino, os lugares sociais a eles previstos e as práticas sociais que assumem, rejeitam ou transformam as representações de gênero propostas pela sociedade.

A atividade docente, no Brasil, iniciou-se por homens - religiosos, especialmente os jesuítas - no período entre 1549 e 1759 e, posteriormente, foram eles que se ocuparam do magistério. Em 1827, proclamada a primeira lei de instrução pública ficou estabelecido que "escolas de primeiras letras" haveriam de ser estabelecidas em todas as cidades, vilas e lugarejos mais populosos do Império. A tal lei reclamava, inclusive, pela educação feminina que, mais tarde, nas últimas décadas do século XIX, seria justificada pela necessidade de modernização da sociedade, educação e construção da cidadania das crianças e jovens e higienização da família, tendo por finalidade a mulher educada e melhor preparada para o seu destino de mãe. Aos poucos, nas escolas foram criadas classes de meninos e de meninas, com conteúdos programáticos diferenciados e, para as meninas, tornou-se necessária a presença de professoras mulheres a fim de orientá-las. Com o aumento da demanda escolar, surgiram as primeiras escolas normais para formação de professores e professoras (LOURO, 1997).

Nas últimas décadas do século XIX e primeiras do século XX houve um aumento de ocupações mais rendosas na sociedade e os homens passaram a ocupar tais vagas; com a conseqüente diminuição da presença dos homens nos cursos e profissões ligadas ao magistério aumentou a procura das mulheres, ansiosas por ampliarem o seu universo, até então restrito ao lar e ̀̀ igreja.

$\mathrm{Na}$ sociedade, o imaginário do locus feminino define a mulher como pertencente a uma dinâmica "alheia", como ser "do lar", "da família", "do casamento", "da maternidade", ou seja, a ela são atribuídas funções de responsabilidade social oculta, que permanecem no nivel do privado e que exigem dedicação e doação (BRITO e D'ACRI, 1991). Nesse imaginário social, casamento e maternidade eram a "verdadeira" carreira feminina e, conforme LOURO 
(1997; p. 454), "a incompatibilidade do casamento e da matemidade com a vida profissional foi (e continua sendo) uma das construções sociais mais persistentes".

Além disso, no início do século $\mathrm{XX}$, a mulher bem como as crianças eram vistas como frágeis, desqualificadas e infantilizadas e, assim, precisavam ser protegidas, tuteladas e controladas. Então, qualquer atividade da mulher, fora do espaço doméstico representava um risco. O próprio trabalho era visto como uma fatalidade que afastava a mulher da vida familiar, dos deveres domésticos, da alegria da maternidade e da pureza do lar (ASSUNÇÃO, 1996 e LOURO, 1997). Havia "uma associação freqüente entre a mulher no trabalho e a questão da moralidade social, sendo que no discurso de diversos setores sociais destaca-se a ameaça à honra feminina representada pelo mundo do trabalho" (RAGO, 1997; p. 585). Fica evidente que essa visão está associada à vontade da sociedade de direcionar a mulher para a esfera do privado.

No contexto dessa sociedade machista, ao se feminizarem algumas ocupações - dentre as quais o magistério - identificaram-se algumas funções "possíveis" de serem exercidas por mulheres, e as quais configurassem representações da matemidade. Foi assim que o magistério, por possibilitar que a professora veja, em cada aluno/aluna um filho ou uma filha "espiritual" seu/sua, passou a configurar uma atividade aceita socialmente como um trabalho feminino e, uma vez que assim representado, não mais subverteria a função da mulher na sociedade mas, ao contrário, poderia ampliá-la ou sublimá-la (LOURO, 1997).

Desta maneira, numa sociedade predominantemente patriarcal, a escola seria uma extensão da família e do lar, onde a mulher, por vocação e amor às crianças, ocuparia lugar permanente em sua formação e assistência, numa maneira de superar a contradição entre o papel de mulher casada e o de profissional. Assim é que, até a década de 30 a única profissão plenamente aceita pela sociedade, para a mulher, era a docência.

Desenvolve-se, dessa forma, uma associação entre a mulher e o magistério, originária de uma representação criada a partir de um caráter de vocação mais do que de profissão - uma função que decorre da combinação de elementos do modelo religioso com o da maternidade, $\mathrm{e}$ que corresponde às expectativas do que seria o ideal de trabalho feminino, aquele que represente a continuidade dos afazeres no lar, circunscrito à esfera do privado ${ }^{3}$. Assim, a

\footnotetext{
${ }^{3}$ Privado esse que, segundo BRITO e D'ACRI (1991), é mais espaço de privação do que de privacidade e/ou intimidade; de privação da relação com os outros e da ação na construção das decisões concementes ao mundo da existência política.
} 
escola há de ser, para a professora, um novo lar: a escola adquire o caráter da casa idealizada, limpa, cuidada e protegida das ameaças do mundo externo e, para a professora sentir-se "em casa", ela assume, na escola, papel de "mãe" dos seus alunos. O trabalho docente, nessa perspectiva, implica dedicação-disponibilidade; humildade-submissão; abnegação-sacrificio; sacerdócio ou missão e exige amor, paciência, cuidado, afetividade, sensibilidade, abnegação, vigilância, dedicação e doação (NOVAES, 1995; ASSUNÇÃO, 1996; LOURO, 1997; NEVES e ATHAYDE, 1998 e 2001; NEVES e SILVA, 2001; ROCHA e GOMES, 2001).

Nas décadas de 30 e 40, as professoras ganham a nominação de educadoras, ampliando-se o caráter de sua atividade para fornecer apoio afetivo, emocional além de exercer função corretiva das crianças tidas como desviantes ou inadaptadas. Nas décadas de 60 e 70, o discurso de profissionalismo do ensino soma-se à repressão do regime militar, com um discurso didático-pedagógico que era traduzido numa regulação direta dos agentes educativos e do processo de ensino-aprendizagem; disciplinamento dos procedimentos de ensino e burocratização das atividades escolares, relegando o afeto e a informalidade a um plano secundário.

Nesse contexto, numa tendência de reafirmação da afetividade, muitas professoras passaram a utilizar a denominação de "tia" identificando-se mais como um parente da criança do que como sua mestra. Volta-se, assim, a revestir o espaço escolar de características doméstico-familiares, num processo que também contribuia para o anonimato da professora, chamada indiscriminadamente de "tia" ao invés de ser identificada pelo seu nome.

A supervalorização do caráter afetivo, o escamoteamento do conteúdo técnicoprofissional e a minimização e desqualificação da competência técnica vão, gradualmente, esvaziando o sentido de trabalho assalariado da docência (especialmente em se tratando do que hoje se considera a Educação Infantil e o Ensino Fundamental) o qual, por ser considerado "trabalho de mulher", é desvalorizado e visto apenas como "complementar à renda familiar".

A professora acaba construindo sua identidade pessoal e profissional em meio a paradoxos nas relações sociais nas quais ela tem que ser, ao mesmo tempo, dirigida e dirigente; profissional e mãe espiritual; disciplinada e disciplinadora; controlada e controladora. Isso gera os embates e as diferenças entre como o trabalho deve ser e a realidade de como ele se apresenta; entre como a professora deve ser e como ela se apresenta; entre a 
necessidade de trabalhar e o vínculo com as obrigações domésticas e a dedicação à própria família que gera a intensificação da carga de trabalho (escolar e doméstico/familiar). Instauram-se, aí, tensões subjetivas, conflitos, angústias, frustrações, sofrimentos e adoecimentos, em função da impossibilidade de conciliação dos dois tipos de atividade ou de dedicação integral a essas esferas sociais (HELMAN, 1994; ASSUNÇÃO, 1996; REINHOLD, 1996; BRITO, 1999; BATISTA e CODO, 2000; FONTANA, 2000; VASQUES-MENEZES, CODO e MEDEIROS, 2000; ROTEMBERG et al. 2001).

Muitas vezes, as dificuldades em conciliar os dois tipos de trabalho, profissional e doméstico/familiar, acabam repercutindo numa interrupção na atividade e na carreira profissional, ocasionando trajetórias profissionais descontínuas, com implicações também na qualidade de vida da pessoa. A própria descontinuidade tem repercussões diretas no quadro de saúde-doença, já que interrupções e retornos podem assumir uma representação de precariedade, instabilidade e insegurança (BRITO, 1999). No conjunto dessas intensas demandas sociais de envolvimentos e responsabilidades explícitas ou ocultas que geram sofrimentos, o fenômeno da despersonalização pode surgir como resposta ao sofrimento instalado, como um sentimento amargo de distanciamento emocional que nega a mediação afetiva inerente à ação docente e às relações familiares. - No que concerne à Fonoaudiologia, quando a mediação afetiva é negada, o que pode se esperar da qualidade da voz?

Assim, pensar a saúde da mulher trabalhadora pressupõe situar as mudanças nas relações de trabalho e também em todos os planos da vida. É preciso compreender o processo saúde-doença docente nas nuances e diversidades que compõem o mundo do trabalho e da experiência, na complexidade que envolve as histórias de vida, na importância do trabalho na construção da identidade e da subjetividade e, também, no não-reconhecimento e na invisibilidade social das características agressivas das condiçães e organização do trabalho, que expõem os sujeitos a diversas formas de adoecimento. Propõe-se um conceito ampliado de trabalho, que engloba também o trabalho doméstico e que interage com a reprodução social, com os modos de vida da sociedade e com as relações sociais, de classe e de sexo (BRITO e D'ACRI, 1991 e BRITO, 2000). 


\section{3) A RElaÇÃo professor-AlunOS: A AUTORIDAde e a QUESTÃo dA INDISCIPLINA}

Diversos estudos em saúde vocal do professor indicam a indisciplina e o barulho em sala de aula como problemas importantes. A maioria dos trabalhos menciona a indisciplina dos alunos na perspectiva do que ela representa acusticamente, ou seja, como ruídos de fundo ${ }^{4}$ no ambiente escolar, levando o professor a uma competição sonora ou a gritar em sala de aula - aspectos esses que, segundo SMTTH et al. (1997), somados ao uso prolongado da voz e à exposição a infecções de vias aéreas superiores, configuram altas demandas que afetam negativamente $o$ aparato vocal do professor. Poucas vezes, entretanto, observa-se a abordagem do problema da indisciplina num contexto mais abrangente, que envolva os processos da relação professor-alunos e os impactos sobre os sujeitos envolvidos.

Os processos vivenciados na relação professor-aluno têm um impacto importante na construção da sua subjetividade enquanto trabalhador, pois é principalmente no contexto dessas relações que seu papel social se concretiza e ganha significado e sentido, ou se esvai.

As relações intersubjetivas e a vinculação afetiva entre professor/alunos se dão no contexto da cultura e das condições e organização do trabalho docente, sofrendo a interferência dos embates, descompassos, distanciamentos e negociações entre trabalho prescrito e trabalho real, bem como das tensões e sentimentos de conflitos, angústias e sofrimentos que deles decorrem (FURLANI, 2000 e ROCHA e GLIMA, 2002). Tais relações incidem de diversas maneiras nas 24 horas do dia e na vida do professor (BETANCOURT e PALACIOS; 1999).

Entendo ser na diversidade e na dinâmica dessas relações e vinculações que a voz.do professor assume suas formas possíveis; daí a importância de se refletir sobre alguns processos subjacentes e determinantes dos posicionamentos por ele assumidos, principalmente tomando-se como referência a idéia de um professor que é levado a usar sua voz sob intensa demanda vocal (aqueles que falam demais, que falam o tempo todo, que falam alto ou até gritam). As contribuições dos diversos autores auxiliam a melhor compreender os processos

\footnotetext{
${ }^{4}$ BETANCOURT e PALACIOS (1999) consideram o ambiente escolar como altamente ruidoso, jả que as medições de ruído realizadas em salas de aulas e pátios das escolas apontaram para níveis entre 70 e 90 decibéis.
} 
subjacentes à relação professor-aluno. Dessa forma, espera-se ampliar o foco de interpretação das questões de uso da voz na docência para além da hipótese reducionista e simplista de que o professor usa a voz intensamente por que é "descuidado" ou "mal informado".

A seguir, apresento algumas considerações de diferentes autores de três campos do saber: Psicanálise, Lingüística e Educação; que representam contribuições complementares para a interpretação e reflexão sobre os processos envolvidos na relação pedagógica, mais precisamente no espaço da interação professor-aluno - lugar mediado pela linguagem/voz.

Autoras como KUPFER (1982) e MORGADO (1995), apoiadas em referencial psicanalítico, abordam a questão da autoridade e do poder como centrais na relação pedagógica, onde entra em jogo a dinâmica da transferência - o professor é objeto de uma transferência das idealizações e experiências vividas anteriormente pelos seus alunos.

O poder, para essas autoras, é o aspecto central organizador de toda e qualquer relação pedagógica: o poder de influência do professor sobre o aluno só se efetiva na medida em que ele é investido da herança da relação afetiva do aluno, primitivamente dirigida ao próprio pai, num jogo de identificações que envolvem idealizações e distanciamentos entre a imagem idealizada e a realizada. Os sentimentos de admiração e de ligação são transferidos do pai para o professor e o que está em jogo é algo vivido pelo aluno com seu pai, que será revivido com o professor.

Assim, a relação professor-aluno instaura-se numa reedição do protótipo da relação original de autoridade paterna, das figuras originais de autoridade na vida do aluno. Definindo previamente.quem irá se submeter e quem irá investir-se de autoridade, pela assimetria entre o genitor/professor - que sabe e que provê -, e a criança/aluno - que quer saber e ser provida -, a relação pedagógica reedita e reforça, pelos vínculos transferenciais na relação professor-aluno, a relação original de poder e de autoridade.

Ao vislumbrar no professor aquele que poderá provê-lo de conhecimento, o aluno elege-o como autoridade; ao ensinar, o professor exerce e legitima a autoridade que o aluno the atribui. A partir dos vínculos transferenciais, a intensidade e a natureza dos afetos primitivos, revividos nas relações atuais, favorecerá ou imprimirá obstáculos aos objetivos da nova relação. Assim, a transferência positiva de sentimentos ternos de afeição e respeito favorecerá a disposição do aluno em colaborar com o professor e a concretização dos objetivos educacionais; ao passo que a transferência negativa de intensos sentimentos cróticos ou hostis impedirá o aluno de reconhecer a autoridade do professor para ensinar e dificultará a cooperação com o professor e comprometerá os objetivos da 
relação pedagógica. O professor não é imune à transferência do aluno, à ternura, ao amor e ao ódio transferenciais; ele pode retribuir ou não esses afetos e tomar atitudes das mais às menos adequadas, mas terá sempre como ponto de partida os afetos transferenciais dos alunos.

Para que o conhecimento ocupe o centro da relação pedagógica é necessário que a intensa transferência afetiva de amor e/ou de ódio dê lugar aos sentimentos ternos e à curiosidade necessários à emancipação intelectual do aluno. Para que a relação pedagógica se desenvolva, é necessário que esse primeiro momento seja superado: o aluno deverá caminhar das paixões pelo professor para a paixão pelo conhecimento. $O$ papel do professor é fundamental, pois, o modo como ele se coloca nesse lugar conferido pelo aluno resulta em diferentes tipos de relação no processo ensino/aprendizagem.

KUPFER (1982) e MORGADO (1995) advertem para os problemas decorrentes das maneiras como os professores respondem a essa transferência inaugural dos alunos, especialmente no sentido de evitarem abusar do privilegiado lugar de ideal/modelo, ou mesmo de buscarem, nesse lugar, a satisfação do próprio narcisismo e do próprio ideal, sob pena de se instaurar o autoritarismo na relação pedagógica (o que se manifestaria na sobreposição do desejo soberano do professor sobre o do aluno), num contexto em que é o olhar do professor que aprova ou condena; é a boca do professor que fala e, falando, cala o discurso do aluno.

A advertência de MORGADO (1995; p. 86) refere-se às oscilações entre o abuso da autoridade do professor, seja pela sedução da omissão (em que o professor se exime do seu lugar), seja pela sedução da presença patemalista-maternalista (em que o professor, por prover demais, sufoca a capacidade crítica dos alunos), levantando alguns pontos para reflexão:

"na relação pedagógica, o professor exerce sua autoridade quando ensina; mas como ensina? Estabelece a mediação entre o aluno e o conhecimento social ou trata o conhecimento como propriedade individual? Trabalha para que o aluno possa vir a se negar como aluno ou trabalha para que o aluno seja eternamente dependente do professor? Trabalha para romper a dominação da autoridade original ou, ao contrário, recorre inconscientemente a ela?"

As autoras dispõem sobre o que seria o esperado numa relação pedagógica bem sucedida. Trata-se do professor, no campo contra-transferencial, aceitar a transferência do aluno, aceitar a sua ternura respeitosa e afetuosa, não para reagir a ela, mas sim para ajudá-lo a trabalhar, e, no lugar da contratransferência à transferência negativa de amor e/ou ódios exacerbados, colocar o conhecimento, elemento que legitima a autoridade pedagógica do 
professor. O educador que permita emergir a palavra (existência, saber, discurso, desejo) do aluno, que não se renda ao narcisismo e se coloque diante da possibilidade de perder seu "domínio" e sua centralidade, permitindo a superação da dependência do aluno em relação à figura do professor, estaria ele contribuindo para uma educação bem sucedida no sentido de preparar pessoas para conviverem com a liberdade na luta por um mundo socialmente mais justo. As autoras reconhecem, no entretanto, que essa possibilidade se encontra ainda longe de sua concretização, uma vez que, historicamente, a Educação vem apresentando sistemas pedagógicos autoritários, subordinados a imagens de ideais estabelecidos e assentados sobre as bases do exercício do autoritarismo.

A referência dos trabalhos anteriormente discutidos permite apreender que os usos da voz na relação pedagógica encontram-se situados num contexto permeado pelo poder e pelo autoritarismo, através de jogos de sedução e de transferências, de idealizações e de satisfações narcisistas que podem responder, inclusive, às necessidades do próprio professor.

Sob uma outra perspectiva, a lingüístico-discursiva, ORLANDI (1996), considera que a instituição escolar, através das suas convenções e hierarquias, exerce uma reprodução dissimulada das hierarquias sociais e de perpetuação do poder, num processo em que pesa a autoridade do discurso pedagógico. Para essa autora, o discurso pedagógico aparece enquanto discurso do poder, discurso autoritário, que, falando numa voz segura e auto-suficiente, contém a polissemia e estanca a reversibilidade fixando posições: o discurso pedagógico mantém o aluno na posição de ouvinte e o professor na de locutor pois, nele, o professor é idealmente aquele que possui o saber e está na escola para ensinar, e o aluno é aquele que não sabe e está na escola para aprender. Assim, o professor é quem fala, é ele quem assume o espaço de demanda vocal em sala de aula, numa rigidez de posicionamentos em que não sobra espaço para o discurso do aluno.

O rompimento dessa circularidade seria possível através da interação mútua professoraluno, na instância da interlocução. Isso, do ponto de vista do professor, implicaria que ele se colocasse de forma polissêmica, expondo-se a efeitos de sentidos possíveis e deixando espaço para a existência do aluno como sujeito no discurso, assumindo e aceitando, também, o professor, a posição de ouvinte. $\mathrm{E}$, do ponto de vista do aluno, implicaria a sua capacidade de 
discordância e de crítica e da possibilidade de ele posicionar-se como autor na dinâmica da interlocução.

Em suma, a autora questiona as condições de produção dos discursos pedagógicos e as concepções de educação, o que permite apreender que os usos da voz na relação educativa são transpassados pela cultura de uma sociedade que tem na escola, e mais precisamente no discurso pedagógico, um lugar de exercício e reprodução social do poder e da autoridade.

Numa terceira perspectiva, autores da área de Educação (FREIRE e SCHOR, 1990; GUZZONI, 1995; GUAZZELLI, 1999 e FURLANI, 2000), abordam o conceito de autoridade e algumas concepções que envolvem ideários de disciplina e de vivências da relação professor-aluno, apresentando contribuições para o entendimento dos posicionamentos assumidos pelo docente na relação com os alunos e que auxiliam a compreensão de alguns determinantes culturais da demanda de uso da voz do professor.

A autoridade (e não o autoritarismo) é indispensável na relação pedagógica, refletindo a essência do papel do educador, qual seja: constituir-se como mediador entre o conhecimento elaborado e o que será construído pelo aluno; ser líder e parceiro do caminho do conhecer; saber transformar o sujeito aprendiz, antes dependente do professor, em alguém participativo e independente no pensar e no agir, num agente transformador da realidade. Nessa perspectiva, quando os alunos entendem que a autoridade do educador visa à sua autonomia e libertação e legitimam o poder do professor no reconhecimento do seu saber e da sua experiência, eles respondem ao mestre com confiança, aceitação e respeito.

É preciso, portanto, diferenciar autoridade e autoritarismo: considerando esse último o desrespeito do professor pelo aluno e a negação da autonomia do educando perante o conhecimento, num contexto em que predomina a coerção que gera agressividade e que intimida o aluno, mantendo-o numa relação de dependência frente ao professor (GUZZONI, 1995).

FURLANI (2000) considera três tipos básicos de vivências da relação professor-aluno e, dado a importância dessa classificação para o presente estudo, eles serão abordados detalhadamente a seguir, quais sejam: a) o professor como controlador/vivências autoritárias roteiro de aula tradicional; b) o professor como facilitador/vivências democráticas e c) a ausência de disciplinamento/vivências permissivas. 
a) o professor como controlador/vivências autoritárias - roteiro de aula tradicional

Nessa modalidade relacional, o professor controlador centraliza o poder, sendo que a autoridade é exercida através da ocultação do poder ou sua transferência para a instituição/sistema educacional. Enquanto valores de disciplinamento, a expectativa é a de um aluno submisso, obediente, respeitoso e dependente em relação ao professor. Não há confiança no aluno, que é visto como imaturo, incapaz ou enganador. As estratégias que o professor controlador emprega para disciplinamento são as ameaças, tais como o manejo da nota e da frequêencia do aluno, utilizados como punição. A vivência característica é a de autoritarismo, com ausência de diálogo. O professor é o detentor e agente exclusivo da transmissão do conhecimento, da avaliação da situação pedagógica e do disciplinamento - que, por serem sempre realizados via controle, costumam despertar a insatisfação do professor e dos alunos.

No modelo de ensino tradicional, as formas autoritárias e a idéia de ter controle em sala de aula estão relacionadas com o estereótipo do bom professor, aquele que fala para alunos que escutam, aquele que se vale do disciplinamento para controle e sancionamento dos alunos, numa relação educativa, muitas vezes carente de sentidos e de significados para 0 aluno, cuja subjetividade é abafada, onde ele não tem lugar, não tem vez, não tem voz (CRAGNO, 1992 e GUAZZELLI, 1999).

Nesse modelo de aula tradicional, o professor controlador tem um roteiro dramático, investido pelas relações e pelo discurso autoritário que exigem dele que fale alto, destacando as palavras, em voz forte, e fale muito sobre assuntos que interessam marginalmente aos alunos, na tentativa de obter atenção face à resistência, numa dominação verbal do professor que cria o silêncio do aluno (FREIRE e SCHOR, 1990).

\section{b) o professor como facilitador/vivências democráticas}

O professor facilitador é o segundo tipo apontado e, nesse caso, a questão da disciplina não diz respeito somente ao aluno, mas relaciona-se à organização da aula e ao auto-domínio de professor e alunos em sala de aula, baseado na co-responsabilidade e no compromisso 
mútuo. Essa visão não subestima a autoridade na relação professor-aluno, mas possibilita o exercício conjunto de poder, evitando ameaças ou punição, ao mesmo tempo em que privilegia como valores a confiança, o crédito, a cooperação, a participação, o respeito e a autonomia do aluno. Tal relação caracteriza-se por vivências democráticas, pelo diálogo e elaboração, desenvolvimento e reelaboração conjunta do conhecimento na interação professor-aluno. A colocação de limites e sentimentos do professor, de forma a proteger suas necessidades e seu desempenho é presente; entretanto, o relacionamento com os alunos é perpassado pelo acolhimento caloroso e pela confiança. Ao professor, cabe conhecer o aluno, ouvi-lo, entendê-lo e colocá-lo em seu lugar, sem esquecer seu próprio lugar de docente .

Esse profissional é chamado por FREIRE e SCHOR (1990) como professor libertador, que se caracteriza por uma reinvenção verbal no ensino, como uma das formas de se opor às características destrutivas da educação passiva, daquela que silencia os alunos, levando-os a resistirem ao diálogo. Os autores reconhecem que os alunos não são silenciosos por natureza, mas que isso é criado pelas artes da dominação. Nessa proposta de reinvenção verbal do professor libertador, nessa recriação vocal através do diálogo, está implícita a idéia de que os alunos têm muito a dizer. $O$ professor libertador começa sua invenção criativa no momento de falar: modula a voz em ritmo de conversa, ouve atentamente cada pronunciamento dos alunos e pede aos demais que também ouçam quando um de seus colegas fala e que falem a respeito do comentário que o colega realizou. Há um professor que fala e escuta, e recria-se o aluno como alguém que escuta e fala.

Para FREIRE e SCHOR (1990; p.123), “o diálogo libertador é uma comunicação democrática, que invalida a dominação e reduz a obscuridade, ao afirmar a liberdade dos participantes de refazer sua cultura". Para os propósitos desta pesquisa, entendo que o conhecimento não é de posse exclusiva do professor; o objeto a ser conhecido é colocado entre os sujeitos cognitivos para sobre ele fazerem uma investigação conjunta, por meio do diálogo, como assinala FREIRE (1982), a educação é comunicação, é diálogo, na medida em que não é transferência de saber ou transmissão de conhecimento de um sujeito a outro, mas sim um encontro de sujeitos interlocutores em co-participação, no ato de compreender e construir significações. 


\section{c) a ausência de disciplinamento/vivências permissivas}

No terceiro tipo, em que há ausência de disciplinamento, o professor opta pelo repasse da responsabilidade e da tomada de decisões para o grupo de alunos. A vivência permissiva caracteriza-se pela total liberdade, em que tudo é deixado acontecer em sua forma espontânea, sem limites. O professor não assume os papéis e atitudes deles decorrentes, ocasionando ausência de orientação e de direção no processo ensino-aprendizagem do aluno. Sem assumir seu papel, ele destitui-se do significado social da sua prática.

Os ideários de ensino e de relação professor-aluno repercutem, assim, nos posicionamentos assumidos pelo professor em sala de aula, bem como sobre os usos e funções da voz docente. Ao que tudo indica, os modelos de ensino tradicionais, autoritários, centralizadores ou controladores são os que mais exigem do docente, os que implicam maior exposição do professor, os que mais predispõem aos conflitos na relação professor-alunos, os que mais se relacionam a sofrimentos do trabalhador e os que mais requerem o uso da voz do docente. Nesses modelos, observa-se um "verbalismo" exacerbado do mesmo, num intenso emprego da voz como um dos esforços - talvez o principal - para demonstrar firmeza, autoritarismo, obter a atenção e manter a ordem e a disciplina dos alunos na escola (CRAGNO, 1992; FERNANDES, 1998; SERVILHA et al., 2001; CARNEIRO, 2001 e GRILLO, 2002).

A partir das referências de KUPFER (1982), ORLANDI (1996), GUAZZELLI (1999), FREIRE e SCHOR (1990) e FURLANI (2000) é possível apreender que a figura do professor democrático, facilitador ou libertador seria a que representaria o posicionamento mais salutar em relação ao uso da voz na docência, não somente em relação à redução da demanda de tempo de uso da voz em que isso implica, mas também em relação à possibilidade de um relacionamento professor-alunos menos tenso e conflitante, o que já resulta num uso de voz mais natural e com menor esforço. 
Há que se considerar, ainda, que a indisciplina continua incomodando o professor, e continua, também, evidenciando dificuldades em olhar e compreender os alunos, em lidar e com eles se comunicar. Para GUAZZELLI (1999), a indisciplina e o barulho são sinalizadores de negação e de rejeição por parte dos alunos, tentativas de inviabilizar aquilo que o professor programou. Dessa maneira, o barulho e a indisciplina dizem respeito à subjetividade dos alunos, do lugar que eles querem ocupar na relação pedagógica e aponta para uma possibilidade de leitura das suas necessidades.

Diante do barulho e da indisciplina, o professor enfrenta um processo de afastamento, isolamento e distanciamento dos seus alunos, que o mobiliza a tomar atitudes como chamar a atenção, repreender, gritar, "dar sermão", a fim obter um momento de sua atenção e concentração. Estudos na área de educação demonstram que os esforços para manter a disciplina levam o professor a desempenhar papéis que ele não lhe dão prazer, ao mesmo tempo em que desperdiçam tempo útil e o sentido de aproveitamento da aula, gerando ansiedades, tensão e desgaste. Ao final, terminam por diminuir a auto-estima e despertar sentimentos de impotência, frustração, desânimo, angústia, ansiedade, irritação, estresse e desejo de fuga ou abandono da profissão (ESTRELA, 1994; REINHOLD, 1996; FONTANA, 2000 e FURLANI, 2000).

No que diz respeito à dinâmica vocal em sala de aula, DRAGONE (2000) lembra que ao elevar a intensidade se sua voz, para obter a atenção sobre si, causa um impacto negativo sobre os ouvintes, gerando ansiedades e imagens autoritárias e, freqüentemente, provoca reações de resistência, dos mais diversos tipos, que acabam por distanciar seus ouvintes. Desta maneira, quando se considera o processo saúde-doença vocal do professor, há que se levar em conta os processos implicados na questão da indisciplina e do barulho em sala de aula, uma vez que as sensações envolvidas abrangem e atingem diretamente a subjetividade do professor e a intersubjetividade da relação professor-aluno, incidindo sobre a comunicação em sala de aula - lugar de uso da voz!

A questão da autoridade e da indisciplina de maneira abrangente está relacionada à interferência dos aspectos subjetivos do professor e intersubjetivos da relação professoralunos, bem como às concepções de ensino imbuídas no trabalho docente, das condições de organização do trabalho docente e das questões sociais, históricas e culturais implicadas com a vida cotidiana em que o trabalho se desenvolve, e assim deve ser compreendida. 


\section{4 - PROCESSO SAÚDE-DOENÇA DE 'TRABALHADORES PROFESSORES}

O processo saúde-doença recebe, em cada segmento específico da sociedade, uma (re)interpretação, um significado e um comportamento, relacionados a uma combinação e relativização de saberes em que regem componentes culturais, sociais, étnicos, etários, econômicos e produtivos da sociedade (MINAYO, 1997-c e CAMPOS, 1997).

Para autoras como LAURELL (1982) e MINAYO (1997-c; p.32), a doença, “além de ser um fato biológico, é uma realidade construída, tanto historicamente, como dentro da expressão simbólica coletiva e individual do sujeito", pois se institui um discurso socialhistórico-cultural sobre o corpo, sobre saúde e doença; sobre o trabalho, a vida e a morte. A concepção de saúde e de doença é reveladora do grupo social, pois são acontecimentos culturais historicamente construídos de diferentes formas, em diferentes sociedades, sob diferentes condições estruturais, em diferentes relações e processos de trabalho e em diferentes grupos sociais. Assim, há sempre uma ligação entre sujeito e sociedade, entre sujeito e qualidade de vida.

A possibilidade de buscar relações entre trabalho docente, processo saúde-doença e qualidade de vida sinaliza um avanço necessário nas maneiras de olhar e compreender essas questões da vida dos professores de maneira integrada, superando as dicotomias e fragmentações, tais como aquelas observadas por GONÇALVES (1996), BETANCOURT e PALACIOS (1999) e por CARNEIRO (2001. Eles colocam que os professores dificilmente se assumem como trabalhadores e que têm um conhecimento fragmentado de seu corpo, não dando importância aos avisos biológicos por ele emitidos e, geralmente, interpretam o conceito de saúde de modo dicotômico, separando aspectos físicos e mentais, sem levarem em conta a qualidade de vida. É preciso, portanto, redimensionar o olhar sobre o professor como trabalhador, para melhor compreender o seu processo saúde-doença e os aspectos que o determinam.

A importância dessas relações, para a Fonoaudiologia, está em favorecer a visão das questões de saúde vocal do professor, numa perspectiva que supere aquela orgânico-funcional e normatizadora, para indicar caminhos no sentido de trazer as discussões, realizadas no âmbito das temáticas de saúde do trabalhador, para compor e orientar as reflexões sobre saúde vocal e 
voz profissional - especialmente com foco no espaço das relações de um trabalho que se dá na escola.

As questões estruturais da sociedade, a organização e as relações de trabalho desempenham um papel importante nas maneiras pelas quais o processo saúde-doença docente é percebido, sentido, interpretado, representado e enfrentado pelos professores. Para NAKAMURA (1997; p.75), a sociedade atual, pela administração do tempo de trabalho e de lazer, contribui para uma des-sensibilização humana, para a redução, distorção e deformação nas maneiras de perceber, de sentir, de interpretar, de significar e de enfrentar as experiências cotidianas - em especial as experiências de sofrimento - o que resulta numa aparente "acomodação" ou "anestesiamento" dos sujeitos perante o próprio sofrimento e o alheio.

$\mathrm{Na}$ literatura, diversos autores reconhecem e referem alguns problemas de saúde comuns do professor, relacionados às suas condições de trabalho, dentre os quais destacam-se:

a) Problemas emocionais, de esgotamento mental e estresse profissional - incluindo, aqui, a Síndrome de Burnout ${ }^{\prime}$ - (O.I.T., 1981; CRAGNO, 1992; BARDOU DE CARVALHO, 1995; REINHOLD, 1996; SILVANY NETO et al., 1998; ABEL e SEWELL, 1999; BRITO et al,, 1999; KOHEN, 1999; SLEEGERS, 1999; CALVETE e VILLA, 2000; CARNEIRO, 2000; CODO, 2000; DANIEL E SCHULLER, 2000);

b) Doenças do aparelho respiratório e vias aéreas superiores, dor de garganta, faringites, laringites, rouquidão e disfonias causadas pelo abuso ${ }^{2}$ e mau uso da voz ${ }^{3}$ (O.I.T., 1981;

\footnotetext{
${ }^{1}$ Bumout é o sofrimento psíquico do professor que perde o sentido da sua relação com o trabalho e que culmina em exaustão emocional, despersonalização, falta de envolvimento pessoal no trabalho e em deixar de lado até mesmo as próprias necessidades (CODO e VASQUESMENEZES, 2000-b). Segundo FRANÇA e RODRIGUES (1999) o indivíduo com bumout sente-se esgotado, com pouca energia para o trabalho, é intolerante, rígido, inflexivel, pouco generoso, facilmente irritável, insensível e amargo com as pessoas no trabalho e até mesmo com os familiares e amigos, o que faz com que suas relações como ser humano sejam vividas como insatisfatórias, problemáticas e pessimistas.

${ }^{2}$ Abuso vocal relaciona-se mais a uma pobre "higiene vocal", bem como a comportamentos e alguns hábitos vocais: envolve uma produção da voz feita com muito esforço, com intensidade e/ou freqüência elevada e longa duração do tempo de fonação; envolve também a presença constante da tosse, do pigarro, do grito, da imitação de vozes ou o canto sem preparo (BOONE e MCFARLANE, 1994; PINHO, 1997; OLIVEIRA, 1998 e STONE JR, 1998). A qualidade vocal pode apresentar características de soprosidade e aspereza, sonoridade pobre, "quebras" na voz, pitch da voz agravado e ataque vocal brusco (NAVAS e DIAS, 1998). Abuso e mau uso prolongado da voz podem ser compreendidos como um maltrato às pregas vocais e à musculatura da laringe e da faringe que pode causar disfonais e alterações orgânicas laríngeas secundárias (NAVAS e DIAS, 1998 e OLIVEIRA, 1998).
} 
CRAGNO, 1992; BARDOU DE CARVALHO, 1995; SMITH et al., 1997; CARNEIRO, 1997; SILVANY NETO et al., 1998; KOHEN, 1999; BRITO et al., 1999; FERREIRA et al., 2002);

c) problemas cardiológicos, circulatórios e ortopédicos (O.IT., 1981 e BRITO et al., 1999).

KOHEN (1999) estabelece relações entre as condições de risco das escolas, as cargas laborais e os problemas de saúde individuais e coletivos dos professores nas escolas da Argentina e Equador e demonstra o aumento do desgaste do professor, centrado principalmente na sua corporeidade. $\mathrm{O}$ autor evidenciou o aumento de problemas como hipertensão arterial e enfermidades coronarianas nas escolas com melhores condições, observando que as patologias com maior prevalência entre os docentes foram resfriados, varizes, gastrite e estresse. Exceto as varizes e enfermidades coronarianas, as demais podem representar fatores predisponentes, determinantes e/ou agravantes de alterações na qualidade vocal, portanto passíveis de relações com problemas de saúde vocal do professor. $\mathrm{O}$ autor acrescenta, ainda, que uma disfonia pode alertar para cuidados mais abrangentes do que a Otorrinolaringologia e a Fonoaudiologia, no sentido de cuidados direcionados às condições de trabalho do professor.

A fadiga mental é citada por SOARES JÚNIOR et al. (1994) como a manifestação clínica mais freqüente e o processo de adoecimento mais evidente do profissional de ensino, envolvendo sintomas como: cefaléia, colite, hipertensão, alterações do sono, ansiedade, depressão e aumento da incidência de doenças como gripes, resfriados e infecções das vias aéreas superiores (COUTO e Cols., 1981). SORATTO e PINTO (2000) reconhecem o cansaço fisico e mental como parte integrante do trabalho docente, considerando, porém, que ele não pode ocorrer de forma crônica ou comprometedora da saúde do trabalhador. Para esses autores, o cansaço seria aceitável, conquanto possa ser resolvido com uma boa noite de sono, por um pouco de diversão, por um carinho do(a) companheiro(a) ou pela companhia dos filhos.

No caso do professor, a carga mental do seu trabalho relaciona-se a diversos fatores que repercutem no estresse docente, como conseqüência de relações complexas entre condições de

\footnotetext{
${ }^{3}$ Mau uso caracteriza-se pela emissão vocal excessiva, utilização de técnica vocal inadequada, presença de esforço e tensão ao falar, início da fonação abrupto ou com ataque vocal brusco e uso de pregas vestibulares na produção vocal (BOONE e MCFARLANE, 1994; COLTON e CASPER, 1996 e OLNEIRA, 1998). Abuso e mau uso prolongado da voz podem ser compreendidos como um maltrato às pregas vocais e à musculatura da laringe e da faringe que pode causar disfonais $e$ alterações orgânicas laríngeas secundárias (OLIVEIRA, 1998 e NAVAS e DIAS, 1998).
} 
trabalho, condições externas ao trabalho e características do trabalhador (ROCHA e GLIMA, 2002; ROCHA e JÚNIOR , 2002).

A Organização Internacional do Trabalho (O.I.T., 1981) indica ser o estresse profissional um dos problemas que afetam cada vez mais os educadores em seu ambiente profissional, pois prejudica a saúde dos professores, deixando-os susceptíveis a esgotamento mental e físico e, também, constituindo um motivo importante de absenteísmo, decepção e abandono da profissão. $O$ estresse docente tem sido definido como um conjunto de respostas de efeitos negativos, acompanhadas de transtornos fisiológicos em conseqüência das atividades do ensino e tem se convertido em um risco ocupacional significativo nessa profissão.

Segundo STACCIARINI e TRÓCCOLI (2002), os estressores, no ambiente de trabalho, podem ser fatores intrínsecos como:

- condições inadequadas: turno, carga horária, novas tecnologias, quantidade de trabalho, riscos;

- papéis: ambíguos, conflituosos, responsabilidade com pessoas e coisas;

- relações de trabalho: situações de interação social negativa e relações com clientes/alunos descontentes, dificuldades com superiores, chefias, direção, coordenação, colegas, subordinados e clientela;

- desempenho na carreira: insegurança quanto à manutenção do trabalho, falta de desenvolvimento na carreira;

- estrutura e cultura organizacional: comunicação pobre ou truncada, falta de participação, autoritarismos e vigilância constante do desempenho, pressões agressivas no sentido de aumento da produtividade no trabalho;

- interface trabalho-casa: falta de suporte social e dificuldade de administrar os

- limites entre trabalho e vida doméstica.

O processo de estresse envolve uma reação de alarme em que podem aparecer sintomas de natureza fisica como taquicardia, sudorese, dor de cabeça, palidez, pressão alta, fadiga, zumbido no ouvido, por exemplo. Segue-se, então, a fase de resistência em que ocorre a centralização da reação interna de estresse em um órgão mais vulnerável do corpo humano, desaparecendo os sintomas físicos da fase anterior e iniciando os sintomas psicossociais como irritabilidade, isolamento social, incapacidade de desligar-se, sensações de medo, dentre outros. 
O órgão vulnerável então entra em colapso e surgem sintomas específicos de patologias vinculadas a esse órgão. Ë a fase de exaustão (COELHO e VASCONCELOS, 2003).

O estresse relaciona-se aos distúrbios da voz, uma vez que grande parte das alterações vocais são devidos a dificuldades dos indivíduos em lidarem com as situações de estresse. Para COELHO, BEHLAU e VASCONCELOS (1996), a exposição contínua dos sujeitos a eventos estressantes negativos faz com que, na tentativa de adaptar-se, o organismo termine por concentrar sua reação de estresse num só órgão vulnerável - no caso dos disfônicos, a laringe. Autores como GIÃO et al. (1999), avaliando a voz e as condições de estresse ocupacional em professores universitários, indicam que os professores disfônicos estressados se encontravam na fase de resistência, com sintomas físicos bastante freqüentes, inclusive sintomas predisponentes das disfonias.

A relação afetiva professor-aluno também pode inaugurar conflitos e tensões decorrentes dos descompassos entre a necessidade de estabelecimento de um vínculo afetivo e a impossibilidade de concretizá-lo; entre a vinculação idealizada no trabalho prescrito e o tipo de vinculação possível de ser estabelecida no trabalho real. $\mathrm{Na}$ ausência de outros modos saudáveis de o professor dar vazão a essa sua energia afetiva, instaura-se um quadro de sofrimento do trabalhador, que repercute negativamente na relação com o trabalho e na sua vida pessoal do professor (CODO e GAZZOTTI, 2000; CODO e VASQUES-MENEZES, 2000-b; VASQUES-MENEZES e GAZZOTTI, 2000).

- Algumas vezes, ocorre de o professor sentir-se cansado de empregar sua energia afetiva e doar-se, sem obter retomo do afeto empregado, o que o leva a deixar de investir no seu trabalho e a se acomodar numa posição depressiva, sendo comuns as queixas de falta de energia, esgotamento e exaustão. É quando o professor pode fechar-se em si mesmo e perder o interesse pelo mundo externo e pelas relações afetivas e sociais, num processo de sofrimento silente. Nesse processo, a energia afetiva, que antes seria direcionada ao aluno, agora é deslocada para o próprio corpo do trabalhador, como energia negativa que conduz à formação de sintomas fisicos, principalmente na forma de dor. $O$ resultado é o sujeito agredindo a si mesmo, com sintomas de um sofrimento que podem envolver dores no corpo, dores de cabeça, dores nas costas, perda de voz, cansaço, irritabilidade, dificuldades em estabelecer relações afetivas mais profundas, chegando até à despersonalização. 
A despersonalização manifesta-se quando a energia afetiva do professor está bloqueada, sem redirecionamentos. $O$ professor acaba distanciando-se do objeto que demanda seu afeto, de maneira a minimizá-lo , evitando deixá-lo ser tão expressivo a ponto de se lhe configurar como uma ameaça. Trata-se de um processo de "coisificação" das relações, de torná-las impessoais e sem afeto, de afastamento do objeto que causa a dor. A despersonalização exprime-se, assim, como distanciamento emocional, frieza, insensibilidade, indiferença e postura desumanizada diante das pessoas e das necessidades dos outros. Há o desenvolvimento de intensos sentimentos de decepção, frustração, infelicidade e senso de inadequação, ao lado de sintomas como mal-estar, fadiga, esgotamento, perda de energia e de entusiasmo, desamparo e diminuição da auto-estima (FRANÇA e RODRIGUES, 1999).

Entretanto, estabelece-se uma nova tensão, pois a prática profissional continua cobrando $o$ afeto que lhe faz sofrer. A estratégia (inconsciente) pode ser, então, virar as costas fingindo que os conflitos não existem, fazer-se insensivel num mecanismo de endurecimento emocional que tende a desenvolver atitudes cada vez mais duras, rígidas, autoritárias, intolerantes, cínicas, sarcásticas e críticas em relação aos alunos, seus familiares e à própria sociedade - vistos como ameaçadores. Sob essa perspectiva, o mau humor e as discussões passam a fazer parte do seu dia-a-dia e cada aula é uma verdadeira batalha interna que o professor trava consigo mesmo - e da qual sai exausto.

Toda a psicodinâmica desse campo tensional entre prazer e sofrimento, afeto e razão, controle do meio e a imposição desse controle, tem sua origem nas relações sociais de trabalho e nas condições subjetivas e objetivas do trabalho docente e configuram os eixos bipolares que fazem a diferença entre o prazer e o sofrimento no trabalho e que produzem o burnout no trabalho docente, corroendo a relação do sujeito professor com sua profissão (FRANÇA $\mathrm{e}$ RODRIGUES, 1999; CODO e BATISTA, 2000 e VASQUES-MENEZES e GAZZOTTI, 2000). 


\section{5- LICENÇAS DE SAŨdE, ADESÃO E RESISTÊNCIA DO DOCENTE}

As formas de adesão e a resistência dos sujeitos, ao seu trabalho, são influenciadas pelo interesse das pessoas pelo próprio corpo e pela sua saúde, pelas representações sobre saúde e doença circulantes na sociedade e, ainda, pela representação que o trabalho assume para o trabalhador e para a sociedade em que vive.

Autores como LOYOLA (1984) e MINAYO (1997-c) evidenciam, na sociedade (especialmente em se tratando de parcelas mais empobrecidas da população), a representação social de que o corpo é feito para trabalhar, para produzir e, em decorrência disso, a representação de saúde e de doença está muito ligada à atividade física e à capacidade para o trabalho. Ou seja, a noção de força e utilização do corpo, nesse caso, é o princípio organizador das atitudes em relação ao corpo, à saúde e à doença, produzindo uma equivalência da saúde à produção e da doença ao não-trabalho ou à não-atividade. Tal representação que resulta no fato de o sujeito só se perceber e sentir-se doente quando sua capacidade produtiva chega a ser ameaçada.

A representação de saúde e de doença está ligada à capacidade para o trabalho e às condições laborais e societárias em que se desenrola o cotidiano da vida do professor, a ponto de que ele pode ser levado a deparar-se com a questão da des-sensibilização ao próprio sofrimento (NAKAMURA, 1997). Até mesmo a capacidade de auto-percepção do trabalhador, em relação ao funcionamento do próprio corpo ou aos seus sinais e sintomas, é mediada por esses valores de relação trabalho/saúde/doença (LOYOLA, 1984 e MINAYO, 1997-c).

Assim é que um professor com uma voz rouca, por exemplo, pode enfrentar dificuldades em sentir/perceber/identificar a sua problemática vocal.Pode não reconhecer de imediato o impacto dessa sobre si, sua saúde e sua vida, bem como em significar e representar tal problemática no contexto da sua vida e das relações sociais que estabelece no cotidiano. As representações sobre a concepção de processo saúde-doença são permeadas pelas questões do uso do corpo na produção; e uma representação de algo muito grave ou comprometedor da capacidade de trabalho conduz à predisposição para que o professor venha a subjugar ou 
mesmo negar o problema - o que implica, inclusive, deixar de procurar ajuda especializada e respostas apropriadas ao enfrentamento do problema vocal.

Na área fonoaudiológica, THOMÉ DE SOUZA (1998) e THOMÉ DE SOUZA e FERREIRA (2000-b), avaliando professores de escolas municipais de São Paulo, observaram que até $75 \%$ dos sujeitos apresentam, diariamente, queixas e sintomas de alterações vocais como rouquidão, cansaço ao falar, irritação na garganta e perda de voz associados ao uso demasiado da voz. Entretanto, somente 14\% procuraram atendimento especializado; e apenas $10 \%$ obtiveram licença médica devido a problemas vocais. Assim, as autoras observam que, mesmo com alterações de voz e sofrendo com os sintomas e queixas vocais diariamente, os professores resistem a buscar atendimento especializado em saúde vocal e continuam ministrando aulas e usando a voz de maneira inadequada, por longos períodos.

Esse professor pode seguir trabalhando e sofrendo, sem recorrer ao atendimento de saúde nem mesmo aos seus direitos previdenciários. Em geral, ele não falta ao trabalho, não busca tratamento e continua dando aulas, a despeito de sua voz rouca/alterada - por maior que seja o esforço ou sofrimento causado por sua disfonia ao falar, e por mais prejuízos que a alteração vocal traga para a relação professor-aluno e processo ensino-aprendizagem. Se a alteração vocal - apesar de comprometer a qualidade da função docente - ainda não chegou a se configurar como um impedimento à realização do seu trabalho, o professor continua falando e dando aulas (ainda que rouco ou com desconforto vocal) pois considera que não há comprometimento significativo da "produção" no âmbito do trabalho na escola.

Ao chegar a uma afonia, com perda total da voz, então sim, o professor percebe o comprometimento produtivo do seu trabalho. Sem poder contar com a sua voz, principal instrumento do trabalho docente, o professor não tem como dar aulas, não tem como trabalhar. Essa situação, via de regra, é que mobiliza o professor a buscar ajuda especializada; é nesse momento que esse trabalhador percebe a precariedade das suas condições de saúde vocal e geral; às vezes, quando um problema/patologia já se encontra instalado - um problema que, na maioria das vezes, poderia ter sido evitado, prevenido, contornado ou revertido se precocemente identificado e trabalhado.

HECKERT et al. (2001) identifica que as licenças de saúde são apontadas como elementos que alteram o funcionamento e a organização do cotidiano da escola, numa cultura de valorização e enaltecimento daqueles professores que, mesmo doentes, vêm trabalhar sem 
usufruírem do direito à licença. Essa cultura desdobra-se em sentimentos de culpa e desconfiança em relação àqueles professores que utilizam a licença médica - que passam a ser vistos como descompromissados com a escola, com os colegas e com os alunos. Nesse contexto, o trabalhador que se reconhece doente, sente-se culpado e pressionado, como se estivesse traindo a confiança da comunidade escolar. Por isso, os estudos demonstram que, ao sentirem-se doentes na escola, os professores buscam ajuda médica somente quando se encontram no limite de suas forças, quando as situações de mal-estar, geradas pelo processo de organização do trabalho, tornam-se insustentáveis, e/ou quando outros mecanismos de defesa não dão mais conta de agir (BRITO et al, 2001).

Assim, o que se observa é que a saúde não tem sido observada com a perspectiva de um bem a ser aplicado à vida cotidiana do sujeito - a não ser à parcela da vida do sujeito que diz respeito ao ser trabalhador ou na medida em que possibilite inseri-lo no sistema produtivo da sociedade. É possível que seja encontrada uma das respostas para o aparente desinteresse ou descuido de trabalhadores para com a sua saúde, sinalizando outras possibilidades de interpretação, para além da hipótese, tão difundida, de que os trabalhadores tardam a procurar ajuda especializada simplesmente por falta de informação ou de conhecimento. A voz nem sempre é contextualizada na realidade social e de trabalho, e são poucos os estudos e intervenções fonoaudiológicas que consideram as dimensões da voz do ponto de vista profissional, sendo um investimento necessário o de pesquisas que assumam a relação voztrabalho-relações pessoais.

FERREIRA (1999) observa que, na rede pública de ensino, são freqüentes as licenças, os afastamentos e as readaptações de professores, em decorrência de problemas vocais. Entretanto, cabe considerar que, muitas vezes, as queixas vocais levadas, pelos professores, aos profissionais da saúde acabam sendo subestimadas ou mesmo desconsideradas. Outras vezes, quando a atenção à saúde desse trabalhador ocorre, o atendimento se dá de maneira a negar e reduzir a complexidade que envolve os processos de adoecimento na escola, com condutas descoladas das questões gerais do processo e da organização do trabalho. A licença médica ou a readaptação não contribui para a superação do problema, a não ser para a individuação da doença e para a sua recidiva (BARDOU DE CARVALHO, 1995 e BRITO et al, 2001). 
Um estudo de BRITO et al. (2001), sobre incidência de casos de readaptação em trabalhadores da Rede Estadual de Ensino do Rio de Janeiro, acusa a ampliação das readaptações de professoras por problemas vocais e relaciona esse dado a fatores tais como: modificações nas condições e organização do trabalho docente que, ao aumentar as exigências sobre o professor, tornam o seu trabalho mais nocivo à sua saúde geral; a inadequação de materiais didático-pedagógicos e o aumento da indisciplina, com conseqüente aumento do ruído na escola, que conduziriam a um esforço vocal mais intenso. Segundo esses autores, a freqüência de pedidos de readaptação entre professores é bastante alta nas especialidades médicas de Psiquiatria e Otorrinolaringologia, intensificadas a partir de cinco anos de serviço. Há que se considerar a possibilidade de que muitos dos casos de readaptação dos sujeitos, por motivos otorrinolaringológicos e psiquiátricos, tenham relações com alterações vocais.

CARNEIRO (1997) realizou um estudo de 1182 Guias de Perícias Médicas (GPM) de um centro de saúde estadual e observou que $76 \%$ das pericias realizadas eram relativas à Secretaria de Estado da Educação; sendo 566 referentes a afastamentos de professores e, destas, $34 \%$ eram de professores de $1^{\text {a }}$ a $4^{\text {a }}$ séries, somente $4 \%$ eram de professores de $5^{\text {a a }} 8^{\text {a }}$ séries e a grande maioria, de $62 \%$, eram de professores de ensino médio. Investigou as causas de afastamento por licença médica e identificou as doenças do sistema respiratório (CID Grupo VIII) em primeiro lugar, seguidas pelas doenças do sistema osteomuscular e tecido conjuntivo (CID Grupo XIII) e as doenças relacionadas a transtornos mentais (CID-Grupo V). A autora observou um aumento crescente dos afastamentos nos meses de maio e junho, caindo em julho e voltando a aumentar em agosto. As doenças relatadas como do sistema respiratório incluíam nasofaringite aguda, laringite aguda, gripes, resfriados, sinusites, pneumonia, asma, bronquite, amigdalites, crises de afonia, distúrbios da fala, dentre outras. - Cabe, aqui, destacar que, em geral, todas estas patologias exercem influência negativa sobre a saúde vocal ou relacionam-se a alterações vocais.

Em um estudo mais aprofundado junto a professores de uma escola de Ensino Médio de Rio Claro, CARNEIRO (2001) observa que os professores se queixam, principalmente, de cansaço mental, esgotamento e rouquidão ao final do período, devido à dinâmica desgastante e exigente do trabalho realizado com adolescentes, num contexto que exige muito do professor de Ensino Médio: habilidade no tratamento com os alunos, colegas e superiores hierárquicos; capacidade de manter a disciplina e de controlar a classe, de superar conflitos e de expressar 
sensibilidade e afetividade; enfrentamento cotidiano, do ruído interno constante na sala de aula, da exposição constante à poeira e ao pó de giz, bem como da forte densidade emocional de um cotidiano de conflitos, excessos e abusos por parte dos alunos, expressos em atos de vandalismos, de atear fogo em alguns espaços da escola, de quebrar vidros e janelas, de fazer uso de drogas na escola, além de ocorrências policiais como crimes, roubos e danos, envolvendo a escola e veículos dos professores.

As maneiras pelas quais o trabalhador interpreta e significa o seu trabalho envolvem reações de adesão e/ou resistência individuais e coletivas que podem assumir formas variadas de expressão. Nesse sentido, CARNEIRO (2001) observou que são reincidentes os professores que tiram licenças de saúde e que estas são tidas como "rotineiras" e "necessárias" à sobrevivência/resistência desses professores frente às pressões escolares. Nessa mesma perspectiva, HECKERT et al (2001), estudando uma comunidade escolar em situação de uma organização de trabalho problemática, chegam a interpretar alguns pedidos de licença médica como formas de resistência dos trabalhadores aos processos adoecedores colocados em cena na escola. Os autores consideram que, no contexto daquela realidade específica, os pedidos de licença médica seriam, paradoxalmente, sinalizadores de saúde dos trabalhadores, na medida em que representam formas de subverter aquela organização de trabalho danosa. Nesse sentido, os pedidos de licença médica de alguns trabalhadores professores seriam importantes catalisadores coletivos em tempos de expropriação máxima do trabalhador; seriam maneiras de os professores darem visibilidade ao desconforto e à discordância em relação às formas de gestão implementadas no setor educacional. 


\section{6 - PERSPECTIVAS PARA A INVESTIGAÇÃO DA SAÚdE (VOCAL) DO TRABALHADOR PROFESSOR}

Saúde não é estado nem um bem que se consome, a ausência ou a soma de riscos ou de doenças. Saúde é um processo dinâmico que inscreve o corpo, a pessoa, os seus esforços, as suas perdas e vitórias, seus prazeres e sofrimentos. A saúde traz as marcas do trabalho da pessoa, da sua trajetória, das suas condições e estilos de vida, tudo isso num contexto que vai constituindo uma história individual do sujeito, na sua singularidade, mas também nos aspectos coletivos a que corresponde (CAMPOS, 1997; BRITO, 1999; FRANÇA e RODRIGUES, 1999).

Falar de saúde implica, portanto, falar da cultura de uma dada sociedade e dos grupos que a compõem; bem como um cotidiano que demanda mobilização do corpo e da alma, de um campo de negociações cotidianas e permanentes, por tornar a vida viável (ROCHA e GOMES, 2001).

A saúde não pode ser abordada somente do ponto de vista da sua conservação, mas requer acenar para a possibilidade de problematizar a vida cotidiana, criando novas questões, outras formas de estar no mundo, variando ass possibilidades de vida e trabalho e práticas que sinalizam processos de expansão do viver (HECKERT et al., 2001). Saúde é, assim, conquista diária, é combate contra as adversidades cotidianas, é compromisso de cada sujeito, de cada grupo de trabalhadores e da sociedade para com a realidade.

É sabido que nem todas as pessoas reagem da mesma maneira aos perigos de adoecimento, mas algumas situações afetam grupos inteiros e categorias de trabalhadores, $o$ que permite buscar conhecê-los e analisá-los a partir do seu caráter de homogeneidade (BRITO, 1999) relacionado às condições em que o trabalho se desenvolve.

A Fonoaudiologia, a Otorrinolaringologia e os serviços de Saúde do Trabalhador necessitarm avançar na consideração dos fatores determinantes dos problemas vocais em professores, no sentido de reconhecer que a alteração vocal nessa categoria profissional não é determinada simplesmente pelo uso prolongado ou excessivo da voz (ainda que na presença de ruído ambiental), mas que há outros fatores concorrendo para o seu desenvolvimento. 
Diversos autores consideram que os distúrbios vocais em professores são resultantes de um somatório de fatores que envolvem a falta de percepção da própria voz; o despreparo vocal e o desconhecimento das técnicas vocais; o uso abusivo e continuado da voz com esforço; o desconhecimento das normas de higiene vocal; a realização de uma pobre higiene vocal; as condições fisicas desfavoráveis do ambiente de trabalho; as classes numerosas; os baixos salários e a falta de reconhecimento social e profissional da categoria docente (NAGANO, 1994; DRAGONE, 1996 e 2000; RODRIGUES, AZEVEDO e BEHLAU, 1996; OLIVEIRA, 1998; THOMÉ DE SOUZA, 1998; BEHLAU, ANDRADE, MADAZIO e REHDER, 1999; THOMÉ DE SOUZA e FERREIRA, 2000-b; FERREIRA et al, 2003). Assim, evidencia-se, aqui, a indicação de fatores referentes à percepção e ao uso da voz, ao conhecimento/preparo em técnicas vocais, ao ambiente físico, ao número de alunos por sala e ao retorno social e financeiro ao trabalhador.

Apesar dos avanços que representam a atenção a esses aspectos na compreensão da saúde vocal e da realidade docente, gostaria de apontar alguns pontos para reflexão sobre tais considerações. Geralmente o foco recai sobre as questões de percepção e uso da voz, compreendidas como abuso/mau uso, desconhecimento de técnicas e hábitos vocais "higiênicos", realização de pobre "higiene vocal", e centra-se diretamente no indivíduo, de modo que responsabiliza e, às vezes, culpa o professor pelo seu processo saúde-doença vocal (afinal, ele é quem "não presta a devida atenção à própria voz"; é ele quem "maltrata" e "não cuida" da sua própria voz; quem "não sabe usar a voz direito"; é ele quem "não sabe colocar a voz com técnica"; e assim por diante).

Por outro lado, os estudos que enfatizam as condições salariais e do ambiente físico da escola não sugerem, a curto prazo, perspectivas transformadoras para a ação do sujeito professor em parceria com os profissionais da saúde, o que pode resultar numa postura queixosa, desanimada, fatalista e conformista que apresenta poucas possibilidades de mudança e transformação para o sujeito e para os profissionais da saúde envolvidos. Deste modo, que perspectivas sinalizariam possibilidades de intervenção fonoaudiológica mais integrais, amplas, abrangentes e efetivas junto à promoção da saúde vocal de professores?

O trabalho de VILKMAN (2000), que investiga as exigências de qualidade vocal e as demandas de uso da voz em diferentes profissões na Finlândia, traz uma contribuição importante nesse sentido; a começar, porque o autor leva em conta, no transtorno vocal 
ocupacional, não somente o parâmetro da voz "normal", mas também o quanto a voz preenche (ou não) os critérios exigidos por uma determinada profissão. Dá atenção às especificidades das necessidades vocais em cada tipo de trabalho que exige o uso profissional da voz de forma que, no caso do professor, $\mathrm{o}$ autor destaca a necessidade de resistência vocal.

Considera que os transtornos vocais ocupacionais configuram uma lesão por esforços repetitivos agravados por tensão e tratamento inadequado dos sintomas iniciais. Define ainda demanda vocal como uma combinação de tempo de uso da voz e fatores que afetam sua produção. $O$ autor esclarece que, na situação de ensino, o tempo de fonação tende a ocupar, em média, $30 \%$ do tempo; e as pregas vocais vibram de 15 a $40 \%$ do tempo, de maneira que um professor que dê 5 aulas de 45 minutos realiza cerca de um milhão de vibrações de pregas vocais diariamente durante o trabalho (sem contar o tempo de fala e uso da voz na vida social e privada).

Para esse autor, a habilidade de trabalhar enquanto ensina, poderia ser definida em termos de resistência vocal. Quanto aos fatores que afetam a produção da voz docente, indica os fatores individuais (hábitos e técnicas vocais pobres, hobbies com demanda vocal elevada, doenças respiratórias, hábitos e condições de vida desfavoráveis) e fatores relacionados ao trabalho (condições de acústica, tamanho da sala, equipamento e tratamento inadequado dos sinais sonoros, reverberação e ruído de fundo, qualidade do ar, poeira, distância entre os falantes e tamanho do grupo de pessoas para o qual se dirige a comunicação).

O autor critica a clínica na área de voz que enfatiza os aspectos psicológicos individuais de maneira a acusar o próprio sujeito como causador do seu problema de voz. Direciona o olhar clínico para as condições do ambiente de trabalho, aos hábitos vocais e às técnicas vocais utilizadas, à saúde e às condições gerais de vida. Ainda que esse texto não mencione o fator da qualidade das interações e relações interpessoais no trabalho, uma das grandes contribuições do autor para as pesquisas na área de voz profissional está em sugerir a consideração das necessidades vocais específicas em cada tipo de trabalho e da inclusão dos aspectos das condições gerais de vida e usos da voz no cotidiano (os hobbies), na busca de uma interação entre sujeito, usos da voz, necessidades e características do trabalho e condições gerais de vida, na compreensão do desenvolvimento, na avaliação e na intervenção das disfonias em docentes (indo além da questão do uso da voz em sala de aula). 
$\mathrm{Na}$ perspectiva da promoção da saúde vocal, concordo com SERVILHA (2000) e CHUN (2002), que é preciso reexaminar os determinantes de saúde vocal e identificar as direções necessárias no enfrentamento dos desafios olhando a voz sob outro prisma - o da dimensão social. Assim, considero fundamental, na compreensão ampla dos fatores intervenientes e determinantes das alterações de voz e questões de saúde vocal dos professores, a inclusão dos aspectos de subjetividade, das relações sociais no trabalho e fora dele, das condições e organização do trabalho e da vida cotidiana que configuram a qualidade de vida e os contextos nos quais a voz é produzida nas situações de interação e comunicação do sujeitotrabalhador-professor.

É reconhecida a existência de necessidades vocais específicas em cada profissão (VILKMAN, 2000 e BEHLAU, 2001-c); entretanto, o fato de reconhecer isso não significa uma rigidez ou um "engessamento" das características vocais, o que culminaria numa tentativa de padronização e de homogeneização vocal nas profissões. Assim, a voz dos professores não pode ser vista como um produto definido, homogeneizado ou acabado - isso negaria o impacto constitutivo dos contextos e das relações interpessoais sobre a voz e o próprio sujeito.

Entende-se que as opções de uso da voz (incluindo-se aquilo que é chamado de abuso ou mau uso), as técnicas ou recursos vocais empregados, bem como as variações que constituem a qualidade vocal do professor, não são aspectos estáticos, mas dinâmicos, na medida em que se constituem, se configuram e se transformam nas relações que o sujeito estabelece com a sua subjetividade e com seu meio social. Pois, como assinala CHUN (2002; p. 20), "a produção vocal de cada sujeito está estreitamente relacionada às condições, necessidades e exigências cotidianas e profissionais". Cabe, ainda, destacar, como FERREIRA (1999; p. 76), que “até mesmo a série para a qual o professor leciona pode determinar mudanças em seu comportamento vocal"... Dessa forma, entende-se que não há $a$ voz do professor, mas sim possibilidades de vozes e de usos vocais, assumidas pelo sujeito/professor a partir dos ajustes realizados em função da interferência dos aspectos relacionais, contextuais, culturais e históricos.

É preciso assumir que saúde e doença são mostras de expressão cultural; são formas significativas de se falar do contexto, da história, das experiências, das crenças e dos saberes tecidos pela sociedade de hoje e de ontem (CAMPOS, 1997). Assim, ao analisar a saúde vocal dos professores é preciso levar com conta que se está analisando a produção vocal em um corpo 
social que, conforme BARROS (2001), seja na sala de aula e/ou fora dela, se encontra submetido a uma determinada ordem, regulado, enquadrado, disciplinado, produtivo, no qual prevalecem certas relações de poder-saber que produzem objetos, subjetividades, necessidades, desejos, representações, em um continuum que representa a história e a vida do professor. Isso demanda que a ação em promoção da saúde vocal docente seja orientada no sentido de buscar abranger o conhecimento dos fatores contextuais, culturais, subjetivos e da realidade e qualidade de vida dos sujeitos professores. Implica, por outro lado, a consciência de que tais fatores interagem na construção da representação que o processo saúde-doença vocal assumepara cada sujeito, categoria de trabalhadores e comunidade (e, aqui, é muito provável que a representação dos professores acerca do processo saúde-doença vocal seja muito diferente daquela dos fonoaudiólogos!).

A voz transforma e é transformada pelo sujeito nos diversos contextos sociais em que ele participa, seja como pessoa ou como profissional. Na Fonoaudiologia, pode-se dizer que avanços significativos ocorreram para que a voz do professor possa ser considerada como um dos primeiros e mais importantes elos de relação professor-aluno, aspecto primordial na relação educativa e um dos principais recursos/instrumentos de trabalho docente. Além de aprofundar os estudos na perspectiva das significações, usos e funções da voz no campo do trabalho, é preciso buscar avançar ainda mais, no sentido de integrar esses estudos a pesquisas sobre a voz nos contextos de vida familiar e social os quais incorporem outras dimensões do sujeito, da sua qualidade de vida e dos seus contextos cotidianos para, dessa maneira, possibilitar somar, à dimensão e ao caráter "instrumental" da voz, também as dimensões e os caracteres constitutivos e expressivos da subjetividade que se dão no encontro e na integração sujeito/ voz no contexto de vida diária

No que diz respeito ao professor, há que se buscar conhecê-lo como um sujeito integral, . a partir da sua singularidade e das especificidades dos grupos sociais e profissionais dos quais faz parte, bem como das percepções que possui acerca da sua voz/saúde vocal, das relações que estabelece com a voz nos seus contextos cotidianos e realidades da sua qualidade de vida, considerando-o como sujeito social e trabalhador.

Por isso, é preciso considerar que a voz - ainda que alterada (disfônica) - se faz presente no embate professor-aluno, nas relações sociais do professor com a comunidade escolar, com a sua família, com os vizinhos e comunidade do local onde reside e por onde transita, com seus 
amigos. Enfim, nos diversos contextos interativos/comunicativos que se estabelecem no seu cotidiano de vida - trabalho e vida privada - sua voz está ali, presente na mediação afetiva e na intersubjetividade, sofrendo os impactos dos desejos, das intenções, dos interesses, das emoções, das tensões, dos conflitos, das diferenças, dos sentimentos contraditórios e da qualidade das relações dialógicas e vínculos que se constituem... - ou não!

Recorro MINAYO (1997-c) para finalizar este capítulo, destacando que o grande desafio da saúde coletiva está em em assumir essa concepção mais abrangente do processo saúde-doença (neste caso, processo saúde-doença vocal) que integre as políticas sociais, os contextos sociais, as condições e qualidade de vida, e a sensibilidade para a diversidade cultural e para as subjetividades que lhe são inerentes. 


\section{CAPÍTULO 2}

\section{OBJETIVOS}

\section{OBJETIVO GERAL:}

Investigar as relações entre qualidade de vida e voz/saúde vocal do professor.

\section{OBJETIVOS ESPECÍFICOS:}

1) Avaliar a qualidade de vida de professores e relacionar com os aspectos que interferirem no processo saúde/doença vocal desses sujeitos/trabalhadores.

2) Avaliar as implicações/impacto da voz sobre a qualidade de vida de professores.

3) Conhecer e identificar as necessidades, sentimentos, funcionalidades e representações que subjazem e permeiam as relações entre o sujeito e sua voz/saúde vocal nos contextos implicados no seu cotidiano e qualidade de vida. 


\section{CAPÍTULO 3}

\section{MÉTODO}

\section{1) DELINEAMENTO DA PESQUISA}

Neste trabalho, voz e linguagem são compreendidas de forma relacionada. E tal maneira de compreender a voz/linguagem encontra-se fundamentada nos estudos de perspectiva sócio-cultural de Vygotsky e na dialogia de Bakhtin. Voz e linguagem são consideradas a partir de uma dimensão constitutiva do sujeito com implicações sobre ele e sua realidade; ao mesmo tempo, observa a dimensão sócio-culturalmente constituida que sofre as implicações das interações, dos contextos sociais, da cultura e da qualidade de sua vida.

Nesse sentido, voz e saúde vocal serão consideradas e investigadas relacionadas ao sujeito e aos contextos da sua vida cotidiana, compreendidas sob uma perspectiva dinâmica, que incorpore a subjetividade, as interações, as condições e organização do trabalho e da vida privada, as percepções, os significados, enquanto social, cultural e historicamente construídos; bem como as maneiras de o sujeito relacionar-se consigo, com outros e com a sua própria realidade e qualidade de vida.

O objeto de estudo desta pesquisa é a saúde vocal do professor, como um construto da subjetividade e qualidade de vida desse sujeito/trabalhador. Neste estudo entende-se a saúde vocal não somente como presença/ausência de uma alteração de voz, mas numa perspectiva ampla, relacionada às necessidades do trabalho docente, às expectativas do sujeito sobre a vida, às funcionalidades da voz em sua realidade e contextos cotidianos, às possibilidades de expressão do sujeito e às relações da voz com a sua auto-imagem e auto-estima. 
Por isso, busco estratégias que possibilitem conhecer a realidade de vida do professor e a sua saúde vocal tomando como referência a sua própria percepção, considerando-se que a realidade vivida é também a realidade representada. A opção metodológica é orientada no sentido de contemplar a subjetividade do professor como eixo primordial no levantamento dos dados sobre a sua realidade e das relações desta com sua saúde vocal.

Este estudo segue uma abordagem qualitativa, pois esta trabalha com um universo de significados, motivos, aspirações, crenças, valores e atitudes que correspondem a um espaço mais profundo das relações e ações humanas, e considera que o fenômeno ou o processo social tem que ser entendido nas suas determinações culturais e transformações dadas pelos sujeitos. A metodologia qualitativa possibilita a aproximação e o conhecimento, ainda que imperfeitos, da complexidade e da suntuosidade que é a vida dos seres humanos em sociedade, abordando o conjunto de expressões humanas constantes nas estruturas, processos, sujeitos, representações e no próprio dinamismo da vida individual e coletiva, com toda a riqueza de significados dela transbordante (MINAYO, 1997-a).

Tomando como referência os dados das percepções e representações dos sujeitos da pesquisa, espero recuperar o professor como um sujeito social e trabalhador, em relação constitutiva com o mundo e consigo mesmo, na vida social, uma vez que as percepções e representações são manifestações da subjetividade que incorpora dimensões cognitivas, afetiva e social dos indivíduos. São produtos sociais que se formam nas interações, sempre relacionadas com as ações e com o lugar social dos sujeitos, também compondo suas práticas (FRIEDMAN, 1994; GUARESCHI e JOVCHELOVTTCH, 2000). Assim as percepções e representações possuem duas óticas complementares - como campo estruturado e pensamento socialmente construído; e como estruturante e pensamento constituinte.

Como indica SILVEIRA (2000), quando uma professora em atividade escolar se manifesta a respeito de sua escola ou de um projeto específico, ela está relatando a "realidades" vivenciadas - a de sua escola e a sua própria - e esse relato manifesto será o referencial da realidade vivida.

Nesta pesquisa utilizo fontes de dados de caráter quantitativo e qualitativo que se complementam numa integração de enfoques a qual, segundo WESTPHAL (2000), é necessária para dar conta da subjetividade e dos aspectos objetivos do conceito de qualidade de vida. Tal integração visa enriquecer a interpretação e a compreensão da realidade do fenômeno 
em estudo, na sua complexidade (LUDKE e ANDRE, 1986; PATTON, 1987 e JANESICK, 1993).

O Comitê de Ética em pesquisa da Faculdade de Saúde Pública da Universidade de São Paulo - COEP analisou e aprovou, em 13/11/2001, o Protocolo de Pesquisa de $n^{\circ} 588$, referente a essa pesquisa.

Essa pesquisa desenvolve-se se em três momentos (fases) e envolve recursos e instrumentos que possibilitam, ao mesmo tempo, fornecer os dados necessários e favorecer, aos sujeitos envolvidos, experiências de percepção e de reflexão. Cada uma dessas fases será descrita a seguir:

- Fase de planejamento - permitiu os contatos iniciais com as comunidades escolares, a partir do que obtive informações essenciais que possibilitaram eleger a população de estudo para a pesquisa. Essa fase, realizada nos meses de abril e maio de 2002, constou de contatos pessoais e telefônicos com representantes de Núcleos locais, Diretoria Regional de Ensino, associação de docentes (APEOESP) e secretarias ou diretorias das escolas estaduais de Rio Claro.

- Primeira fase - levantamento de dados, correspondente aos momentos de aplicação dos questionários.

- Segunda fase - levantamento de dados, correspondente à realização do grupo focal. 


\section{2 - FASE DE PLANEJAMENTO DA PESQUISA}

Os dados obtidos envolveram a listagem de todas as Escolas Estaduais de Rio Claro, nivel de ensino a que se destina cada escola (Fundamental ou Médio), perfil da comunidade a que atende, problemas e dificuldades enfrentadas pelos professores e número de professores em cada escola. Foram identificadas 24 Escolas Estaduais, sendo oito de Ensino Fundamental de $1^{\mathrm{a}}$ à $4^{\mathrm{a}}$ séries; 12 escolas de Ensino Fundamental de $5^{\mathrm{a}}$ à $8^{\mathrm{a}}$ séries e quatro escolas de Ensino Médio.

Assim, optei por focalizar nesta pesquisa os professores de Ensino Médio. Tal opção fundamenta-se pela possibilidade de envolver a totalidade das Escolas Estaduais de Ensino Médio de Rio Claro. Há poucos estudos fonoaudiológicos direcionados a essa parcela da população docente, pois a maioria dos mesmos focaliza professores de Educação Infantil e Ensino Fundamental.

Além disso, considerei que os cursos de Ensino Médio são oferecidos em períodos diurnos e noturnos, o que aumentariam as possibilidades de encontrar sujeitos que lecionassem em dois ou três periodos, por vezes até em diferentes escolas e que, portanto, estariam mais expostos às implicações do processo de trabalho sobre a sua vida e sua saúde.

A opção pelo Ensino Médio também visa evitar recair sobre um corpus de sujeitos com especificidades de riscos vocais previamente estabelecidas, o que ocorreria caso a opção fosse pela educação infantil ${ }^{1}$.

Entendo que a opção pelo Ensino Médio não desmerece, em relação ao Ensino Fundamental, os aspectos de demanda vocal elevada, desgaste emocional na manutenção da disciplina e atenção dos alunos, competição sonora e abuso vocal que ocorrem no uso profissional da voz docente; pois as informações obtidas durante a fase de planejamento da pesquisa demonstram que nos dois níveis de ensino há queixas explícitas de professores quanto à ausência de limites, desrespeito e desinteresse dos alunos, além de desamparo e falta de apoio e de participação da família na educação geral e formal. No Ensino Médio ocorrem, mais

\footnotetext{
${ }^{4} \mathrm{Na}$ Educação Infantil há riscos de abuso vocal inerentes à dinâmica do uso da voz na relação comunicativa que se estabelece entre mulheres (as professoras) e crianças, já que os dois grupos possuem caracteristicas vocais semelhantes (vozes mais agudas) que predispõem as professoras a uma competição vocal natural além da demanda de uso vocal.
} 
intensamente, as queixas de violência e agressividade dos alunos contra os professores, seus bens materiais (carro) e contra a própria escola, que contribuem para a ocorrência de confrontos e conflitos diretos e indiretos entre professores e alunos, os quais aumentam a tensão, a insegurança e o desgaste físico e emocional dos professores.

A escolha da escola pública como palco desta pesquisa visa aproximar a investigação das condições do trabalho docente nas características em que este se dá na maioria das regiões do país, já que a escola pública é a grande responsável pelo Ensino Fundamental e Médio no Brasil, como um todo. Em relação às questões de saúde vocal, tal escolha não exerce implicações, já que não há diferenças nos índices de prevalência de alterações vocais e lesões laríngeas, entre professores de escolas públicas e particulares (OLIVEIRA, 2001). Entretanto, aqui cabe uma sugestão: a de que estudos futuros contemplem, também, a investigação da qualidade de vida de professores de ensino médio de escolas particulares.

A existência de estudos anteriores realizados por CARNEIRO (1997 e 2001) no municipio de Rio Claro, focalizando morbidade, problemas e necessidades de saúde enfrentados por professores, também motivou o direcionamento da atenção da presente pesquisa aos professores de Ensino Médio. Assim, para complementar os resultados obtidos por aquela pesquisadora nesse mesmo município e para preencher a lacuna deixada pelos estudos fonoaudiológicos em saúde vocal do professor e, assim, contribuir para o conhecimento mais amplo da realidade e qualidade de vida, saúde e trabalho do professor desse nível de ensino, fiz esta escolha.

As informações obtidas a respeito das Escolas Estaduais de Ensino Médio de Rio Claro, durante a fase de planejamento da pesquisa, dizem respeito ao número de professores em cada escola e indicam questões que envolvem necessidades de toda a comunidade escolar, tais como: dificuldades financeiras e falta de recursos nas escolas; problemas de saúde dos professores como estresse, depressão e alterações de voz; além de violência, indisciplina, desrespeito, falta de limites e despreparo educacional dos alunos.

A seguir, algumas informações especificos de cada escola:

De um total aproximado de 238 professores de Ensino Médio estadual no município de Rio Claro, foi realizado cálculo estatístico de correção do número da população, a fim de determinar a amostragem desta pesquisa. O procedimento de amostragem utilizado foi o de amostragem estratificada proporcional (COCHRAN,1965; COSTA NETO, 1977), sendo os 
estratos representados pelas 4 escolas de ensino médio da cidade. $O$ erro amostral foi de 0,06 , e assim, a amostra foi composta como segue:

\begin{tabular}{ccc}
\hline Escola & N. $^{0}{ }^{0}$ Total de Professores & N. $^{{ }^{0}}$ de Professores na Amostra \\
\hline 1 & 74 & 40 \\
2 & 60 & 32 \\
3 & 82 & 44 \\
4 & 22 & 12 \\
\hline Total & $\mathbf{2 3 8}$ & $\mathbf{1 2 8}$ \\
\hline
\end{tabular}

O cálculo de correção para população finita determinou que participariam da primeira fase desta pesquisa 128 professores de Ensino Médio, sendo: 40 professores da escola 1 (27\%); 32 professores da escola 2 (36\%); 44 professores da escola 3 (29\%) e 12 professores da escola $4(8 \%)$.

\section{3 - SUJEITOS DA PESQUISA}

Constituem-se os sujeitos desta pesquisa 128 professores de Ensino Médio das Escolas Estaduais do município de Rio Claro (SP), em situação de trabalho; sendo 40 professores da escola um, 32 professores da escola dois, 44 professores da escola três e 12 professores da escola quatro.

A qualidade vocal não foi fator de exclusão, já que não se trata do objetivo desta pesquisa a avaliação fonoaudiológica das vozes dos professores. 


\section{4 - PRIMEIRA FASE DA PESQUISA (questionários)}

A primeira fase envolve o levantamento de dados por meio da aplicação de dois instrumentos específicos, os questionários QVV (Qualidade de Vida e Voz) de auto-avaliação das implicações/impacto da voz/saúde vocal sobre a qualidade de vida; e o WHOQOL/breve (World Health Organization Quality Of Life/ Breff), de auto-avaliação da qualidade de vida. Ambos os questionários, o QVV e o WHOQOL/Breve (QV), baseiam-se na subjetividade do professor e na sua percepção, interpretação e representação, e apresentam características que possibilitem sua mensuração.

A opção pelo uso destes dois instrumentos deveu-se aos fins a que se prestam, à pertinência com os objetivos desta pesquisa, à praticidade e facilidade na aplicação e à confiabilidade que oferecem - já que ambos foram testados e validados e se encontram em condições de serem utilizados no Brasil (FLECK et al, 1999 e 2000; BEHLAU, 2001).

$\mathrm{O}$ questionário $\mathrm{QVV}{ }^{2}$ refere-se a uma adaptação e tradução da fonoaudióloga Mara Behlau para o português, do VRQOL (Voice Related Quality Of Life), desenvolvido por Hogikyan e Sethuraman. O protocolo QVV envolve apenas 10 itens e relaciona qualidade de vida e voz envolvendo os domínios Físico, Sócio-Emocional e Global - esse último sintetizando os dois primeiros. Para o cálculo dos domínios padronizados da QVV, foram utilizadas as seguintes expressões, propostas por HOGIKYAN e SETHURAMAN (1999) e BEHLAU (2001 e 2001-b):

1) Sócio-emocional $=100-\frac{(Q .4+Q .5+Q .8+Q .10-4)}{16} \times 100$.

2) Funcionamento físico $=100-\frac{(Q .1+Q .2+Q .3+Q .6+Q .7+Q .9-6)}{24} \times 100$

3) Global $=100-\frac{(Q .1+Q .2+Q .3+Q .4+Q .5+Q .6+Q .7+Q .8+Q .9+Q .10-10)}{40} \times 100$

\footnotetext{
${ }^{2}$ Consta dos anexos deste projeto de pesquisa - Anexo 1
} 
O questionário WHOQOL/Breve $e^{3}$ é um protocolo de avaliação de qualidade de vida (QV) que aborda aspectos mais amplos da mesma envolvendo 4 domínios: Físico, Psicológico, Meio Ambiente e Relações Sociais. Cabe ressaltar que, aqui, não há um domínio global. Este protocolo é proposto pela Organização Mundial da Saúde (OMS), reduzido a 26 questões a partir de um questionário maior, desenvolvido dentro de uma perspectiva transcultural para uso internacional, o WHOQOL-100, que envolvia 100 questões. O WHOQOL/breve foi traduzido para o português pelo GRUPO WHOQOL, a mesma comissão de profissionais e pesquisadores que participou da elaboração do protocolo que o originou (GRUPO WHOQOL, 1998; FLECK et al, 1999 e 2000; MINAYO, HARTZ e BUSS, 2000).

Para os domínios padronizados da QV (WHOQOL/breve), foram usadas as expressões que se seguem, conforme proposto na literatura:

1) Físico $=\frac{\left(\frac{(6-Q .3)+(6-Q .4)+Q .10+Q .15+Q .16+Q .17+Q .18}{7} \times 4-4\right)}{16} \times 100$

2) Psicológico $=\frac{\left(\frac{Q .5+Q .6+Q .7+Q .11+Q .19+(6-Q .26)}{6} \times 4-4\right)}{16} \times 100$

3) Relações sociais $=\frac{\left(\frac{Q .20 . b+Q .21+Q .22}{3} \times 4-4\right)}{16} \times 100$

4) Meio ambiente $=\frac{\left(\frac{Q .8+Q .9 . b+Q .12+Q .13+Q .14+Q .23+Q .24+Q .25}{8} \times 4-4\right)}{16} \times 100$.

Os domínios padronizados do QVV e do QV apresentam valores variando entre 0 e 100 , sendo piores os mais próximos de 0 e melhores os mais próximos de 100. Dessa forma um sujeito que tenha valor igual a 50 para determinado domínio pode ser considerado mediano para esse domínio.

\footnotetext{
${ }^{3}$ O protocolo encontra-se nos anexos deste projeto de pesquisa - Anexo 2.
} 
Os dois questionários foram aplicados durante o mês de junho de 2002, época em que se espera que os professores estejam mais sensibilizados quanto às suas questões de saúde, já que esse mês configura-se como um dos picos de maior ocorrência de doenças e afastamentos de professores por licença médica (CARNEIRO, 1997).

Também foram investigados outros aspectos, através de questões extras, constantes nos itens VIII e IX, pertencentes ao protocolo SF-36 (Medical Outcomes Study Short-Forms). O SF-36 é um questionário auto-aplicável que reúne 36 questões de múltipla escolha relacionadas à saúde geral. É um instrumento utilizado para pesquisar o estado de saúde funcional e o bem-estar de pessoas, na prática clínica, em avaliações de políticas de saúde e em pesquisas com a população em geral; e está dividido em oito domínios: funcionamento físico, limitações fisicas, limitações emocionais, funcionamento social, dor, saúde mental, vitalidade e percepções da saúde (WARE e SHERBOURNE, 1992). As questões referentes aos itens VIII e IX foram anexadas aos questionários a serem respondidos pelos professores, mas serão utilizadas apenas como fontes de dados complementares e podem ser visualizados no ANEXO 3.

Relatos de considerações gerais sobre as diferentes escolas e as situações de aplicação dos questionários configuram-se dados complementares e serão apresentados no capítulo de resultados.

Inicialmente, faço uma apresentação geral da amostra, por meio de análise descritiva das questões e utilizando tabelas de freqüência e de classes de freqüência, de acordo com a natureza da variável. Os resultados foram ilustrados por meio de gráficos de barras.

Posteriormente, apresento diagramas de "ramos e folhas" (HOAGLIN et al., 1991) para os domínios da QVV e da QV. Esses diagramas são a ordenação dos dados de forma programada para mostrar sua distribuição aproximada, dispersão, assimetria, curtose, agrupamento de valores e, principalmente, deteç̧ão de outliers (dados discrepantes) e sua localização quanto ao indivíduo, alertando para possiveis problemas não notados durante o estudo (por exemplo, professores com alguma característica distinta que interfira no domínio).

O próximo passo foi analisar a consistência dos domínios da QVV e da QV, por meio do cálculo do coeficiente Alpha de Cronbach (PEREIRA, 1999; SAS, 1999). O coeficiente Alpha de Cronbach foi calculado utilizando-se a expressão abaixo, sendo $\mathrm{k}$ o número de 
domínios; $\sum_{\mathrm{i}} \operatorname{Var}\left(\mathrm{Y}_{\mathrm{i}}\right)$ a soma da variâncias dos domínios; e $\operatorname{Var}\left(\sum_{\mathrm{i}} \mathrm{Y}_{\mathrm{i}}\right)$ a variância da soma dos domínios:

$$
\alpha=\left(\frac{\mathrm{k}}{\mathrm{k}-1}\right)\left(1-\frac{\sum_{\mathrm{i}} \operatorname{Var}\left(\mathrm{Y}_{\mathrm{i}}\right)}{\operatorname{Var}\left(\sum_{\mathrm{i}} \mathrm{Y}_{\mathrm{i}}\right)}\right)
$$

Para assegurar a validade desse coeficiente, foram calculados os coeficientes de correlação entre os domínios da QVV e entre os domínios da QV. No caso de variáveis medidas através de escores, a literatura consultada sugere ser melhor optar pelo cálculo do coeficiente de correlação de Spearman, que é não-paramétrico, ao invés do coeficiente de correlação de Pearson (CAMPOS, 1983; COSTA NETO, 1977; WALLER, 1979; SPIEGEL, 1993).

Após avaliar que os domínios da QVV e da QV foram consistentes para a amostra, foram realizados cálculos dos coeficientes de correlação de Spearman, agora entre os domínios da QVV e da QV. O coeficiente de correlação de Spearman também foi utilizado para avaliar a associação da Idade, do Número de períodos que o professor leciona e da resposta de Como avalia a própria voz, Como avalia a qualidade de vida e Quão satisfeito está com sua saúde, com os domínios da QVV e da QV, e com as respostas de outras questões complementares nãoenglobadas por esses instrumentos de avaliação.

Além disso, os domínios da QVV e da QV foram comparados, considerando o sexo e escola onde o indivíduo leciona. O teste de Wilcoxon (teste da soma das ordens) foi utilizado para efetuar a comparação entre os sexos, enquanto o teste de Kruskal-Wallis foi usado para comparar as escolas onde o professor leciona (CAMPOS, 1983; SAS, 1989; SPIEGEL, 1993; LEHMMANN, 1975). Para rejeitar a hipótese de igualdade entre os grupos foi considerado um nível mínimo de significância de 5\%, isto é, sempre que o nível descritivo de probabilidade foi menor ou igual a 0,05 rejeitou-se a hipótese de igualdade entre os grupos e, conseqüentemente, aceitou-se que existia diferença significativa entre eles ao nível de $5 \%$.

Ao final, utilizei a técnica das faces de "Chernoff", como um método exploratório para agrupar os indivíduos com características semelhantes em relação aos domínios da QVV, da QV e algumas questões específicas (auto-avaliação vocal, auto-avaliação da qualidade de vida 
e satisfação com a saúde). Essa técnica é um método gránico que permire representar observações no espaço k-dimensional. O objetivo é representar dados multivariados, sujeitos a uma importante, porém complexa relação, propiciando um caminho pelo qual o pesquisador pode rapidamente obter informações relevantes, bem como visualizar aqueles sujeitos que se mostrem interessantes para o aprofundamento das questões, na segunda fase desta pesquisa. $O$ método consiste em representar um ponto no espaço k-dimensional por um desenho de uma face cujas características são determinadas pela posição do ponto. Uma amostra de pontos (sujeitos) no espaço k-dimensional é representada por uma coleção de faces (CHERNOFF, 1973).

A partir da análise das faces de "Chernoff" fez-se a seleção dos professores convidados para participarem da segunda fase da pesquisa.

Cabe, ainda, destacar que todos os sujeitos envolvidos nessa pesquisa foram informados de sua natureza e do objetivo e de que esta não implicava em riscos aos participantes. A todos, thes foi assegurado o anonimato das informações. Após haver lido e explicado o termo de consentimento livre e esclarecido, coloquei-me à disposição para dirimir eventuais dúvidas. A todos foi garantida a possibilidade de negarem-se a participar da pesquisa, ou mesmo de mudarem de opinião a qualquer momento, sem nenhum tipo de sanção. Todos os professores assinaram o termo de consentimento e apenas dois sujeitos negaram-se a participar e foram respeitados em sua decisão. Após o Consentimento Livre e Esclarecido (ANEXO 6) deu-se a apresentação e aplicação dos questionários junto aos professores.

Estive sempre presente durante o momento em que os professores respondiam os questionários, a fim de esclarecer questões e dúvidas que porventura surgissem durante o processo de preenchimento. No momento da entrega dos questionários, conferia o preenchimento das respostas, solicitando a complementação de algum campo eventualmente deixado em branco por algum ato falho, solicitação esta à qual os professores respondiam prontamente. No momento da entrega do material, alguns professores teciam comentários comigo a respeito do processo. 


\section{5 - SEGUNDA FASE DA PESQUISA}

Esta segunda etapa visa adensar o conhecimento dos dados obtidos na primeira fase da pesquisa, destacando aquilo que se mostrou relevante e complementando aspectos não abordados ou que foram apenas parcialmente abordados nos dois instrumentos anteriormente citados. Visa ampliar os horizontes de análise e de interpretação da complexidade que envolve o tema em questão, respondendo, principalmente, ao terceiro objetivo dessa pesquisa.

Ao mesmo tempo, essa etapa refere-se ao levantamento de dados qualitativos acerca das percepções e representações dos professores, a ser realizado de maneira coletiva, por meio da técnica de grupo focal, cuja técnica é considerada muito valiosa em pesquisas, pelo seu baixo custo e pela rapidez com que oferece dados válidos e confiáveis - embora sua utilização por pesquisadores da área de saúde seja ainda relativamente recente, tendo se iniciado a partir dos anos 80 , sendo aplicada com maior intensidade nos últimos 10 anos.

O grupo focal é um tipo especial de grupo em termos de seu propósito, tamanho, composição e dinâmica; pode ser considerado como uma espécie de entrevista coletiva apoiada na interação entre os participantes para colher dados de tópicos fornecidos pelo pesquisador (CARLINI-COTRIM, 1996).

A técnica de grupo focal utiliza a formação de grupos de discussões planejadas como facilitadores da expressão de características psicossociológicas e culturais dos participantes, tais como percepções, valores, atitudes, idéias e representações, num ambiente permissivo e não-constrangedor (WESTPHAL, BÓGUS e FARIA, 1996). O grupo focal é recomendado como possibilidade de pensar coletivamente uma temática da vida das pessoas, bem como de observar as controvérsias e problemas a ela inerentes.

As vantagens do grupo focal e a qualidade dos dados por ele oferecidos, comparado a entrevistas individuais, são apontadas por diversos autores, como MENEGON (1999) e OLIVEIRA e WERBA (2000), por apresentarem uma situação mais próxima dos contextos interacionais cotidianos e propiciarem uma interanimação dialógica povoada por um contingente mais rico de vozes em que a negociação de versões e posicionamentos é mais visível, bem como pela oportunidade de se estabelecer uma intensa troca de idéias sobre 
determinado tópico, discutindo e aprofundando dados em conjunto num período limitado de tempo.

Os grupos focais possibilitam emergir percepções e representações individuais e coletivas e, assim, a opção por esse recurso é justificada pela concepção de sujeito que é assumida nesta pesquisa: entende-se o professor como um sujeito social e um trabalhador que, como tal, está inscrito numa realidade social, cultural e histórica definida; daí suas colocações e respostas comportarem sua história pessoal e social, com manifestações de tendências do seu grupo de pertença (SPINK, 2000).

Assim, os grupos focais possibilitam ouvir os sujeitos num contexto de relações, confronto de valores, idéias, opiniões, experiências e trocas sociais entre os seus colegas de profissão, o que se dá pela linguagem, no diálogo e participação ativa dos professores, nas referências dos sujeitos e naquilo com que concordam ou a que se opõem.

Mais do que simplesmente coletar dados para a pesquisa, busca-se oferecer aos sujeitos oportunidade de reflexão e tomada de consciência de uma realidade - sobre o próprio trabalho, a vida e a saúde vocal nesses contextos -, oportunidade a que os professores não estão acostumados e de que não dispõem no cotidiano, conforme afirma CARNEIRO (2000). Ao mesmo tempo, essa estratégia, ao levantar os dados, incentiva o diálogo entre os professores a fim de que estes possam, apoiados nessa atividade dialógica e reflexiva, responder à pesquisadora com um discurso que permite emergirem aspectos pessoais e coletivos dessa categoria profissional, os quais poderiam passar desapercebidos ou permanecer latentes em uma entrevista individual.

Um grupo focal é formado por 6 a 15 pessoas com um traço comum. No caso desta pesquisa, o traço comum é ser um professor de Ensino Médio da rede Estadual de Ensino de Rio Claro. Assim, esse grupo focal foi constituído por 12 professores(as); sorteados(as) dentre um total de 27 sujeitos selecionados a partir da análise das "Faces de Chernoff", tendo como critério o fato de apresentarem baixos scores no QVV, portanto aqueles sujeitos que sofrem grande impacto negativo da voz na qualidade de vida.

Os professores selecionados foram convidados pessoalmente por mim para participar do grupo focal, com aproximadamente 10 dias de antecedência ao encontro, o qual se deu numa manhã de sábado em um local reservado para essa finalidade. O local era neutro e acessível aos participantes, na região central da cidade, um lugar não movimentado, constituído 
de uma sala ampla com banheiros e com uma grande mesa oval ao centro e cadeiras, onde os participantes se acomodaram. O local e mobiliário disponibilizados para a pesquisa estavam, assim, em conformidade com o que preconiza CARLINI-COTRIM (1996), que também propõe oferecer algum incentivo aos participantes, como um almoço ou sorteio de presentes, a fim de obter maior sucesso no recrutamento. Todos os professores convidados compareceram no horário combinado e permaneceram durante o tempo previsto - o grupo focal teve duas horas de duração. No decorrer do grupo focal, foi servido um café da manhã e, ao final, os professores foram presenteados.

Segundo CARLINI-COTRIM (1996), a condução do grupo focal se dá a partir de um roteiro de tópicos, sendo entre 2 e 4 , elaborados a priori e relacionados com as questões de investigação da pesquisa, com a proposta de desenvolver uma discussão "focada"em temáticas específicas. Os tópicos não devem ser propostos em forma de perguntas, mas sim no formato de uma solicitação para comentar ou descrever algo.

No grupo focal dessa pesquisa, a temática proposta para discussão é derivada da análise dos resultados dos questionários QVV e QV e refere-se aos aspectos do cotidiano e da qualidade de vida do professor que tocam em questões relacionadas ao trabalho docente, às relações sociais, aos seus momentos de lazer e aos seus sentimentos na busca de relações com a voz/saúde vocal. Foram elas:

1) A relação voz/trabalho docente

2) A vida social do professor e a saúde fisica / emocional e vocal

- nas relações familiares

- nas relações de amizade

- nas relações de trabalho

3) A voz e os sentimentos

4) A voz nos mo momentos de lazer

5) Para quê e para quem a voz?

Participaram do grupo focal: eu, no papel de moderadora; uma fonoaudióloga, no papel de relatora; uma psicóloga, no papel de observadora e os professores convidados. No papel de moderadora, a mim coube receber os participantes, expor os objetivos da pesquisa, explicar a 
forma de funcionamento do grupo, conduzir a apresentação dos participantes, propor os temas para a discussão, solicitar esclarecimentos ou aprofundamentos de pontos específicos, favorecer um ambiente propício à expressão de todos, conduzir o grupo para o tópico seguinte quando um ponto estivesse suficientemente explorado e finalizar o grupo conduzindo a última rodada de discussões (CARLINI-COTRIM, 1996). À relatora coube anotar os principais pontos discutidos cujas anotações poderiam servir de referência e auxílio à moderadora, na identificação de aspectos a serem aprofundados ou retomados durante o grupo. À observadora coube atentar para a conduta do grupo e anotar acontecimentos-chave.

O grupo focal foi gravado por meio de filmagem com a única finalidade de servir de suporte para o trabalho de transcrição das discussões e para a análise. As imagens do grupo focal não serão utilizadas com nenhuma outra finalidade.

O trabalho de análise dos dados do grupo focal toma por base a análise de conteúdo, um conjunto de técnicas proposto por BARDIN (1977) e citado e recomendado por autores, como MINAYO (1997-b) e TRIVIÑOS (1995), para o estudo das comunicações, motivações, atitudes, valores, crenças ou tendências, seja no discurso individual ou grupal.

O trabalho de análise de conteúdo - análise temática - na presente pesquisa foi realizado a partir dos seguintes procedimentos: a pré-análise, a exploração do material e o tratamento dos resultados (BARDIN, 1977). Na pré-análise foram realizadas várias leituras e o estudo do material gravado e transcrito, permitindo aflorar os sentidos e descobrindo impressões e orientações para a análise. A exploração do material possibilitou identificar temas e conjuntos temáticos, bem como selecionar trechos significativos e identificar conteúdos e núcleos de sentidos que orientaram recortes e agregações dos episódios discursivos na organização do material em categorias temáticas que se referem às representações emergentes. O.tratamento dos resultados e aprofundamento da análise se deu pela inferência e interpretação que relaciona os dados das representações obtidas no grupo focal com o conhecimento acumulado anteriormente e com o referencial teórico que embasa a pesquisa (BARDIN, 1977; TRIVIÑOS, 1995; MINAYO, 1997-b).

Para BARDIN (1977), a análise não se limita ao conteúdo. Assim, na análise realizada nesta pesquisa busquei considerar os conteúdos e as representações subjacentes ao que está manifesto, expressos nas tendências, nas determinações, nas versões contraditórias, na organização do discurso ou nas pistas do investimento afetivo presente. A observação dos 
processos de interanimação dialógica desenvolvidos no grupo focal possibilitou atentar, também, para a seqüência das práticas discursivas, os gestos, as posturas, as expressões faciais, os silêncios ${ }^{1}$ - já que a dialogia não se esgota nem se encerra no diálogo (SPINK e MEDRADO, 1999); e tais dados serão utilizados como informação complementar sempre que se fizerem relevantes para a análise.

A análise de conteúdo que realizo nessa pesquisa assume, em conformidade com o proposto por REY (2002), uma conotação construtivo-interpretativa, orientada para a construção de indicadores que transcendem a codificação e a redução do conteúdo em categorias restritivas, permitindo a utilização de elementos singulares, implícitos e indiretos na construção do processo construtivo-interpretativo.

\footnotetext{
${ }^{\dagger}$ Mesmo o silêncio significa; e, aqui, considera-se que o silêncio não é ausência de palavras, já que em condições dadas fala-se para não dizer ou mesmo para impedir que coisas sejam ditas; o silêncio é aquilo que é apagado, colocado de lado, excluido (ORLANDI, 1997).
} 


\section{Capítulo 4}

\section{RESULTADOS E DISCUSSÃO}

Esse capítulo apresenta os resultados da primeira fase da pesquisa (referente à aplicação dos questionários) e da segunda fase (referente ao grupo focal).

Entretanto, antes da apresentação dos resultados das respostas aos questionários, peço licença ao leitor para iniciar esse capítulo com um relato dos fatos ocorridos durante a primeira fase, na situação de aplicação dos questionários. Tal relato engloba os dados das minhas observações e percepções acerca do cotidiano das escolas, das dinâmicas sociais que elas encerram e de enfrentamento de seus problemas. Comporta informações importantes e dados que, apesar de complementares, constituem-se como elementos singulares e indiretos que contribuem para a interpretação da realidade e compreensão das condições e organização do trabalho docente nas diferentes escolas, considerando-se que, na pesquisa qualitativa, a informação que aparece nos momentos informais da pesquisa é tão legítima como aquela procedente dos instrumentos utilizados; e que a construção da informação, nesse tipo de pesquisa, não se apóia somente na coleta de dados, mas segue o curso progressivo e aberto de um processo de construção e de interpretação que acompanha todos os momentos da pesquisa (REY, 2002). 


\section{RESULTADOS DA PRIMEIRA FASE DA PESQUISA}

\section{1 - CONSIDERAÇÕES SOBRE AS ESCOLAS E A SITUAÇÃO DE APLICAÇÃO DOS QUESTIONÁRIOS}

Durante o mês de junho/2002 foi realizada a primeira fase desta pesquisa, após meu contato inicial com a direção e coordenação pedagógica de cada escola, quando, então, expus os objetivos, a finalidade e a proposta metodológica do trabalho, solicitando o agendamento de um horário para uma reunião com grupos de professores, a fim de viabilizar a coleta de dados da pesquisa. O horário preferido e disponibilizado pelas escolas foi o de Horário de Trabalho Pedagógico Coletivo (HTPC), semanalmente destinado a atividades e reuniões de professores.

Participei de diversas reuniões de HTPC, em diferentes horários, visando obter o número necessário de sujeitos participantes. Em geral, sempre fui muito bem recebida pela diretoria, coordenação pedagógica e pela grande maioria dos professores, que se demonstraram interessados pelo tema e, prontamente, se dispuseram a participar e colaborar com a pesquisa. Nos meus encontros com os professores, deu-se a explicação da pesquisa, seguida do consentimento införmado e esclarecido. A seguir, o relato das situações em cada escola

\section{Escola 1}

É a maior em espaço e estrutura física, mas apresenta-se deteriorada, e mal iluminada, jardins internos descuidados, com plantas e galhos secos jogados sobre o gramado e ladeando a passarela de acesso aos prédios. $O$ piso de cimento nas áreas externas, de ladrilho avermelhado nos corredores e de soalho no interior das salas de aula, apresenta-se totalmente desgastado, sem brilho e com tábuas soltas e buracos que possibilitam tropeços. Há algumas vidraças 
quebradas. As paredes da escola encontram-se pichadas, com desenhos ou pinturas realizados pelos alunos, ocupando toda a extensão das paredes do pátio interno e áreas externas. A característica de tais desenhos, sua temática, bem como cores fortes e escuras empregadas, provocam um efeito estético carregado no ambiente.

A sala de reunião dos professores localiza-se no final de um corredor e é bastante ampla, porém a distribuição do mobiliário não oferece aproveitamento harmonioso do espaço. Logo à entrada, há um grande armário de ferro e uma mesa retangular com 4 cadeiras onde alguns professores se acomodam para preencher seus diários de classe e realizar atividades paralelas durante a reunião.

No chão de soalho ao centro da sala, há um grande buraco preto, que deixa à mostra o contra-piso todo queimado. $\mathrm{O}$ revestimento de tábuas daquele local foi consumido pelo fogo ateado por alunos numa invasão ocorrida durante um final de semana, quando ali fizeram enorme fogueira com os mapas escolares. Os docentes entram e saem da sala passando ao lado ou mesmo pisando sobre tal buraco, sem se demonstrarem incomodados; e nem mesmo se observa alguma iniciativa por parte do corpo docente/administrativo em escondê-lo ou restaurá10. A impressão provocada é chocante, especialmente se consideradas as representações de violência, agressividade e desrespeito às quais a escolha do local e o próprio ato dos alunos remetem.

$O$ fato de o corpo administrativo/docente manter aquelas marcas visiveis no chão durante meses, despertam sentimentos negativos tais como o descaso para com o patrimônio da escola, a impressões de insensibilidade do professor que pisa aquele chão aparentemente sem se incomodar, provavelmente já acostumado e "anestesiado" com a violência cotidiana na escola; também leva à impressão de que aquelas marcas são deixadas ali, na sala dos professores, para que eles próprios possam se lembrar, diariamente - e várias vezes por dia -, do contexto de agressividade e de violência em que se dá o seu trabalho, bem como de "quem são" os seus alunos. Expressão de vitimização ou realidade nua e crua? Seja como for, pude evidenciar que a expressão da criminalidade e da violência social e escolar estão, assim, "perfeitamente" integradas ao cotidiano do professor da Escola 1.

Nessa sala não há bebedouros nem bebidas como café ou chá, não há plantas nem enfeites que possam traduzir qualquer cuidado com a decoração do ambiente, exceto um dos vitrôs de uma parede enfeitados com tiras de papel crepom, nas cores da bandeira brasileira, 
alusivos ao momento em que se realizava a "Copa do Mundo de Futebol". Abaixo dos vitrôs, dois sofás, defronte a uma outra mesa, essa grande e retangular, ladeada por várias cadeiras, em que a maioria dos professores se acomoda durante a reunião. Sobre a mesa de reunião, o único objeto decorativo - uma minúscula cestinha de sucata de garrafa plástica com algumas pequenas flores de papel crepom; esse objeto passava de mão em mão dos professores durante a reunião, que assim se distraíam ocupando suas mãos e seu olhar.

$\mathrm{Na}$ outra parede, uma grande lousa com cartazes pregados e anotações com giz e, ao fundo da sala há três sofás, nos quais alguns professores fumantes se acomodam durante a reunião, em cuja parede fronteira uma lousa grande contém vários avisos correspondentes a justificativas de faltas de alunos que se encontram em licença médica por estarem doentes, internados em hospitais ou em licença-maternidade. A mesa e os sofás parecem ser novos, pois estão em bom estado de conservação.

Da relação entre os profissionais, observa-se que a comunicação é truncada, pobre e ineficiente em diversos níveis.

No primeiro dia do levantamento de dados da pesquisa na Escola 1, pude observar que a diretoria não havia comunicado a coordenação pedagógica sobre o agendamento realizado com a pesquisadora, assim como uma coordenadora não comunicara à outra sobre o agendamento para o HTPC do dia seguinte, fazendo com que eu tivesse que retornar inúmeras vezes, inclusive assistindo a algumas reuniões de rotina.

Ao chegar na sala, na ocasião de uma dessas reuniões de HTPC à noite, encontrei os professores exaltados, discutindo. Observei que os colegas iam chegando e os professores não olhavam quem adentrava a sala, os quais se acomodam onde houvesse lugar, sem olhares nem sorrisos e raros eram os cumprimentos. Àqueles que chegam atrasados, não foi passada nenhuma pauta da reunião em andamento, sendo que alguns procuraram se inteirar com os colegas ao seu lado, enquanto outros se acomodaram à mesa e aguardaram o seguimento da reunião. Diversos professores permaneceram realizando atividades paralelas ou até mesmo conversando durante a explanação de um colega. Em geral, os professores parecem não notar, não se incomodar e até mesmo ignorar minha presença na sala.

A temática da reunião causa um enorme mal-estar geral causado por um "boato" de que o período noturno de aulas naquela escola seria fechado e as classes noturnas seriam distribuídas em três diferentes e distantes escolas estaduais do município. Havia professoras 
muito exaltadas, irritadas e revoltadas, falando alto, gritando e batendo na mesa enquanto expressam seu sentimento de vergonha por serem professoras daquela escola estigmatizada e condenada. Sentiam-se desrespeitadas, já que nem o corpo docente nem os representantes da escola haviam sido consultados ou notificados sobre o assunto, enquanto que o tema (o "boato") já estava sendo tratado em reuniões envolvendo representantes de associação docente e pessoal administrativo/político do setor educacional local e regional. Exprimiam o desgaste em que se encontravam, sentindo-se "no fundo do poço" perante a situação de desmonte e de sucateamento do ensino público e da própria escola e à tentativa desesperada de sobrevivência daquela escola em manter em funcionando o seu período noturno, tido como inviável. Revoltavam-se com a situação de tomarem conhecimento das informações que lhes dizem respeito direto através de terceiros, queixando-se de uma comunicação e diálogo que ocorre politicamente mas que não envolve o professor, o maior interessado no assunto. A maioria dos professores (as) demonstravam-se irrequietos, começam a distrair-se e se empenharem em outras atividades como uma "fuga" à tensão criada durante a reunião, mas ninguém interveio sugerindo ações concretas ou a mudança de assunto. Entretanto, é interessante observar a diferença de gênero no enfrentamento dessa problemática. Os professores homens mantiveramse aparentemente calmos, tranqüilos e otimistas, sem atribuir importância ao tal "boato" e manifestam-se somente no sentido de acalmar as professoras até que obtivessem confirmação dos fatos, ao que não obtiveram resposta.

Nesse contexto tenso, constrangedor e desfavorável; o diretor aproveitou o desconforto geral em relação ao tema (e, provavelmente, mais com a intenção de mudança de assunto), solicitou a interrupção das discussões e apresentou a pesquisadora para a coordenadora pedagógica e ao grupo de professores. Alguns professores sequer se viraram ou levantaram a cabeça para olhar para o diretor e para a minha pessoa. A maioria dos professores atentou para as colocações, talvez mais como uma possibilidade de finalizar a temática anterior do que propriamente interessados na proposta da pesquisa. Duas professoras negaram-se a participar, no que foram respeitadas. Todos os demais presentes participaram prontamente. As duas pessoas que se negaram a participar prosseguiram com as discussões paralelamente, enquanto os demais colegas preenchiam o questionário. Alguns professores solicitaram ajuda para compreender algumas questões, outros vieram fazer comentários sobre suas questões de saúde 
no momento de entregar o questionário. Logo após, findo o tempo da reunião, os professores retiraram-se diretamente para as classes, a fim de dar aulas.

Cabe aqui refletir que, muitas vezes, são contextos assim que o professor vivencia minutos antes de entrar em sala de aula; assim é ocupado o tempo de que o professor dispõe antes de fazer o uso profissional da sua voz: uma hora de reunião de HTPC sob tensão e de revolta, com atos e sentimentos de desrespeito de toda ordem e de todos os níveis hierárquicos, com ameaças à existência/manutenção do próprio trabalho e da condição de trabalhador, com acaloradas discussões que demandam grande desgaste psíquico e vocal... Seria um contexto desses, pertinente à realização dos exercícios de "aquecimento vocal" comumente orientados nas ações de saúde vocal destinadas ao professor? Como esperar a realização de exercícios vocais num contexto deste? Como esperar que o professor vá realizar um "adequado" uso da voz - livre de esforço ou de tensão, dentre outras coisas - em sala de aula, tendo passado por uma reunião dessas? Há, certamente, outros aspectos implicados no cotidiano de vida e trabalho docente que influenciam as condições de uso da voz e a sua saúde vocal do professor e que escapam às expectativas fonoaudiológicas bem como às temáticas de higiene vocal e de comportamento vocal.O singelo exemplo dessa reunião de HTPC permite considerar que há problemas e questões sociais, psico-emocionais, interacionais e comunicativas gritantes, naquelas condições e maneiras como o trabalho é organizado, os quais podem resultar em sofrimentos e comprometimentos à saúde geral, psíquica e vocal daquele grupo de trabalhadores professores.

Participando uma única vez de uma dessas reuniões, saí desgastada e conclui que o ambiente físico, psicossocial, relacional e comunicativo nessa escola é totalmente desfavorável ao convívio e ao trabalho saudável. Ao atravessar o portão da escola (defronte à rua escurecida pelas muitas árvores da avenida que escondem os postes de iluminação pública, já no horário de entrada dos alunos do período noturno) deparo-me com uma viatura da polícia estacionada em frente ao portão de entrada de alunos e professores, com seu sinaleiro luminoso ligado e quatro policiais em seu interior. Aparentemente a tensão e os sinais de perigo/violência iminente permanecem . E isso leva a pensar: $\mathrm{E}$ como fica o professor, que convive com isso diariamente?

Quatro dias depois retornando à escola, em novo agendamento em horário de HTPC, ainda se discutia o mesmo assunto. Entretanto, por volta de 20 minutos antes de findar a 
reunião uma profissional supervisora adentrou a sala e esclareceu que estivera junto à Diretoria de Ensino Regional, desmentindo o boato, ao mesmo tempo em que apresentava um projeto de reforma do espaço físico da escola. Os professores acalmaram-se, reunindo-se à sua volta para observar a planta da proposta de reforma, sobre a qual começaram a fazer perguntas e levantar questões. Surgem propostas de formação de "salas- ambiente" e desvia-se o assunto (dos conflitos e insatisfações anteriores, da precariedade do ensino noturno, do desrespeito aos professores em não serem ouvidos e tantas outras questões que causaram tanto desgaste aos profissionais durante aquela semana) para a discussão da viabilização da reforma do espaço físico. Achando por bem não interromper os professores, agendei novo horário com a coordenadora pedagógica, a fim de dar seguimento à pesquisa na reunião da semana seguinte.

É interessante notar a "efemeridade" com que as temáticas e problemas surgem, explodem e se diluem, sem que tenham sido resolvidas em sua essência. Provoca estranhamento a facilidade com que problemas graves são substituidos por outras questões de menor importância e resolutividade. Essa atitude coletiva, de deslocamento e remanejamento dos problemas - sem solucioná-los realmente - não parece ser uma atitude saudável. Mais do que isso, tal atitude talvez possa alimentar sentimentos de insatisfação crônica e até mesmo gerar as reações de aparente indiferença, insensibilidade, "anestesia" ou embrutecimento dos professores que provavelmente buscam, nesse aparente distanciamento, uma maneira de defenderem-se e resistirem à enorme carga psíquica negativa correspondente às maneiras como os problemas são trazidos e tratados naquele ambiente escolar. Afinal, para que se incomodar, e envolver-se, desgastar-se e sofrer se, brevemente, desvia-se o assunto e tudo permanece como estava?

No terceiro agendamento realizado, cheguei com 30 minutos de antecedência e isso possibilitou que o primeiro assunto da pauta da reunião fosse a pesquisa. Os professores participaram atentamente e houve uma recepção mais calorosa por parte de duas professoras que já me conheciam.. Ainda assim, houve muitos faltantes e foi necessário um quarto agendamento - dificultado devido ao choque de horários dos HTPCs das outras escolas previamente agendadas e pela impossibilidade de os professores comparecerem em outro horário. Assim, a coordenadora pedagógica se dispôs a ela mesma aplicar o questionário aos 
professores que faltavam. Esta foi orientada pela pesquisadora em como proceder e assim foi feito, finalizando desta forma o levantamento nessa escola.

No dia 4 de setembro, ocorreu um black-out durante 40 minutos no bairro onde se localiza a Escola 1 e, nessa ocasião, os alunos do período noturno que estavam em aula nessa escola começaram a depredar a escola, em ato de vandalismo, gritando e atirando cadeiras contra as vidraças das janelas da escola. $\mathrm{O}$ fato foi divulgado nos dias seguintes, nos jornais locais. Alguns poucos dias após, em 9 de setembro, um adolescente encapuzado adentrou a Escola 1 e matou a tiros um estudante. $O$ fato foi noticiado pela imprensa local e regional.

A questão da indisciplina e da violência nas escolas já foram apontadas por CARNEIRO (2001), que observou não haver um só dia sem ocorrências graves na Escola 1, chegando até mesmo às ocorrências policiais e criminais, conforme os fatos acima citados. Essa autora observou que os professores sentem medo dos alunos e que não os enfrentam, pois temem estar se confrontando com "bandidos". As observações realizadas durante a primeira fase dessa pesquisa corroboram esses dados indicativos de que a ocorrência explícita da violência nas escolas abala o estado emocional de professores e alunos, funcionando como agravante do complexo quadro de trabalho do professor, com conseqüências negativas para sua atuação profissional, vida pessoal e para sua saúde.

Os dados da observação da Escola 1 evidenciam uma realidade de trabalho muito distante daquela preconizada nas propostas de Escolas Promotoras de Saúde e também muito diferente da realidade encontrada em algumas escolas como, por exemplo, na pesquisa de SILVEIRA (2000), na qual a autora encontrou uma escola de boa qualidade, saudável, agradável e promotora de estilos de vida saudáveis; com características físicas e ambientais de beleza, cuidado e conservação do patrimônio e uma comunidade escolar que mantém um relacionamento cordial e respeitoso entre os profissionais, alunos e familiares e que demonstra preocupação com o bem estar de todos. 


\section{Escola 2}

Localizada na região central da cidade, a Escola 2 ocupa toda uma quadra. Recentemente recebeu pintura nova nas áreas externas, teve seus jardins externos e a pintura interna dos corredores restaurados segundo a original, da década de 50. A entrada encontra-se decorada com trabalhos realizados pelos alunos alusivos à Copa do Mundo de futebol. A coordenação pedagógica recebeu gentilmente a pesquisadora e agendou o encontro com os professores para uma data posterior, visando respeitar as tarefas e atividades com que eles estariam envolvidos durante as próximas duas semanas. Na data agendada, faltaram muitos professores pois estavam realizando um curso. Uma outra coordenadora se dispôs a entregar os questionários restantes para os professores faltantes, o que se tomou inviável devido ao recesso escolar. Ao final do mês de julho, houve mais um agendamento com os professores, fato esse que contou com a colaboração da vice-diretora em avisar e preparar os professores para a vinda da fonoaudióloga à escola. A vice-diretora mostrou-se muito atenciosa e colaboradora, apresentando-me aos professores, enquanto me acompanhava, disponibilizando-se para entregar o questionário àqueles professores que não poderiam estar presentes na reunião. Fizemos as duas reuniões com a pesquisadora se deram em sala ampla destinada para esse fim e que conta com uma mesa à frente, carteiras dispostas em fileiras, lousa, ventiladores, televisão com vídeo, amplos vitrôs e cortinas, bem conservados. As condições de limpeza do local se mostravam apropriadas. Todos os professores convidados concordaram em participar da pesquisa. Os professores mostraram-se alegres, participativos e interessados, vindo indagar e relatar fatos pertinentes ao tema. $\mathrm{O}$ ambiente sócio-interacional mostrou-se positivo entre os professores que, mesmo quando se tratava de comentar seus problemas e necessidades de saúde, valiam-se de ironia e ludicidade. Assim, sem intercorrências, foi concluído o levantamento de dados com os professores desta escola. 


\section{Escola 3}

A Escola 3 localiza-se em um bairro, a menos de um quilômetro da Escola 1 e numa avenida bastante movimentada, com muito ruído. Ocupa uma quadra e possui gramado externo e um pequeno jardim interno, simples, mas com grama bem aparada e verde, algumas folhagens e arbustos floridos. Os professores reúnem-se na sala dos professores, de frente para o gramado. É uma sala pequena, abafada, com poucos vitrôs e muito sol. Entretanto parece ser aconchegante, pois as mobílias encontram-se mais próximas formando diferentes ambientes. Logo à entrada, ao lado da porta os professores dispõem de galão de água e garrafa de café, com copos plásticos e de vidro, arnumados sobre uma bandeja com toalhinha.. Na parede, duas lousas com recados variados, agendamentos de atividades da escola, participação e apoio em eventos públicos, etc. Ao fundo da sala, três armários de ferro com portas individuais compõem um ambiente fechado, destinado aos pertences dos professores. Encostados em um destes armários, em formato de "U” há três sofás e uma mesa de centro com jornais, revistas variadas e catálogos de propaganda de produtos diversos. Muitos professores sentam-se nestes sofás e folheiam as revistas e catálogos, enquanto conversam. Há duas grandes mesas em formato de "L" com cadeiras, onde a maioria dos professores se acomoda durante a reunião. Nas duas visitas realizadas, presenciei a chegada de materiais enviados pelo Governo do Estado, como livros novos e de boa qualidade e "kits" com aparelhos de "walkman" para serem utilizados nas aulas de física. Os professores reuniram-se à volta das caixas para apreciar o material.

A diretora apresentou-me pessoalmente à coordenadora pedagógica, que me acompanhou nos dois encontros agendados, em reuniões de HTPC, fazendo a apresentação aos professores. Esses entravam alegres na sala, cumprimentavam-se e a mim também, em um ambiente cordial, descontraído e receptivo. Conversavam sobre assuntos variados e inclusive solicitavam ajuda mútua e sugestões para o que comprar de presente para o "Dia dos Namorados". Todos ouviram atentamente minhas explicações e a maioria participou prontamente da pesquisa. Alguns justificaram a impossibilidade por estarem saindo para a sala de aula e 3 sujeitos propuseram a levar os questionários para respondê-los em classe e a trazêlos pessoalmente, o que fizeram conforme combinado: Teceram comentários elogiando a iniciativa da temática da pesquisa, acharam interessante e experiência de responder aos questionários e a oportunidade de reflexão que estes favoreceram. Alguns, em especial, vieram 
falar de algumas questões especificas de saúde geral e vocal. Os professores conhecem as necessidades uns dos outros, e são unânimes em identificar determinados sujeitos com maiores necessidades vocais. $O$ processo de coleta de dados transcorreu tranqüilamente nessa escola; os professores reafirmaram o interesse em saber dos resultados da pesquisa e, dias após, ainda comentavam sobre o questionário, entre si.

\section{Escola 4}

A escola 4 localiza-se próxima à região central. A entrada conta com uma sala de espera com sofás e mesas laterais, além de uma mesa decorada com trabalhos realizados pelos alunos, alusivos à Copa do Mundo de futebol. Nas paredes, diversos quadros e cartazes com fotos de eventos, passeios e atividades artístico-culturais realizadas pelos alunos e professores, cujos nomes eram referidos nas mensagens abaixo das fotos. A sala onde os professores se reúnem é bastante pequena, com pouca ventilação. Logo à entrada, fica uma mesa redonda com 4 cadeiras e ao fundo da sala há uma mesa maior; várias cadeiras à volta da sala, encostadas nas paredes, e ali os professores se acomodam.. Ao fundo, uma pia, com vasos e plantas; lateralmente, uma lousa e painéis informativos com programação de atividades variadas, agendas de viagens, fotos, prestação de contas de festas beneficentes, e outras informações atualizadas.

O agendamento da reunião para a realização da pesquisa foi feito com a diretora, que se esqueceu de comunicar à coordenadora pedagógica e, no dia previsto, estavam apenas 5 professores, já que os demais se encontravam em um curso realizado naquele dia; em outro local. Os professores cumprimentavam-se, conversavam entre si e demonstraram-se participativos e colaborativos com a pesquisa, porém não teceram comentários a não ser sobre alguns problemas de saúde. A visita da pesquisadora fê-los relembrar, com carinho, da experiência com uma fonoaudióloga voluntária que realizara um acompanhamento processual de saúde vocal com um grupo de professores havia aproximadamente dois anos, naquela escola. Os professores valorizam a ação neste campo, pois puderam experienciar seus 
beneficios diretos numa proposta de trabalho processual; e alguns reclamam a necessidade de continuidade daquele trabalho, pois os problemas e dificuldades com a voz são recorrentes.

Em vista do número insuficiente de professores, foi agendado novo encontro no qual pôde ser concluída a primeira fase da pesquisa nessa escola.

Em geral, observa-se que todas as escolas vêm recebendo algum apoio do Governo Estadual em resposta a algumas de suas necessidades, o que pôde ser constatado em relação aos projetos e às obras de restauração, de reformas estruturais e ambientais ou meio de recebimento de materiais como recursos didáticos.

Entretanto, observam-se diferenças gritantes entre os quatro ambientes de trabalho visitados. Tais diferenças expressam-se tanto nas formas de expressão e manifestação dos alunos (como nos casos de violência registrados na Escola 1); como nas condições físicas e estruturais da escola e dos espaços reservados especialmente para o corpo docente; bem como nas formas como se dão as relações interpessoais e hierárquicas na escola (em todos os níveis) e o ambiente social, interativo, comunicativo, afetivo e emocional a elas inerente.

Dentre todas as escolas, a que chama a atenção pela precariedade nos aspectos mencionados é a Escola 1 e, especialmente, em se tratando das relações interpessoais e hierárquicas, esse campo da organização do trabalho encontra-se seriamente comprometido e carente de muitos investimentos - para os quais talvez a Psicologia e a Fonoaudiologia possam trazer grandes contribuições, no sentido da promoção da saúde na escola. 


\section{2 - ANÁLISE DESCRITIVA DAS QUESTÕES}

Tabela 1 mostra a descrição da amostra para Sexo, Idade e $\mathrm{N}^{\circ}{ }^{\text {de }}$ períodos em que o professor leciona.

Tabela 1. Análise descritiva dos dados dos professores, para Sexo, Idade e Número de periodos em que leciona.

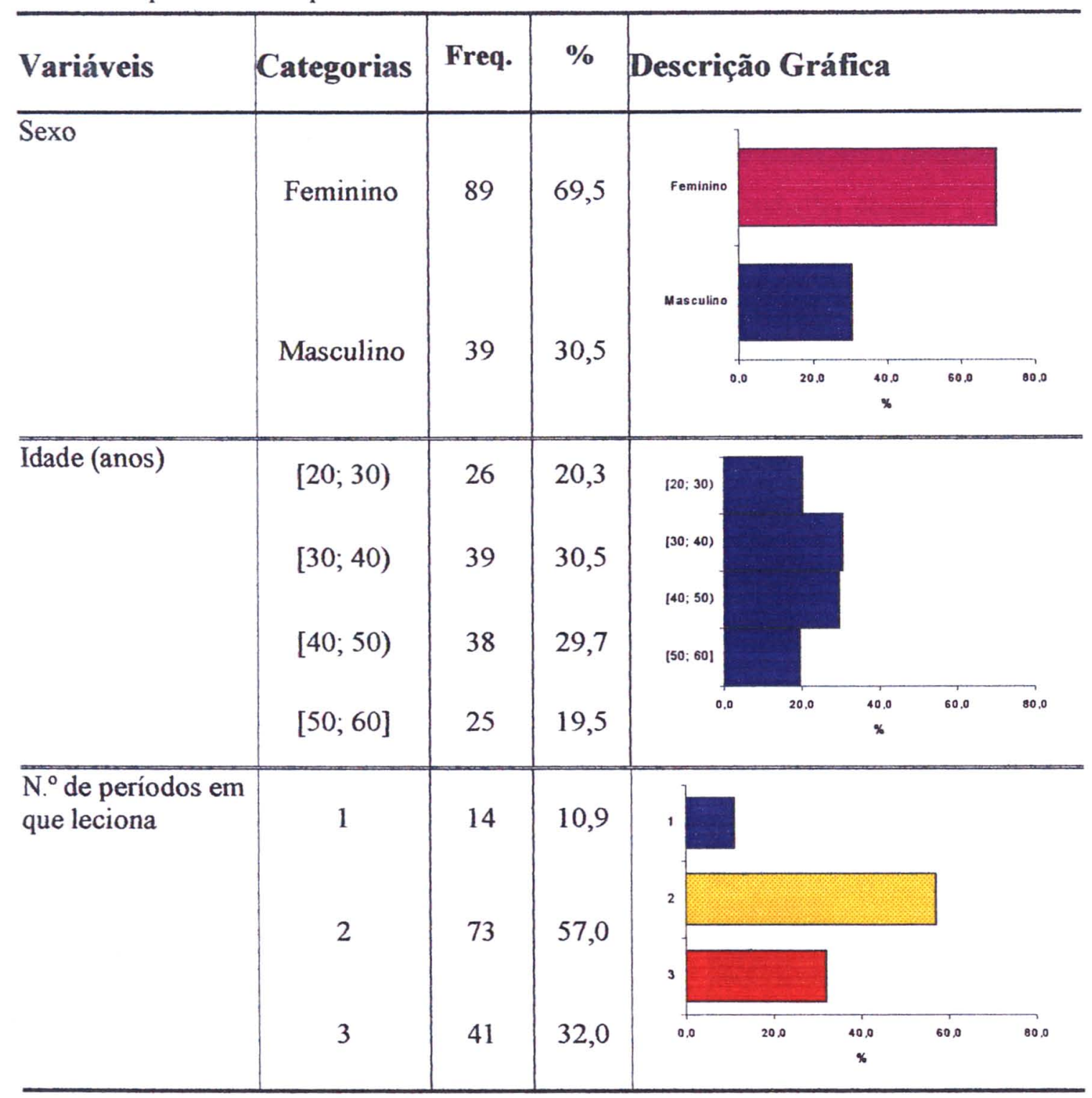


Observa-se que 69,5 \% dos sujeitos são do sexo feminino e 30,5\% do sexo masculino, o que demonstra a prevalência de mulheres trabalhadoras no Ensino Médio e a importância de se levar em conta as questões de gênero, abordadas no capítulo 1 desta pesquisa, nas ações dirigidas a docentes do Ensino Médio.

A idade variou de 20 a 60 anos, com média de 39,6 anos, e as classes mais freqüentes foram de 30 a 39 anos $(30,5 \%)$ e de 40 a 49 anos (29,7\%). A maioria dos professores (57\%) leciona em 2 períodos; e $32 \%$ deles lecionam em 3 períodos.

$\mathrm{O}$ fato de lecionar em dois ou mais períodos normalmente se relaciona com o trabalho em diferentes escolas, o que obriga a deslocamentos no município e até entre diferentes cidades, o que se reflete na redução dos intervalos para alimentação e descanso, conforme observara CARNEIRO (2001). A carga horária elevada de trabalho docente é apontada por autoras como PORDEUS, PALMEIRA e PINTO (1996) como um fator de risco ao desenvolvimento e à manutenção de alterações vocais. A docência em diversos períodos também pode interferir na qualidade da vida familiar e social do professor; além do que, conforme GRILLO (2001), ao professor que trabalha muitas horas por dia pouco tempo sobra para cuidar da própria saúde geral e vocal.

As Tabelas 2.a. e 2.b. referem-se aos dados gerais do QVV, à questão de como avalia a própria voz e aos dados do domínio global.

Tabela 2.a. Análise descritiva das respostas dos professores para a questão: Como você avalia sua voz?

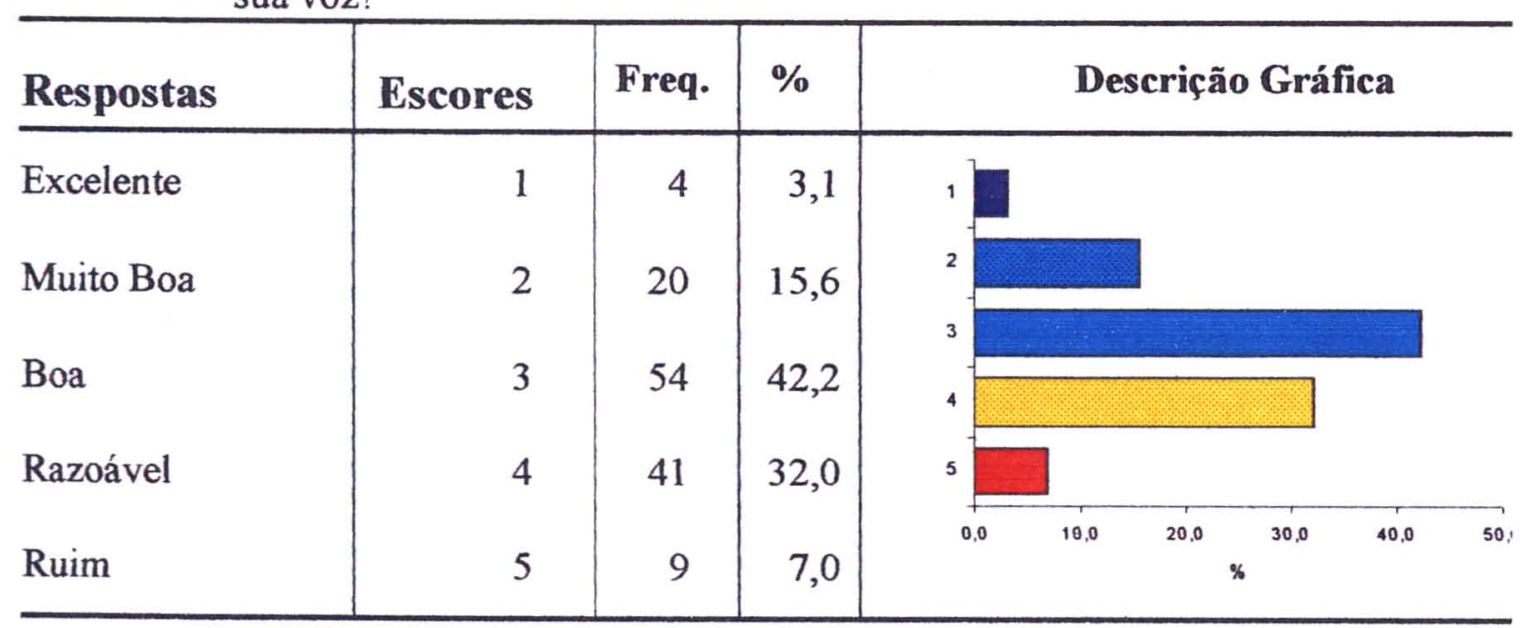


Tabela 2.b. Classes de freqüência do domínio global do questionário QVV.

\begin{tabular}{|c|c|c|c|c|c|c|c|}
\hline Classes & Freqüência & $\%$ & \multirow{6}{*}{$\begin{array}{c}0.20 \\
2194040 \\
41 \text { a } 60 \\
6198080 \\
81 \text { a } 100\end{array}$} & \multicolumn{4}{|c|}{ Descrição Gráfica } \\
\hline 0 a 20 & 1 & 0,78 & & & & & \\
\hline 21 a 40 & 5 & 3,91 & & & & & \\
\hline 41 a 60 & 11 & 8,59 & & & & & \\
\hline 61 a 80 & 38 & 29,69 & & & & & \\
\hline 81 a 100 & 73 & 57,03 & & & & & \\
\hline Total & 128 & 100,00 & & 0 & $40 \times{ }^{60}$ & 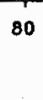 & \\
\hline
\end{tabular}

Na Tabela 2.a é mostrada a análise descritiva da questão na qual o professor avalia a sua própria voz. Verifica-se que $42,2 \%$ da amostra avaliaram sua voz como boa, enquanto $39 \%$ avaliaram como razoável ou ruim, e 18,7\% como muito boa ou excelente.

A Tabela 2.b. apresenta as classes de freqüência dos escores obtidos no domínio global da QVV. Observa-se que o impacto "ruim" da voz sobre a qualidade de vida de professores do ensino médio pode ser considerado baixo, pois somente $13,28 \%$ dos sujeitos obtiveram escores no QVV entre 0 e 60 - lembrando que o impacto é pior e mais incisivo quanto mais próximos de zero estão os escores. Por volta de $29 \%$ dos sujeitos obtiveram os escores no intervalo entre 61 e 80, o que permite considerar que o impacto negativo da voz sobre a qualidade de vida seja "moderado", pois os escores se encontram acima de 50. Já $57,03 \%$ dos professores obtiveram zscores acima de 80 no QVV - o que é muito bom numa escala que varia de zero a 100 - e que jermite considerar estar sendo discreto o impacto da voz sobre a qualidade de vida desses iujeitos. Em outras palavras, na percepção da maioria dos professores envolvidos nessa pesquisa, i sua voz nunca ou raramente exerce impacto negativo sobre a sua qualidade de vida; a voz/saúde rocal não é considerada um problema em suas atividades de vida diária.

No momento da entrega dos questionários, conferi o preenchimento de todos os campos e ecia alguns comentários com os professores. Nessas ocasiões, foi possível observar que aqueles ujeitos que avaliavam suas vozes como razoáveis ou ruins possuíam vozes alteradas ou 
disfỏnicas (incluíam-se, nesse grupo, os sujeitos que haviam tído encaminnamento ou que haviam ${ }^{\text {se }}$ submetido a tratamentos fonoaudiológicos). Esses sujeitos tendiam a apresentar suas respostas do QVV como 4 e 5, ou seja, suas vozes produziam muito impacto sobre sua qualidade de vida, sendo, quase sempre ou sempre, considerado um problema ruim.

Assim, considerando a possibilidade de que os $39 \%$ dos professores que avaliaram suas vozes como razoável ou ruim, possam, realmente, apresentar alterações vocais ou problemas de saúde vocal, os resultados estariam compatíveis com os dados encontrados na literatura, quando trata de auto-avaliação dos sujeitos, pois estudos apontam $40 \%$ de professores que se percebem disfônicos (BETANCOURT e PALACIOS, 1999 e SIMÕES, 2001). No entanto, SIMÕES (2001), ao realizar a avaliação fonoaudiológicas naqueles professores constatou que, na verdade, $79 \%$ dos sujeitos apresentava disfonia.

Isso sugere o que outros autores já apontaram: que os professores são mais complacentes e generosos na auto-avaliação vocal; têm muita tolerância para usar a voz disfônica e passam a considerar a rouquidão e a voz alterada como voz "normal", habitual e "natural" no contexto da docência (OLIVEIRA, 1999 e DRAGONE e col. 1999). Autoras como VAZ et al. (1999 e 2002) também observaram a presença de uma auto-imagem vocal positiva em professores, discordante dos dados que indicavam queixas vocais, e grande prevalência de sintomas vocais negativos no mesmo grupo de professores.Há, portanto, uma contradição entre o número de queixas vocais e a baixa percepção vocal dos professores, o que levou as autoras a concluírem que os professores não se mostram suficientemente sensibilizados em relação às próprias queixas apresentadas, a ponto de mobilizarem-se para buscar ajuda profissional.

Cabe, ainda, considerar que a categoria docente apresenta grande resistência para buscar atendimento especializado na área de voz (OLIVEIRA, 1999) e, nesse contexto, é possível que a resistência se manifeste, também, na dificuldade em valorizar e perceber os sintomas vocais, a ponto de assumir uma avaliação da própria voz como alterada - aqui razoável ou ruim. Há, portanto, uma distância entre a auto-avaliação vocal de professores e a avaliação fonoaudiológica (DRAGONE, 1996; NAGANO e BEHLAU, 2000), pois, enquanto para o fonoaudiólogo a voz seria "ruim", classificada no campo da disfonia, para o professor ela é "razoável". Fica, 
entretanto, uma pergunta: quantos professores teriam avaî́aao suas vozes como voas, mexz: tendo queixas e alterações vocais?

Note-se que $39 \%$ percebem suas vozes como razoáveis ou ruins; entretanto apenas $13,28 \%$ dos professores avaliaram o impacto da voz/saúde vocal sobre a sua vida diária como ruim (escores abaixo de 60; dentre os quais apenas 4,68\% abaixo de 40). Isso significa que mesmo entre os sujeitos com vozes razoáveis ou ruins (possivelmente disfônicos), poucos são aqueles que consideram o impacto negativo da voz sobre o cotidiano e que consideram isso um problema na vida diária e na qualidade de vida.

Haveria uma restrição nå capacidade de auto-avaliação vocal e de percepção da disfonia e do impacto da voz/saúde vocal na vida diária?

Nesse sentido, diversos autores já apontaram a desinformação, a resistência e o desinteresse do professores e graduandos em Pedagogia a respeito dos assuntos sobre voz e uso profissional da voz (CARELLI, 2002). Se realmente ocorre tal restrição na percepção de professores acerca da sua voz, cabe aqui uma reflexão sobre ser essa realmente uma questão de "informação". Ou seria uma questão de percepção da voz, enquanto componente da integridade, subjetividade e expressividade do sujeito; como resultante de um construto decorrente de vivências de ordem pessoal, social, formativa, cultural e histórica? Nesse caso, a percepção difere segundo as experiências individuais e coletivas dos sujeitos e grupos profissionais aos quais pertencem. E, assim, as diferenças encontradas nas formas de pensar, interpretar, significar, considerar e avaliar a voz como saúde vocal, entre fonoaudiólogos e professores, é perfeitamente natural, compreensível e esperado. Afinal, a voz e a saúde vocal são um dos objetos de trabalho dos fonoaudiólogos, e não do professor de Ensino Médio.

Talvez caiba à Fonoaudiologia assumir as diferenças de percepção da voz enquanto especificidades inerentes a cada campo de atuação, sem a pretensão de anulá-las e sem a "arrogância" de esperar das demais categorias profissionais a mesma percepção sobre a saúde vocal que os profissionais dessa área possuem (ou melhor, "construiram" durante seu processo formativo na graduação e na pós-graduação strictu e latto senso - em pesquisas na área de voz). Na verdade, trata-se de uma questão que envolve mais a valoração e a significação da voz e da saúde vocal do sujeito em seu cotidiano e em seu grupo social do que propriamente a informação sobre o problema 
Nessa perspectiva, também vale lembrar DRAGONE (2000), que considera o distanciamento entre a valoração e importância atribuída à voz como um dos aspectos responsáveis pelo desinteresse e pela apatia dos professores em relação à sua voz. Segundo essa autora, na valoração atribuída pelos fonoaudiólogos, o enfoque direciona-se para os problemas de voz e a sua prevenção; na valoração atribuída pelos professores/pesquisadores da educação, o enfoque recai sobre atitudes, comportamentos e recursos didáticos do docente. DRAGONE (2000) sugere que a interface entre essas especialidades possa ocorrer na consideração da voz como componente dos recursos didáticos e da interação professor-aluno.

Somente quando se assume o caráter sócio-histórico-cultural da voz como linguagem, torna-se possível, para a Fonoaudiologia, aceitar com humflldade, as diferenças na valoração e nas significações atribuídas à voz, como inerentes a cada grupo social ou profissional de convívio e de pertença dos sujeitos, levando-se em conta, ainda, as subjetividades. Nessa perspectiva, para a Fonoaudiologia, não se trata simplesmente de deixar de focalizar as alterações vocais para focalizar o recurso didático ou de interação; é preciso ampliar e avançar a reflexão para a(s) concepção(ões) de voz/linguagem/sujeito em que se pauta; é preciso desenvolver pesquisas que possibilitem conhecer as representações que a voz assume nos diferentes segmentos da sociedade e nas diferentes comunidades/realidades sócio-culturais, bem como os processos pelos quais são construidas tais representações. Reporto-me a LANE (1999) e GUARESCHI e JOVCHELOVITCH (2000) para destacar que vidas humanas e seus fenômenos psicossociais tomam forma e se constroem em relação a uma realidade social e histórica definida, num movimento dialético entre sujeito e sociedade.

Talvez aqui se encontre um aspecto que aponte para uma mudança de paradigmas nas ações de saúde vocal do professor, tradicionalmente pautadas pela transmissão da informação e por práticas normatizadoras dos hábitos e comportamentos vocais. Conforme PENTEADO (2003; p.338):

"há que se buscar avançar das normatizações e informações isoladas para a construção de processos educativos em saude vocal que levem em conta a subjetividade e a relatividade implícita às questôes sociais, familiares, econômicas/produtivas, laborais, ambientais, culturais das pessoas e que favoreçam a reflexão sobre o seu processo saúde/doença vocal no contexto das suas vidas, orientados pela problematização e transformação da realidade". 
Tal mudança de paradigma implica uma transformação das concepções, das ações e propostas de intervenção fonoaudiológica na promoção da saúde vocal, que passariam a incluir vivências que possibilitem ao fonoaudiólogo conhecer as representações que os sujeitos construíram de sua voz no decorrer de sua vida e em determinados grupos sociais. Dessa forma poderiamoferecer oportunidades para o sujeito ter maior "contato" com sua própria voz; para experienciar e vivenciar, nas relações sociais, o impacto da voz sobre as pessoas, sobre as interações cotidianas e sobre o trabalho - o que repercute sobre o sujeito, sobre sua auto-estima pessoal e projeto/desempenho profissional; bem como oportunidades para sentir, refletir e transformar a voz em sua aplicabilidade cotidiana e em sua dimensão da subjetividade humana.

A Tabela 3 apresenta a análise descritiva das questões específicas do QVV, com as respostas (categorias) e respectivos escores. 
Tabela 3. Análise descritiva das respostas, escores, freqüências e porcentagens referentes à Qualidade de Vida relacionada à Voz, resultados obtidos por meio do questionário QVV.

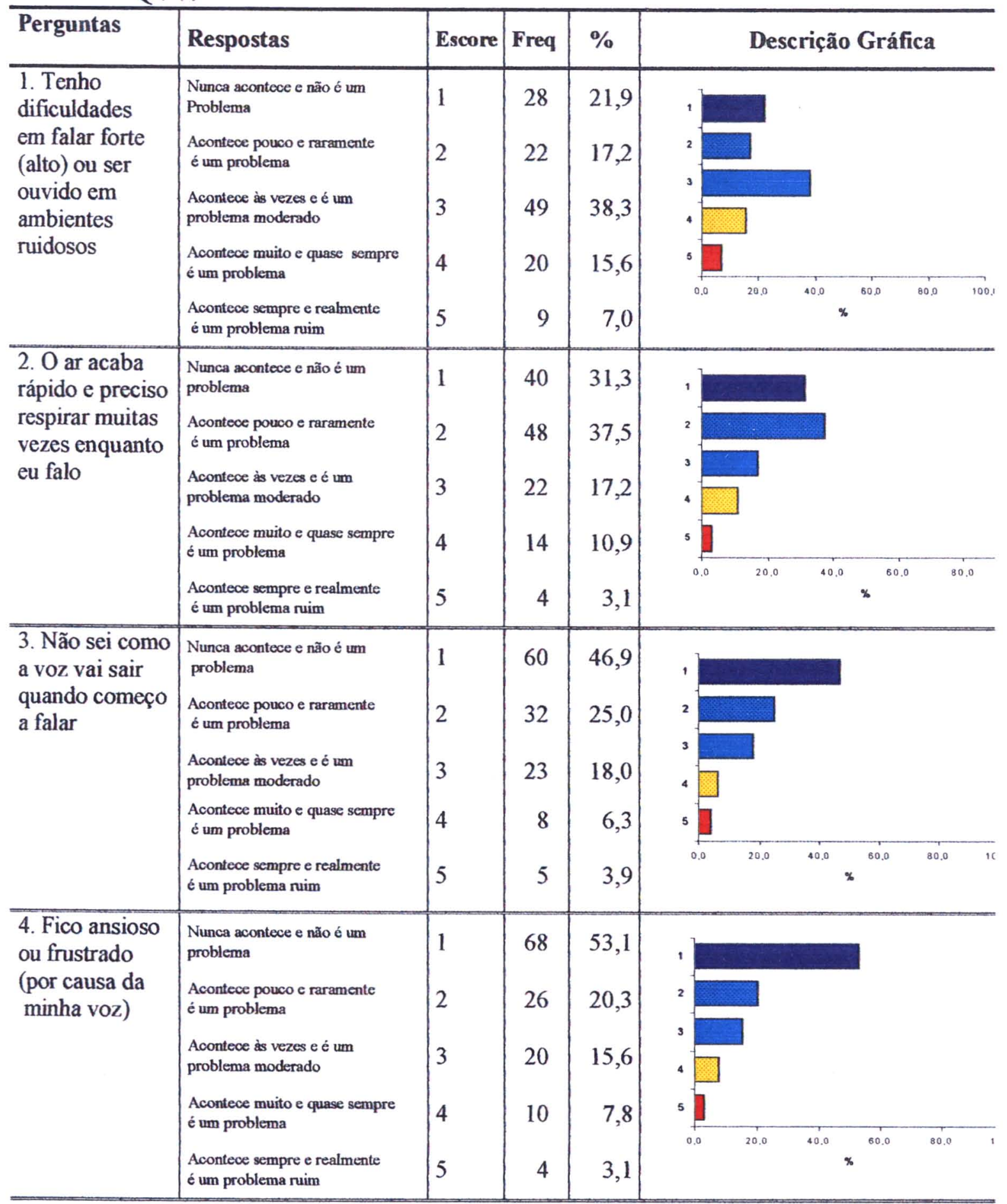


Tabela 3. Continuação

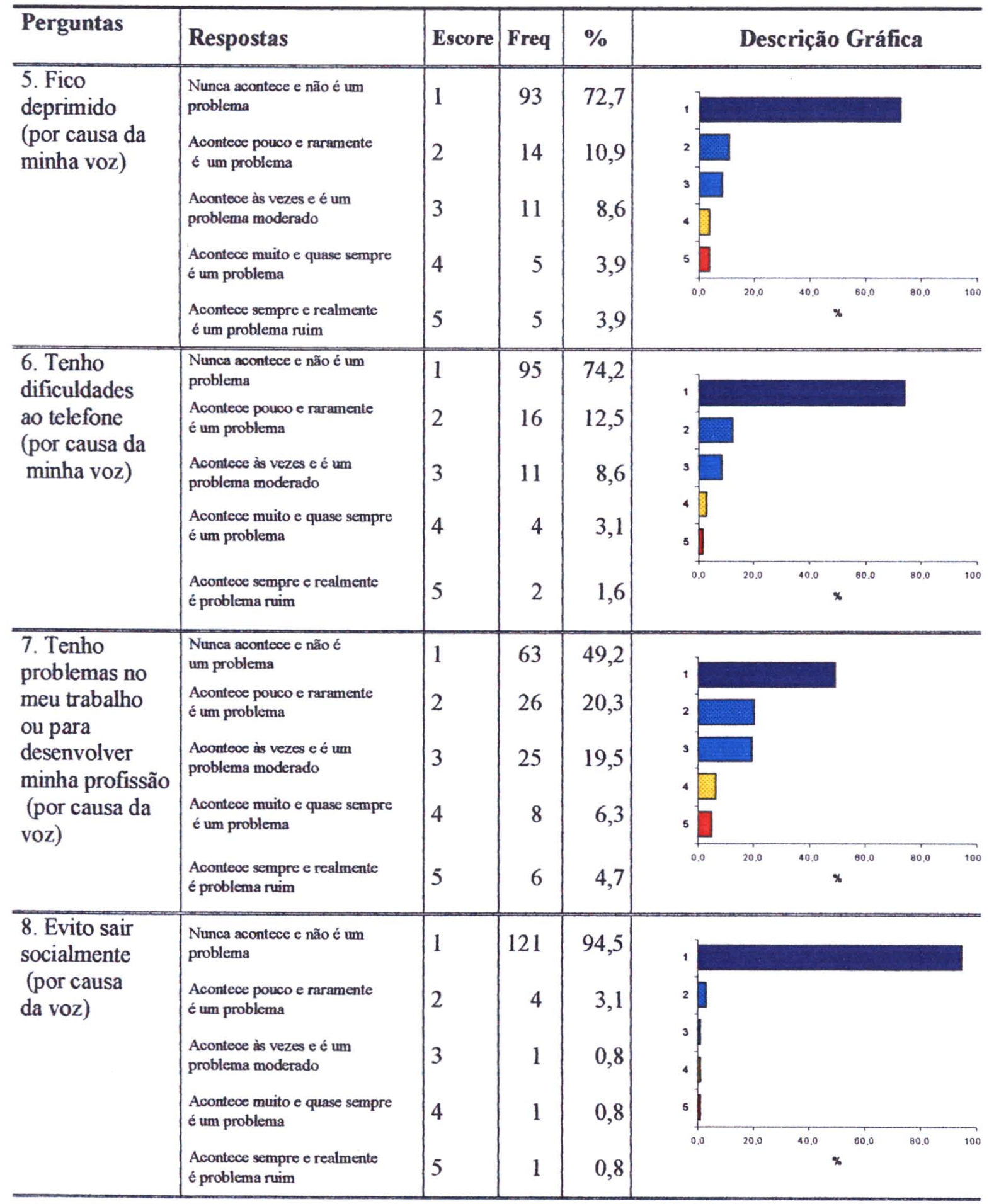


Tabela 3. Continuação

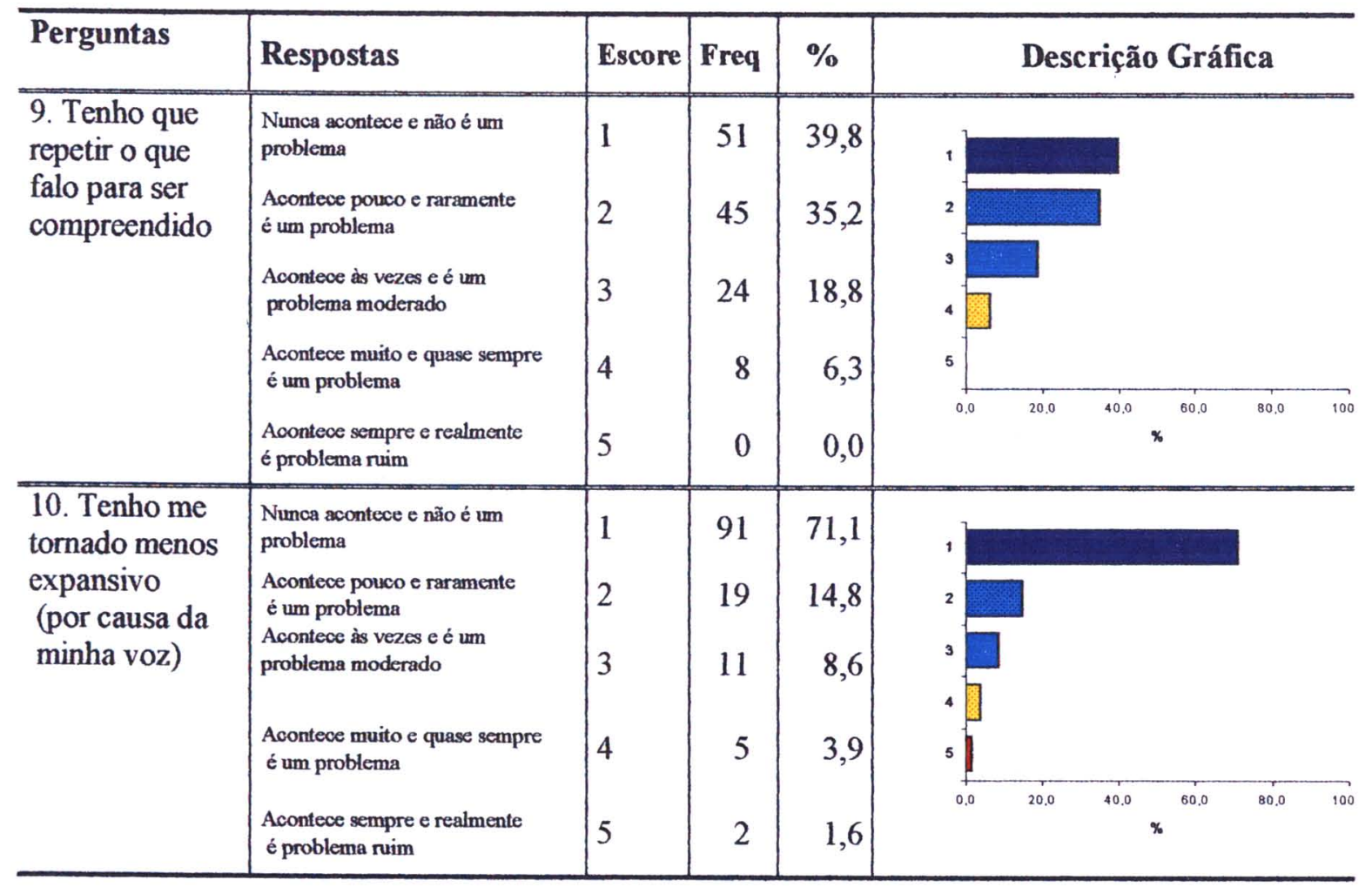

Nota-se que $60,9 \%$ dos sujeitos afirmaram que por causa da voz têm dificuldades em falar forte (alto) ou ser ouvidos em ambientes ruidosos (Questão 1), sendo que para a maioria, 38,3\% dos sujeitos, isso é um problema moderado, ao passo que para $22,6 \%$ é um problema ou problema ruim. Dentre todos os aspectos/questões pontuados pelo QVV, essa questão foi à qual os professores mais atribuíram o status de problemática ocorrida.

A dificuldade em falar forte em ambientes ruidosos é um aspecto bastante relevante, quando se trata da saúde vocal do professor; entretanto, quando o professor compensa as suas dificuldades de falar forte e de ser ouvido, simplesmente elevando o volume de voz, estaria provocando constante abuso vocal com sobrecarga funcional do aparelho fonador (OLIVEIRA, 1999). A atividade docente em ensino médio requer resistência vocal, para o uso da voz em forte intensidade e com boa projeção vocal, enquanto necessidades de saúde vocal e recursos didáticos e de organização e disciplina em sala de aula, inerentes à atividade docente. $\mathrm{O}$ uso da voz em forte intensidade implica seu preparo adequado para o desenvolvimento do apoio respiratório 


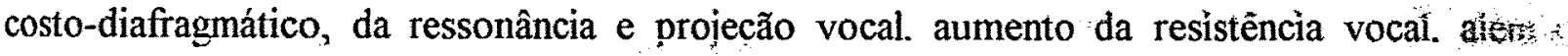
adequado aquecimento e desaquecimento vocal, pré e pós o uso profissional da voz nas aulas.

A ocorrência de $60,9 \%$ de professores com dificuldades com o uso intenso da voz exprime, aqui, o investimento na resistência vocal (bem como em ajudar o professor a explorar e desenvolver sua intensidade vocal), como um aspecto positivo e uma das necessidades de desenvolvimento da saúde vocal a serem trabalhados nas ações direcionadas ao professor de Ensino Médio. A intensidade vocal seria, portanto, abordada numa perspectiva positiva, de aprimoramento e desenvolvimento, ao invés da maneira como vem sendo abordada na maioria das normas e regras de "higiene vocal", ou seja, como um aspecto genericamente negado, considerado inadequado ou fator de risco vocal, que afirma a perspectiva negativa do uso da voz com maior intensidade.

Na segunda questão, mostrada na Tabela 3, para a maioria dos professores não acontece ou acontece poucas vezes de o ar acabar rápido e precisar respirar muitas vezes enquanto fala. A incoordenação pneumofonoarticulatória normalmente está relacionada ao mau uso vocal e utilização de técnica vocal inadequada; entretanto isso parece não ser um aspecto relevante nesse grupo, uma vez que um contingente menor de sujeitos (por volta de $31 \%$ ) indicou a freqüência e grau de problemática como moderado ou ruim.

Em relação à terceira questão, para 46,9\% dos sujeitos não é um problema como sairá sua voz quando começa a falar; $28,2 \%$ assinalaram os escores entre 3 e 5 , indicativos da freqüencia de ocorrência do problema, considerado de moderado a ruim. Essa questão relaciona-se à instabilidade e variabilidade da fonação e da qualidade vocal; e o fato de esses $46,9 \%$ dos professores não terem dúvidas de como sairá sua voz ao falar não atesta a sua saúde vocal, pois ainda há a possibilidade de que dentre estes mesmos sujeitos haja vozes alteradas, com qualidade vocal rouca porém estável. De qualquer maneira, apreende-se, aqui, que a instabilidade e variabilidade da qualidade vocal raramente são consideradas problemas pelos professores.

A maioria dos indivíduos assinalou o escore 1 para a questão 4 - sentir-se ansioso ou frustrado $(53,1 \%)$; questão 5 - sentir-se deprimido $(72,7 \%)$; questão 6 - ter dificuldades ao falar ao telefone $(74,2 \%)$; questão 8 - evitar sair $(94,5 \%)$ e questão 10 - tornar-se menos expansivo 
$(71,1 \%)$. Tais respostas indicavam que os aspectos em questão nunca acontecem e não são problemas. Esses dados demonstram que professores não se deprimem, não deixam de participar de suas atividades sociais nem alteram seu comportamento social em função da sua voz.

Surgem aqui algumas questões:

- As mudanças na voz teriam baixo impacto sócio/emocional no professor ou simplesmente haveria algum impacto pouco identificado?

- Os professores estariam atribuindo pouca atenção ao impacto da voz nos seus relacionamentos sociais e até mesmo sobre as suas emoções/sentimentos?

Nesse caso, esses seriam dois aspectos a serem incluidos e trabalhados nas ações de saúde vocal do professor.

Apenas $11 \%$ assinalou os escores 4 ou 5 na questão 7 ; e a grande maioria assinalou o escore 1 , indicando que, para $49,2 \%$ dos sujeitos, nunca acontece de ter problemas no trabalho ou para desenvolver a profissão por causa da voz. Os dados dessa questão remontam novamente aos dados da questão 1 , indicativos de que a maioria enfrentava problemas para falar forte em ambientes ruidosos, em freqüência e graus variados; e, como foi visto, o exercício da docência envolve enfrentar classes numerosas e ruidosas, bem como a competição sonora com o som das vozes dos alunos, ruídos ambientais da sala de aula e ambiente externo - o que demanda o uso da voz em forte intensidade e resistência vocal. Ora, se os professores sentem dificuldades em falar forte e serem ouvidos em ambientes ruidosos, há que se esperar que isso implique em alguns problemas no exercício da profissão - o que não foi indicado nas respostas das questões 7 e 9 .

Na questão 9 , a maioria, $75 \%$ dos sujeitos, assinalou os escores 1 ou 2 , indicando que aunca acontece ou acontece pouco, e raramente é problema, o fato de ter que repetir o que fala para ser compreendido. Igualmente aqui há uma discordância entre as respostas das questões $1 \mathrm{e}$ 9: frente ao fato de ter dificuldade para falar forte e ser ouvido em ambientes ruidosos, seria de se esperar que, numa sala de aula lotada e ruidosa, o professor acabasse por se deparar com a necessidade de repetir várias vezes para ser ouvido/compreendido - o que não ocorre nas respostas. Seria, aqui, um indicativo das dificuldades e resistências do professor, em perceber e 
em assumir o impacto da sua voz sobre a sua vida cotidiana, em especial nos contextos de trabalho?

Considerando que o escore maior ou igual a 3 representa algum problema para os professores, pode-se evidenciar que a questão mais comprometida é a questão 1 (60,9\% assinalaram escores maiores ou iguais a 3, sugestivo de problemas em relação à acústica ambiental, nível de ruído ambiental e competição sonora); seguida pelas questões 2 (31,2\% assinalaram escores maiores ou iguais a 3, sugestivo de problemas em relação à demanda vocal intensa e incoordenação pneumofonoarticulatória); questão 7 (30,5\% assinalaram escores maiores ou iguais a 3, sugestivo de problemas no uso profissional da voz com implicações negativas sobre o trabalho); questão $3(28,2 \%$ assinalaram escores maiores ou iguais a 3 , sugestivo de problemas na qualidade vocal); questões 4 (26,5\% assinalaram escores maiores ou iguais a 3, sugestivo de sentimentos negativos decorrentes da auto-imagem vocal e das condições de uso da voz); 9 (25,1\% assinalaram escores maiores ou iguais a 3 , sugestivo de ineficiência na comunicação).

As respostas das questões 5, 6 e 10 sugerem que a voz/saúde vocal tem um baixo impacto negativo nas esferas social e emocional de professores (ou um impacto pouco percebido e/ou subestimado): na questão 5, 16,4\% assinalaram escores maiores ou iguais a 3 ); na $10,14,1 \%$ assinalaram escores maiores ou iguais a 3 ; e na ) e na 6, 13,3\% assinalaram escores maiores ou iguais a 3. Nesse sentido, a segunda fase dessa pesquisa poderá trazer contribuições para melhor compreensão desses dados. A questão menos comprometida é a questão $8(2,4 \%$ assinalaram escores maiores ou iguais a 3), sugestivo de que a voz/saúde vocal não provoca impacto negativo algum sobre a vida social dos professores - o que pode ser questionado. Daí a necessidade de aprofundar a investigação desse aspecto na segunda fase dessa pesquisa. 
$\mathrm{Na}$ Tabela 4, é apresentada a análise descritiva das respostas dos professores ao questionário WHOQOL/Breve, referentes à avaliação da Qualidade de Vida (QV), incluindo os respectivos escores, freqüências e porcentagens.

Tabela 4. Análise descritiva das respostas, escores, freqüências e porcentagens referentes à Qualidade de Vida (QV) dos professores, resultados obtidos por meio do questionário WHOQOL/Breve.

\begin{tabular}{|c|c|c|c|c|c|}
\hline Perguntas & Respostas & Escores & Freq & $\%$ & Descrição Gráfica \\
\hline $\begin{array}{l}\text { 1. Como você } \\
\text { avaliaria sua } \\
\text { qualidade de } \\
\text { vida? }\end{array}$ & $\begin{array}{c}\text { Muito ruim } \\
\text { Ruim } \\
\text { Nem ruim, nem boa } \\
\text { Boa } \\
\text { Muito boa }\end{array}$ & $\begin{array}{l}1 \\
2 \\
3 \\
4 \\
5\end{array}$ & $\begin{array}{r}1 \\
5 \\
31 \\
84 \\
7\end{array}$ & $\begin{array}{r}0,8 \\
3,9 \\
24,2 \\
65,6 \\
5,5\end{array}$ & 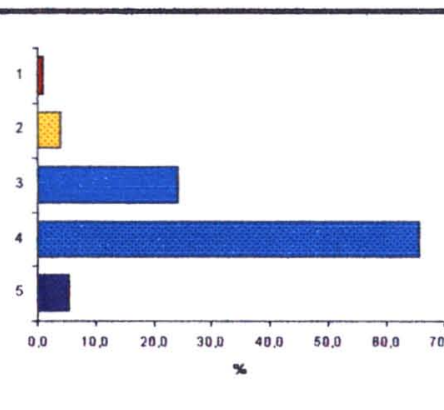 \\
\hline $\begin{array}{l}\text { 2. Quão } \\
\text { satisfeito(a) } \\
\text { você está } \\
\text { com a sua } \\
\text { saúde? }\end{array}$ & $\begin{array}{l}\text { Muito insatisfeito } \\
\text { Insatisfeito } \\
\text { Nem satisfeito, nem } \\
\text { insatisfeito } \\
\text { Satisfeito } \\
\text { Muito satisfeito }\end{array}$ & $\begin{array}{l}1 \\
2 \\
3 \\
4\end{array}$ & $\begin{array}{r}2 \\
17 \\
21 \\
77 \\
11\end{array}$ & $\begin{array}{r}1,6 \\
13,3 \\
16,4 \\
60,2 \\
8,6\end{array}$ & 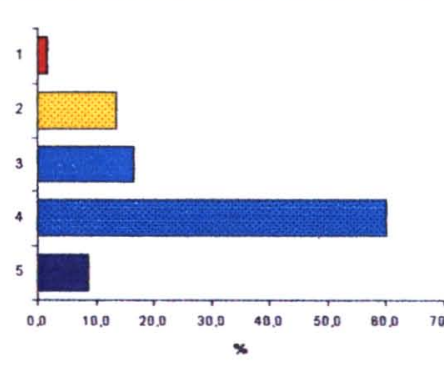 \\
\hline $\begin{array}{l}\text { 3. Em que } \\
\text { medida você } \\
\text { acha que sua dor } \\
\text { (fisica) impede } \\
\text { você de fazer o } \\
\text { que precisa? }\end{array}$ & $\begin{array}{c}\text { Nada } \\
\text { Muito pouco } \\
\text { Mais ou menos } \\
\text { Bastante } \\
\text { Extremamente }\end{array}$ & $\begin{array}{l}1 \\
2 \\
3 \\
4\end{array}$ & $\begin{array}{r}50 \\
33 \\
29 \\
14 \\
2\end{array}$ & $\begin{array}{r}39,1 \\
25,8 \\
22,7 \\
10,9 \\
1,6\end{array}$ & 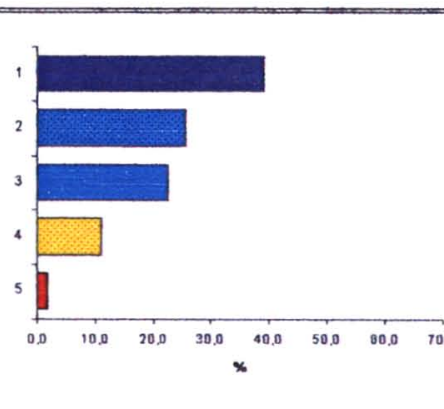 \\
\hline
\end{tabular}


Tabela 4. Continuação

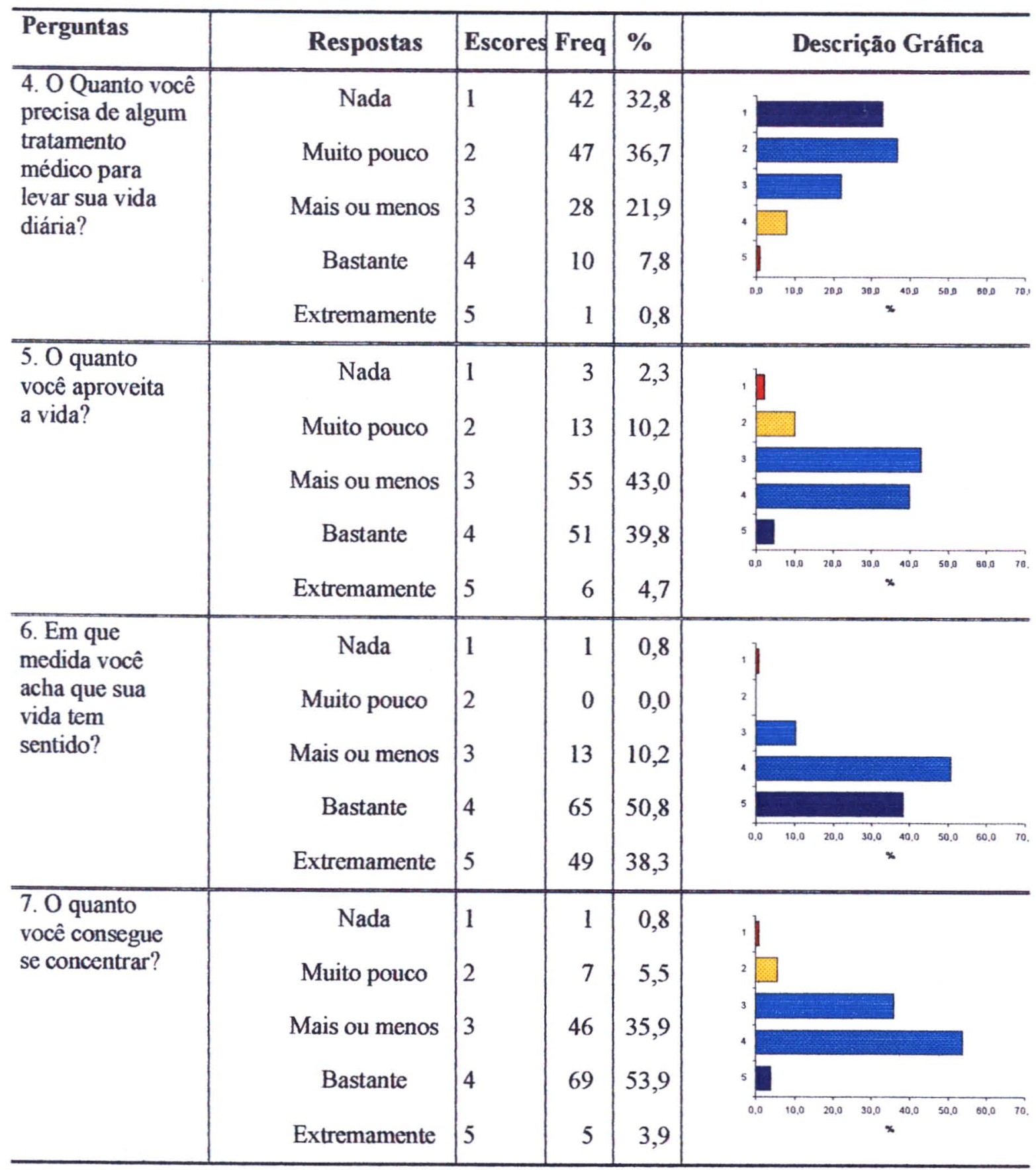


Tabela 4. Continuação

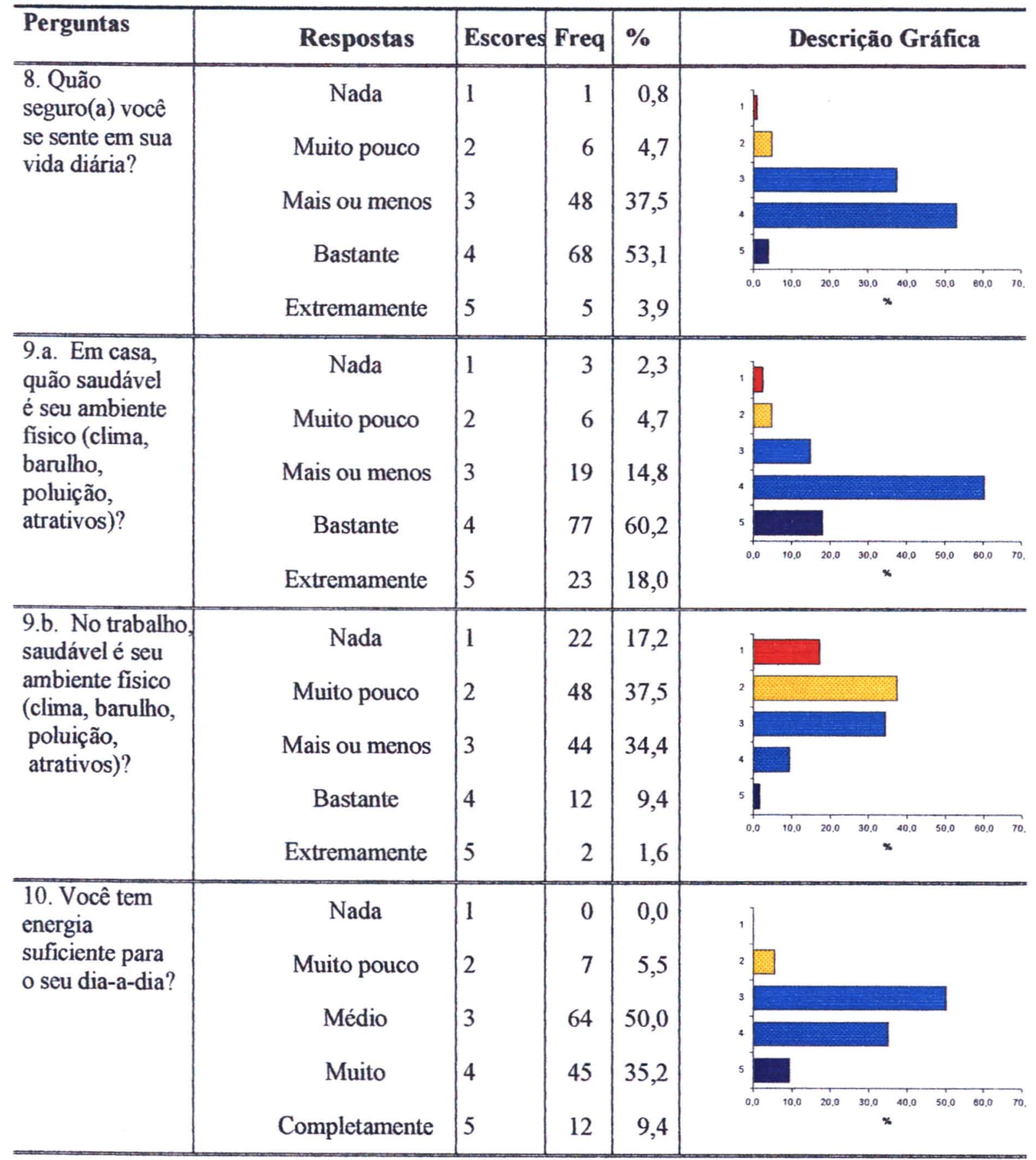


Tabela 4. Continuação

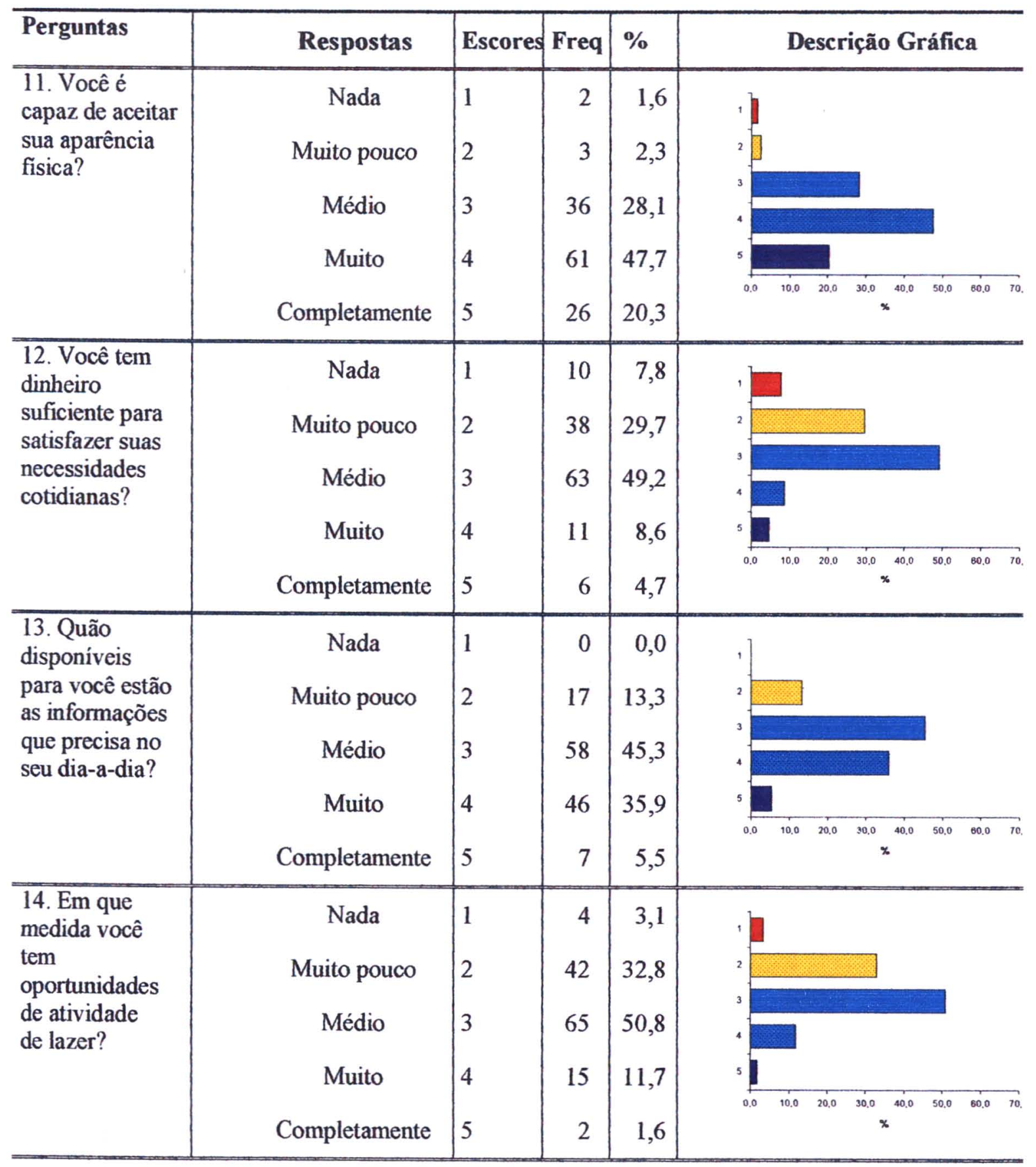


Tabela 4. Continuação

\begin{tabular}{|c|c|c|c|c|c|}
\hline Perguntas & Respostas & Escores & Freq & $\%$ & Descrição Gráfica \\
\hline $\begin{array}{l}\text { 15. Quão bem } \\
\text { você é capaz de } \\
\text { se locomover? }\end{array}$ & $\begin{array}{c}\text { Muito ruim } \\
\text { Ruim } \\
\text { Nem ruim, nem bom } \\
\text { Bom } \\
\text { Muito bom }\end{array}$ & $\begin{array}{l}1 \\
2 \\
3 \\
4 \\
5\end{array}$ & $\begin{array}{r}1 \\
3 \\
17 \\
51 \\
56\end{array}$ & $\begin{array}{r}0,8 \\
2,3 \\
13,3 \\
39,8 \\
43,8\end{array}$ & 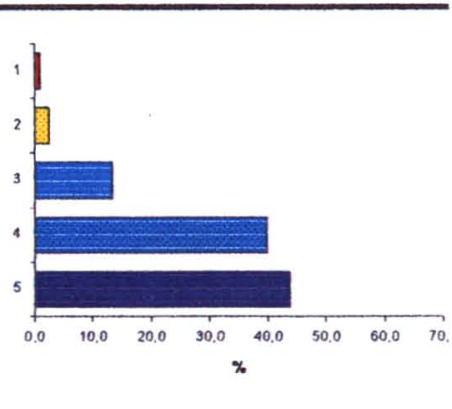 \\
\hline $\begin{array}{l}\text { 16. Quão } \\
\text { satisfeito(a) } \\
\text { você está com } \\
\text { o seu sono? }\end{array}$ & $\begin{array}{c}\text { Muito insatisfeito } \\
\text { Insatisfeito } \\
\text { Nem satisfeito, nem } \\
\text { insatisfeito } \\
\text { Satisfeito } \\
\text { Muito satisfeito }\end{array}$ & $\begin{array}{l}1 \\
2 \\
3 \\
4 \\
5\end{array}$ & $\begin{array}{r}5 \\
23 \\
23 \\
54 \\
23\end{array}$ & $\begin{array}{r}3,9 \\
18,0 \\
18,0 \\
42,2 \\
18,0\end{array}$ & 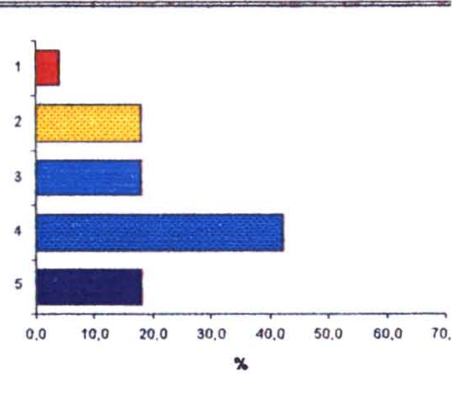 \\
\hline $\begin{array}{l}\text { 17. Quão } \\
\text { satisfeito(a) } \\
\text { você está com } \\
\text { sua capacidade } \\
\text { de desempenhar } \\
\text { as atividades do } \\
\text { seu dia-a-dia? }\end{array}$ & $\begin{array}{c}\text { Muito insatisfeito } \\
\text { Insatisfeito } \\
\text { Nem satisfeito, nem } \\
\text { insatisfeito } \\
\text { Satisfeito } \\
\text { Muito satisfeito }\end{array}$ & $\begin{array}{l}1 \\
2 \\
3 \\
4 \\
5\end{array}$ & $\begin{array}{l}3 \\
11 \\
43 \\
59 \\
12\end{array}$ & $\begin{array}{r}2,3 \\
8,6 \\
33,6 \\
46,1 \\
9,4\end{array}$ & 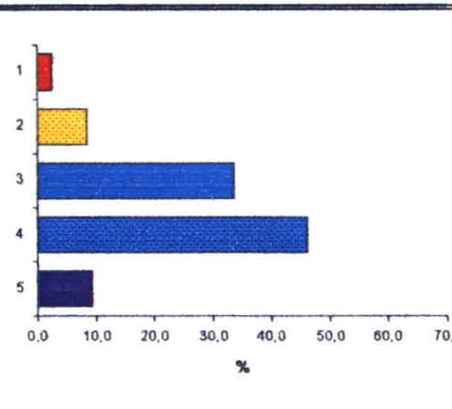 \\
\hline $\begin{array}{l}\text { 18. Quão } \\
\text { satisfeito(a) } \\
\text { você está com } \\
\text { sua capacidade } \\
\text { para o trabalho? }\end{array}$ & $\begin{array}{c}\text { Muito insatisfeito } \\
\text { Insatisfeito } \\
\text { Nem satisfeito, nem } \\
\text { insatisfeito } \\
\text { Satisfeito } \\
\text { Muito satisfeito }\end{array}$ & $\begin{array}{l}1 \\
2 \\
3 \\
4 \\
5\end{array}$ & $\begin{array}{l}3 \\
12 \\
29 \\
72 \\
12\end{array}$ & $\begin{array}{r}2,3 \\
9,4 \\
22,7 \\
56,3 \\
9,4\end{array}$ & 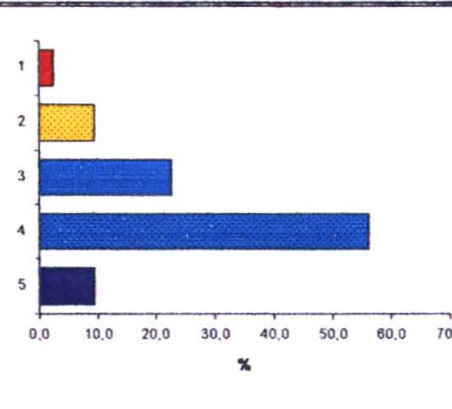 \\
\hline
\end{tabular}


Tabela 4. Continuação

\begin{tabular}{|c|c|c|c|c|c|}
\hline Perguntas & Respostas & Escores & Freq & $\%$ & Descrição Gráfica \\
\hline $\begin{array}{l}\text { 19. Quão } \\
\text { satisfeito(a) } \\
\text { você está } \\
\text { consigo } \\
\text { mesmo? }\end{array}$ & $\begin{array}{c}\text { Muito insatisfeito } \\
\text { Insatisfeito } \\
\text { Nem satisfeito, nem } \\
\text { insatisfeito } \\
\text { Satisfeito } \\
\text { Muito satisfeito }\end{array}$ & $\begin{array}{l}1 \\
2 \\
3 \\
4 \\
5\end{array}$ & $\begin{array}{r}1 \\
8 \\
35 \\
70 \\
14\end{array}$ & $\begin{array}{r}0,8 \\
6,3 \\
27,3 \\
54,7 \\
10,9\end{array}$ & 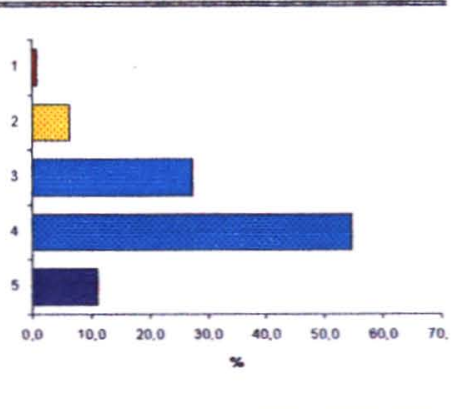 \\
\hline $\begin{array}{l}\text { 20.a. Em geral, } \\
\text { quão satisfeito(a) } \\
\text { você está com } \\
\text { suas relações } \\
\text { pessoais } \\
\text { (familiares, } \\
\text { parentes, } \\
\text { conhecidos, } \\
\text { amigos?) }\end{array}$ & $\begin{array}{c}\text { Muito insatisfeito } \\
\text { Insatisfeito } \\
\text { Nem satisfeito, nem } \\
\text { insatisfeito } \\
\text { Satisfeito } \\
\text { Muito satisfeito }\end{array}$ & $\begin{array}{l}1 \\
2 \\
3 \\
4 \\
5\end{array}$ & $\begin{array}{r}0 \\
8 \\
19 \\
75 \\
26\end{array}$ & $\begin{array}{r}0,0 \\
6,3 \\
14,8 \\
58,6 \\
20,3\end{array}$ & 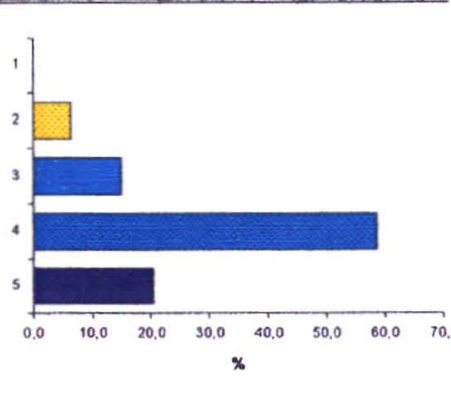 \\
\hline $\begin{array}{l}\text { 20.b. No trabalhg } \\
\text { quão satisfeito(a) } \\
\text { você está com } \\
\text { suas relações } \\
\text { pessoais (alunos } \\
\text { e familiares, } \\
\text { funcionários, } \\
\text { administração, } \\
\text { colegas?) }\end{array}$ & $\begin{array}{c}\text { Muito insatisfeito } \\
\text { Insatisfeito } \\
\text { Nem satisfeito, nem } \\
\text { insatisfeito } \\
\text { Satisfeito } \\
\text { Muito satisfeito }\end{array}$ & $\begin{array}{l}1 \\
2 \\
3 \\
4 \\
5\end{array}$ & $\begin{array}{r}2 \\
7 \\
28 \\
78 \\
13\end{array}$ & $\begin{array}{r}1,6 \\
5,5 \\
21,9 \\
60,9 \\
10,2\end{array}$ & 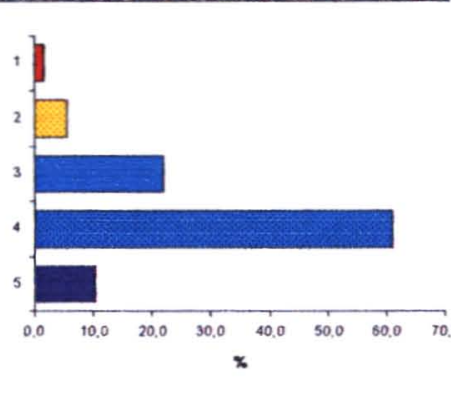 \\
\hline $\begin{array}{l}\text { 21. Quão } \\
\text { satisfeito(a) } \\
\text { você está com } \\
\text { sua vida sexual? }\end{array}$ & $\begin{array}{c}\text { Muito insatisfeito } \\
\text { Insatisfeito } \\
\text { Nem satisfeito, nem } \\
\text { insatisfeito } \\
\text { Satisfeito } \\
\text { Muito satisfeito }\end{array}$ & $\begin{array}{l}1 \\
2 \\
3 \\
4 \\
5\end{array}$ & $\begin{array}{r}1 \\
8 \\
26 \\
68 \\
25\end{array}$ & $\begin{array}{r}0,8 \\
6,3 \\
20,3 \\
53,1 \\
19,5\end{array}$ & (10.0 \\
\hline
\end{tabular}


Tabela 4. Continuação

\begin{tabular}{|c|c|c|c|c|c|}
\hline Perguntas & Respostas & Escores & Freq & $\%$ & Descrição Gráfica \\
\hline $\begin{array}{l}22 \text { Quão } \\
\text { satisfeito(a) } \\
\text { você está com } \\
\text { o apoio que você } \\
\text { recebe de seus } \\
\text { amigos? }\end{array}$ & $\begin{array}{c}\text { Muito insatisfeito } \\
\text { Insatisfeito } \\
\text { Nem satisfeito, nem } \\
\text { insatisfeito } \\
\text { Satisfeito } \\
\text { Muito satisfeito }\end{array}$ & $\begin{array}{l}3 \\
4 \\
5\end{array}$ & $\begin{array}{l}4 \\
23 \\
79 \\
20\end{array}$ & $\begin{array}{r}1,6 \\
3,1 \\
18,0 \\
61,7 \\
15,6\end{array}$ & 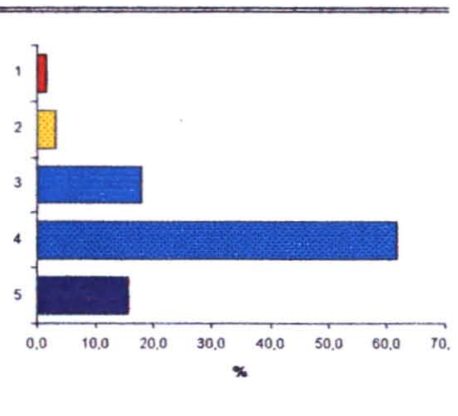 \\
\hline $\begin{array}{l}\text { 23. Quão } \\
\text { satisfeito(a) } \\
\text { você está com } \\
\text { as condições } \\
\text { do local onde } \\
\text { mora? }\end{array}$ & $\begin{array}{c}\text { Muito insatisfeito } \\
\text { Insatisfeito } \\
\text { Nem satisfeito, nem } \\
\text { insatisfeito } \\
\text { Satisfeito } \\
\text { Muito satisfeito }\end{array}$ & $\begin{array}{l}3 \\
4\end{array}$ & $\begin{array}{l}8 \\
13 \\
68 \\
37\end{array}$ & $\begin{array}{r}1,6 \\
6,3 \\
10,2 \\
53,1 \\
28,9\end{array}$ & $\begin{array}{lllllllll} & & & & & & \\
\end{array}$ \\
\hline $\begin{array}{l}24 . \text { Quão } \\
\text { satisfeito(a) } \\
\text { você está com } \\
\text { o seu acesso } \\
\text { aos serviços } \\
\text { de saúde? }\end{array}$ & $\begin{array}{c}\text { Muito insatisfeito } \\
\text { Insatisfeito } \\
\text { Nem satisfeito, nem } \\
\text { insatisfeito } \\
\text { Satisfeito } \\
\text { Muito satisfeito }\end{array}$ & $\begin{array}{l}3 \\
4\end{array}$ & $\begin{array}{l}10 \\
15 \\
30 \\
55 \\
18\end{array}$ & $\begin{array}{r}7,8 \\
11,7 \\
23,4 \\
43,0 \\
14,1\end{array}$ & $\begin{array}{lllllllll} & & & & & \\
\end{array}$ \\
\hline $\begin{array}{l}25 . \text { Quão } \\
\text { satisfeito(a) } \\
\text { você está com } \\
\text { o seu meio de } \\
\text { transporte? }\end{array}$ & $\begin{array}{c}\text { Muito insatisfeito } \\
\text { Insatisfeito } \\
\text { Nem satisfeito, nem } \\
\text { insatisfeito } \\
\text { Satisfeito } \\
\text { Muito satisfeito }\end{array}$ & $\begin{array}{l}1 \\
2\end{array}$ & $\begin{array}{r}7 \\
14 \\
16 \\
60 \\
31\end{array}$ & $\begin{array}{r}5,5 \\
10,9 \\
12,5 \\
46,9 \\
24,2\end{array}$ & 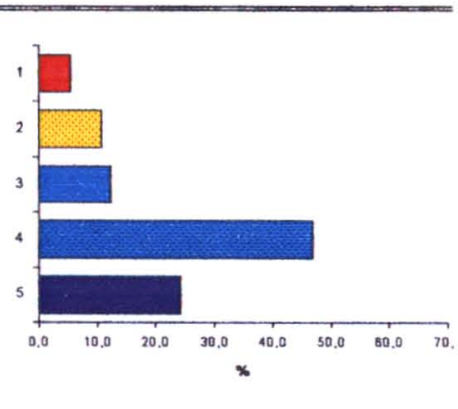 \\
\hline
\end{tabular}


Tabela 4. Continuação

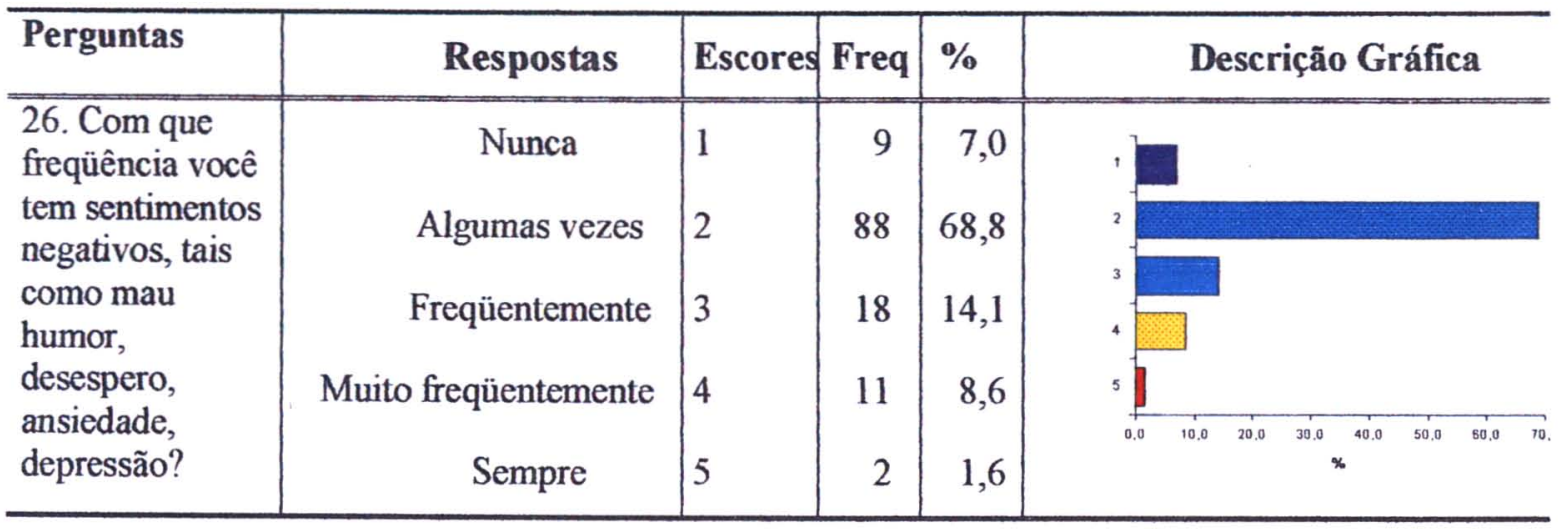

Considerando que os escores 1 e 2 representam condições ruins/deficitárias/negativas dos aspectos da qualidade de vida (exceto nas questões 3, 4 e 26, em que a interpretação deverá ocorrer inversamente), as questões mais comprometidas da qualidade de vida de professores foram, em ordem decrescente: questão 9 - relacionada ao ambiente de trabalho $(54,7 \%)$; 12 condições financeiras $(37,5 \%) ; 14$ - oportunidades de lazer $(35,9 \%) ; 16$ - sono $(21,9 \%) ; 24$ acesso aos serviços de saúde (19,5\%); 25 - meio de transporte $(16,4 \%) ; 2$ - satisfação com a saúde $(14,9 \%)$ e 13 - acesso à informação $(13,3 \%)$. Cabe destacar, aqui, o predomínio dos aspectos da qualidade de vida referentes ao domínio Meio Ambiente, o qual obteve escores mais baixos dentre os demais domínios do QV.

Considerando que o escore 5 representa condições mais favoráveis e positivas dos aspectos da qualidade de vida (exceto nas questões 3, 4 e 26, em que a interpretação deve acontecer ao inverso), as questões com maior ocorrência desse escore foram, em ordem decrescente: questão 15 - capacidade de locomoção (43,8\%); 3 - ausência de dor física $(39,1 \%) ; 6$ - sentido da vida $(38,3 \%) ; 4$ - dispensa tratamento médico $(32,8 \%) ; 23$ - satisfeitos com o local de moradia $(28,9 \%)$.

Nessa tabela, observa-se que a maioria $(65,6 \%)$ dos professores avaliou sua qualidade de vida como boa, e apenas $4,7 \%$ como ruim ou muito ruim.

Para a satisfação com a saúde, nota-se que os resultados são um pouco piores, pois, embora $60,2 \%$ afirmem que estão satisfeitos, $14,9 \%$ dizem estar insatisfeitos ou muito insatisfeitos. Aqui, há que se comentar a discrepância dos dados de auto-avaliação vocal do QVV 
com os dados desse aspecto da qualidade de vida. a satisfacão com a saúde: $39 \%$ aos protery avaliaram a própria voz como razoável ou ruim (e a observação da pesquisadora permitiu perceber que esses sujeitos possuem vozes com algum grau de alteração vocal) e somente $14,9 \%$ se encontram insatisfeitos com a saúde. Isso sugere que a saúde vocal pode não estar sendo considerada, por parcela da população docente, como um aspecto integrante da saúde. Nesse sentido, os dados corroboram as afirmações de GONÇALVES (1996) e CARNEIRO (2001), de que professores têm um conhecimento fragmentado de seu corpo, não dão importância aos avisos desse corpo e que interpretam o conceito de saúde de modo dicotômico.

Aproximadamente $65 \%$ dos professores afirmaram que a dor (fisica) em nada influi ou muito pouco dificulta que eles façam o que precisam. Entretanto, 35,2\% dos professores sofrem dores que os impedem de realizar suas atividades. Foi indagado aos professores que tipo de dor sentiam. Em ordem decrescente, houve prevalência de dores de coluna, dor nas costas e dor de cabeça; seguidas de dor de garganta; dores nas pernas; dores nos braços e, por último, dor na região cervical e dores no corpo todo. Alguns sujeitos possuíam mais do que um tipo de dor. $\mathrm{O}$ estudo de BETANCOURT e PALACIOS (1999), evidenciou alta frequêencia de sintomas fisicos em professores, sendo por volta de $70 \%$ com dores de garganta; $60 \%$ com dores de cabeça; $44 \%$ com dores de estômago, gastrites ou úlceras; e o estudo piloto de SILVANY NETO et al. (1998) mostrou que por volta de $60 \%$ dos professores sofrem dores de garganta, dores nas pernas e rouquidão.

Os sintomas de dores no corpo podem, também, ser resultado da auto-agressão do sujeito, em decorrência de dificuldades em estabelecer relações afetivas mais profundas, conforme apontaram autores como CODO e GAZZOTTI (2000) e VASQUES-MENEZES e GAZZOTTI (2000). Cabe, também, lembrar que por volta de $20 \%$ dos professores demonstraram insatisfação com seu sono e relaxamento, aspecto que BRITO (2000) relaciona também a dores cervicais, dorsais e lombares. Assim, os dados obtidos pelo WHOQOL mostram-se compativeis com a literatura e confirmam o sofrimento fisico e necessidades de saúde do professor em atividade.

Apenas $8,6 \%$ dos professores assinalaram que algum tratamento médico é bastante ou extremamente necessário para que eles consigam levar sua vida diária, enquanto $69,5 \%$ assinalaram os escores 1 ou 2 , que representam nada e muito pouco, respectivamente. A porcentagem de professores que se sentem insatisfeitos com sua saúde também é menor que a 
porcentagem que necessita de tratamento médico para levar a vida diária em graus moderado a extremo (questão 4: 30,5\%). Isso demonstra um problema na percepção do processo saúdedoença vivenciado pelo professor.

Percebe-se que o professor é bastante tolerante quanto aos seus problemas de saúde inclusive os de saúde vocal - e o sofrimento, decorrente do fato de depender de tratamentos ou medicamentos para a vida diária, deixa de causar insatisfação e passa a ser banalizado ou desconsiderado. Haveria, aqui, indícios de uma cultura de "naturalização" do sofrimento e dependência da medicina e de medicamentos para viver o dia-a-dia? Estaria aqui também um dos indícios do que L.EFĖVRE (1995) considera a reificação da saúde e da doença articulada à generalizada medicalização da vida cotidiana?

Em relação a aproveitar a vida, $43 \%$ disseram que aproveitam "mais ou menos", ao passo que somente $2,3 \%$ afirmaram que não aproveitam nada. Foi indagado aos professores o que eles entendem por aproveitar a vida. As respostas indicam algumas categorias: a) Diversão/lazer sub-categorias: passear, viajar, estar/sair com a família, estar/sair com os amigos, dançar, praticar esportes/caminhar, ir ao cinema/teatro; b) Espiritual/emocional - sub-categorias: viver intensamente cada momento, vivenciar sentimentos de harmonia, paz e alegria; c) Investimento pessoal - sub-categoria: cuidar de si, estudar, fazer o que gosta; d) Satisfação no trabalho - subcategorias: boas condições de trabalho, prazer e realização; e) Descanso/dormir bem; f) Saúde sub-categoria: ter saúde, não ter dores. Algumas dessas categorias são relacionadas pelos professores às necessidades de ter tempo e de melhoria das condições financeiras - tais como diversão/lazer e investimento pessoal.

A maioria dos professores assinalou as respostas "bastante" e "extremamente" para a questão $6(89,1 \%)$, o que indica que os professores atribuem sentido às suas vidas. Vislumbrar o sentido da própria vida é um importante fator de resiliência ${ }^{1}$ e de suporte emocional o que, no caso do trabalho docente, poderia contribuir como proteção contra os efeitos da carga mental, do estresse e do burnout, no professor.

\footnotetext{
${ }^{1}$ Resiliência pode ser considerada como uma combinação de fatores ou processos que ajudam os seres humanos a enfrentar e superar os problemas e as adversidades da vida, atuando na prevenção de dificuldades psicoemocionais e de desajustamentos sociais (MORAES e RABINOVICH, 1996).
} 
Os professores responderam "bastante" às questões 7, 8 e 9.a, sendo que as porcentagens foram, respectivamente a cada uma dessas questões, $53,9 \%$; $53,1 \%$ e $60,2 \%$; o que demonstra que os aspectos relacionados a essas questões (capacidade de concentração, sensação de segurança e salubridade do ambiente doméstico) não se configuram tão problemáticos.

Quanto à sensação de segurança, um total de $43 \%$ mostrou variar suas sensações entre "mais ou menos", "muito pouco" e "nada seguros" em sua vida diária. Vale lembrar que a sensação de insegurança pode, aqui, estar relacionada tanto à problemática generalizada da violência urbana, como da violência nas escolas e, portanto, mais diretamente relacionada ao trabalho - o que não exclui a primeira. Esse dado assume maior importância quando relacionado às impressões obtidas durante a primeira fase dessa pesquisa, em especial na Escola 1, que confirmaram os dados de CARNEIRO (2001). Lembrando, ainda, que a violência nas escolas abala o estado emocional de professores e alunos, funcionando como agravante do complexo quadro de trabalho do professor, com conseqüências negativas para sua atuação profissional, vida pessoal e para sua saúde.

Contrastando as respostas das questões 9.a e 9.b, que se referem à quão saudável é o ambiente fisico do professor em casa e no trabalho, respectivamente, nota-se que os professores estão mais satisfeitos com o ambiente de sua casa, pois $78,2 \%$ afirmaram que, em casa, seu ambiente físico é bastante ou extremamente saudável, enquanto apenas $11 \%$ assinalaram essas respostas, quando se trata do trabalho. Quando se refere ao ambiente de trabalho, 54,7\% dos professores consideram o local de trabalho nada ou muito pouco saudável, e tais dados podem envolver aspectos das condições e organização do trabalho docente. Na literatura, diversos autores consideram que o ambiente de trabalho do professor envolve salas quentes, mal ventiladas, com presença de poeira, sujeira, pó de giz, barulho e ruído interno e externo; além de problemas como a agressividade, a falta de respeito, a violência e falta de segurança no local de trabalho (SILVANY et al., 1998; BEHLAU e PONTES, 1999; BRITO, 2000; CARNEIRO, 2001 e ISTO É, 2002), condições adversas à saúde geral e vocal.

A segunda fase desta pesquisa permite explorar melhor a percepção que os professores têm acerca do seu ambiente de trabalho e, nela, os professores referem-se mais aos aspectos sociais, relacionais e da organização do trabalho docente do que aos aspectos do ambiente físico da escola. 
No que diz respeito a ter energia suficiente para o dia-a-dia, cerca de $45 \%$ dos indivíduos assinalaram os itens 4 e 5, "muito" ou "completamente", e nenhum deles afirmou não ter energia para o seu dia-a-dia. Se for considerado que a sensação de perda de energia e de entusiasmo são sentimentos condizentes com um processo de adoecimento, que pode culminar na despersonalização e no burnout (FRANÇA e RODRIGUES, 1999 e VASQUES-MENEZES e GAZZOTTI, 2000), pode-se interpretar que a maioria dos professores desta pesquisa não se encontra nesse processo de adoecimento, fato que é um bom sinal.

Apesar disso, os dados também confirmam a característica desgastante do trabalho docente, quanto ao dispêndio de energia física e psíquica do trabalhador, uma vez que 50\% dos professores sentem que a energia de que dispõem corresponde medianamente às necessidades do seu dia-a-dia. Assim, a questão de reposição de energia física e psíquica do professor é um ponto que merece atenção e cuidado permanente nas ações de prevenção e de promoção da saúde direcionadas a essa categoria profissional.

Quanto à aparência física, 68\% dos professores responderam aceitar "muito" ou "completamente" sua aparência; indicando que a maioria dos sujeitos apresenta uma auto-estima preservada enquanto pessoa.

Em relação a ter dinheiro suficiente para as necessidades cotidianas, 7,8\% responderam "nada" a essa questão, 29,7\% "muito pouco", 49,2\% "médio" e 13,3\% "muito" ou "completamente". Considerando que a questão se refere a necessidades cotidianas - e não a supérfluos- observa-se, aqui, a desvalorização econômica do trabalho do professor, dos quais somente $13,3 \%$ consideram o salário que recebem completamente suficiente para suas necessidades cotidianas. Esse aspecto da qualidade de vida, o qual se apresenta bastante deficitário, foi diretamente relacionado, pelos professores, às respostas da questão 5 (o quanto aproveitam a vida), como deixando a desejar e prejudicando os professores, principalmente nas categorias diversão/lazer e investimento pessoal.

Ainda a respeito de investimento pessoal e lazer, as questões 13 e 14 também demonstram aspectos deficitários da qualidade de vida dos professores. Como profissionais da educação e formadores de pessoas precisam estar bem informados, preparados e capacitados para o 
processo ensino/aprendizagem, mas também precisam ter seus momentos de descontração e lazer.

Na questão 13, referente à disponibilidade de informações de que o professor precisa no seu dia-a-dia, 45,3\% responderam "médio"; e a maioria dos professores $(50,8 \%)$ afirmou que as oportunidades de atividade de lazer são médias enquanto que $35,9 \%$ afirmaram que são poucas ou que não as têm. Assim, entende-se que $86,7 \%$ dos professores têm suas necessidades de lazer apenas razoavelmente satisfeitas.

As respostas às questões 12,13 e 14 do QV evidenciam que, desvalorizado enquanto trabalhador, via remuneração insuficiente às suas necessidades, o professor tem reduzidas suas possibilidades de investimento pessoal, social e profissional e disso se ressente, com implicações que envolvem sua subjetividade, seu bem-estar pessoal, sua auto-estima, além da afetividade, vida familiar, sociabilidade, formação integral e profissional, saúde e qualidade de vida. A problemática da degradação salarial e da desqualificação social do trabalho docente é notória na sociedade brasileira, sendo apontada por vários autores quando abordam as questões de saúde e vida do professor.

Em relação à questão 15 , referente à capacidade de locomoção, a maioria dos professores $(83,6 \%)$ respondeu "bom" ou "muito bom", e somente $0,8 \%$ responderam "muito ruim".

Na questão 16, observa-se que $60,2 \%$ estão "satisfeitos" ou "muito satisfeitos" com o seu sono, ao passo que aproximadamente $40 \%$ estão "não-satisfeitos" e, desses, $21,9 \%$ declaram-se "insatisfeitos" ou "muito insatisfeitos". Cerca de 30\% dos professores lecionam durante três períodos sem contar o tempo despendido no trânsito de casa para a(s) escola(s) - lembrando que, com frequêencia, o professor dá aulas em diferentes escolas e cidades. A isso soma-se o tempo destinado à preparação de aulas, à elaboração de materiais, às leituras e correção de trabalhos e provas, além das responsabilidades domésticas com a casa e a família, o que resulta no fato de que o professor é sobrecarregado de compromissos e tarefas, não lhe restando tempo suficiente para o descanso.

Muitas vezes, o professor deita-se tarde da noite e se levanta muito cedo - contando com um repouso inadequado e insuficiente para garantir-lhe saúde, disposição e bem-estar. O sono 
precário e as alterações do sono relacionam-se a problemas como a fadiga mental e a organização do trabalho docente, especialmente no que diz respeito a jornadas excessivas, poucas pausas durante o periodo de aulas, desvalorização do trabalho realizado e relacionamentos sociais conflituosos e tensos (SOARES JÚNIOR et al., 1994; LIMA, 2001; BORGES, 2001). As situações de demanda constante da jornada sem descanso ou com descanso insuficiente levam, segundo BRITO (2000) e ROTEMBERG et al (2001), a uma permanência constante dos hormônios de adaptação resultando em alteração das fases do sono e da profundidade do descanso noturno.

Em virtude disso, a insuficiência de sono e de relaxamento têm, também, como conseqüência a sensação de cansaço matutino, alterações no ritmo cardíaco, ansiedade, hipertensão, angústia, aumento da contratura muscular ocasionando cefaléia, dores cervicais, dorsais e lombares, bem como aumento da incidência de doenças como gripes, resfriados e infecções das vias aéreas superiores (COUTO e Cols, 1981 e BRITO, 2000). O sono precário relaciona-se com o envelhecimento, com a voracidade na alimentação, com o estresse, com a inibição do sistema imunológico. Diz respeito, também,à elevação da pressão arterial e dos níveis de colesterol ruim (LDL); e com o comprometimento do aprendizado e da memória (VEJA ESPECIAL, 2002). Segundo BEHLAU e PONTES (1999; p. 32), uma noite bem dormida é importante também para o repouso vocal e recuperação de sintomas de fadiga vocal, enquanto que "uma noite mal dormida pode significar uma voz rouca, fraca e com ar pela manhã"

Aproximadamente $55,5 \%$ dos professores estão satisfeitos ou muito satisfeitos com sua capacidade de desempenhar as atividades do seu dia-a-dia, ao passo que somente $10,9 \%$ apresentam algum grau de insatisfação. Por volta de $65,7 \%$ dos professores estão satisfeitos ou muito satisfeitos com sua capacidade para o trabalho, ao passo que somente $11,7 \%$ apresentam algum grau de insatisfação. Isso evidencia que a insatisfação com o sono não vem abalando a disposição e o sentimento de capacidade para desempenhar as atividades e responsabilidades cotidianas, sendo poucos os sujeitos que têm problemas nesse contexto. Aqui, confirmam-se as colocações de autores como SORATTO e OLIVER-HECKLER (2000-b) e de VASQUESMENEZES e GAZZOTTI (2000), de que os professores suportam, por vezes, péssimas condições de trabalho, perdem horas preciosas de sono, deixam ou até se esquecem de alimentar-se, sem medirem esforços para alcançar seus objetivos e pela vontade de promover algo em prol do aluno. 
A maioria dos professores $(65,6 \%)$ respondeu que está satisfeito consigo mesmo (questão 19 ); e somente $7,1 \%$ demonstraram-se algum grau de insatisfação. Professores mostraram-se mais críticos e exigentes consigo mesmos em aspectos gerais do que quanto à sua aparência fisica.

No que tange às questões 20 a 22 , pertinentes ao domínio das relações sociais entre colegas de trabalho, vizinhos, familiares, parentes, amigos e conhecidos, a maioria dos professores respondeu que está satisfeito o que evidencia que contam com uma importante rede de apoio social e senso de coesão de grupo.

HELMAN (1994), SORATTO e RAMOS (2000) e VASQUES-MENEZES e SORATTO (2000), acreditam serem esses fatores de proteção contra o estresse , os que auxiliam a suportar e melhor enfrentar as agruras do trabalho e os conflitos e problemas cotidianos, contribuindo para a satisfação no trabalho e melhoria das condições pessoais com impacto positivo na subjetividade do trabalhador.

Comparando as questões 20 a e 20. b, que dizem respeito à satisfação, com as relações sociais em geral e no trabalho, nota-se que as diferenças são pequenas, sendo que a maior delas se deu na resposta "muito satisfeito" (20,3\% e 10,2\%, respectivamente, para as questões 20 .a e 20 .b, ou seja, maior para as relações pessoais que profissionais). Vale destacar que $71,1 \%$ dos professores encontram-se "satisfeitos" ou "muito satisfeitos" com as relações pessoais no trabalho e apenas $7,1 \%$ afirmam insatisfação nesse campo.

Esses dados não se mostram condizentes com as observações realizadas durante a primeira fase da pesquisa, especialmente na Escola 1; na qual as relações pessoais me pareceram bastante problemáticas. As relações sociais no trabalho envolvem a interação com os alunos, os familiares dos alunos, os colegas professores, o corpo administrativo e os funcionários da escola. São aspectos importantes da organização do trabalho docente e serão melhor investigados na segunda fase dessa pesquisa.

Os professores estão "satisfeitos" ou "muito satisfeitos" (82\%) com as condições do local onde moram e observa-se que $71,1 \%$ estão satisfeitos ou muito satisfeitos com o seu meio de transporte. Ainda que $16,4 \%$ apresentem graus de insatisfação quanto ao meio de transporte, as condições de moradia e transporte despontam como aspectos favorecidos da qualidade de vida dos professores. 
A maioria (68,8\%) afirmou ter "algumas vezes" sentimentos negativos; entretanto, $24,3 \%$ disseram que "freqüentemente", "muito freqüentemente" ou "sempre" têm sentimentos negativos. Os sentimentos negativos, no contexto da docência, podem ser decorrentes do acúmulo de responsabilidades cotidianas; de problemas de indisciplina dos alunos (ESTRELA, 1994; REINHOLD, 1996; FONTANA, 2000 e FURLANI, 2000), ou, ainda, de processos de fadiga mental e depressão, dentre outros (COUTO e Cols., 1981 e SOARES JÚNIOR et al., 1994) ou, ainda, despersonalização (FRANÇA e RODRIGUES, 1999). Dependendo do contexto e da qualidade das relações sociais que despertam tais sentimentos negativos, podem ocorrer interferências na produção da voz.

A Tabela 5 mostra a análise descritiva do Item VIII do questionário SF36, o qual diz respeito a como o indivíduo se sente e como as coisas têm estado nas últimas semanas.

Tabela 5. Análise descritiva das respostas, escores, freqüências e porcentagens atribuídas ao Item VIII do questionário SF36, referente a como o professor se sente e como as coisas têm estado nas últimas semanas.

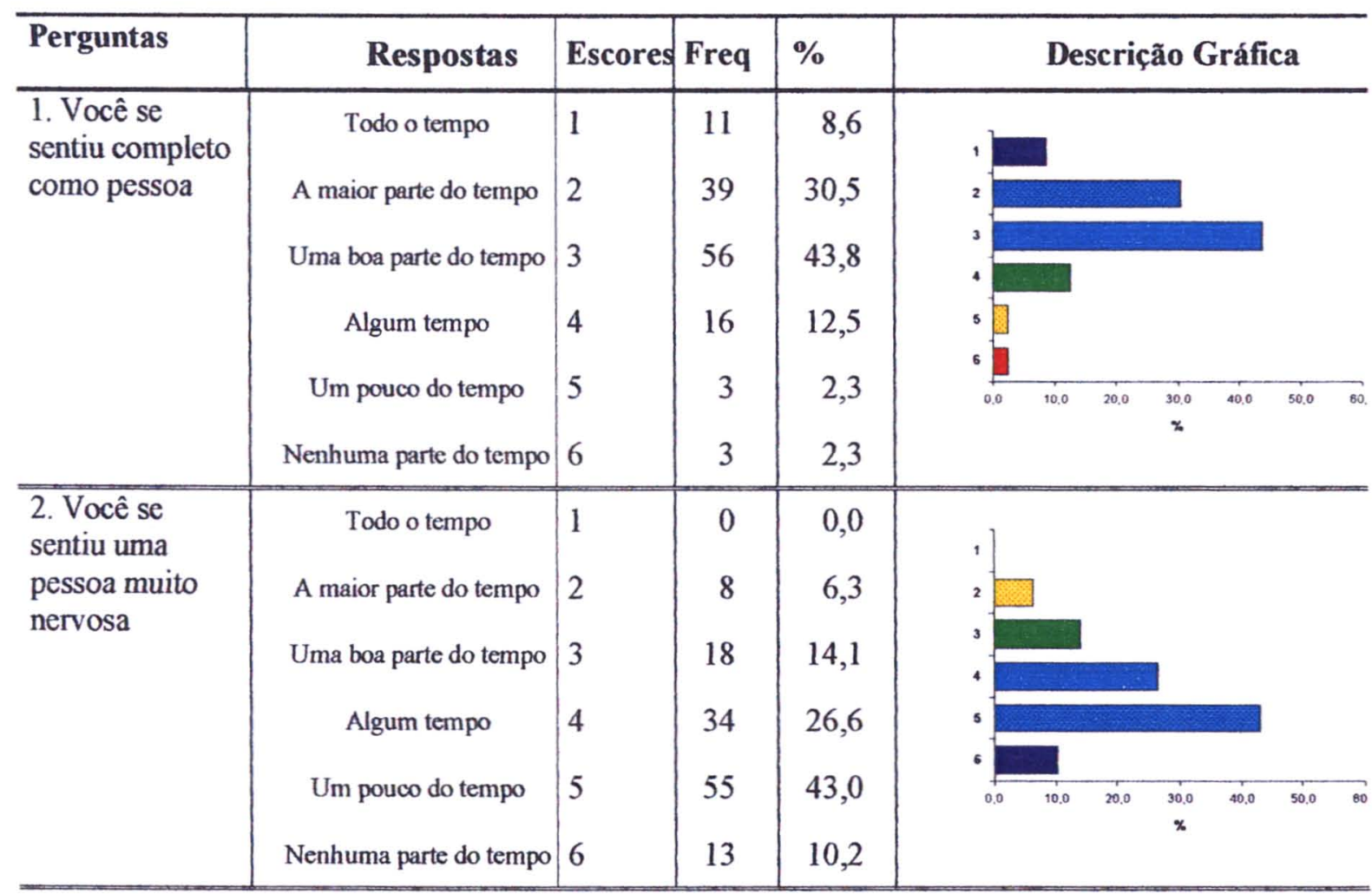


Tabela 5. Continuação

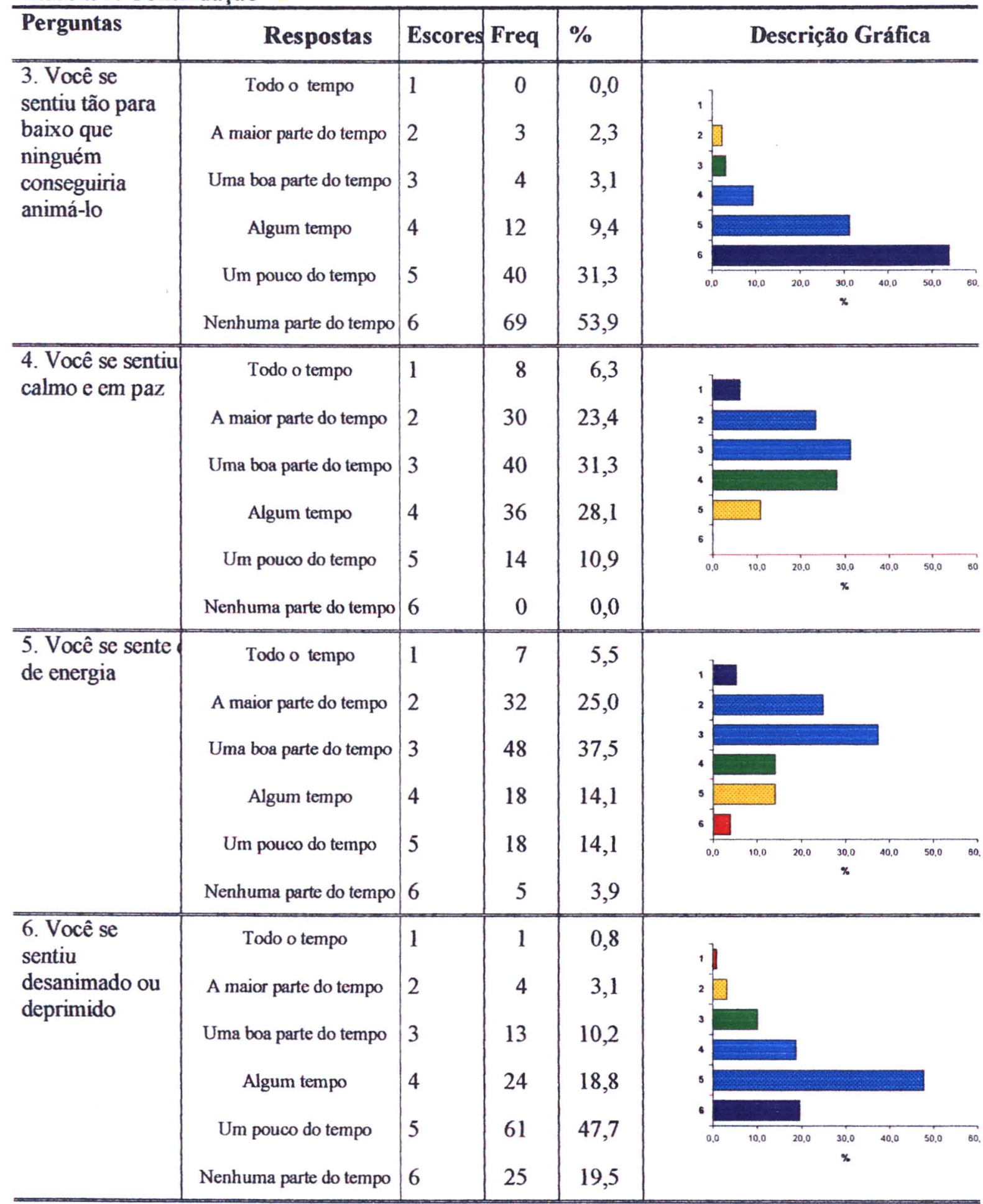


Tabela 5. Continuação

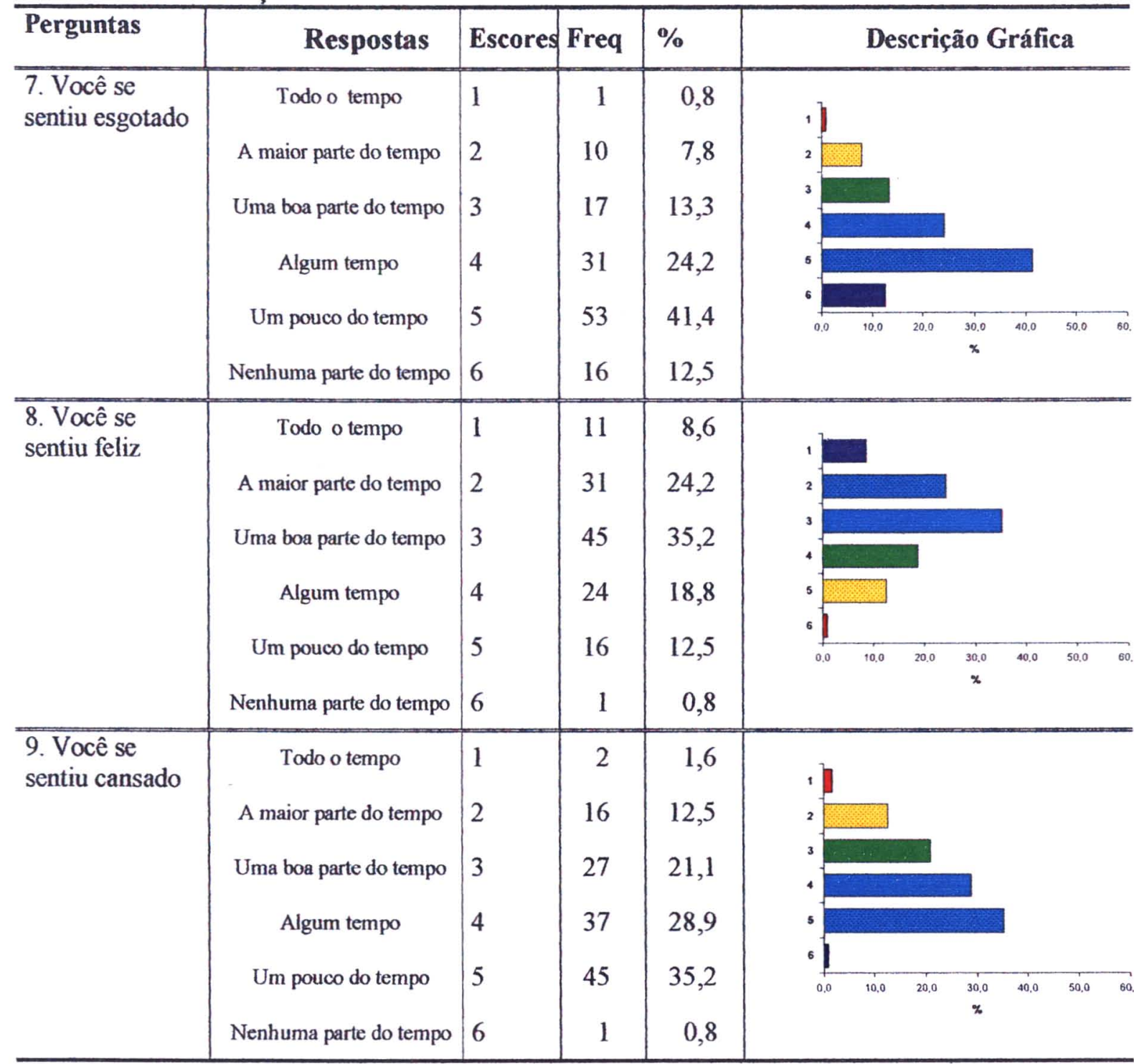

Verifica-se que $8,6 \%$ se sentiram completos como pessoa todo o tempo, $30,5 \%$ a maior parte do tempo e $43,8 \%$ uma boa parte do tempo. Tais dados aproximam-se dos resultados obtidos na questão 19 do Q.V. (quão satisfeito está consigo mesmo).

Em relação à questão 2 , "você sentiu uma pessoa muito nervosa", 53,2\% responderam que "um pouco do tempo" ou "nenhuma parte do tempo", enquanto $20,4 \%$ dos sujeitos responderam "boa parte do tempo" e " a maior parte do tempo". Tais dados aproximam-se daqueles obtidos pela questão 26 do QV (24,3\% freqüentemente com sentimentos negativos). 
A distribuição das respostas da questão 3 é assimétrica, tendendo para o escore 6 , qu站 foi assinalado pela maioria dos professores $(53,9 \%)$, seguido pelos escores $5(31,3 \%)$ e 4 $(9,4 \%)$, o que mostra que o ânimo dos professores está relativamente bom.

$\mathrm{Na}$ questão 4, a distribuição dos escores é relativamente simétrica, com $61,1 \%$ dos sujeitos assinalando que se sentiram calmos e em paz, distribuidos entre sentirem-se assim durante uma boa parte do tempo e todo o tempo.

Dentre os professores, $68 \%$ assinalaram escores menores ou iguais a 3 para responder a questão 5 (você se sente cheio de energia), indicando que os professores são trabalhadores cheios de energia e que esse aspecto não lhes é deficitário. Entretanto, 28,2\% dos sujeitos sentem-se cheios de energia somente durante algum tempo, faltando-lhes energia na maior parte do tempo. Esses dados aproximam-se daqueles da questão 10 do QV - referente a ter energia suficiente para o dia-a-dia.

Quanto à questão 6 (você se sentiu desanimado ou deprimido), 66,5\% assinalaram "algum tempo" ou "um pouco do tempo", ao passo que $24,1 \%$ sentem-se desanimados ou deprimidos de uma boa parte do tempo a todo o tempo. Tais dados aproximam-se daqueles obtidos pela questão 26 do QV (24,3\% freqüentemente com sentimentos negativos). $O$ sentimento de desânimo e de depressão está presente em $80,5 \%$ dos sujeitos, variando a freqüência com que tal sentimento manifesta-se; e isso pode ter implicações negativas sobre a qualidade vocal e as condições de uso da voz. No entanto, as respostas apresentadas pelos sujeitos, na questão 3 desse questionário, indicam que o professor tem encontrado energia disponível para equilibrar os seus sentimentos de desânimo e de depressão, na maioria das vezes em que esses se manifestam.

Aproximadamente $21,9 \%$ dos professores disseram que se sentiram esgotados de "uma boa parte do tempo" a "todo o tempo"; porém $65,6 \%$, teve esse sentimento por algum ou por pouco tempo. Assim, o sentimento de esgotamento está presente em 87,5\% dos professores, em variações de freqüência, dado esse que alerta para a possibilidade de instalação da síndrome de bumout. A porcentagem de $21,9 \%$ de professores esgotados equipara-se com os dados dos 
sujeitos insatisfeitos com o seu sono, na questão 16 do QV; e vale lembrar que o uso da voz sob situações de cansaço e de esgotamento constitui-se num aspecto negativo para a saúde vocal.

Quando se perguntou por quanto tempo o professor se sentiu feliz, 68\% respondeu que entre uma boa parte do tempo e todo o tempo. Para $31,3 \%$ dos sujeitos, esse sentimento ocorre com menor freqüência e um dos sujeitos do grupo analisado nunca se sente feliz. Os momentos felizes são necessários e importantes no enfrentamento das dificuldades e na superação dos sentimentos negativos que atingem o professor; e esse trabalhador conta com momentos de felicidade; porém esses momentos parecem não ser tão freqüentes em seu cotidiano.

Em relação à freqüência de sentimento de cansaço, $35,2 \%$ dos professores sentem-se cansados de uma boa parte do tempo a todo o tempo e por volta de $64,1 \%$ dos sujeitos têm esse sentimento por algum ou pouco tempo. O sentimento de cansaço ocorre, portanto, em $99,2 \%$ dos professores, ainda que a sensação de esgotamento ocorra numa prevalência um pouco menor (por volta de $87 \%$ ). Os dados dessa questão podem estar relacionados aos dados das questões 14 (somente 13,3\% têm oportunidades suficientes de lazer); 16 (55,5\% estão satisfeitos com o seu sono); e 26 (24,3\% têm sentimentos negativos com freqüência) do QV e 2, 3 e 6 do SF36 (respectivamente: $20,4 \%$ nervosos a maior parte do tempo; $14,8 \%$ sentem-se "para baixo" e $24,1 \%$ deprimidos e desanimados).

Apesar do cansaço, as respostas dadas às questões $7,10,17$ e 18 do $\mathrm{QV}$ (respectivamente: capacidade de concentração, reserva de energia e capacidade para desempenhar as tarefas cotidianas e para o trabalho) e às questões 1,5 e 8 do questionário complementar (respectivamente relativas a sentimentos de completude, de energia e de felicidade) indicam que o professor vem encontrando forças - seja no trabalho ou fora dele para não se deixar abater pelo cansaço. Conforme BARDOU DE CARVALHO (1995), quando o professor está satisfeito com o que faz, sente-se menos fatigado e mais realizado pessoalmente, e esses aspectos melhoram sua performance.

Aqui, cabe pensar, também, na possibilidade de que os sentimentos de cansaço e de esgotamento venham sendo "naturalizados" no contexto do exercício da docência, ou seja, que o professor enfrente com naturalidade o fato de se sentir cansado e esgotado e que a 
ocorrência desses sentimentos sejam inerentes ao trabalho de professor; motivos esses que talvez o impeçam de reconhecê-los como problemas a ponto de comprometerem a avaliação de outros aspectos da sua qualidade de vida.

Na Tabela 6, é apresentada a análise descritiva do Item IX do questionário SF36, que trata do quanto a saúde física e os problemas emocionais interferiram nas atividades sociais dos professores nas últimas semanas.

Tabela 6. Análise descritiva das respostas, dadas pelos professores, às perguntas do Item IX do questionário SF 36; bem como os respectivos escores, freqüências e porcentagens, referentes ao quanto a saúde física e os problemas emocionais interferiram nas atividades sociais dos professores, nas últimas duas semanas.

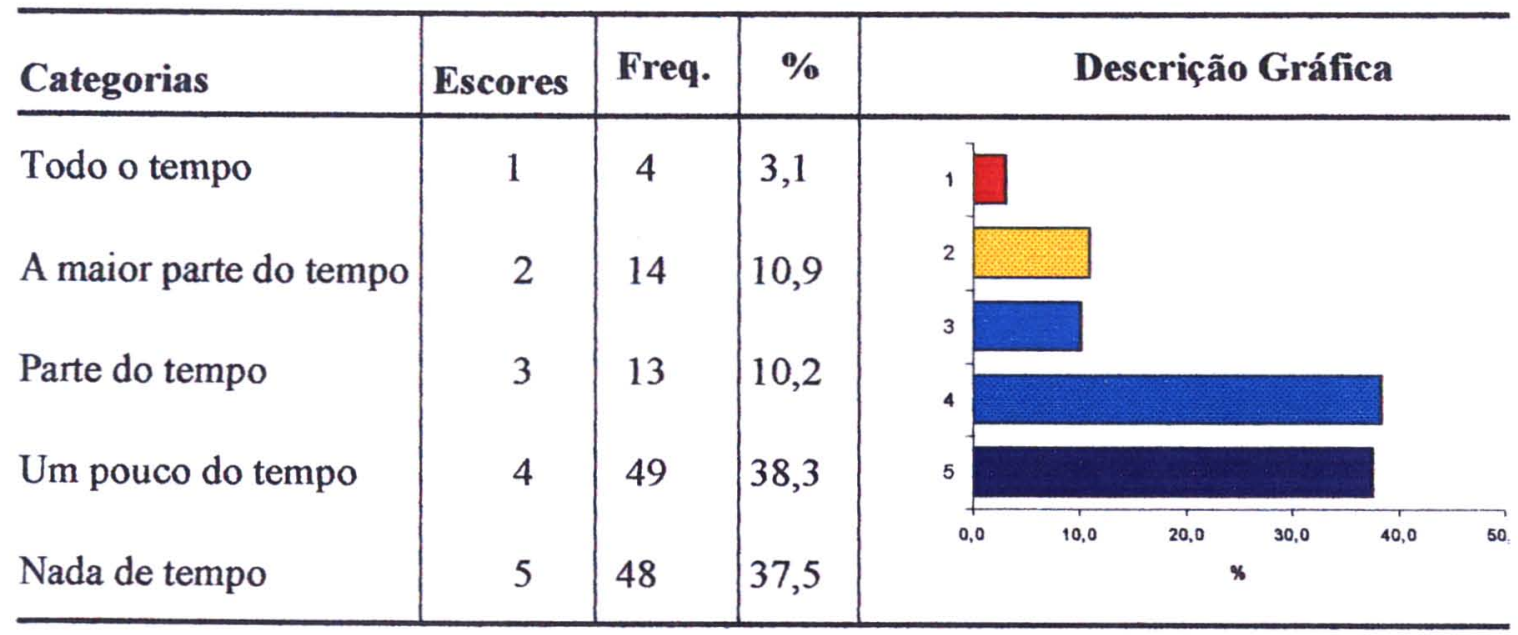

Para $38,3 \%$ dos professores, os problemas de saúde fisica ou emocional interferiram pouco nas atividades sociais; porém, para $24,2 \%$ dos sujeitos os problemas de saúde interferiram, de parcialmente a totalmente na sua vida social, fato que indica que para $62,5 \%$ os problemas de saúde física ou emocional interferiram na vida social. Lembrando que somente $15 \%$ dos professores sentiam-se insatisfeitos com a sua saúde, somos levados a pensar que o impacto negativo da doença sobre a vida social dos sujeitos é um dos aspectos que vem sendo subestimado, quando de trata de avaliar a saúde ou a satisfação com a saúde.

Esses dados da influência dos problemas de saúde física ou emocional na vida social pedem uma nova observação dos dados da questão 8 do QVV $(94,5 \%$ dos professores nunca 
evitam sair socialmente por causa da voz). Dentre os professores, $62,5 \%$ percebern influência dos problemas de saúde física ou emocional na vida social; entretanto, quando se trata de um problema de saúde vocal, parece não haver influência da saúde sobre a vida social, uma vez que $94,5 \%$ deles não se privam de atividades sociais por causa de um problema de voz. Aqui, colocam-se três questões para reflexão:

1) Um problema vocal não exerce impacto limitante sobre as atividades sociais dos professores?

2) A voz não vem sendo considerada por professores como um problema de saúde?

3) O professor apresenta uma dificuldade em perceber a importância e a funcionalidade da voz nas relações interpessoais e, em decorrência disso não tem percepção dos impactos positivos ou negativos da voz nas interações sociais que estabelece no cotidiano?

A segunda fase dessa pesquisa pode contribuir para a elucidação de algumas destas questões. 


\section{3 - Avaliação da consistência dos domínios do QVV - Qualidade de Vida relacionada à Voz}

A Tabela 7 mostra um resumo descritivo dos escores padronizados dos domínios da QVV, enquanto no "Anexo 4" são mostrados os diagramas de "ramos e folhas" dos valores obtidos para esses domínios.

Tabela 7. Análise descritiva dos domínios do QVV - Qualldade de Vida relacionada à Voz

\begin{tabular}{llllrl}
\hline Domínios & Média & $\begin{array}{l}\text { Desvio } \\
\text { Padrão }\end{array}$ & Mediana & Mínimo & Máximo \\
\hline Sócio-emocional & 87,3 & 19,4 & 93,8 & 6,3 & 100,0 \\
Funcionamento Físico & 74,4 & 19,8 & 79,2 & 12,5 & 100,0 \\
Global & 79,6 & 18,2 & 82,5 & 17,5 & 100,0 \\
\hline
\end{tabular}

Observa-se que a média dos domínios do QVV teve o menor valor para o Funcionamento físico $(74,4)$ e o maior valor para o Sócio emocional $(87,3)$, o mesmo ocorrendo para a mediana. De modo geral, observando o domínio Global, pode-se afirmar que os professores tiveram a média dos escores totais da Qualidade de Vida relacionada à Voz (QVV) por volta de 80, com valores variando de 17,5 a 100 . Considerando que os valores melhores seriam os mais próximos de 100, os resultados indicam que, em geral, os professores de Ensino Médio de Rio Claro consideram baixo o impacto negativo da voz sobre a sua qualidade de vida.

A Tabela 8 mostra os coeficientes de correlação de Spearman entre os domínios do QVV.

Tabela 8. Coeficientes de correlação de Spearman e teste " $t$ ", para o cruzamento dos domínios da Qualidade de Vida relacionada à Voz (QVV), dois a dois.

\begin{tabular}{l|cl}
\hline & Funcionamento Físico & Global \\
\hline Sócio-emocional & $0,676^{* *}$ & $0,826^{* *}$ \\
Funcionamento Físico & & $0,959^{* *}$ \\
\hline
\end{tabular}

** = Significativo, pelo teste “" $"$, considerando-se um n.m.s de $1 \%(p \leq 0,01)$. 
As correlações apresentadas na Tabela 8 são fortes e positivas, pois apresentam valores maiores do que 0,6 (CRESPO, 1991). Além disso, os coeficientes de correlação foram significativos ao nível de $1 \%(\mathrm{p} \leq 0,01)$.

Para avaliar a consistência dos domínios da QVV, foram calculados os coeficientes Alpha de Cronbach, considerando todos os domínios em conjunto e, também, pela retirada do i-ésimo domínio. As correlações positivas obtidas na Tabela 8 indicam que a suposição de dessas correlações para o cálculo desse coeficiente não foi violada. Os resultảdos são mostrados na Tabela 9 .

Tabela 9. Análise da consistência dos dominios do QVV - Qualidade de Vida relacionada à Voz.

\section{Indicadores Retirados da Análise}

Coeficiente Alpha de Cronbach

Nenhum

Sócio-emocional

Os dominios da QVV obtiveram um valor geral do Alpha de Cronbach (composto por todos os domínios) de 0,941 , indicando que eles estariam medindo $94,1 \%$ da QVV real dos professores da amostra, o que é excelente. Além disso, não ocorreram grandes mudanças no valor de Alpha com a retirada do i-ésimo domínio (qualquer um deles), pois o menor Alpha foi de 0,825 quando da retirada do domínio Global da análise, e o maior valor de Alpha foi de 0,974 , obtido quando da retirada do domínio Sócio-emocional. Assim, pode-se afirmar que o domínio Sócio-emocional é o que contribui negativamente para a confiança dos domínios da QVV, enquanto o domínio Global é o que mais contribui positivamente.

Aqui, é importante comentar e questionar a organização dos domínios específicos do QVV proposta na literatura, pois causa estranhamento o fato de questões como a 7 (problemas no trabalho ou profissão por causa da voz) não serem inseridas no domínio sócio-emocional, pois os contextos de trabalho ou profissão envolvem questões sociais, interacionais, da auto- 
estima pessoal e da organização social do trabalho. Da mesma maneira, a questão 9 (tenho que repetir o que falo para ser compreendida), pode envolver dificuldades expressivas, discursivas ou relacionais o que, nesse caso, seriam pertinentes ao domínio sócio-emocional. Isso sugere alguns problemas na distribuição dos domínios do QVV e indica que o domínio global é confiável. Assim sendo, talvez a opção de se considerar a análise do QVV pelo domínio Global (scores totais) seja mais interessante do que aquela focalizada nos outros dois domínios específicos.

Por esses motivos, o QVV será referido pelo seu dominio Global na Figura 6 (Faces de "Chemoff"), mais adiante, neste estudo.

\section{4 - Avaliação da consistência dos domínios do WHOQOL/Breve - Qualidade de Vida (QV)}

Na Tabela 10 são mostrados a média, o desvio padrão, a mediana, o mínimo e o máximo, para os escores padronizados dos domínios da QV, ao passo que no "Anexo 4/b" são mostrados os diagramas de "ramos e folhas" dos valores obtidos para esses domínios.

Tabela 10 - Análise descritiva dos domínios de Qualidade de Vida (QV).

\begin{tabular}{llllll}
\hline Domínios & Média & $\begin{array}{l}\text { Desvio } \\
\text { Padrão }\end{array}$ & Mediana & Mínimo & Máximo \\
\hline Físico & 68,6 & 15,9 & 71,4 & 7,1 & 100,0 \\
Psicológico & 68,2 & 12,4 & 66,7 & 29,2 & 100,0 \\
Relações Sociais & 70,3 & 13,3 & 75,0 & 25,0 & 100,0 \\
Meio Ambiente & 56,1 & 12,7 & 56,3 & 25,0 & 90,6 \\
\hline
\end{tabular}

A média dos domínios teve o menor valor para o Meio ambiente $(56,1)$ e o maior valor para as Relações sociais $(70,3)$, o mesmo ocorrendo para a mediana. A maior variação obtida foi no domínio Físico, com desvio padrão de 15,9, valor mínimo de 7,1 e máximo de 100, e a menor variação no domínio Psicológico, com desvio padrão de 12,4, valor mínimo de 29,2 e máximo de 100. Considerando que os valores melhores seriam os mais próximos de 100, os 
resultados indicam que, em geral, os professores de Ensino Médio de Rio Claro encontram-se acima da média na avaliação da qualidade de vida, considerada boa.

Dentre as questões específicas do domínio Meio ambiente, os aspectos que se mostraram mais deficitários ou problemáticos da QV dos professores (escores mais baixos) foram referentes à insalubridade do ambiente de trabalho (Q.9.b), à insuficiência de recursos financeiros para a satisfação das necessidades cotidianas (Q. 12), às restritas oportunidades de lazer (Q.14), seguidos da insatisfação com o acesso aos serviços de saúde (Q. 24).

Dentre as questões específicas do domínio Relações sociais, os aspectos que se mostraram melhores da QV dos professores (escores mais altos) foram, em ordem decrescente, referentes ao apoio dos amigos (Q.22), à vida sexual (Q.21) e às relações sociais no trabalho (Q. 20.b.)

$\mathrm{Na}$ Tabela 11 são mostrados os coeficientes de correlação de Spearman entre os domínios da QV.

Tabela 11. Coeficientes de correlação de Spearman e teste " $t$ ", para o cruzamento dos domínios da Qualidade de Vida (QV), dois a dois.

\begin{tabular}{l|ccc}
\hline & Psicológico & Relaçóes Sociais & Meio Ambiente \\
\hline Físico & $0,538^{* *}$ & $0,280^{* *}$ & $0,459^{* *}$ \\
Psicológico & & $0,511^{* *}$ & $0,479^{* *}$ \\
Relações Sociais & & & $0,398^{* *}$ \\
\hline
\end{tabular}

** = Significativo, pelo teste " $"$ ", considerando-se um n.m.s de 1\% $(\mathrm{p} \leq 0,01)$

Nota-se que, apesar de significativas $(\mathrm{p} \leq 0,01)$, as correlações positivas são somente moderadas, como sugerido por CRESPO (1991), já que apresentam valores variando entre 0,3 e 0,6; à exceção da correlação entre os domínios Físico e Relações sociais $\left(r_{s}=0,280\right)$, que pode ser considerada como uma correlação fraca.

Novamente, para avaliar a consistência dos domínios da QV foram calculados os coeficientes Alpha de Cronbach, considerando todos os domínios em conjunto, e também 
pela retirada do i-ésimo domínio. As correlações positivas obtidas na Tabela 11 indicam que a suposição de correlações positivas para o cálculo desse coeficiente não foi violada. Os resultados são apresentados na Tabela 12 .

Os domínios da QV obtiveram um valor geral do Alpha de Cronbach (composto por todos os domínios) de 0,776 , mostrando que esses domínios estariam medindo $77,6 \%$ da QV real dos professores da amostra, o que é muito bom. Além disso, não ocorreram grandes mudanças no valor de Alpha com a retirada do i-ésimo domínio (qualquer um deles), pois o menor Alpha foi de 0,654 quando se retirou o domínio Psicológico da análise, e o maior valor de Alpha foi de 0,747 , obtido quando se retirou o domínio Físico. Portanto, pode-se afirmar que o domínio Físico é o que menos contribui para a confiança dos domínios da QV, ao passo que o domínio Psicológico é o que mais contribui para ele. O SAS (1999) sugere que valores de Alpha maiores do que 0,70 são aceitáveis. Apenas no domínio Psicológico foi observado um valor de Alpha abaixo desse limite.

Tabela 12. Análise da consistência dos domínios da Qualidade de Vida (QV).

\section{Indicadores Retirados da Análise}

Nenhum

Físico

Psicológico

Relações Sociais

Meio Ambiente

\section{Coeficiente Alpha de Cronbach}

0,776

0,747

0,654

0,743

0,742 


\section{5 - Estudo da associação entre os domínios do WHOQOL/Breve (Qualidade de Vida - QV) e os do QVV (Qualidade de Vida relacionada à Voz)}

A Tabela 13 mostra os coeficientes de correlação de Spearman entre os domínios da QV e da QVV.

Tabela 13. Coeficientes de correlação de Spearman e teste " $t$ ", para o cruzamento dos domínios do QVV com os domínios do WHOQOL/Breve (QV).

\begin{tabular}{l|cccc}
\hline \multirow{2}{*}{$\begin{array}{l}\text { Domínios } \\
\text { da QVV }\end{array}$} & \multicolumn{4}{|c}{ Domínios da QV } \\
\cline { 2 - 5 } & Físico & Psicológico & Relações Sociais & Meio Ambiente \\
\hline $\begin{array}{l}\text { Sócio-emocional } \\
\begin{array}{l}\text { Funcionamento } \\
\text { Físico }\end{array}\end{array}$ & $0,180^{*}$ & $0,296^{* *}$ & $0,099^{\mathrm{ns}}$ & $0,126^{\text {ns }}$ \\
Global & $0,349 * *$ & $0,338^{* *}$ & $0,250^{* *}$ & $0,355^{* *}$ \\
\hline
\end{tabular}

ns = Não significativo, pelo teste ' ', considerando-se um n.m.s. de $5 \%$ ( $p>0,05)$;

* = Significativo, pelo teste ' $t$ ", considerando-se um n.m.s de $5 \%(p \leq 0,05)$;

** = Significativo, pelo teste " $t$ ", considerando-se um n.m.s de $1 \%(p \leq 0,01)$

Observa-se que, à exceção do domínio Sócio-emocional da QVV, que não apresentou correlações lineares significativas (considerando um nível mínimo de significância de 5\%) com os domínios Relações sociais e Meio ambiente, da QV, os demais domínios apresentaram correlações positivas e significativas $(p \leq 0,05)$ entre si. Contudo essas correlações foram, no máximo, moderadas, com a maior representada pela correlação entre o domínio Global da QVV e o domínio Psicológico da QV $\left(r_{s}=0,372\right)$.

A Figura 1 ilustra melhor o ocorrido. 


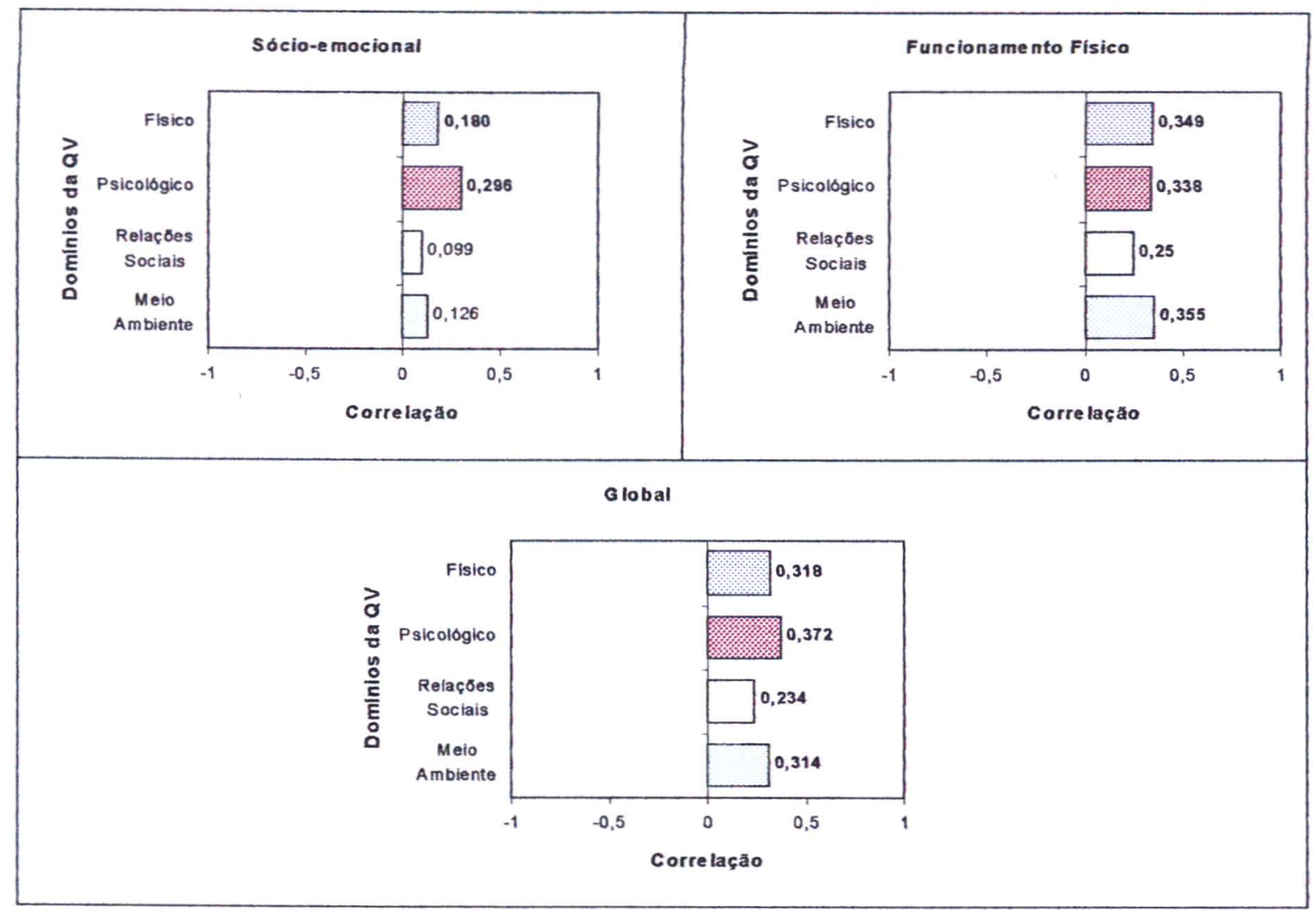

Figura 1. Coeficientes de correlação de Spearman para o cruzamento dos domínios da Qualidade de Vida (QV) com os domínios da Qualidade de Vida relacionada à Voz (QVV). 


\section{6 - Comparação dos sexos}

A Tabela 14 mostra a comparação entre sexos para os domínios da QVV e da QV, pelo teste de Wilcoxon.

Tabela 14. Médias, medianas e desvios padrões para os domínios da Qualidade de Vida relacionada à Voz (QVV) e para os domínios da Qualidade de Vida (QV).

\begin{tabular}{|c|c|c|c|c|c|c|c|c|}
\hline \multirow{3}{*}{\multicolumn{2}{|c|}{ Domínios }} & \multicolumn{6}{|c|}{ SEXO } & \multirow{3}{*}{$\mathbf{p}$} \\
\hline & & \multicolumn{3}{|c|}{ Feminino $(n=89)$} & \multicolumn{3}{|c|}{ Masculino $(n=39)$} & \\
\hline & & Média & Median & Padrão & $\overline{\text { Média }}$ & Mediana & D. Padrão & \\
\hline \multirow{3}{*}{8} & Sócio-emocional & 87,5 & 93,8 & 18,1 & 86,9 & 100,0 & 22,2 & 0,5590 \\
\hline & $\begin{array}{c}\text { Funcionamento } \\
\text { Físico }\end{array}$ & 72,8 & 75,0 & 20,2 & 78,0 & 83,3 & 18,8 & 0,1358 \\
\hline & Global & 78,7 & 82,5 & 17,6 & 81,5 & 90,0 & 19,5 & 0,1546 \\
\hline \multirow{4}{*}{$\vec{z}$} & Físico & 67,9 & 71,4 & 15,4 & 70,1 & 71,4 & 17,0 & 0,6003 \\
\hline & Psicológico & 67,6 & 66,7 & 12,4 & 69,6 & 70,8 & 12,4 & 0,4195 \\
\hline & Relações Sociais & 70,3 & 75,0 & 13,2 & 70,3 & 66,7 & 13,5 & 0,7346 \\
\hline & Meio Ambiente & 55,7 & 53,1 & 12,1 & 57,1 & 59,4 & 14,1 & 0,4119 \\
\hline
\end{tabular}

$\mathrm{p}=$ nivel descritivo de probabilidade do teste de Wilcoxon, sendo considerado que existe diferença significativa entre os sexos quando $p \leq 0,05$.

Apesar de existirem diferenças entre médias e medianas dos dois sexos, para os diversos domínios (valores maiores para o sexo masculino), essas diferenças não foram significativas $(p>0,05)$ pelo teste de Wilcoxon. Isso indica que não há diferenças na qualidade de vida ou no impacto da voz sobre a vida de professores e professoras. Entretanto, isso não deve desqualificar a importância de se levar em conta, nas ações de saúde do trabalhador docente, as questões de gênero na vida e no trabalho da mulher professora, abordadas no capítulo de referencial teórico dessa pesquisa.

O valor médio dos escores da QVV foi 80 (o que é bom) e o valor médio dos escores da QV foi 66 (o que é razoável), levando-se em conta que os escores variavam entre 0 e 100 , considerando homens e mulheres. A qualidade de vida mostra-se pior do que o impacto da voz 
na vida, demonstrando a existência de mais problemas relacionados a aspectos mais amplos da vida do sujeito, do que aqueles decorrentes do impacto da voz. Os dados também sugerem que o impacto negativo da voz sobre a qualidade de vida é pouco percebido por professores(as) do Ensino Médio, os quais se mostram mais críticos na avaliação da sua qualidade de vida do que na avaliação do impacto da voz sobre a sua vida.

O fonoaudiólogo deve buscar conhecer, identificar e considerar os aspectos da vida do sujeito que interferem na sua saúde vocal, ao mesmo tempo em que deve buscar sensibilizar o professor para a percepção dos efeitos e sentidos da voz na sua vida, pois um professor que seja mais sensivel aos efeitos e sentidos da voz, na vida cotidiana e nas relações sociais nela implicadas, teria mais facilidade para avaliar o impacto da sua voz na sua vida de maneira critica, consciente e responsável, o que produziria escores mais baixos no domínio Global do QVV.

Neste sentido, seria interessante que outros estudos pudessem ser realizados investigando a auto-avaliação vocal e o impacto da voz sobre a qualidade de vida em sujeitos pré e pós processo educativo abrangente e integral em promoção da saúde vocal.

Cabe, entretanto, comentar que as médias e medianas do QVV apresentaram-se ligeiramente mais altas para os professores do sexo masculino (Tabela 14) e que, embora as diferenças não tenham se mostrado significativas, confirma-se nessa pesquisa os dados referidos na literatura, uma vez que diversos estudos apontam a prevalência mais alta de problemas vocais em mulheres de diferentes profissões, quando comparados os sexos (SMITH et al, 1998).

0 mesmo ocorre com as questões que envolvem a auto-avaliação da voz (QVV), autoavaliação da qualidade de vida e satisfação com a saúde (questões 1 e 2 do QV, respectivamente) e qualquer uma das demais questões complementares não abrangidas pelos domínios da QVV e da QV; em que se verifica, outra vez, não ter o sexo influenciado significativamente $(p>0,05)$, para afirmar diferenças entre professores e professoras, o que pode ser visualizado mais adiante, na Tabela 15 .

A Figura 2 traz uma ilustração dos resultados dos domínios: 


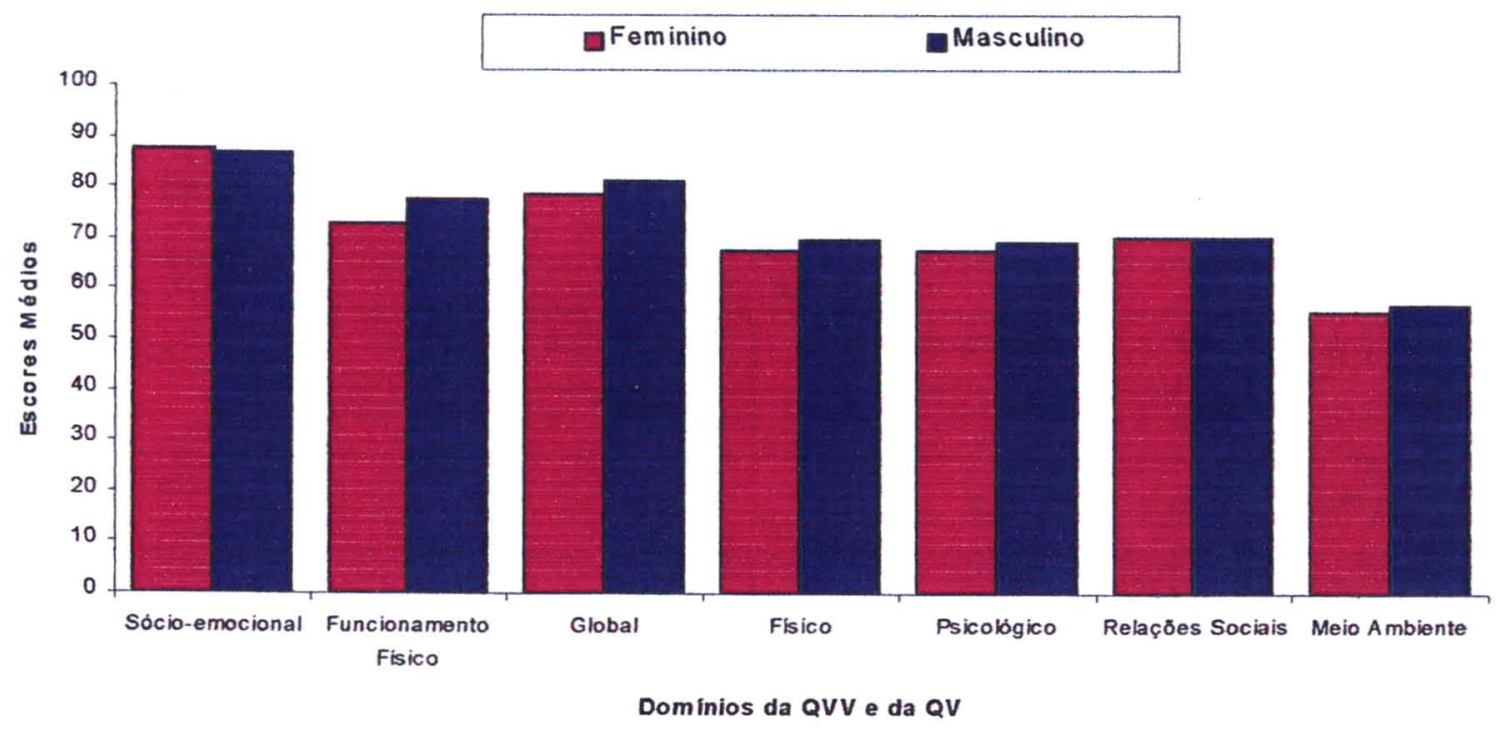

Figura 2. Médias dos domínios da QVV e da QV em função do sexo.

A Tabela 15 mostra as médias, medianas e desvios padrões para as questões não abrangidas pelos domínios da QVV e da QV e questões complementares, em função do sexo, bem como o nível descritivo de probabilidade do teste de Wilcoxon, para comparar os sexos.

Verifica-se, outra vez, que o sexo não influenciou significativamente $(p>0,05)$ qualquer uma das questões. 
Tabela 15. Médias, medianas e desvios padrões para as questões não englobađã per domínios do QVV e do WHOQOL/Breve (QV): a questão como avalia sua voz (QVV); as questões 2, 2, $9^{\mathrm{a}}$ e $20^{\mathrm{a}}(\mathrm{QV})$ e as questões dos itens VIII e IX do SF36, em função do sexo.

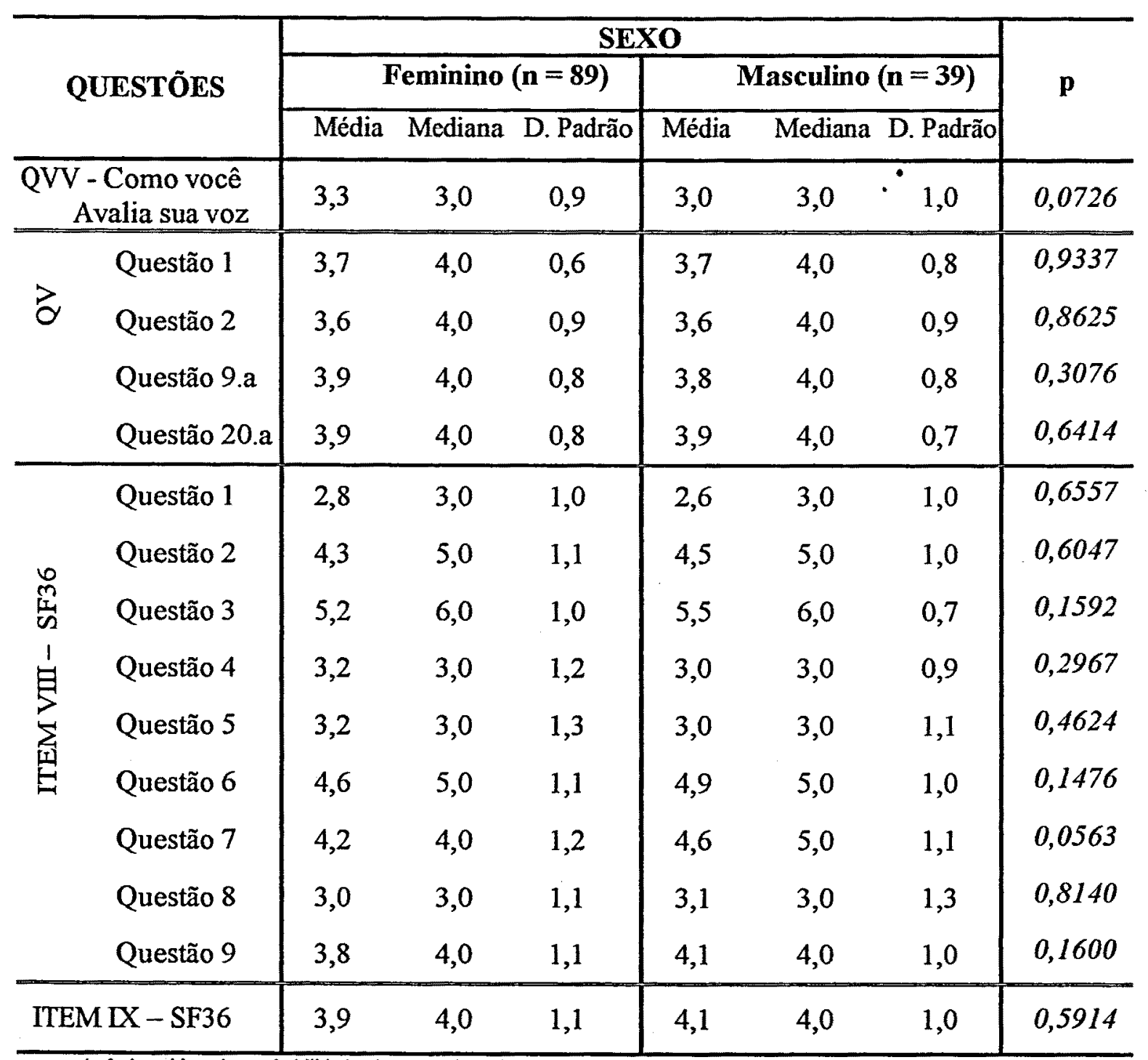

$\mathrm{p}=$ nível descritivo de probabilidade do teste de Wilcoxon, sendo considerado que existe diferença significativa entre os sexos quando $\mathrm{p} \leq 0,05$. 


\section{7 - Associações de idade, número de períodos que leciona e como avalia sua voz com a QVV e a QV}

Na Tabela 16, são mostrados os coeficientes de correlação de Spearman para o cruzamento dos resultados de idade, número de períodos em que leciona, como o professor avalia sua própria voz, como avalia sua qualidade de vida e quão satisfeito está com sua saúde, com os domínios do QVV e QV.

Cabe ressaltar que sempre que a questão "Como avalia sua própria voz" estiver envolvida na correlação com as questões e domínios do QV (exceto as questões 3, 4 e 26 do QV) e dominios do QVV, haverá uma re-interpretação da correlação positiva ou negativa, já que esta questão se encontra invertida em relação às demais. Assim, apresenta-se a correlação tal como ela se dá, porém ajusta-se a sua interpretação.

Tabela 16. Coeficientes de correlação de Spearman e teste " $\mathfrak{t}$ ", para o cruzamento de Idade, $\mathrm{N}^{\circ}$ de períodos que leciona, Como você avalia sua voz, Como você avalia sua qualidade de vida e Quão satisfeito você está com sua saúde, com relação aos domínios da Qualidade de Vida relacionada à Voz (QVV), e aos domínios da Qualidade de Vida (QV).

\begin{tabular}{|c|c|c|c|c|c|c|}
\hline & Domínios & $\begin{array}{l}\text { Idade } \\
\text { (Anos) }\end{array}$ & $\begin{array}{c}\text { N. } .^{\circ} \text { de } \\
\text { Períodos }\end{array}$ & $\begin{array}{l}\text { Como você } \\
\text { avalia sua voz }\end{array}$ & $\begin{array}{c}\text { Como você } \\
\text { avalia sua } \\
\mathbf{Q V}\end{array}$ & $\begin{array}{l}\text { Quão satisfeito } \\
\text { você está com } \\
\text { sua saúde }\end{array}$ \\
\hline \multirow{3}{*}{8} & Sócio-emocional & $-0,007^{\mathrm{ns}}$ & $-0,146^{\mathrm{ns}}$ & $-0,498 * *$ & $0,243 * *$ & $0,257 * *$ \\
\hline & $\begin{array}{c}\text { Funcionamento } \\
\text { Físico }\end{array}$ & $0,072^{\mathrm{ns}}$ & $-0,147^{\mathrm{ns}}$ & $-0,673 * *$ & $0,298 * *$ & $0,310 * *$ \\
\hline & Global & $0,067^{\mathrm{ns}}$ & $-0,149^{n s}$ & $-0,672 * *$ & $0,326 * *$ & $0,318 * *$ \\
\hline \multirow{4}{*}{8} & Físico & $-0,147^{\mathrm{ns}}$ & $-0,026^{\mathrm{ns}}$ & $-0,354 * *$ & $0,258 * *$ & $0,590 * *$ \\
\hline & Psicológico & $-0,151^{\mathrm{ns}}$ & $-0,023^{\mathrm{ns}}$ & $-0,263 * *$ & $0,292 * *$ & $0,406 * *$ \\
\hline & Relações Sociais & $-0,075^{\mathrm{ns}}$ & $-0,183 *$ & $-0,181 *$ & $0,188 *$ & $0,201 *$ \\
\hline & Meio Ambiente & $0,013^{\mathrm{ns}}$ & $0,003^{\text {ns }}$ & $-0,320 * *$ & $0,425 * *$ & $0,349 * *$ \\
\hline
\end{tabular}

ns = Não significativo, pelo teste " $"$ ", considerando-se um n.m.s. de $5 \%(p>0,05)$;

* = Significativo, pelo teste " $"$ ", considerando-se um n.m.s de $5 \%(\mathrm{p} \leq 0,05)$;

** = Significativo, pelo teste “ 4 ", considerando-se um n.m.s de $1 \%(p \leq 0,01)$. 
As correlações lineares entre a idade e os domínios da QVV e da QV não foram significativas, considerando um nível mínimo de significância de $5 \%(p>0,05)$, em todos os casos, indicando que não existe correlação linear entre a idade e os domínios.

$\mathrm{O}$ número de períodos de trabalhado professor apresentou correlação negativa e significativa ( $\mathrm{p}$ 0,05), somente com o domínio Relações Sociais da QV. Apesar de ser uma correlação fraca, esse resultado indica que quanto mais o professor leciona, menos satisfeito ele está com as suas relações sociais. Vale lembrar, aqui, que o domínio Relações Sociais da QV engloba as questões 20,21 e 22 , as quais se referem às relações com familiares, amigos, colegas, alunos e funcionários e à vida sexual do(a) professor(a).

Quanto à resposta da pergunta: Como você avalia sua voz?, nota-se que existiram correlações negativas e significativas $(p \leq 0,05)$ em todas as situações. As correlações mais fortes foram com os domínios Funcionamento físico $\left(r_{s}=-0,673\right)$ e Global $\left(r_{s}=-0,672\right)$ da QVV, seguidas por correlações moderadas com os domínios Sócio-emocional da QVV $\left(\mathrm{r}_{\mathrm{s}}=\right.$ $0,498)$, Físico $\left(r_{s}=-0,354\right)$ e Meio ambiente $\left(r_{s}=-0,320\right)$ da $Q V$, e por correlações fracas com os domínios Psicológico $\left(r_{s}=-0,263\right)$ e Relações sociais $\left(r_{s}=-0,181\right)$, ambos da QV. Isso mostra que, quanto pior é a avaliação que o professor faz da própria voz, pior é sua qualidade de vida relacionada à voz, como era esperado, sendo também pior a sua qualidade de vida.

Quanto à pergunta: Como você avalia sua qualidade de vida?, há correlações positivas e significativas moderadas com os domínios Meio ambiente $\left(r_{s}=0,425\right)$ e Psicológico $\left(r_{s}=\right.$ $0,298)$ da QV e Global $\left(r_{s}=0,326\right)$ e Físico $\left(r_{s}=0,258\right)$ da QVV. Isso indica que quanto pior é a avaliação que o sujeito faz da sua qualidade de vida, piores se encontram as suas condições físicas, ambientais, psicológicas e, também pior, é o impacto negativo da voz sobre a sua qualidade de vida. A correlação permite também considerar que, quanto piores as condições da qualidade de vida, pior a auto-avaliação da voz, ou seja, piores as condições de saúde vocal. Isso nos leva a reconsiderar a abrangência das questões envolvidas na avaliação do impacto da voz na vida de um sujeito, e do impacto da qualidade de vida sobre sua saúde vocal, ao mesmo tempo em que os aspectos concorrentes, especialmente aqueles referentes aos domínios Psicológico e Meio ambiente da qualidade de vida dos sujeitos, devem ser, também, levados em conta. Nesse sentido, as questões dos domínios específicos do WHOQOL/Breve podem referenciar alguns temas para reflexão... 
A questão "Quão satisfeito está com sua saủde?" apresenta correlação positiva e significativa moderada com todos os domínios avaliados: domínios Físico $\left(r_{\mathbf{s}}=0,590\right)$; Psicológico $\left(r_{s}=0,406\right)$ e Meio ambiente $\left(r_{s}=0,349\right)$ da QV e domínios Global $\left(r_{s}=0,318\right)$ e Funcionamento físico $\left(\mathrm{r}_{\mathrm{s}}=0,310\right)$ da QVV. Isso significa que quanto pior é a satisfação com a saúde, pior está a qualidade de vida e pior é o impacto da voz sobre a qualidade de vida do sujeito, e vice-versa.

A Figura 3 permite visualizar melhor o que ocorreu: 


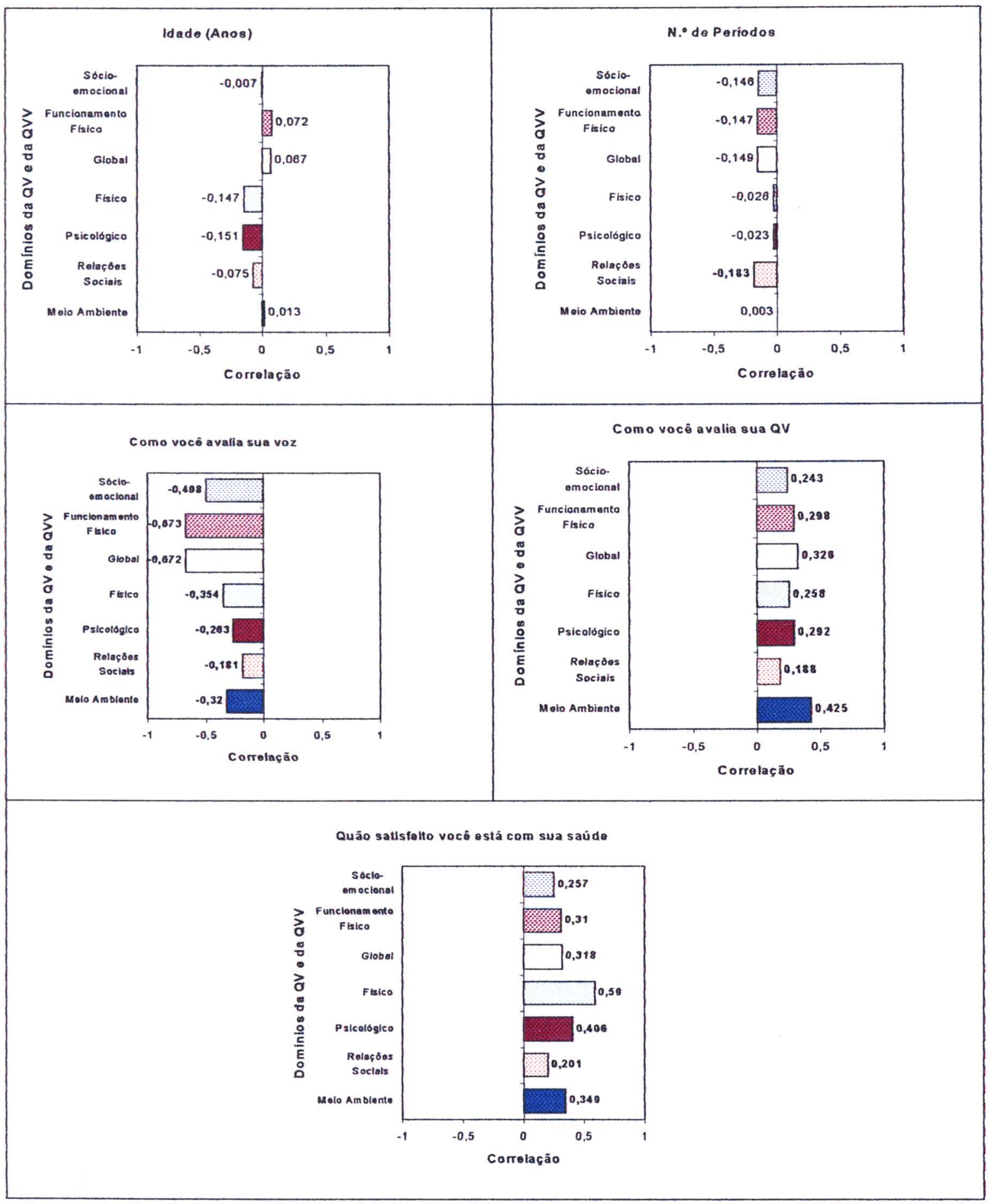

Figura 3. Coeficientes de correlação de Spearman para o cruzamento de Idade, $\mathrm{N}^{\circ}$ de períodos que leciona, Como você avalia sua voz, Como você avalia sua qualidade de vida e Quão satisfeito você está com sua saúde, com os domínios da Qualidade de Vida relacionada à Voz (QVV), e com os domínios do WHOQOL/Breve - Qualidade de Vida (QV). 
A Tabela 17 apresenta os coeficientes de correlação de Spearman para o cruzament: de Idade, $N .^{\circ}$ de periodos em que leciona e Como o professor avalia sua própria voz, Como você avalia sua qualidade de vida e Quão satisfeito você está com sua saúde, com as questões não abrangidas pelos domínios da QVV e da QV.

Tabela 17. Coeficientes de correlação de Spearman e teste " $t$ ", para o cruzamento de Idade, $\mathrm{N} .^{\circ}$ de períodos em que leciona, Como você avalia sua voz, Como você avalia sua qualidade de vida e Quão satisfeito você está com sua saúde, com questões não englobadas pelos domínios da Qualidade de Vida relacionada à Voz (QVV), e pelos os domínios da Qualidade de Vida (QV).

\begin{tabular}{|c|c|c|c|c|c|c|}
\hline \multicolumn{2}{|c|}{ Questões } & $\begin{array}{l}\text { Idade } \\
\text { (Anos) }\end{array}$ & $\begin{array}{l}\text { N. }{ }^{\circ} \text { de } \\
\text { Períodos }\end{array}$ & $\begin{array}{c}\text { Como você } \\
\text { avalia sua } \\
\text { voz } \\
\end{array}$ & $\begin{array}{c}\text { Como você } \\
\text { avalia sua } \\
\text { QV }\end{array}$ & $\begin{array}{l}\text { Quão satisfeito } \\
\text { você está com } \\
\text { sua saúde } \\
\end{array}$ \\
\hline \multicolumn{2}{|c|}{ Como você avalia sua voz } & $0,090^{\mathrm{ns}}$ & $0,244 * *$ & - & $-0,306 * *$ & $-0,349 * *$ \\
\hline \multirow{4}{*}{$z$} & Questão 1 & $-0,122^{\mathrm{ns}}$ & $-0,046^{\text {ns }}$ & $-0,306 * *$ & - & $0,347 * *$ \\
\hline & Questão 2 & $-0,105^{\mathrm{ns}}$ & $-0,198 *$ & $-0,349 * *$ & $0,347 * *$ & - \\
\hline & Questão 9.a & $-0,046^{\mathrm{ns}}$ & $0,041^{\text {ns }}$ & $-0,160^{\mathrm{ns}}$ & $0,082^{\mathrm{ns}}$ & $0,034^{\mathrm{ns}}$ \\
\hline & Questão 20.a & $-0,079^{\text {ns }}$ & $-0,075^{\mathrm{ns}}$ & $-0,275 * *$ & $0,193 *$ & $0,168^{\mathrm{ns}}$ \\
\hline \multirow{10}{*}{ 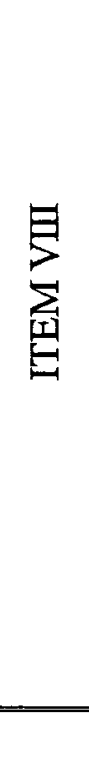 } & Questão 1 & $0,089^{\mathrm{ns}}$ & $-0,022^{\text {ns }}$ & $0,255 * *$ & $-0,267 * *$ & $-0,396 * *$ \\
\hline & Questão 2 & $-0,051^{\mathrm{ns}}$ & $0,043^{\mathrm{ns}}$ & $-0,100^{\text {ns }}$ & $-0,053^{\mathrm{ns}}$ & $-0,189 *$ \\
\hline & Questão 3 & $-0,143^{\mathrm{ns}}$ & $0,003^{\text {ns }}$ & $-0,143^{\mathrm{ns}}$ & $0,096^{\mathrm{ns}}$ & $0,239 * *$ \\
\hline & Questão 4 & $-0,029^{n s}$ & $-0,020^{n s}$ & $0,168^{\text {ns }}$ & $-0,109^{n s}$ & $-0,445 * *$ \\
\hline & Questão 5 & $-0,038^{n s}$ & $-0,040^{\text {ns }}$ & $0,273 * *$ & $-0,145^{\text {ns }}$ & $-0,395 * *$ \\
\hline & Questão 6 & $-0,023^{\mathrm{ns}}$ & $-0,097^{\mathrm{ns}}$ & $-0,324 * *$ & $0,145^{\mathrm{ns}}$ & $0,422 * *$ \\
\hline & Questão 7 & $0,057^{\mathrm{ns}}$ & $-0,155^{\mathrm{ns}}$ & $-0,258 * *$ & $0,160^{\text {ns }}$ & $0,370 * *$ \\
\hline & Questão 8 & $0,146^{\mathrm{ns}}$ & $-0,001^{\mathrm{ns}}$ & $0,184 *$ & $-0,264 * *$ & $-0,381 * *$ \\
\hline & Questão 9 & $0,087^{\mathrm{ns}}$ & $-0,156^{\mathrm{ns}}$ & $-0,258 * *$ & $0,212 *$ & $0,441 * *$ \\
\hline & ITEM IX & $-0,069^{\mathrm{ns}}$ & $-0,015^{\mathrm{ns}}$ & $-0,204 *$ & $0,249 * *$ & $0,374 * *$ \\
\hline
\end{tabular}

ns = Não significativo, pelo teste "t", considerando-se um n.m.s. de $5 \%(p>0,05)$;

* = Significativo, pelo teste " $\mathrm{t}$ ", considerando-se um n.m.s de $5 \%$ (p $\leq 0,05)$;

** = Significativo, pelo teste “ $t$ ”, considerando-se um n.m.s de $1 \%(p \leq 0,01)$. 
A observação da Tabela 17 permite verificar que, novamente, a idade não apresentou correlação linear significativa $(p>0,05)$ com qualquer uma das questões, o que mostra não ser essa variável importante para a qualidade de vida, e para a qualidade de vida relacionada à voz, na faixa etária da população envolvida nesse estudo (entre 20 e 60 anos). É possível que em populações com idades acima de 60 anos ou idosos as correlações passem a ser significativas, uma vez que podem envolver as questões próprias do envelhecimento humano e também da presbifonia, que implica em uma série de alterações estruturais na laringe, com menọr ou maior impacto vocal em cada pessoa (BEHLAU, 1999).

Em relação ao número de períodos em que o professor leciona, observa-se que esse quesito se mostrou correlacionado, positiva e significativamente $(p \leq 0,01)$, apenas com as respostas da questão nas quais o professor avalia a própria voz. Portanto, mesmo a correlação sendo fraca, pode-se afirmar que, quanto mais o professor trabalha, pior é a avaliação que ele faz da própria voz. Aqui, se considerarmos que a maioria dos sujeitos que avaliaram suas vozes como razoáveis ou ruins apresentavam vozes disfônicas, pode-se inferir que o fato de trabalhar mais aumenta o risco para alterações vocais. Isso não acontece numa relação linear de causalidade entre uso e abuso vocal e disfonia, mas levando-se em conta que o professor que trabalha mais está exposto à maior quantidade e diversidade de problemas e conflitos, envolve-se com mais compromissos e responsabilidades, tem menos tempo livre para o lazer, descanso ou para alimentar-se tranqüilamente e tem a interferência da carga de trabalho elevada nas suas relações familiares e sociais, o que pode aumentar conflitos, bem como o seu grau de frustração e insatisfação no campo das relações interpessoais, com reflexos sobre as condições de uso da voz e saúde vocal.

As respostas da questão Como o professor avalia a própria voz não apresentaram correlações significativas ( $p>0,05$ ) somente com as questões 9. a (da QV), e 2, 3 e 4 (do Ítem VIII - SF36). Algumas correlações foram negativas e moderadas, como com a questão 2 da QV $\left(r_{s}=-0,349\right)$ com a questão 6 do Ítem VIII - SF $36\left(r_{s}=-0,324\right)$ e com a questão 1 da QV $\left(r_{s}=-0,306\right)$; enquanto a maioria delas pode ser classificada como fraca. Esses resultados evidenciam que, quanto melhor a voz e a saúde vocal do professor, melhor é a sua qualidade de vida e melhor é a avaliação do impacto da voz sobre a sua qualidade de vida, fato que 
significa que a voz exerce menos impacto sobre a vida do sujeito. Afirma-se, portanto, uma correlação entre voz/saúde vocal e qualidade de vida do professor de ensino médio.

A questão Como o professor avalia a sua qualidade de vida apresenta uma correlação moderada significativa e positiva, a questão 2 da $Q V\left(r_{s}=0,347\right)$, e negativa com a questão de como avalia a própria voz do QVV $\left(\mathrm{r}_{\mathrm{s}}=-0,306\right)$, além das correlações negativas e fracas com as questões 1 e 8 (Item VIII-SF36) e a questão única do Item IX-SF36. Assim, evidencia-se que, quanto pior a avaliação que o professor faz da sua qualidade de vida, mais insatisfeito ele está com a sua saúde, pior estáa a sua voz e sua saúde vocal, menos ele se sente completo como pessoa, mais os seus problemas de saúde interferem na sua vida social e mais infeliz o professor está. Mais uma vez, evidencia-se a relação existente entre a saúde vocal, saúde geral e qualidade de vida do professor.

A questão Quão satisfeito o professor está com a sua saúde apresenta correlação significativa positiva moderada com a maioria das questões complementares e não envolvidas nos domínios da QVV e QV. Isso representa que, quanto maior a satisfação do professor com sua saúde, mais fortes são seus sentimentos de tranqüilidade, paz e de completude como pessoa, menos ele se sente deprimido ou cansado e mais energia ele tem. Aqui, evidencia-se a inter-relação entre aspectos psico-emocionais e de subjetividade e a saúde geral do professor, bem como a importância de serem levados em conta tais aspectos na avaliação da saúde/saúde vocal do professor.

$\mathrm{Na}$ Tabela 18, observa-se o cruzamento da questão Como você avalia sua voz, com questões englobadas pelos instrumentos de avaliação da Qualidade de Vida relacionada à Voz (QVV), e de avaliação da Qualidade de Vida (WHOQOL/Breve). As correlações lineares entre a questão isolada "Como avalia sua voz" com as questões do QVV e do WHOQOL/Breve foram, na maioria, significativas, considerando um nível mínimo de significância de 5\% ( $p>$ 0,05 ). 
Tabela 18. Coeficientes de correlação de Spearman e teste " $t$ ", para o cruzamento de Como você avalia sua voz, com questões englobadas pelos instrumentos de avaliação da Qualidade de Vida relacionada à Voz (QVV), e de avaliação da Qualidade de Vida (QV).

\begin{tabular}{|c|c|c|c|c|c|}
\hline \multicolumn{6}{|c|}{ Qualidade de Vida e Voz (QVV) } \\
\hline Questão 1 & $0,619^{\star \star}$ & Questäo 5 & $0,408^{* *}$ & Questão 8 & $0,103^{\text {ns }}$ \\
\hline Questão 2 & $0,481 * *$ & Questão 6 & $0,351 * \star$ & Questão 9 & $0,346^{* *}$ \\
\hline Questão 3 & $0,547^{* *}$ & Questão 7 & $0,543^{* *}$ & Questão 10 & 0,339 ** \\
\hline Questão 4 & $0,488^{* *}$ & & & & \\
\hline \multicolumn{6}{|c|}{ Qualidade de Vida (QV) } \\
\hline Questão 1 & $-0,306^{\star \star}$ & Questão 10 & $-0,360^{* *}$ & Questão 19 & $-0,284^{* \star}$ \\
\hline Questão 2 & $-0,349^{\star *}$ & Questão 11 & $-0,34 T^{\star \star}$ & Questão 20. & $-0,323^{\star *}$ \\
\hline Questão 3 & $0,250 * *$ & Questão 12 & $-0,207^{*}$ & Questão 21 & $-0,168^{n s}$ \\
\hline Questão 4 & $0,178^{*}$ & Questão 13 & $-0,206^{*}$ & Questão 22 & $0,079^{\mathrm{ns}}$ \\
\hline Questão 5 & $-0,145^{\mathrm{ns}}$ & Questão 14 & $-0,176^{*}$ & Questão 23 & 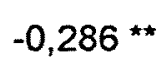 \\
\hline Questão 6 & $-0,112^{\mathrm{ns}}$ & Questão 15 & $-0,146^{\mathrm{ns}}$ & Questão 24 & $-0,088^{n s}$ \\
\hline Questão 7 & $-0,208$ * & Questão 16 & $-0,229 * *$ & Questão 25 & $-0,128^{n s}$ \\
\hline Questão 8 & $-0,176 *$ & Questão 17 & $-0,299 * *$ & Questão 26 & $0,008^{\mathrm{ns}}$ \\
\hline Questão 9.b & $-0,251^{\star *}$ & Questão 18 & $-0,224 *$ & & \\
\hline
\end{tabular}

Em relação às questões do QVV, houve correlação positiva significativa, de forte a moderada para todas as questões, exceto para a de $n^{\circ} 8$, em que a correlação não foi significativa. As correlações mais fortes ocorreram com as questões 1, 3, 7, 4, 2 e 5; as demais mostraram-se moderadas. É interessante observar que a terceira correlação significativa mais forte ocorre com a questão 7 , relacionada ao impacto da voz no trabalho docente.

Isso indica que, quanto pior o sujeito avalia a sua voz, piores se encontram suas dificuldades para falar e realizar a coordenação pneumofonoarticulatória; maiores são seus problemas expressivos, comunicativos ou profissionais relacionados à voz e piores estão seus sentimentos negativos como frustração, depressão e vice-versa.

A correlação aqui encontrada permite sugerir a utilização da pergunta "Como você avalia sua voz?", em triagens fonoaudiológicas coletivas, nas quais não seja possível ou necessário, num primeiro momento, aplicar o questionário QVV ou realizar a avaliação vocal 
de uma população ou comunidade. As respostas a essa questão também forneceriam dados para agrupamentos e seleção de sujeitos com maiores necessidades em saúde vocal, para organização e planejamento de ações coletivas em saúde vocal do professor.

A questão "Como avalia sua voz" apresentou correlação negativa significativa com as questões do QV ( $\leq 0,01)$, variando entre moderada (questões $10,2,11,20 \mathrm{~b}, 1)$ e fraca (questões 17, 23, 19, 9b, 3 e 16). Não houve correlação significativa com as questões 5, 6, 15, $21,22,24,25$ e 26 . Isso representa que, quanto melhor é a avaliação que o professor faz da própria voz, mais energia e capacidade ele tem para enfrentar o seu dia-a-dia; maior é a satisfação com a saúde, consigo e com sua aparência fisica; maior é a satisfação com as relações e condições do local de trabalho; com o local de moradia e com a qualidade de vida. $\mathrm{O}$ inverso também é verdadeiro, evidenciando, mais uma vez, a necessidade premente de se considerar a saúde vocal do professor numa perspectiva mais ampla e mais abrangente, relacionada às suas condições de vida e trabalho.

\section{8 - Comparação das escolas}

Na Tabela 19 são mostradas as médias, medianas e os desvios padrões dos domínios da QVV, em função da escola onde o professor trabalha, e o nível descritivo de probabilidade do teste de Kruskal-Wallis, comparando as escolas. 
Tabela 19. Médias, medianas e desvios padrões para os domínios da Qualidade de Vida relacionada à Voz (QVV) e Como você avalia sua voz, em função da escola.

\begin{tabular}{|c|c|c|c|c|c|}
\hline \multirow{2}{*}{\multicolumn{2}{|c|}{ Escolas }} & \multicolumn{3}{|c|}{ Domínios do QVV } & \multirow{2}{*}{$\begin{array}{l}\text { Como você } \\
\text { avalia sua voz }\end{array}$} \\
\hline & & \multicolumn{2}{|c|}{$\begin{array}{c}\text { Sócio-emocionalFuncionamento } \\
\text { Físico }\end{array}$} & \multirow{2}{*}{$\begin{array}{l}\text { Global } \\
78,0\end{array}$} & \\
\hline \multirow{3}{*}{$\begin{array}{c}1 \\
(n=40)\end{array}$} & & 85,5 & 73,0 & & 3,18 \\
\hline & Mediana & 93,8 & 77,1 & 82,5 & 3,00 \\
\hline & D. Padrãd & 19,4 & 19,5 & 18,6 & 0,84 \\
\hline \multirow{3}{*}{$\begin{array}{c}2 \\
(n=32)\end{array}$} & Média & 85,9 & 71,4 & 77,2 & 3,16 \\
\hline & Mediana & 100,0 & 77,1 & 82,5 & 3,00 \\
\hline & D. Padrä & 23,4 & 24,1 & 21,5 & 1,14 \\
\hline \multirow{3}{*}{$\begin{array}{c}3 \\
(n=44)\end{array}$} & Média & 88,9 & 75,1 & 80,6 & 3,45 \\
\hline & Mediana & 96,9 & 79,2 & 85,0 & 3,00 \\
\hline & D. Padrãd & 17,5 & 17,2 & 16,1 & 0,82 \\
\hline \multirow{3}{*}{$\begin{array}{c}4 \\
(n=12)\end{array}$} & Média & 91,1 & 84,4 & 87,1 & 2,91 \\
\hline & Mediana & 100,0 & 85,4 & 90,0 & 3,00 \\
\hline & D. Padrãd & 14,0 & 15,9 & 13,7 & 0,90 \\
\hline \multicolumn{2}{|c|}{ p } & 0,3533 & 0,2708 & 0,3795 & 0,2865 \\
\hline
\end{tabular}

$\mathrm{p}=$ nivel descritivo de probabilidade do teste de Kruskal-Wallis, sendo considerado que existe diferença significativa entre as escolas quando $\mathrm{p} \leq 0,05$.

Embora as maiores médias tenham sido obtidas pela Escola 4 nos três domínios $(91,1$, 84,4 e 87,1 , respectivamente, para os domínios Sócio-emocional, Funcionamento físico e Global), não se evidenciou diferença significativa entre as escolas. Na Figura 4 são ilustradas as médias dos domínios da QVV, em função da escola onde o professor trabalha.

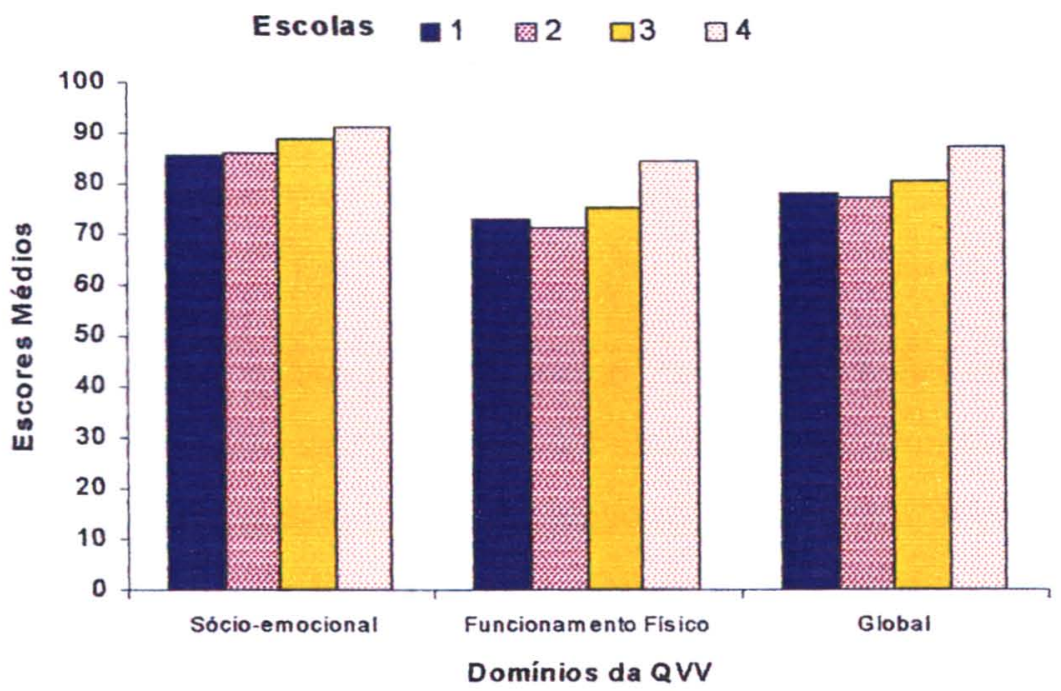

Figura 4. Média dos domínios da QVV em função da escola onde o professor trabalha. 
A observação da Tabela 20, onde é apresentada a comparação dos domínios da QV em função da escola, permite verificar que o teste de Kruskal-Wallis detectou diferenças significativas entre elas somente no domínio Físico $(p=0,0139)$. Assim, nesse domínio, a Escola 1 teve a menor média $(64,8)$, seguida pelas Escolas $3(67,4)$ e Escola $2(70,5)$, nesta ordem, e com a maior média sendo observada na Escola $4(80,1)$. Embora a Escola 1 tenha obtido as menores médias em todos os domínios, não foram observadas diferenças significativas $(p>0,05)$ entre as demais.

Tabela 20. Médias, medianas e desvios padrões para os domínios da Qualidade de Vida (QV) em função da escola.

\begin{tabular}{|c|c|c|c|c|c|}
\hline \multirow{2}{*}{\multicolumn{2}{|c|}{ Escolas }} & \multicolumn{4}{|c|}{ Domínios do QV } \\
\hline & & \multirow{2}{*}{$\begin{aligned} \text { Físico } \\
64,8\end{aligned}$} & \multirow{2}{*}{$\frac{\text { Psicológico }}{66,5}$} & \multirow{2}{*}{$\frac{\text { Relações Sociais }}{67,3}$} & \multirow{2}{*}{$\frac{\text { Meio Ambiente }}{53,9}$} \\
\hline \multirow{3}{*}{$(n=40)$} & Média & & & & \\
\hline & Mediana & 66,1 & 66,7 & 66,7 & 53,1 \\
\hline & D. Padrão & 18,7 & 12,9 & 14,5 & 13,8 \\
\hline \multirow{3}{*}{$\begin{array}{c}2 \\
(n=32)\end{array}$} & Média & 70,5 & 69,3 & 70,3 & 58,3 \\
\hline & Mediana & 71,4 & 70,8 & 75,0 & 57,8 \\
\hline & D. Padrão & 17,2 & 13,1 & 14,3 & 13,1 \\
\hline \multirow{3}{*}{$\begin{array}{c}3 \\
(n=44)\end{array}$} & Média & 67,4 & 67,5 & 71,6 & 56,2 \\
\hline & Mediana & 67,9 & 70,8 & 75,0 & 56,3 \\
\hline & D. Padrão & 11,3 & 10,8 & 11,3 & 12,0 \\
\hline \multirow{3}{*}{$\begin{array}{c}4 \\
(n=12)\end{array}$} & Média & 80,1 & 74,0 & 75,7 & 57,6 \\
\hline & Mediana & 78,6 & 75,0 & 75,0 & 57,8 \\
\hline & D. Padrão & 11,3 & 13,4 & 11,5 & 9,9 \\
\hline \multicolumn{2}{|c|}{$\mathbf{P}$} & 0,0139 & 0,2758 & 0,2835 & 0,5560 \\
\hline
\end{tabular}

$p=$ nivel descritivo de probabilidade do teste de Kruskal-Wallis, sendo considerado que existe diferença significativa entre as escolas quando $\mathrm{p} \leq 0,05$.

Áqui, cabe comentar o fato de os domínios Psicológico e Relações sociais da QV, na Escola 1, apresentarem-se tão próximos aos das outras escolas. Durante o processo de coleta de dados e aplicação dos questionários, a pesquisadora observou diferenças importantes no ambiente sócio/interacional da Escola 1, para pior; o que, no entanto, não se confirmou pela percepção de seus próprios os professores. 
É interessante levarem-se em conta as questões de subjetividade e as diferenças de "olhar" e de "sensibilidade" entre quem tem um contato mais esporádico com a dinâmica escolar (a pesquisadora/observadora) e quem convive diariamente na Escola 1 (os sujeitos/professores). É possível que os professores dessa escola, sem muitas possibilidades de comparação com ambientes sócio-relacionais de outras instituições escolares, acabem por não enxergar ou não identificar alguns daqueles problemas. Mas é possivel, também, que estejamos nos deparando com um movimento defensivo, por parte dos professores da Escola 1 , ao negar os conflitos de relacionamento e o clima pouco afetivo e pouco acolhedor em que convivem.

A Figura 5 ilustra os resultados obtidos na comparação dos domínios da QV em função da escola onde o professor trabalha.

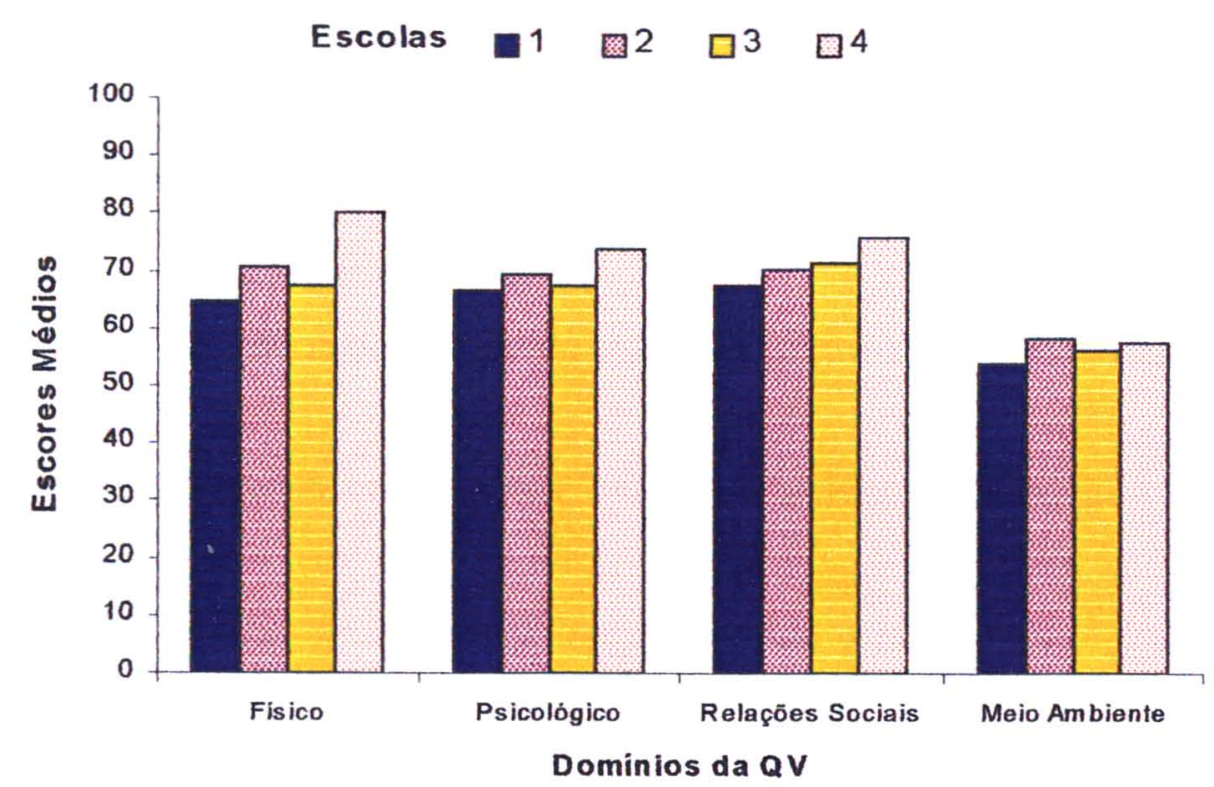

Figura 5. Média dos domínios do WHOQOL/Breve - Qualidade de Vida - em função da escola onde o professor trabalha. 


\section{9 - Faces de "Chernoff"}

$\mathrm{Na}$ Figura 6, são apresentadas as faces construidas para representar os 128 sujeitos envolvidos na pesquisa, considerando os seguintes aspectos: domínios Global da QVV; Físico, Relações Sociais, Psicológico e Meio Ambiente da QV e as questões isoladas "Como avalia a própria voz"; "Como avalia a qualidade de vida" e "Quão satisfeito está com a saúde". Note-se que as características da face associadas a cada domínio e questões são apresentadas na legenda ao lado da Figura, sendo:

Comprimento da boca - quanto mais comprida é a boca, maior foi o escore total obtido pelo sujeito no QVV e, portanto, melhores condições de saúde vocal e menor impacto tem a sua voz na sua vida.

Curvatura da boca - conforme a curvatura volta-se para cima (expressão de sorriso), significa que o sujeito avalia sua voz como muito boa e excelente. Conforme volta-se para baixo significa que avalia sua voz como razoável e ruim. Portanto melhores avaliações com curvas para cima e piores com curvatura para baixo.

Raio da orelha - quanto maior o raio da orelha, o sujeito avaliou como melhor sua qualidade de vida.

Tamanho da face - quanto maior a face, maior é a satisfação do sujeito com a sua saúde.

Comprimento do nariz - quanto mais longo/comprido o nariz, melhores escores o sujeito apresentou no domínio Físico do QV, ao qual correspondem as questões $3,4,10,15$, 16,17 e 18 .

Largura do nariz - quanto mais largo o nariz, melhores escores o sujeito obteve no domínio Meio ambiente do QV, ao qual correspondem as questões 8, 9b, 12, 13, 14, 23, 24 e 25.

Comprimento do olho - quanto maior e mais comprido for o olho, melhores escores o sujeito obteve no domínio Relações sociais do QV, o qual corresponde às respostas das questões 20b, 21 e 22.

Sobrancelhas - quanto maior a inclinação da sobrancelha em direção ao canto distal dos olhos, piores escores o sujeito obteve no domínio Psicológico do $\mathrm{QV}$, que corresponde às respostas dadas às questões $5,6,7,11,19$ e 26. 
A observação da Figura 6 permite verificar os dados dos domínios e questões da QVV e da QV de cada sujeito e no conjunto. Deste modo, anotem-se alguns exemplos:

- 0 sujeito 1 apresentou resultados ruins para todos os domínios e questões, exceto para o domínio Relações Sociais do QV, representado pelo comprimento do olho;

- 0 sujeito 2 mostrou resultados bons, exceto pela auto-avaliação da voz, por ele considerada como "razoável";

- O sujeito 3 apresentou resultados intermediários na maioria dos aspectos considerados;

- $O$ sujeito 7 mostrou resultados bons para os aspectos considerados;

- Os sujeitos $1,3,5,31,36,37,38,41,45,46,48,51,55,67,70,71,79,91,104,105$, $106,110,111,112,114,116$ e 123, podem ser apontados como os(as) professores(as) com os menores escores no domínio Global da QVV.

A partir das Faces de "Chernoff", foram selecionados os(as) professores(as) que participariam da segunda fase dessa pesquisa. Foram selecionados aqueles que apresentavam escores mais baixos no QVV - nas Faces de "Chernoff", os que apresentavam menor tamanho de boca. Assim, selecionaram-se 27 sujeitos dentre os quais se sortearam os 12 sujeitos que comporiam o grupo focal.

O grupo focal ficou, então, constituído pelos sujeitos: $31,41,45,48,70,79,91,106$, $112,114,116$ e 123. Desses, nove são mulheres e três homens (sujeitos 70,91 e 114). 
Figura 6. Faces de "Chernoff" - Representação dos resultados para cada um dos 128 sujeitos envolvidos na pesquisa, conforme a legenda.

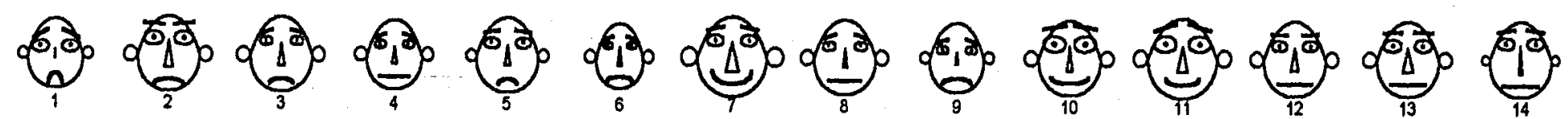
(4)

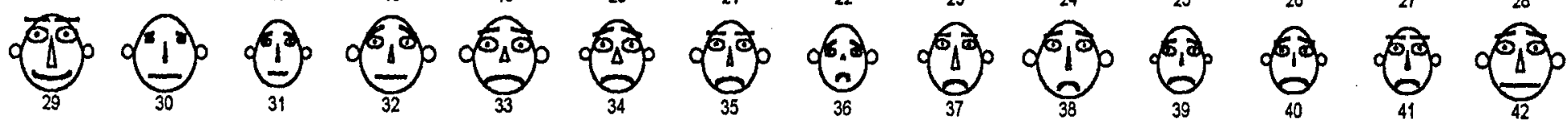

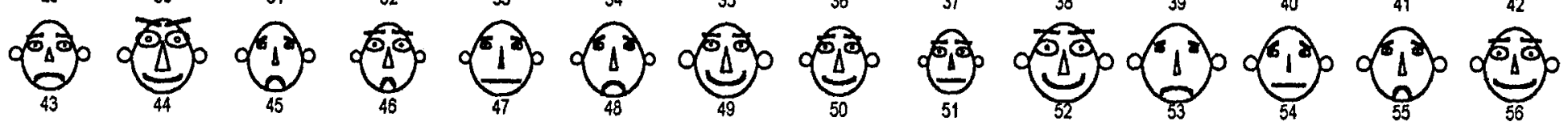

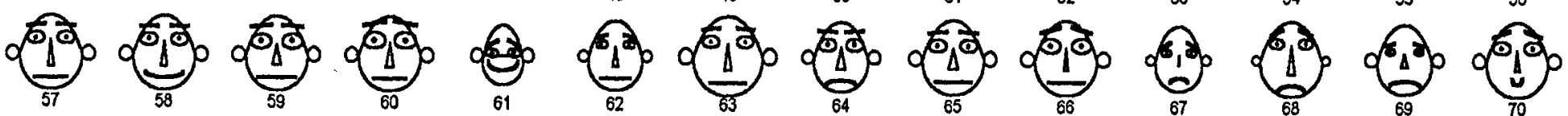

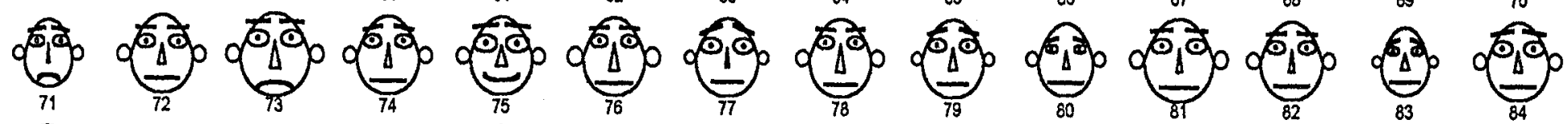

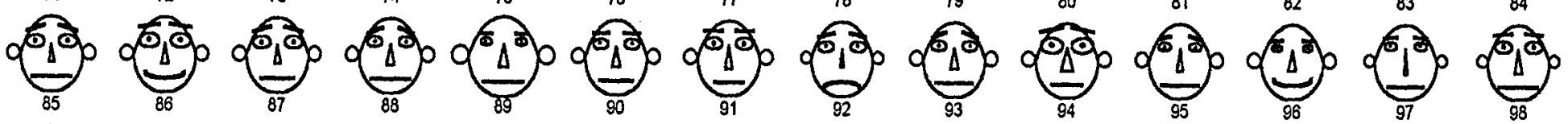

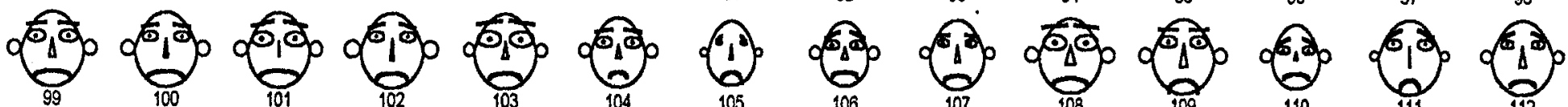

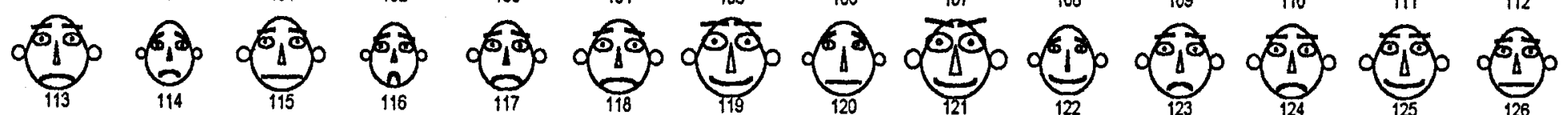
(4)

\section{LEGENDA:}

Comprimento da boca: QWV-Dominio Global;

\section{Curvatura da boca:} Como avalia a voz;

\section{Raio da orelha:}

Como avalia a Qualidade de vida;

Largura e altura da face:

Quão satisfeito está com a saúde;

Comprimento do nariz: Q.V. - Dominio Físico;

Comprimento do olho: Q.V. - Dominio Relaçð̃es Sociais;

Sobrancelha:

Q.V. - Domínio Psicológico;

Largura do nariz:

Q.V.- Dominio Meio Ambiente. 


\section{RESULTADOS DA SEGUNDA FASE DA PESQUISA}

Os resultados da segunda fase da pesquisa - os dados do grupo focal - são agora apresentados a partir das categorias, temas e conjuntos temáticos que emergiram a partir da análise de conteúdo, quais sejam:

\section{1 - ORGANIZAÇÃO DO TRABALHO DOCENTE}

1.1.- As relações sociais no trabalho

1.1.1 - Relações sociais professor-alunos

1.1.1.1 Afetos e conflitos na relação com os alunos

1.1.1.2 Relações de contigüidade profissional/função matema-paterna; escola/lar e comunidade escolar/família do professor

1.1.2. - Relações sociais docente - administração/coordenação

1.2. - O processo ensino-aprendizagem

1.3 - Trabalho docente e constituição da subjetividade

2 - ORGANIZAÇÃO DA VIDA PRIVAdA (PESSOAL, FAMILIAR E SOCIAL)

2.1 - Implicações do trabalho na família

2.2 - Implicações do trabalho no lazer

\section{3- USOS DA VOZ NOS CONTEXTOS COTIDIANOS}

3.1 - Usos da voz no trabalho docente

3.2 - Usos da voz na vida privada

\section{4 - PROCESSO SAÚdE/DOENÇA DO TRABALHADOR PROFESSOR}

4.1 - Implicações do trabalho docente no corpo e processo saúde/doença do trabalhador professor.

4.2 - Noções de higiene vocal/saúde vocal

4.3 - Preocupações e representações referentes ao processo saúde-doença vocal

4.4 - Percepção e identificação de um problema de voz/saúde vocal

4.5 - Estratégias de "enfrentamento" dos problemas de voz/saúde vocal 


\section{1 - ORGANIZAÇÃO DO TRABALHO DOCENTE}

A análise e discussão buscam contemplar, na medida do possível, os aspectos que sinalizam o trabalho prescrito e o trabalho real, com as diferenças ou os distanciamentos entre eles e, também, os aspectos de adesão e de resistência ao trabalho docente.

\section{1. - As relações sociais no trabalho}

Nesse eixo temático, as categorias que emergiram foram referentes às relações sociais com alunos e com o corpo administrativo da escola - Direção e Coordenação. As relações sociais com familiares dos alunos, demais funcionários da escola e a comunidade que configura o entorno escolar não foram mencionados pelos professores participantes do grupo focal.

\subsection{1 - Relação professor-alunos}

\subsubsection{1 - Afetos e conflitos na relação com os alunos}

A relação afetiva é importante. A gente tem que ter uma boa relação com os alunos (S1 16)... Onosso trabalho está ligado ao emocional; não é apenas o conhecimento; o nosso trabalho não é apenas uma transmissão de conteúdos; é a relação afetiva como aluno. Eu sou professor há cinco anos e ai eu fico pensando comigo mesmo: esse trabalho é tão importante, né? (...) Até em termos de sociedade, porque nós trabalhamos não apenas com a informação, mas com a formação do ser humano, né? (S91)...

$O$ defeito é ter um contato maior aluno/professor; lá na escola há um contato muito grande; tem aluno que fica de manhã, tarde e noite na escola, fica na biblioteca, fica lá o dia inteiro (S70)... Eu quero bem, mas, tem que aprender (S116)... Eu falo para eles "meu maior defeito é que eu gosto de vocês!" Eles falam "ah, professora, porque? Você não queria gostar?" eu falo "ah, seria mais fácill" Seria mais fácil; "é mais fácil falar sim para vocês do que ficar falando não!, não!, não! É muito mais fácil largar vocês no corredor, muito mais fácil largar vocês fazendo o que vocês querem"; muito mais fácil, né? Meu maior defeito é gostar demais, é gostar deles. Por isso, por nós gostarmos deles, dos piores alunos, daqueles terrores, daqueles capetas! - e são os que ficam mais grudados em você! - a gente sofre (S41)... Isso causa sofrimento! As vezes a gente sabe dos problemas de familia deles, e isso causa uma angústia! Às vezes o pai está preso, a mãe está presa, a mãe foi assassinada e a gente sofre junto - "ai, coitadinho!" (S112)... No terceiro ano do Ensino Médio, aqueles que foram nossos alunos, eles não vão embora, eles ficam ali: "professora, posso assistir um pouco sua aula?" eu falo "vai fazer alguma coisa" e eles "não, eu vou ficar aqui" e entram na sala de aula e ficam lá (S41)... E, o terceiro ano, terminou, você pensa que vai embora, né? Mas, não! Assim que eles podem eles aparecem na escola para visitar a escola e, se possivel, ainda assistir um pouquinho a sua aula - só que quando estavam na escola davam trabalho! (S45)... Então é assim, eles ficam realmente muito 
ligados na gente. $\dot{E}$ a coisa mais comum lá, sabe? Um pega seu caderno, outro pega aqui, outro abraça, eles são assim (S41)... Eles vivem pendurado no pescoço, né? (S116)...

Uma coisa que eu não gosto, que me irrita, é eu querer explicar e alguém olhando do lado ou alguém conversando (S70)... Ás vezes eu fico lá (...) com aquela classe cheia, aquele monte de aluno falando alto e eu não consigo atingir os alunos (S48)... Outro método meu lá no serviço é pegar um livro grosso e socar na mesa (faz o gesto) e "POU!", faz aquele barulhão! Os alunos pulam dessa altura (estica o braço à sua frente) da cadeira; e at eles prestam atenção (S70)... Eu soco o livro na cabeça do aluno - e ele sabe (olha para o câmera-man) porque ele foi meu aluno, ele sabe que eu puxo o cabelo, né? (S1 16)... Eles só reagem perante a uma ameaça, né? Se você não ameaça, não vai. Se eu falo para eles "quatro pontos a menos na média!", at acaba! (S48)... A gente percebe que tem que tomar atitudes que se a gente parar pra pensar não teria que chegar a esse ponto, de ter que buscar artificios para você se comunicarl (S91)... Você sabe que para mim só o fato de ter que fazer isso, de que eu ter que ficar berrando pra eles quererem, poderem prestar atençäo na minha aula, já é um fator de inibição, eu já perco a voz, sabe? O fato de você ter que forçar uma aluna a prestar atenção na sua aula... Pôxa, você vai lá para isso! (...) ter que implorar para assistir minhas aulas, uma coisa que vai beneficiar eles e que vai fazer eles crescerem? (S112)...

A dimensão afetiva do trabalho docente é reconhecida pelos professores como um fator de valoração do próprio trabalho e, especialmente, quando os sentimentos de afeto, atenção e carinho se fazem presentes na relação interpessoal professor-alunos. Essa experiência positiva da afetividade configura-se como um dos aspectos que contribuem para a adesão ao trabalho docente, confirmando as assertivas de PEREIRA e ENGELMANN (1993).

Entretanto, a afetividade exerce um papel dúbio para a adesão e para a resistência, pois a afetividade decorrente da aproximação e do envolvimento professor-aluno é conflitante com a necessidade de estabelecer limites, de imposição e cumprimento das normas e regras institucionais inerentes à organização do trabalho docente, o que leva o professor a assumir posicionamentos mais firmes e até com certo grau de distanciamento do aluno. $O$ envolvimento maior com o discente também propicia ao professor tomar conhecimento de aspectos de sua vida privada e, ao compartilhar daqueles problemas o professor angustia-se e sofre.

Evidenciam-se, aqui, os conflitos entre vivenciar ou não a afetividade com os alunos: se por um lado a afetividade se faz fundamental nas relações sociais no trabalho docente, e o professor deseja ter esse bom relacionamento com o aluno, por outro lado, da maneira como ela é compreendida, torna-se incompatível com a dinâmica de organização do trabalho docente que, na prática, envolve posturas autoritárias e controladoras. Conforme CODO e 
VASQUES-MENEZES (2000-b), desses descompassos entre a vinculação idealizada e o tipo de vinculação possível de ser estabelecida resultam tensões, conflitos e dúvidas entre vincular-se ou não afetivamente com seus alunos, podendo, dessa forma, conforme CODO e GAZZOTTI (2000), instaurar-se um quadro de sofrimento que repercute negativamente na relação do professor com o trabalho e na sua vida pessoal, por vezes levando-o a pensar em desistir da docência.

O professor tem a expectativa de que a relação pedagógica se desenvolva num contexto afetivo e intersubjetivo positivo e favorável, o que pressupõe, nos termos de MORGADO (1995), somente a transferência positiva de sentimentos ternos de afeição e respeito, por parte do aluno, que estaria disposto a colaborar com o professor e com a concretização dos objetivos educacionais.

Entretanto, a realidade cotidiana das relações sociais professor-alunos apresenta-se de maneira muito diferente, senão vejamos: na situação real, o professor não tem a atenção dos alunos sobre si, pois os olhares e o diálogo dos alunos ocorrem entre eles próprios, e o centro da atenção dos alunos em sala de aula não é o professor nem o são os conteúdos curriculares por ele abordados. A comunicação e a interação do professor com os alunos não é um fato natural, mas sim resultado de lutas, esforços e investimentos intensivos e constantes dos profissionais que, perante a necessidade de serem ouvidos, de chamarem a atenção dos alunos e de controlarem a conversa, agitação e disciplina em sala de aula, desesperam-se e se desgastam, assumindo posturas e atitudes autoritárias, controladoras, ameaçadoras, agressivas e violentas, valendo-se de recursos e artificios dos mais variados - dentre os quais o recurso vocal - lembrando que essas posturas assumidas no trabalho real são contraditórias àquelas idealizadas pelo professor em seu trabalho.

Tais dificuldades de comunicação e de relacionamento que o professor enfrenta com os seus alunos configuram-se, também, como fatores causadores do estresse docente, conforme STACCIARINI e TRÓCCOLI (2002); e, segundo MARTZ (1999), repercutem nas questões de voz e na saúde vocal do professor. 


\subsubsection{2 - Relações de contigüidade profissional/função materna-paterna;}

escola/lar e comunidade escolar/família do professor

Outro dia um aluno chegou e falou "ô pail"; sabe, ele me confundiu com o pai dele: "ô pai!"Porque ele quer uma pessoa, um pai - que talvez seja ausente ou então se assemelha (...) Eu até chamo, eu falo assim "ó, tem que parar de fumar, heim! (balança o dedo em riste) tá fumando muito!" Eu falo "tá fumando maconha ai, ó!" Eles não me levam a mal, não ficam ofendidos, se eu falar alguma coisa assim eles não ficam ofendidos, porque é uma relação de amizade (S70)... Às vezes eu faço umas viagens com alunos, por causa da minha disciplina (ciências e biologia) e fui para a praia esses dias com uns alunos. Então, às vezes, eu me envolvo tanto com eles que eles me chamam de mãe, de tia, de vó (pausa) mais ai eu fico brava, né? Avó já é demais! (S116)...

A escola é a continuação da casa do aluno e a do professor também, né? Porque eu acho que é a mesma coisa; ali é uma outra familia, é uma outra casa, você e seus alunos, suas amizades (S48)... As vezes, eu entro na sala de aula e falo "pelo amor de Deus! arrumem essas carteiras! peguem esse papel e joguem no lixo"! Dat eles limpam. Eu falo para eles "na casa de vocês, vocês jogam no chão?" - "Não!" - "Então porque joga aqui?"; então a gente associa mesmo, porque eles passam um tempão na escola (S41)...

As relações de contigüidade entre escola-casa e comunidade escolar/família do professor são percebidas no jogo de transferências e identificações entre as figuras do professor e as figuras de autoridade paterna-materna dos alunos (KUPFER, 1982 e MORGADO, 1995), por isso, envolvidos pela afetividade inerente ao trabalho docente, os professores acabam correspondendo ao jogo de transferências dos alunos, assumindo as representações paternas/maternas, na contra-transferência, fato que resulta, por exemplo, em atitudes como ordenação e repreensão dos alunos que fumam ou exigindo a organização e limpeza do mobiliário da sala de aula, como se fossem seus pais ou se estivessem cuidando da organização de suas casas.

Percebe-se, ainda, a recorrência das dificuldades de professores e professoras em caracterizar seu papel, função social e identidade profissional no campo do trabalho e no âmbito da profissão de mestre, uma vez que continuam vendo, na escola, a extensão da própria casa, do próprio lar e, nos alunos, a extensão da própria família, numa relação de parentesco que foi fundada a partir das questões de gênero que influenciaram e que determinaram os modos de ser do trabalhador docente (especialmente da mulher professora), no final do século XIX e início do século XX (NOVAES, 1995; ASSUNÇÃO, 1996; LOURO, 1997 e NEVES e ATHAYDE, 1998). Essas questões ainda se fazem presentes na realidade do 
trabalho docente atual, e indicam aspectos merecedores de discussão e de reflexão na busca da constituição da subjetividade, da identidade e dos modos de ser do professor.

\subsection{2 - A relação docente/administração-coordenação}

Eu tive em outra cidade uma direção assim que chega e fala "o que nós vamos fazer?" Isso é muito diferente! (S123)... Uma das nossas coordenadoras faz uma HTPC super agradável, é uma lady para conversar, ela fala baixinho, ela é delicada, é muito educada, então ela dá uma ordem para nós é é como se fosse uma troca de favores, uma coisinha corriqueira (S41)... Lá na outra escola eu era nova, de outra cidade, mas tudo o que ia fazer na escola eles vinham pedir minha opinião: "Você vai fazer aquele curso, vai fazer aquele outro? " Eu me sentia valorizada, eu trabalhava melhor (S79)...

Na escola (ininteligivel) o que eu tenho que fazer é recolher aluno para a sala de aula e ficar lá dentro. E não falte! E não falte! (S79)... São ordens que vêm de cima, de fazer coisas que a gente acha que não tem sentido a gente fazer, tipo ficha de aluno individual, renovar falta de aluno - que é serviço da secretaria - então é complicado! (S1 16)... Eu não sinto valor nenhum, e o discurso é outro. Eu tenho pavor! Eu tenho ódio (coloca as duas mãos na cabeça e muda a voz, falando em tom de ironia) dessa frase: "vocês são a melhor equipe da cidade"! Gente, eu tenho pavor dessa frase! Porque a gente é tratada como se fosse a pior! (S79)... Me incomoda porque é falsidade! Me incomoda muito! Me irrita, porque eu estou sendo chamada de boba, sabe? Eu me sinto assim, sendo chamada de boba! (S123)... É uma tática! Você sabe que é só discurso, que é uma tática! (SI12)... Falta um pouco de calor humano (S79)... Na nossa escola tem muito autoritarismo, isso pelo o que eu sinto, sabe? Então: "é isśo que tem que fazer!"; não tem "o que você acha?"; é "é assim e acabou!" (S112)... Não te escutam (S79)... A coordenadora chega e fica assim (balança o indicador em riste repetidamente); assim não dá né? (S41-sorri)...

Tem hora que eles (direção e coordenação) tratam a gente como se fôssemos um bando de alunos, de moleques, irresponsáveis! E eu não gosto disso, porque eu não sou irresponsável. Mas a gente é tratado assim e isso pára aqui ó! (aponta a garganta) Pára aqui, tá? Então não tem conversa, não tem diálogo! (...) Você ouve um "não" antes de você terminar de falar; eu não sinto valor nenhum (S79)... Não respeitam o nosso trabalho (S112)... Parece que é educado, mas ao mesmo tempo, por baixo, é tudo mandado (S91)...

Nosso sistema é muito rigido; o aluno não pode ficar fora de sala de aula, se você deixa ir tomar água o diretor fica bravo! (S116)... Os alunos comentam que a direção os trata mal; não os ouve e eles querem ser ouvidos (S106)... O coordenador pedagógico da escola... tá filmando, né? (olha para a câmara) tem aluno que tem ódio mortal dele. Isso é tão nítido que as vezes, ele está passando no corredor, os alunos correm (S91)... Lá é a pedagogia do medo, sabe? (S112)...

Enquanto trabalho prescrito, o professor espera ser tratado pela Direção e pela Coordenação Pedagógica com cordialidade, delicadeza, consideração e respeito. O professor espera participar das decisões administrativas que dizem respeito ao seu trabalho e suas idéias serem ouvidas e consideradas; o que estaria em conformidade com o que sugere COELHO (1998), na perspectiva da responsabilidade coletiva, com valorização dos 
educadores e demais sujeitos envolvidos no processo de ensino. Quando o professor percebe que pode opinar e ser ouvido e considerado, sente-se valorizado como pessoa e trabalhador; e isso é importante na representação que o trabalho assume para ele, contribuindo para uma maior adesão à atividade docente e repercutindo na melhoria da qualidade do trabalho realizado. Também configuraria o apoio social e senso de coesão de grupo que, em conformidade com autores como HELMAN (1994) e SORATTO e RAMOS (2000), seriam fatores de proteção profissional que ajudariam o professor a suportar e melhor enfrentar as agruras do trabalho e os problemas cotidianos.

Entretanto, na relação social entre docente e administração-coordenação real que ocorre no cotidiano escolar, o que se observa é que as expectativas dos professores, anteriormente apontadas, não são correspondidas e, na maioria das vezes, o professor sente-se excluído de um processo decisório e tem sua função tutoriada, controlada e reduzida a cumprimento de normas burocráticas e técnicas. A rigidez da estrutura escolar e a falta de controle dos professores sobre as decisões escolares são fatores considerados pela O.I.T. (1981 e 1991) como causadores do estresse docente. Autores como PEREIRA e ENGELMANN (1993), em sua pesquisa com professores universitários, apontaram o excesso de burocracia e a falta de envolvimento acadêmico-institucional como aspectos expressivos da experiência emocional negativa no trabalho docente.

Há um complexo movimento de interações, de significações, de afetividades, de lutas, de conflitos, de interesses e de poderes nessas relações que, conforme CUNHA (1999), interferem na subjetividade docente e no ato educativo. Os professores se ressentem da representação que o corpo administrativo possui deles, a ponto de que nem mesmo os eventuais elogios que recebem se sobrepõem ao tratamento depreciativo a que estão habituados por parte dos seus superiores hierárquicos, na escola. Nessas situações, os discursos elogiosos entram em choque com a forma de tratamento recebido e, desse desencontro valorativo, resulta a sensação negativa de estarem sendo enganados ou questionados em sua inteligência e capacidade de percepção da contradição ali engendrada. Dessa forma os professores sentem-se duplamente atingidos: como pessoas e como profissionais. 
A hierarquia escolar explicita o exercício do poder e de relações autoritárias, controladoras, disciplinadoras e reguladoras do tempo, das vontades, das idéias, das ações e atividades produtivas do trabalhador professor, confirmando o que afirmam autores como FOULCAULT (1995), LOURO (1997) e NAKAMURA (2001); e isso tudo incomoda os professores, que se irritam e sentem-se ofendidos, desconsiderados, desacreditados e desrespeitados pelos seus superiores hierárquicos, num processo que atinge diretamente sua subjetividade.

Esses resultados mostram que a realidade dessas escolas encontra-se muito distante daquela desejável quando se trata de pensar na perspectiva de formação de Escolas Promotoras de Saúde - em que seria esperado uma comunidade escolar preocupada com o bem estar de todos e promotora de relacionamentos cordiais e respeitosos entre os seus profissionais (SILVEIRA, 2000).

Os professores demonstram que têm poucas oportunidades de reflexão e de discussão sobre a qualidade das relações sociais que estabelecem com seus superiores administrativos e que apresentam dificuldades em expressar os sentimentos e impressões a esse respeito. Isso pôde ser evidenciado nas considerações sobre a interanimação dialógica (apresentadas ao final deste capítulo) e, também aqui, na medida em que os professores se valem das opiniões de alunos para expressarem suas próprias impressões, opiniões e sentimentos acerca da direçãocoordenação, numa demonstração do quanto thes é dificil falar, por si mesmos, o que pensam e o que sentem das relações sociais hierárquicas que envolvem a administração escolar.

As relações sociais hierárquicas na escola são merecedoras de atenção e de investimento nas propostas mais amplas de promoção da saúde e qualidade de vida no ambiente escolar uma vez que, conforme CODO e VASQUES-MENEZES (2000-a), importa considerar as questões da violência explícita ou velada do poder, da norma, das regras, do controle, das hierarquias institucionais e dos desafetos que atingem a identidade e a vida do professor.

Assim, confirma-se, também na relação docente/administração-coordenação pedagógica, a oposição valorativa do trabalho docente e do próprio professor, já que uma 
relação social hierárquica idealizada é contrastante e diverge das reais condições em que se desenvolve no cotidiano do trabalho docente, predispondo o professor a sentimentos negativos e a sofrimentos que acabam contribuindo para o estresse e a resistência ao seu trabalho (BETANCOURT e PALACIOS, 1999; FONTANA, 2000; COLBARI, 2001; HECKERT et al., 2001; ROCHA e GLIMA, 2002 e STACCIARINI e TRÓCCOLI, 2002).

Todos esses aspectos sugerem a necessidade de investimentos para a melhoria da qualidade da comunicação e das relações sociais hierárquicas na escola, da flexibilixação dessas relações e, também, das formas de expressão e de comunicação das representações nelas constituídas. Apontam, também, a importância de se considerarem os aspectos que interferem na valorização e constituição da subjetividade e identidade do trabalhador.

Na medida em que o fonoaudiólogo possa contar com uma sólida formação para atuar com grupos, a proposta grupal configura-se como recurso importante para propiciar a percepção e discussão das formas de relacionamento, interação e comunicação - que se constroem no processo grupal - e para oferecer possibilidades de flexibilização de papéis e desenvolvimento das relações sociais.

\section{2.- O processo ensino-aprendizagem}

O ponto principal da aula é o professor estar ali explicando, estar falando (...) Tem que atingir todos os alunos, eu acho que é um ponto muito negativo você não conseguir isso (S48)... O professor tem que ser calmo, conhecer a matéria que está dando, fazer devagar (S70)...

O professor não teria que explicar tudo, teria que ser requisitado a explicar, entendeu? (...) o professor seria um instrumento de esclarecimento para o aluno e não estar dando tudo pronto. Isso deveria ser, mas não é. Não él (...) Então o professor seria um facilitador. Só que nós não somos isso! Não conseguimos ser isso até hoje (...) nós deveriamos falar o que eles pedissem, o que eles precisassem da gente e não dar para eles assim, meio que gratuitamente, sem que eles estejam querendo ou precisando! A gente tinha que ser requisitado e não se oferecer a eles (S116)... O aluno deveria estar estudando e estar perguntando para o professor (S116)... Quando eles perguntam, ai é que você atinge, porque eles levantaram o problema, por isso que eu digo, de novo, a necessidade do aluno fazer a sua leitura e ele perceber as suas dificuldades é fundamental para que você consiga atingi-los (S106)...

A gente joga tudo pronto em cima do aluno e o aluno faz de conta que ouviu (S116)... Infelizmente, nós estamos nos oferecendo; foi o único jeito que nós encontramos até agora (S116)... O trabalho 
fica muito prejudicado na medida que os alunos não conseguem se virar sozinhos. Eos alunos não estão preparados para trabalharem sozinhos, infelizmente. Eles estão cada vez mais dependentes da gente, se você colocar lá um trabalho pra eles fazerem sozinhos é um fiasco, eles não conseguem nem se concentrar, nem fazer. Então o professor tem que estar orientando sempre; é fundamental estar orientando! (S116)... A impressão que dá é que eles querem ser pageados (S112)... A turma não aceita participar de uma forma dinâmica, a turma quer aula expositiva! (S1 16)... A nossa situação hoje está assim, sendo mais exigida nossa presença, justamente por causa desse comodismo do aluno: ele não lê, ele não pára pra pensar, ele já vai direto no "não entendt!"; $e$ você acaba fazendo um papel até que não deveria (S106)... Tem um bando de alunos acomodados, porque no momento que eu expliquei eles estavam lá, não prestaram atenção, olham para baixo, do lado, não fez, e depois "você é obrigado a explicar para mim novamente" (S70)... Na verdade o aluno fala que não entendeu porque não leu e também porque não quer lerl Porque, se ele entender, ele não vai ter a sua atenção! (...) Mas, se o aluno fala que entendeu tudo, não tem porque falar, ter esse afeto, esse emocional, ele está querendo é o carinho e muitas vezes nós não percebemos (\$45)...

Há representações de processo ensino-aprendizagem que correspondem, simultaneamente, a dois modelos distintos: democráticos-participativos e centralizadorestradicionais, sugerindo que o professor ainda tem dúvidas em definir um ideário para o seu papel e para o processo de ensino por ele instaurado.

Há um aluno idealizado e um papel idealizado de professor, numa relação idealizada que ora se fundamenta em concepções de educação e processo ensino-aprendizagem tradicionais e autoritárias e ora propende a características democráticas e participativas.

Por um lado, o professor espera desenvolver um processo ensino-aprendizagem democrático, em que o aluno seja interessado, seja atuante e participante ativo, coresponsável, compromissado com a busca do conhecimento e a construção da aprendizagem (FURLANI, 2000). O papel reservado ao professor, aqui, é o de facilitador e esclarecedor das dúvidas e questões colocadas pelos alunos, numa expectativa que pressupõe, por parte do aluno, a existência do desejo e do sentido direcionados ao saber e ao conhecimento - algo que muitas vezes não se dá a priori, mas resulta de uma construção conjunta na relação professoraluno (MORGADO, 1995).

Por outro lado, concorrem outras idealizações, do papel do professor e da relação pedagógica, às quais correspondem posturas centralizadoras, controladoras e autoritárias, que se aproximam das tradicionais aulas expositivas, em que o professor se coloca no centro do processo ensino-aprendizagem, conferindo-se o poder e a autoridade, numa dinâmica de aula 
em que assume para si a função ativa de falar e de explicar na expectativa de, através da fala, atingir todos os alunos, obtendo deles a atenção constante. Tais idealizações não escondem os desejos e as necessidades do professor, na busca e conquista do poder, da autoridade e de satisfações narcíseas (KUPFER, 1982 e MORGADO, 1995).

$O$ fato de o professor colocar-se no centro do processo ensino-aprendizagem aponta uma propensão à dominação verbal que cria o silêncio do aluno, com conseqüente predomínio da demanda vocal docente (FREIRE e SCHOR, 1990). Além disso, ao desejar a atenção e atingir a todos os seus alunos da mesma maneira, o professor demonstra que desconsidera a subjetividade e as diferenças de experiências e de interesses daqueles, as quais resultariam em nuanças do que se considera atingir cada um deles. Confirma-se, então, a percepção de GUZZONI (1995), de que a escola ainda não consegue lidar com a heterogeneidade.

Diferentemente das idealizações, o aluno real é tido como incapaz, acomodado, dependente, desinteressado e sem iniciativa. O professor,então, passa a ocupar o centro do processo ensino-aprendizagem e, buscando "compensar" a falta de participação ativa dos alunos, redobra a sua própria dedicação e responsabilidade. No entanto, ao assumir atitude paternal-maternalista, reafirma a relação de dependência dos mesmos dificultando a superação da transferência inicial de autoridade e poder; confirmam a assimetria professor-aluno, ao mesmo tempo em que impedem a superação dessa assimetria, num processo que pouco contribui para a reversibilidade de papéis e de posicionamentos, para a autonomia, emancipação intelectual e processo de constituição da subjetividade do aluno (KUPFER, 1982; GUZZONI, 1995; MORGADO, 1995 e ORLANDI, 1996).

Enfim, no trabalho real o professor acaba por empregar o roteiro de aula tradicional e as relações autoritárias e ameaçadoras, que exigem de si próprio que fale alto e que fale muito, quase gritando, num processo de dominação verbal que visa superar as resistências dos alunos, requerendo intensa demanda vocal (FREIRE e SCHOR, 1990 e FURLANI, 2000).

Os professores não demonstraram considerar a subjetividade, a heterogeneidade, as diferenças, o jogo e dinâmica de transferências, os movimentos dos elementos de autoridade e de poder, nem a existência de conflitos na relação intersubjetiva professor-alunos. Esse 
contexto idealizado entra em choque com as reais condições dos sujeitos, das relações que eles constituem e da realidade cotidiana do trabalho docente, predispondo o trabalhador professor a sentimentos negativos e a sofrimentos decorrentes da impossibilidade de realizar seu trabalho tal como é idealizado ou prescrito (BETANCOURT e PALACIOS, 1999; FONTANA, 2000; COLBARI, 2001 e ROCHA e GLIMA, 2002).

Os embates e as diferenças entre o trabalho prescrito e o real são visíveis; nos conflitos que sinalizam essas diferenças encontram-se as fontes de estresse, frustração e sofrimento do professor, no contexto da organização do trabalho docente.

Essas diferenças também podem impedir a constituição de relações condizentes com a proposta de formação de Escolas Promotoras de Saúde; na qual seria desejável a participação ativa do alunado e da comunidade junto ao projeto pedagógico e ações desenvolvidas na escola (SILVEIRA, 2000). É preciso instaurar processos que ajudem o professor a "encontrarse" com seu aluno real e que subsidiem a reflexão, discussão e re-significação dos referenciais teóricos e das concepções que sustentam e que orientam o papel docente e o processo ensinoaprendizagem, de maneira a tornarem-se mais ajustados, condizentes e aplicáveis à sua realidade e à concretização da proposta de Escola Promotora de Saúde.

\section{3 - Trabalho docente e constituição da subjetividade}

Quando eu comecei a dar aula eu era bem mais tímida, tinha menos segurança, né? Então a minha voz não saía assim, eu falava bem mais baixo e ninguém escutava mesmo (...) então quando você vai ficando mais madura, vai tendo mais segurança, a sua voz vai saindo mais alto, sabe? (S112)... Sabe, eu sou uma pessoa que eu não consigo ficar sem falar (...) e quando eu não falo (mexe com as mãos representando ansiedade); então eu falo, de um jeito ou de outro! (\$45)... É importante para a gente se sentir útil também, né? Então eu estou falando mas estou conseguindo resultado do que eu estou falando (S116)... Os alunos foram evoluindo (...) todos tiraram nota boa, então eu fiquei: "olha! Nossa, que felicidade!" (abre um sorriso e aproxima as duas mãos ao peito) "Como eu sou bom!" (risos - todos riem). Al foi até muito engraçado, eu falei isso na quarta-feira, comentei isso com a minha esposa "olha só, essa classe não tirou uma nota vermelha!" (...) Num momento elevou a autoestima lá em cima (S70 - levanta o braço indicando altura)... Mas ai chegou na sexta-feira e caiu a cara! (solta os braços sobre as pernas, inclina o corpo para frente, abaixa a cabeça e demonstra expressão facial triste - e depois sorri) "Eu sou ruim de novo!" Um monte de notas nuins. "Ah não! Eu não acredito!" E ai vou xingando eles: "olha isso, que absurdo!" (gesticula com as mãos como se estivesse corrigindo as provas) "que absurdo!" (...) "Ah, não!" Caiu a cara! (S70)... Aquela direção 
que (balançando o dedo indicador em riste) "ó, nós temos que fazer issol” incomoda muito a gente, porque a gente não quer ser tratado como um bando de irresponsáveis! Isso me incomoda sim! Me irrita e me deixa muitas vezes angustiada e com vontade de desistir da profissão. Porque, que raio de profissão é essa que nós somos o elemento principal e somos tratados infantilmente? (S123)... Esse trabalho é tão importante e eu fico pensando até que ponto a gente está conseguindo ter uma satisfação com o trabalho, porque muitos de nós não nos sentimos realizados, né? Alguns já mudaram de profissão, outros não sabem se querem fazer outra coisa, outros ficam na expectativa de esperar que a coisa vá melhorar"; uns professores já perguntaram para mim "ah, porque você não arruma outra coisa para fazer?". As vezes a gente passa, a maioria do tempo, mais frustrado do que realizado (S91).

$\mathrm{Na}$ dinâmica do trabalho docente, as relações interpessoais professor-alunos propiciam a constituição da identidade, da subjetividade e do modo de ser moral enquanto pessoa e docente: trabalhando, o professor observa o seu desenvolvimento e amadurecimento pessoal; identifica as suas características pessoais e a elas atribui sentido e utilidade; ora eleva sua auto-estima e auto-imagem como pessoa e trabalhador e ora as percebe reduzidas; e essa dinâmica pode tanto desencadear vivências e sentimentos de prazer como de sofrimento, relacionados ao trabalho e à própria pessoa (ROSA, 1991 e 1994; SORATTO e OLIVIERHECKLER, 2000-b; VASQUES-MENEZES e GAZZOTTI, 2000).

Oṣ resultados demonstram que o professor vem sofrendo em função da percepção negativa que possui acerca da representação que o corpo administrativo teria dele e do seu trabalho. Isso contribui para a redução da sua auto-estima, ao mesmo tempo em que confirma as assertivas de FONTANA (2000), de que as relações de ensino não nascem nem se esgotam nos limites da sala de aula ou nos limites da interação professor-aluno e que as relações sociais e condições de organização do trabalho docente têm repercussões diretas na constituição da subjetividade como pessoa e trabalhador - com implicações na voz/saúde vocal. 


\section{2 - ORGANIZAÇÃo DA VIDA PRIVADA (PESSOAL, FAMULAR E SOCIAL)}

No eixo temático da organização da vida privada, a maioria dos professores demonstra relações e implicações entre seu trabalho e a vida particular, possibilitando compreender alguns aspectos em que as questões do trabalho docente, do processo saúde-doença e da qualidade de vida se dão de forma integrada. As principais categorias que emergiram foram referentes às impliçações do trabalho na familia e no lazer.

\section{1 - Implicações do trabalho na família}

Na minha casa é assim: eu entro, meu marido sai; eu saio, ele entra. Então eu falo de final de semana, porque durante a semana a correria é tanta (...) Você fica a maior parte da sua vida no trabalho; e aí o convivio familiar é limitado. Há os desencontros dos horários; então o dia que vai sentar, mesmo, para almoçar, para tomar um café, é de Sábado; que eu convivo com meu marido, com meus filhos, entendeu? (S106)... Não tem jeito, você sempre leva alguma coisa para casa (...) E eu chego em casae eu tenho que ver se os gêmeos estão bem, seus filhos querem atenção, seu marido também quer atenção, tem que conversar com o marido porque ele vem e quer conversar. Então todos eles ficam disputando a sua atenção, tá? E tem um elemento de fora, que ele não está ai mas ele também está te disputando e você acaba dando mais atenção àquele de fora do que aos que estão presentes. Então, o que vai acontecendo com o seu emocional? Fica frustrado! (...) Sim, mas essa frustração ocorre também do fato de que você quer dar atenção em casa! (S45)...

A dinâmica de convívio familiar sofre o impacto do trabalho, na medida em que o trabalhador percebe que o seu tempo de convívio e de dedicação à família acaba sendo limitado e restrito a poucos e curtos horários, aos finais de semana; e, também, na medida em que parte do trabalho a ser realizado na escola é levada pelo professor para sua casa, ocupando seu tempo de atenção e dedicação, em detrimento do tempo de convívio familiar. Evidenciamse, aqui, os efeitos sociais do trabalho incidindo sobre o trabalhador e sua familia quanto à utilização do tempo livre e os modos de viver a vida privada, conforme ASSUNÇÃO (1996); BETANCOURT e PALACIOS (1999) e LIMA (2001).

O professor tem consciência disso e sente-se frustrado por não poder se dedicar à própria família à altura das suas expectativas e das de seus familiares; e esse sentimento de frustração pode "contaminar" o sentido e o valor que seu trabalho representam para si e para a 
sua família, desencadeando vivências e sentimentos negativos relacionados ao trabalho e à própria pessoa (ROSA, 1991 e 1994; SORATTO e OLIVIER-HECKLER, 2000-b; VASQUES-MENEZES e GAZZOTTI, 2000).

Aqui, a Fonoaudiologia pode avançar na discussão da qualidade das interações e comunicações que ocorrem entre o sujeito professor e sua família, no sentido de viabilizar situações prazerosas, mediadas pela linguagem e pela voz, dentro das possibilidades existentes na vida dos sujeitos, e que contribuam para a constituição da subjetividade da pessoa que existe - dentro e para além - do ser professor..

\section{2. - Implicações do trabalho no lazer}

Se eu estou estressada, que nem essa semana, que eu tive desfile na quarta-feira - e isso me estressa pra caramba-que eu tive que dar aula à tarde e à noite, e que eu tenho peça hoje e amanhã na escola; eu já estou cansada. Já estou cansada para ir nas festas. Ai eu vou porque tem que ir; eu vou forçada nos lugares, por causa do cansaço do trabalho da semana toda. Não que eu não goste de ir, mas eu vou forçada (S31)... A gente acaba indo, mas, a gente não aproveita como se estivesse descansada, né? A gente vai, né; também não sou daquela "não vou, vai sozinho!"; eu não sou assim, eu vou junto; mas na verdade eu queria ficar em casa descansando (S79)... É, o lazer é necessário, né? Mas, é prejudicado (...) pela questão do estresse; não sei se é bem estresse, mas a gente está cansado, certo? Trabalha o dia inteiro; a gente está cansado e então a gente percebe que isso traz um desgaste muito grande porque você sabe que você precisa sair, mas eu não consigo mais sair. Então quando se sai, já sai cansado, então não existe prazer em sair. Aí o lazer vai embora, isso não é lazer; você sai porque você sabe que tem que sair; entendeu? Então o lazer se torna realmente comprometido (...) Então o trabalho, ele já tira também essa oportunidade do lazer, do prazer, do lazer com satisfação. Então isso é bastante frustrante (S114)... O social, não tem muito lá em casa ultimamente (S45)... Eu acho que o social tinha que ser um pouquinho melhor; falta um pouquinho de (esfrega as pontas dos dedos indicador e polegar como se contasse dinheiro) social! (S70)... Todos(riem e fazem o gesto de dinheiro concordando com S70)... O lazer é prejudicado, primeiro pela falta de condições financeiras (S114)... O nosso lazer? É esse aqui (faz gesto de dinheiro) que está faltando, né? (S41, S70 e S48)... Está faltando bastante (S45)... As vezes, eu estou conversando com os meus colegas e a gente acaba falando "na minha escola aconteceu isso, aquilo"; ai eu falo: "gente, professor só fala disso, vamos mudar de assunto, falar de outras coisas?" (...) A impressão que dá é que a gente tivesse terminando o dia no vermelho com a gente mesmo; porque a maioria de nós aqui expressou uma certa insatisfação com nós mesmos, com o salário, com a questão emocional. Então a impressão que dá é que estamos no vermelho com nós mesmos, como pessoa; nós estamos nos esquecendo de nós mesmos, estamos esquecendo o papel do social da nossa vida; isso se transmitiu nas nossas falas (S91)... Você sabe que, as vezes, eu estou lá num lugar tomando uma cerveja e escuto

"ai, professora, a senhora bebe, heim?" (risos) e é um copinho assim! (indica o tamanho pequenininho com dedos indicador e polegar). Então, onde a gente está a gente é professor! É complicada essa situação! (S112)... Eu acho que é a gente que confunde um pouco estar professor e 
ser professor. Então eu sou professor; e parece que a gente exerce esse papel vinte e quatro horas (S91)...

O professor vê suas possibilidades de lazer restringidas por falta de condições financeiras e pela falta de disposição ao lazer, em decorrência do cansaço e desgaste dos periodos de trabalho. Muitas vezes, o professor abre mão de oportunidades de lazer pela necessidade de repouso e descanso e, outras vezes, acaba participando de eventos sociais ou de "lazer" apenas por conveniência, uma vez que o cansaço o impede de desfrutar daquelas situações com sẻnsações de prazer.

Em diversos momentos de lazer, com a família ou os amigos, são recorrentes o papel social do professor e os temas e discussões dos problemas relacionados ao trabalho, confirmando o fato de que os efeitos sociais do trabalho não incidem sobre o professor somente nos momentos em que ele está em sala de aula, ou durante o tempo do trabalho, mas que se expandem para o tempo vivido fora e além da sala de aula, afetando os modos de viver a vida privada, conforme preconizam autores como ASSUNÇÃO (1996), BETANCOURT e PALACIOS (1999), BORGES (2001) e LIMA (2001).

Nessa perspectiva, cabe recuperar algumas das concepções sobre as quais o trabalho está instituído historicamente: no caso das religiões e, em especial o catolicismo, o trabalho é promovido como forma de realização e dignificação humana, sendo que, o esforço corporal é valorizado e a fadiga é tida como elemento visível da dedicação ao trabalho (NAKAMURA, 1997). Ora, se, conforme já visto (ASSUNÇÃO, 1996; LOURO, 1997; NEVES e ATHAYDE, 1998 e 2001; NEVES e SILVA, 2001; ROCHA e GOMES, 2001) o trabalho docente instituise, principalmente, fundado a partir de um caráter de vocação, decorrente da combinação de elementos do modelo religioso com o da maternidade, que implica, dentre outras coisas, dedicação, doação, humildade, abnegação e sacrificios. Então, nesse trabalho - como em tantos outros -, a idéia de sofrimento e de sacrifício se naturaliza. Nesse sentido, o lazer se apresenta ao professor mais como um elemento de agregação no mundo do trabalho - que produz prazer moderado no sentido de manter certo grau de satisfação com o trabalho para garantir a produtividade do trabalhador - do que propriamente como possibilidades de uma vida mais gratificante, nos termos de NAKAMURA (1997). 
Deve-se considerar que, no conjunto dos esforços, dos sofrimentos, dos sacrificios e das fadigas implicadas com o trabalho, encontra-se o esforço no uso da voz no trabalho; o sacrificio da supressão da fala no convívio familiar e social para poupar a voz para o próximo período de trabalho; a fadiga vocal e geral que leva o sujeito a desanimar e a desmotivar-se perante a possibilidade de participar de eventos sociais e comunitários - apenas lembrando alguns fatores que permitem vislumbrar o impacto do mundo do trabalho na vida privada e na voz.

Nessa perspectiva, as ações em saúde vocal do professor poderiam englobar discussões e reflexões acerca das relações entre trabalho e vida privada - no tocante ao lazer e às oportunidades e condições de que o professor dispõe para vivenciar seu tempo livre, no sentido de suscitar reflexões que concorram para novas possibilidades e para situações gratificantes e prazerosas, que contribuam com respostas às suas necessidades cotidianas, tanto como um sujeito social quanto como um trabalhador. 


\section{3 - USOS DA VOZ NOS CONTEXTOS COTIDIANOS}

Esse eixo temático possibilita ampliar a compreensão da voz docente nas suas associações e interfaces com a linguagem e as interações que essa proporciona - conforme sugere DRAGONE (2000) -, considerando-se os contextos cotidianos nas categorias trabalho e vida privada.

\section{1 - Usos da voz no trabalho docente}

É que nem o pedreiro, para quê os braços do pedreiro? É a mesma coisa do professor com a voz (S70)... E o seu instrumento, né? (S45)... A voz é muito importante dentro da sala de aula; o recurso mais importante que o professor tem dentro da sala de aula é a voz! (..) o aluno sente a necessidade da comunicação do professor falar com ele (S48)... E se você transmite com calma, qualidade (...) todos vão prestar atenção! (...) Uma coisa que fiquei impressionado e que eu quero para mim é não ter que usar assim "ó!" (eleva a cabeça e braço como se estivesse chamando atenção de alguém) para começar a falar (...) não ter que gritar para nada, começa a falar tranqüilo, baixinho e todo mundo ficar preso na fala, sem usar força, sem usar nada (S70)... Às vezes, eu até falo, queria ser um homem com um vozeirão assim (sorri) porque dai a gente tem um potencial maior, né? (S79)... Quando você fala grosso você chama um pouco mais a atenção (...) A única coisa boa de você falar alto e grosso é que você não tem que falar alto e grosso o tempo todo, você fala uma vez e todo mundo já (endireitao corpo olhando para a frente), né? (S70)... Para que serve a voz do professor? Os alunos ficam muito mais interessados na aula, em prestar atenção, em querer aprender (...) ter uma voz forte serve para isso, seve para todo mundo ficar olhando para você e a partir dai você pode diminuir e ficar a vontade (S70)... O ponto principal da aula é você estar ali explicando, estar falando, senão não há compreensão. O dia em que você está péssima: "ah, vou colocar um vídeol" - você não pode colocar e deixar rodar o video lá; você tem que parar e tem que explicar, você tem! (...) Na verdade, a gente deveria manter um relacionamento, uma comunicação através da voz, junto com eles (S48)... O aluno ainda precisa daquela coisa de você conversar, de dar atenção especifica, aquela afetividade - aquela coisa que nós precisamos - e para isso nós temos que falar! (S41)...

Tem hora que você tenta, tenta falar devagar, baixinho at você percebe que não resulta tanto (S106)... Geralmente a gente começa a falar e não quer falar alto né? Mas, sempre tem conversa paralela, a gente chama atenção. Quando a gente percebe já está numa altura tão (aponta para cima) que a voz começa a falhar né? (S79)... Você está numa sala de aula e aumenta a voz para poder ser ouvida e até para chamar a atenção né? (S91)... Você acaba forçando mais, falando mais alto do que deveria, até mesmo pra tentar ter um controle maior (S106)... A voz impõe, né? Isso é importante dentro da sala de aula (S48)... Eu chamo a atenção do aluno e peço "por favor volte para o seu lugar", ai o próprio aluno fala "professor tem que tomar mais" (eleva o corpo e mostra olhar de autoridade). Então você percebe que eles querem uma voz assim! Então, a gente vê como que é algo cultural, né? Talvez em casa eles devem estar habituados com gritos (S91)... É engraçado isso aí, se você falar "por favor" - sim, porque a gente gosta de tratar os outros como gostaria de ser tratado ai... ai eles não atendem. Se fala "vai sentar!" (aumenta intensidade de voz e faz expressão facial de brava), aí eles vão! (S112)... As vezes eu fico lá, passo 1, passo 2, passo 3, sabe, com aquela classe 
cheia, aquele monte de aluno falando alto e eu não consigo atingir os alunos, acabo tendo que escrever na lousa e eu me sinto péssimal (S48)...

A voz é valorizada pelos professores como o principal instrumento ou recurso do trabalho docente, para conseguir a atenção do aluno, assim como na relação afetiva e comunicação professor-aluno no processo ensino-aprendizagem. Essas representações correspondem às considerações recentes de diversos autores da área fonoaudiológica (BEHLAU e PONTES, 1995; MÄRTZ, 1999; DRAGONE, 2000 e 2001; GRILLO, 2000 e 2001 e SERVILHA, 2000 e 2001) e evidenciam que o professor tem, sim, consciência da importância da voz no seu trabalho.

Os professores idealizam uma situação de docência em que todos os alunos depositariam suas atenções em suas palavras; usaria a voz em fraca intensidade, velocidade de fala lenta, pitch ${ }^{l}$ de voz grave, sem gritar e sem esforço vocal, sob uma psicodinâmica vocal de tranqüilidade e de autoridade. É interessante notar que os professores têm predileção por vozes graves, pois tais vozes, segundo BEHLAU e PONTES (1990), representam indivíduos enérgicos e autoritários, o que lhes permitiria obter a atenção do aluno.

Os dados sugerem que o professor tem informação e conhecimento básico sobre algumas das condições ótimas de uso da voz, comumente orientadas pelos fonoaudiólogos, o que significa que ele sabe como deve ser a produção vocal ideal, como deve se dar o uso adequado da voz e o que não se deve fazer. Os mesmos dados mostram também que o professor conhece algumas normatizações sobre o uso da voz - contrariando alguns estudos que apontam a falta de conhecimento, de informação e de orientação sobre condutas vocais desviadas como algumas hipóteses explicativas para o desinteresse dos professores em cuidar de sua saúde vocal (PORDEUS, PALMEIRA e PINTO, 1996 e OLIVEIRA, 1998). Nota-se, contudo, que o professor idealiza uma produção vocal saudável, pautado no conhecimento que possui.

Entretanto, o problema se encontra na concretização e viabilização desses ideários, quando o professor se depara com seus alunos reais os quais não se atêm à sua pessoa nem à

\footnotetext{
${ }^{1}$ Pitch refere-se à sensação psicoacústica de frequência grave ou aguda.
} 
sua fala. Tendo como meta corresponder às condições idealizadas do trabalho prescrito (no qual a voz é o principal e mais importante recurso para obter a atenção do aluno) o professor investe desesperadamente no uso da sua voz falando alto, forçando a voz e até gritando para chamar fazer-se ouvir e controlar a disciplina e, ainda assim, na maioria das vezes não consegue o sucesso esperado. Esse esforço continuado pode levá-lo a desenvolver um quadro de fadiga vocal, disfonia e afonia.

Por assumirem a voz como o principal instrumento do seu trabalho, os professores pensam em recorrer a outros recursos do trabalho dócente - a lousa ou um vídeo - quando se deparam com a impossibilidade de continuar usando a voz. Quando, porém, se utilizam de outros recursos para conseguir a almejada atenção, os professores sentem-se como que atestando o seu fracasso perante seu próprio ideário; daí a frustração e o sofrimento que atingem sua subjetividade, sua saúde vocal e, conseqüentemente, sua saúde geral.

Evidencia-se, aqui, não ser a falta de informação, de conhecimento ou de orientação a responsável pelos problemas de mau uso e mesmo do abuso vocal dos professores, mas sim os elementos emocionais, pedagógicos, educacionais, sócio-interativos, inerentes aos descompassos entre o que se idealiza para o uso da voz no trabalho prescrito e o uso da voz na situação real de trabalho. Lembrando que as questões vocais estão comprometidas com a necessidade de comunicação com o outro nas condições, muitas vezes conflitantes, em que se dá a interação verbal (MARTZ, 1999).

Sugere-se que as ações de saúde vocal passem a levar em conta tais aspectos e questões da organização do trabalho docente a fim de amenizar a carga que recai sobre os professores, quando estes são responsabilizados por desconhecerem ou não seguirem as normas de bom uso da voz; ações que possibilitem avançar no enfoque e na interpretação dos determinantes dos abusos e maus usos e dos problemas vocais de professores, numa perspectiva mais abrangente que englobe, inclusive, temas da educação e da saúde do trabalhador. 


\section{2 - Usos da voz na vida privada}

Como a gente não consegue descansar a voz na escola, então a gente descansa em casa, né? (S1 I6)... Eu participo de um coral e eu ensaio de Sábado e de Domingo. As vezes a semana judia; eu dou aula no periodo da manhã e à noite; cansa, né? Então, as vezes, eu percebo, nos ensaios, que eu não estou conseguindo (S79)... A cada quinze dias eu vou na casa dos meus pais e at junta todos os irmãos e a gente fala muito, né? (...) Ai, gente, eu começo a semana podre! Porque já foi cansativa a semana; aí o final de semana, que você tem para descansar, você fica naquela agitação com a familia! Chega na segunda-feira parece que eu não tive final de semana! (S79)...

No coral eu uso a voz com prazer, entendeu? Nas aulas da escola dominical da igreja a gente usa a voz com prazer (S79)... Se você sai, você conversa, vai num lugar que tem videokê; você canta, aí você usa a voz de outro jeito (S112)... Nós temos um grupo, nós somos uns trinta e pouco professores então a gente faz um jantar temático na casa de um dos professores, al fica todo mundo sem voz... a gente canta, conta piada, brinca, dá risada até quatro horas da manhá. Daí não se fala em coisa de escola, é só descontração, entendeu? Sai todo mundo sem voz, mas enfim a gente aproveita, canta, toca violão, entendeu? Então apesar de ficar sem voz, a gente se diverte (...) é uma coisa assim, a gente descontrai. Sai todo mundo sem voz; a gente fala, a gente canta, a gente grita mas pelo menos você deixa o estresse lá e isso tá sendo muito bom para a gentel (S116)... Tem um grupo de professores - meus amigos também, uns até que não terminaram a faculdade ainda - então quando a gente se reúne não tem nada a ver com escola... é só... é só bagunça mesmo; e eu uso bastante a voz, eu falo à vontade, eu grito à vontade, eu brinco (riso), bebo gelado (S70)...

Evidenciam-se, pelos depoimentos, que os sintomas vocais negativos, decorrentes do uso da voz na atividade docente (fadiga, cansaço, desgaste vocal e perda da qualidade vocal) se mantêm para além da situação de trabalho e exercem impacto negativo sobre as oportunidades de uso da voz na vida privada do sujeito, levando-o a restringir seu uso nas horas vagas, a evitar falar em casa e até a reduzir as situações de comunicação oral com a família.

Em outras situações sociais - especialmente aquelas que envolvem reuniões e grupos de amigos - a voz falada e/ou cantada ocupa papel essencial nas dinâmicas de interação social que se desenrolam sendo, assim, por vezes, abusivo o seu uso. Nessas situações, entretanto, o sujeito não demonstra qualquer preocupação com a saúde vocal e qualidade vocal e, na medida em que essa preocupação com a voz permanece centrada no processo de trabalho e produção, confirma-se, aqui, que a valoração da voz vem se dando unicamente na perspectiva daquilo que representa enquanto instrumento de trabalho.

GRILLO (2001) obteve dados parecidos em sua pesquisa, ao observar que os professores não manifestaram nenhuma preocupação ou cuidados com a voz fora do contexto 
de trabalho. Isso remete a duas frentes de reflexão: por um lado, a necessidade de valorizar as funções da voz enquanto constitutiva da pessoa, do sujeito social, nos contextos de vida privada - e, em sendo valorizada, ser cuidada, também nesses contextos. Por outro lado, a necessidade de se revisar, atualizar e flexibilizar os ideários e as normatizações, tradicionalmente compreendidos no campo da Fonoaudiologia, do que se entende por "cuidar" da voz e da saúde vocal - uma vez que estes são estruturados a partir da experiência técnicocientífica construída, principalmente, no ambiente da clínica corretiva e reabilitadora e que, nem sempre, se aplicam às perspectivas que aqui se propõem, ou seja, de incorporar o cuidado com a voz aos momentos de descontração e de lazer. Isso implica em ampliar o conceito de higiene vocal, no campo fonoaudiológico.

Cabe, ainda, lembrar que o suporte social, oferecido nesse contexto de alegria e descontração entre amigos - muitas vezes sem cuidado algum com a voz - representa, no entanto, forte aliado na proteção à saúde mental e psíquica do trabalhador (HOUSE, 1983; VASQUES-MENEZES e SORATTO, 2000).

Então, além de canalizar esforços para despertar os professores para se identificarem como profissionais da voz e para que percebam a importância, valorizem e cuidem da sua voz como um dos instrumentos de trabalho, os fonoaudiólogos devem também, canalizar esforços para despertar os professores para a valorização da voz nos contextos da vida privada, seja na comunicação familiar ou social - em conformidade com SERVILHA (2001) e DRAGONE (2001).

Talvez, aqui se encontre um aspecto ainda pouco explorado nas ações de saúde vocal, pois, tradicionalmente centradas na questão da prevenção à doença e nos usos em contextos de trabalho, tais ações estão pouco ou nada direcionadas para os usos da voz nos contextos sociais e nas interações em situações de lazer, de descontração e de diversão, contextos em que o uso da voz se dá, por exemplo, no sentido da arte (canto; corais; "karaokês/videokês) ou no sentido do lúdico (piadas, brincadeiras com amigos).

Portanto, em se tratando de promover a importância e valoração da voz e da saúde vocal junto ao professor, não basta somente enfocar a voz na perspectiva da prevenção de doenças ou na perspectiva do instrumento de trabalho e de relação professor/aluno. Nas ações 
de saúde vocal com trabalhadores docentes, é preciso avançar incorporando a discussão da importância e valoração da voz na integridade do sujeito e da sua vida: a voz "da pessoa" e a voz "do trabalhador", dos diferentes papéis e posicionamentos que ele assume no cotidiano familiar e social e no trabalho diário É preciso dar-lhe condições de uso da voz nas diferentes situações e ensinar as possibilidades e variações de recursos de linguagem, de expressão e de comunicação aplicáveis a cada uma dessas situações.

\section{4 - PROCESSO SAÚdE/DOENÇA DO PROFESSOR}

Esse eixo temático envolve as relações entre trabalho e processo saúde/doença docente, cujo aspecto central é a questão da saúde vocal nas categorias que envolvem as maneiras pelas quais o trabalho inscreve o corpo e a saúde do professor, o conhecimento sobre saúde, as preocupações e representações acerca da saúde vocal, assim como as formas de interpretar os problemas vocais e as maneiras de enfrentá-los.

\section{1 - Implicações do trabalho docente no corpo e processo saúde/doença do trabalhador professor.}

Você já chega assim, você sabe que lá naquela sala você não vai conseguir atingir $50 \%$ dos alunos; então você ja, meio que na metade do caminho, dependendo da sala - a sensação é péssima, né? Você já sabe que vai para aquela sala e que lá não vai conseguir atingir, porque metade vai estar dormindo, metade com o walkman. É uma coisa assim, antecipado, né? Acontece antecipadamente, antes de você entrar na sala de aula! (S48)... Por isso é que eu não decoro o horário, assim eu nunca sei onde eu vou! Então eu não tenho que ir sofrendo daqui até lá. Não! A hora que eu vi, já estou lá! (S41)... Eu acho que esse sofrimento reflete na voz; você já vai tensa (S116)... E isso. Eu acho que a questão da qualidade da voz acaba sendo uma conseqüência disso tudo! (S91)... Ai o problema é esse, quando vai para o corredor da morte, né? Ali nós chamamos de corredor da morte; é isso aí, você já sobe gritando pra eles pararem de gritar. Eles rolam pelo chão, eles correm no corredor, eles gritam, jogam papelzinho um no outro, né? Então você já começa gritandol (S41)... E isso é na entrada, entendeu? Eles fingem que não te vêm. Você passa, eles virame disfarçam. Você tá lá dentro ai você 
dá um tempo, porque existe um tempo que você pode dar até. At você vai até a porta e pede educadamente para que eles entrem, mas automaticamente você já está alterada, porque você já viu que não foi percebida ou que eles estão te ignorando (S106)... Ai eu já me sinto irritada. Eu já sinto que eles não querem entrar para a minha aula; ai eu já começo a ficar irritada, aí já começo; at já começa assim, a doer aqui (aponta a laringe); parece que vai fechando... a voz. Por que como eu não posso descarregar aquela raiva que eu estou sentindo - porque eu estou com raiva mesmo, a palavra certa é essa! - Ai eu tento... dou uma respirada fundo pra começar a aula (S123)... E eu falo que eles respeitam muito mais a porta do que o professor, porque é só você fechar a porta que eles entram. Porque você pode ficar ali. Aí dá uma sensação horrivel (...) porque, olha: nós entramos, eu vou na mesa, coloco o material, eu já chego na porta, falo bom dia, volto, e eles não tão nem aí.. nem ail! Mas aquilo, eu já... sabe, eu já fico irritadissimal Dai na hora que eu vou fechar a porta tem um empurrando a porta; dá vontade de deixar tudo para fora! (S79)... Eles passam em cima da gente, pisam no pé (S112)... A voz não é o início, é o fim; porque nós chegamos bem, só que aquela tensão, aquele emocional alterado, vai fazendo com que sua voz se modifique (...) É o emocional; se eu ficar tensa em sala de aula por causa de conversa, o negócio (aponta o pescoço referindo-se à voz) some na hora (S1 16)... Eu falo: "gente, eu vim aqui para dar aula pra vocês, vocês não querem assistir?"... "Vocês não querem minha explicação?"... perde o sentido, né? "Então o que eu estou fazendo aqui?" Ter que implorar para assistir minhas aulas, uma coisa que vai beneficiar eles e que vai fazer eles crescerem!? (S112)... Nossa, dá uma frustração! Ai gera uma insatisfação grande do próprio trabalho! (S91)... E depressão! (S112)... Você sabe aquilo, você quer passar aquilo para o aluno; a gente acha importante aquilo; você começa a falar - eu até acho que eu consigo colocar minha voz, uma entonação - mas quando começa uma conversinha aqui, outra conversinha ali; isso vai me irritando, aí, minha voz começa... minha garganta começa arder, ai eu já estou falando alto. $E$ eu também falo rápido; parece que você, querendo falar rápido, está querendo chamar atenção ao mesmo tempo; mas, o objetivo principal é você ver o resultado, que o aluno se interesse por aquilo que você está falando. E isso frustra, frustra muito! (S79)... Eu acho que a frustração que a gente sente na sala de aula, quando você está querendo chamar a atenção para si para passar o que está proposto, essa frustração, ela continua apresentando e nós não conversamos a respeito! Aí você lembra: "hoje eu não conseguil Eu tive que chamar a atenção, que tentar chamar a atenção!" Então, essa frustração, ela não é só naquele momento, ela perdura, entendeu? (S106)... Aí influencia em casa... em casa influencia... você chega diferente, ai já atinge a auto-estima (S31)... E eu tenho consciência, sempre a frustração, o seu problema, reflete no que você tem de mais frágil. E, no meu caso, eu tenho consciência que é a minha voz (eleva as duas mãos ao pescoço e olha para todo o grupo), entendeu? Eu tenho consciência disso, eu sei que se eu tiver frustrada, por qualquer que sejao motivo, o primeiro que eu vou ter é dor de garganta e voz. Porque reflete no meu ponto frágil, cada um tem o seu $(\$ 45) \ldots$

Na hora da HTPC é aquele estresse, né? Todo mundo já deu cinco, seis horas de aula e tem que ficar mais uma hora lá; então é aquele estresse total! (S116)... E fala todo mundo junto! Eles falam todo mundo ao mesmo tempo! (...) Para o representante passar um recado ele tem que ficar pedindo para parar de falar. E os professores falam muito alto (S114)... Eu acho que é um desrespeito com quem está falando, quem está lá na frente tentando passar o recado; e a gente nem percebe! (S45)... Ah não, percebe sim! Eu me sinto mal. Todo mundo fazendo barulho na hora que vai ser dado o recado, é complicado/ Eu me sinto muito mal! (SI 16)... É a verdadeira sala de aula, um aluno fala como outro, o outro com outro, e muito alto, e ninguém escuta nada (...); uma situação bastante constrangedorae comum (S114)... E os assuntos da HTPC são assuntos conflitantes, são ordens que vêm de cima, de fazer coisas que a gente acha que não tem sentido a gente fazer (S116)... Então, aí começa a conversa paralela dos professores, um querendo reclamar e desabafar com o outro (S112)...

Em um outro trabalho, quando terminou o expediente, acabou; não vai para casa pensando: só no dia seguinte, né? Já o nosso trabalho está tão ligado ao emocional (S91)... Esse é o maior problema, 
porque onde você vai você carrega as coisas com você; a nossa grande dificuldade é exatamente essa, você não deixa seus problemas lá na escola, você leva junto, Você vai para casa e carrega junto com você (S114)... Essa questão de levar da escola para casa nem sempre é apenas uma atividade; às vezes é o seu emocional (...) Você sai vinte para as onze da noite e às onze eu chego em casa e, por exemplo, ontem à noite eu discuti com um aluno, tive que mandar ele para a direção e aí, no intervalo, ele "ah, eu vou te quebrar!" e mais umas coisas... Quero dizer, fica muito conflitante! Eu cheguei em casa e ainda estava com a cabeça pensando no quê eu devia ter feito que eu não fiz... Então a gente carrega isso para casa, né? (S9l)... Às vezes, eu saio da escola, já desabafo no carro; eu até comento alguma coisa com meu marido, ai ele já fica mais bravo que eu (...) eu chego e conto quando eu brigo com algum aluno; meu marido escuta, dá um palpite (S79)... Eu tive um problema muito sério no ano passado, de problema estomacal. Porque eu trabalho à noite, né? E eu chegava e comia o que tinha na frente, porque era uma ansiedade tão grande; parece que eu queria morder o mundo, e não podia; então eu comia tudo e... eu engordei. Me causou um problema de digestão à noite, que afeta a dor de cabeça no dia seguinte, entendeu? Então isso melhorou, mas ainda de noite eu não posso comer; eu chego em casa e o meu marido fala "vem comer alguma coisa" e eu não vou, porque eu sei que no dia seguinte vai atacar vesícula, estômago, dor de cabeça, enxaqueca direto, então eu parei de comer... porque eu sei que isso é o nervoso; é o nervoso que você traz consigo, entendeu? Então eu chego em casa e o meu marido fala "deita, que você está cansada!" Mas eu não posso, eu não consigo, porque dai eu não durmo, eu só fico revendo as situações: "ah, aquele fez isso, aquele fez aquilo" ou "eu poderia ter feito isso, ter feito aquilo, ter dito isso, ter dito aquilo" (S106)...

O sofrimento psíquico do professor inicia-se muito antes de ele chegar na sala de aula. A caminho da sala de aula o professor debate-se com pensamentos e julgamentos sobre os alunos, antecipa problemas e enfrenta os conflitos e dificuldades de relacionamento e comunicação com eles. Nesse processo, desenvolvem-se emoções e sentimentos negativos de irritação, desconsideração, desrespeito e raiva, e o professor começa a usar sua voz nesse contexto tenso e conflituoso, a fim de tentar recolher os alunos para a sala de aula e de se fazer notar e ser respeitado como pessoa e como profissional, nesse ambiente.

Nessas condições, o uso da voz já não se dá de maneira tranqüila ou saudável. Pelo contrário, o professor propende a gritar; pois, conforme CRAGNO (1992), a voz traduz grande parte da carga afetiva e emocional implicada na prática cotidiana docente. Reflete, também, dificuldades de relacionamentos com os alunos, com os colegas e superiores hierárquicos, no manejo da disciplina, na falta de adaptação às mudanças do processo de ensino-aprendizagem, dentre outros aspectos que, segundo o autor, levam o professor a reações de nervosismos, impulsividade, agressividade, insegurança e angústia, com impacto negativo sobre a produção da voz e saúde vocal. 
Iniciada a aula, o professor vivencia sentimentos de frustração, desânimo e perda do sentido do seu papel como trabalhador; uma vez que as expectativas que tem sobre seus alunos e o desenrolar do processo ensino-aprendizagem (trabalho prescrito) não correspondem à maneira como estes se apresentam e se desenvolvem no trabalho real. $O$ uso da voz ocorre nesse contexto, muitas vezes destituído de sentido é permeado pelas tensões que resultam das diferenças e conflitos de interesses e de objetivos, contribuindo para um quadro que pode ter desdobramentos como o abuso vocal, o mau uso vocal, a fadiga vocal e disfonias do tipo disfonia de tensão muscular, que ocorre em pessoas que fazem uso extensivo da voz sob situações estressantes (MURRAY et al., 1983).

Nas reuniões de HTPC, reproduzem-se, nos relacionamentos entre professores e a equipe de coordenação/administração, os sentimentos de desconsideração e desrespeito e os conflitos de interesses e de objetivos vivenciados em sala de aula. Na HTPC, Coordenação e Direção reproduzem as posturas autoritárias e impõem assuntos, normas e decisões para os professores, muitas vezes, a despeito da divergência de interesses, idéias e opiniões. Assim como fazem os alunos em sala de aula, na HTPC os professores também não ouvem nem prestam atenção aos próprios colegas ou dirigentes que estão falando, levando-os a gritarem para que possam ser ouvidos.

Mantêm-se e se renovam, nos contextos das reuniões do corpo docente, os sentimentos e as emoções negativas vivenciadas nos contextos de sala de aula; sentimentos e emoções que, conforme CRAGNO (1992), exercem impacto desfavorável sobre a voz e na saúde vocal do professor. Então, a problemática das condições sociais de uso da voz - que interferem na saúde vocal docente - deve ser compreendida de maneira abrangente nos diversos contextos cotidianos que configuram as condições do trabalho docente - não se restringindo às situações que ocorrem dentro da sala de aula, pois está evidente que a problemática antecede, perdura e se estende além dessas situações.

Os problemas originados e vivenciados no contexto de trabalho, especialmente aqueles que se referem aos conflitos, tensões, discussões e brigas com os alunos, acabam sendo transportados para a casa do professor e se estendendo para a sua vida privada, consumindo parte da energia psíquica e afetando os relacionamentos familiares, a saúde e a 
qualidade de vida desse trabalhador. Esses resultados corroboram as considerações de NÓVOA (1995), de que vida profissional e vida privada interagem e afetam-se mutuamente no processo saúde-doença docente, gerando nervosismos; frustrações; ansiedades, insônia, obesidade e alteração dos hábitos alimentares. Dai os problemas gástricos e digestivos; dores de cabeça e enxaquecas; dores de garganta e problemas vocais agravantes de uma disfonia.

Esses resultados confirmam que as relações estabelecidas entre professor/aluno incidem de diversas maneiras nas 24 horas do dia e na vida do professor, além de que reafirmam o trabalho como núcleo fundamental e constitutivo de subjetividades que exerce efeitos sociais nos trabalhadores, que se expandem para o tempo vivido fora e além da sala de aula (ASSUNÇÃO, 1996; BETANCOURT e PALACIOS, 1999; LIMA, 2001).

Então, novamente, a ação direcionada à promoção da saúde vocal do professor não se pode restringir à atenção aos aspectos específicos da voz (conhecimento do aparelho fonador, orientações de cuidados com a saúde/higiene vocal, usos/abusos e realização de exercícios vocais). A atenção a esses aspectos específicos deve estar inserida numa atenção ampla às condições de trabalho, saúde e qualidade de vida, levando em conta os diversos fatores cotidianos que exercem impacto sobre a qualidade de vida e saúde (geral e vocal) do professor para criar condições de intervenção na realidade cotidiana, no sentido de transformá-la e melhorá-la.

Em suma, o processo saúde /doença vocal há que ser compreendido como parte do processo saúde geral e da qualidade de vida do professor. Nessa perspectiva, as tradicionais intervenções que se limitam à realização de palestras ou triagens esporádicas não respondem a essa assertiva. Há que se buscar ações que se voltem para a realidade de vida dos sujeitos, envolvendo a comunidade escolar, de maneira participativa, em abordagens de característica processual e seqũencial. 


\section{2 - Noções de higiene vocal/saúde vocal}

Pode ver que eu estou aqui, mas estou sempre tentando não pigarrear de alguma maneira (e engole a saliva) (S45)... Tem hora que você tenta, tenta falar devagar, baixinho, você percebe que não resulta tanto, ai você continua; e essa (aponta o pescoço) é a conseqüência (S106)... A gente vai competindo com eles e vai elevando, elevando a voz (gesto de elevação com a mão) (S1 16)... A questão de falar alto é uma questão de educação; nós somos educados a falar alto, a gritar! Então essa semana eu estava em sala de aula e tinha uns moços como som ligado na rua, perto da papelaria. O som era tão alto que não dava pra gente ouvir nada dentro da sala, vibrava o prédio; agora você imagina essa gente dentro do carro com um som daquele, ninguém ouve nada! (S114)... Eles gritam entre si, eles estão conversando aqui e gritam um com o outro; eles também não estão ouvindo bem, ficam com aquele walkman alto o tempo inteiro e vão perdendo sensibilidade auditiva (S116)... Para mim não é tanto o problema de barulho na sala de aula, é problema de falar muito mesmo, o meu problema é explicar, porque se são dez aulas, são dez aulas explicando. Então a agüinha ali do lado, chego a tomar dois, três litros no dia, a agüinha ali do lado porque eu falo muito! (S31)...

Observa-se que o professor tem conhecimento e está informado sobre alguns "cuidados", "regras" e "normas" básicas de higiene/saúde vocal. Esses dados não são condizentes com a literatura fonoaudiológica, que apresenta o professor como um sujeito que desconhece e é desinformado a respeito de muitos dos hábitos nocivos à saúde vocal (OLIVEIRA, 1998).

Os professores sabem, por exemplo, que o pigarro é prejudicial e evitam pigarrear engolindo saliva; procuram usar a voz em fraca intensidade e sabem que o desgaste vocal é decorrente do uso intensivo da voz em intensidade forte ou do grito; identificam questões sociais e culturais relacionadas à intensidade de som e uso da voz e da ocorrência de competição sonora em muitos contextos cotidianos; identificam questões didáticopedagógicas referentes ao modelo de ensino-aprendizagem em que se baseiam; sabem da necessidade de hidratação laríngea e bebem água durante o uso profissional da voz - aspectos indicados na literatura sobre higiene/saúde vocal (PINHO, 1997; SILVA, 1998; BEHLAU e PONTES, 1999; FERREIRA e SILVA, 2002).

É possível que os dados aqui apresentados estejam demonstrando um dos resultados positivos das ações educativas realizadas pelos fonoaudiólogos no campo de intervenção preventivo-comunitária, dos quais um exemplo são as Campanhas Nacionais da Voz, que ocorrem anualmente, desde 1999. Também o fato de alguns professores que participaram do 
grupo focal terem tido experiência prévia de atendimento fonoaudiológico e/ou de acompanhamento fonoaudiológico em grupos realizados na própria escola, ajuda a confirmar a percepção de que os conhecimentos básicos de saúde vocal começam a fazer parte do repertório coletivo e conhecimento partilhado da categoria docente.

Então, mais uma vez, o foco de atenção e de ação em saúde vocal docente não deve se limitar à tradicional difusão da informação e do conhecimento e prescrição dos "cuidados", "normas" e "regras" de higiene vocal. O professor precisa muito mais do que conhecer as informações e orientações de higiene/saúde vocal; ele precisa mudar as suas atitudes, e issó envolve um processo de conscientização e de reflexão mais amplo e mais abrangente, direcionado à sua vida pessoal e profissional (GRILLO, 2001). 


\section{3. - Preocupações e representações referentes ao processo saúde-doenca vocal}

Eu tinha esse problema não é de hoje não, então você antigamente achava até que era normal. Agora você sabe que é um problema, que tem como estar tratando; porque antigamente nós achávamos até que era normal e continuávamos, né? (S106)... Dá problema de calo nas cordas vocais (...) e, às vezes, quando você detecta o problema já é para o ponto de cirurgia (S91)... Por isso que eu estou com medo, viu! Porque eu sou jovem ainda e acho que estou usando muito minha voz, usando muito. Eu acho que, não sei como vai ser no futuro, estou com medo. Estou com medo! (S70)... Eu fiquei preocupada com tumor, porque o ano passado minha voz sumiu completamente; $o$ ano passado fiz uma laringoscopia para ver se não tinha tumor. Eu falei: "eu posso ter um tumor", né? (S116)..

Em conformidade com a literatura (DRAGONE e col. 1999; OLIVEIRA, 1999 e VAZ et al., 1999 e 2002\}, os professores reconhecem que anteriormente costumavam considerar a rouquidão como voz "normal", "habitual" e "natural", no contexto da docência. Entretanto, surge um dado novo e essa concepção de processo saúde-doença vocal começa a mudar, na medida em que os professores passam a interpretar a rouquidão como indicativa de problemas de saúde vocal e geral. É possível que essa alteração nas percepções dos professores seja resultado das informações veiculadas pela ocasião das Campanhas Nacionais da Voz, da experiência particular de alguns docentes que vivenciaram problemas de saúde vocal ou, até mesmo, das ações fonoaudiológicas, no campo clínico ou preventivo e comunitário a que os professores foram expostos.

Se, por um lado, essa forma de interpretar a rouquidão sinaliza um avanço em termos de "conscientização" e de educação em saúde da população docente - conforme aumenta a preocupação em relação à saúde vocal -, por outro lado, observa-se que o processo saúdedoença vocal docente encontra-se imbuído da representação da existência de uma alteração orgânica em estado avançado e do medo e dos demais sentimentos negativos que essa idéia provoca. Em outras palavras, a rouquidão, antes supostamente "ignorada" pelos professores, agora é por eles interpretada como uma doença, ao ser associada à idéia de diagnósticos médicos como "nódulos (calos) vocais", "tumores" ou "câncer de laringe" e a indicações de intervenções cirúrgicas, o que deixa o professor amedrontado. 
O fato de os professores interpretarem os sinais de desgaste vocal e perda da qualidade vocal a partir de uma representação de processo saúde-doença que relaciona a alteração vocal a problemas mais graves que requerem estratégias de intervenção e terapêuticas invasivas, complexas e agressivas - e que, em decorrência disso, anteciparem sentimentos negativos e assustados como o medo de serem diagnosticados como portadores de alguma doença gravepode ser um aspecto importante que contribui para que os professores venham a se sentirem intimidados ou até mesmo que se esquivem da possibilidade de procurar uma avaliação vocal com um profissional especializado.

Esses dados podem estar indicando a necessidade de se revisar o foco atribuído às ações de educação em saúde vocal, lembrando que, mesmo as Campanhas da Voz têm enfatizado a questão do cuidado com a saúde vocal pela via patologista e organicista que toma, como foco principal, o tema da prevenção do câncer de laringe.

Sugere-se, portanto, um redirecionamento temático nas ações em saúde vocal do professor, no sentido de priorizar os temas e questões relacionadas aos usos cotidianos da voz, nos contextos de vida diária, abstendo-se, na medida do possível, do apelo dramático. Devemse valorizar sempre os recursos educativos e terapêuticos que se mostram menos ameaçadores, menos agressivos e traumáticos, de maneira a contribuir para a desmistificação do caráter "assustador" e "amedrontador" que parece envolver a disfonia, sem, contudo, subestimar ou banalizar a problemática do processo saúde-doença vocal docente. 


\section{4. - Percepção e identificação de um problema de voz/saúde vocal}

No começo eu percebo que começou a alterar, estava ficando rouca; at perdi a voz. Esse ano eu fiquei acho que uns 2 meses muda, fiquei muda, fechei a boca e não falei mais. Eu fiquei mudal Fiquei um mês e meio ruim, tomando remédio porque não sata, inflamou tudo e eu não conseguia falar! (S41)... Por ter essa coisa de falar alto, eu estou começando a ter dores, à noite; eu tenho dores aqui (mostra a região da laringe), não sei se é as cordas vocais que tem algum problema (S112)... Eu percebo que eu estou com problema de voz quando eu começo a tossir; você começa a sentir que arde, mesmo você ficando com a água do lado, quando (passa a mão no pescoço indicando dor na laringe). Mas, é a partir do momento que você começa a sentir arder, a sentir aquele incômodo que você percebe que está com um problema (S45)... Um dia ou outro você fica meio assim (pigarreia); dá uma engasgadinha; é um negócio assim, quando você está falando e sai um mais fino, sabe? Mas até hoje eu não tive problema nenhum de voz (S70)... O meu é isso, a voz fica falhando, olha ai! (a voz falha na hora) (S116)...

GRILLO (2001) e FERNANDES (1998) observam que professoras de pré-escolas se queixam de terem uma vida muito agitada, com excesso de compromissos e de tarefas a realizar, que não lhes possibilita pensarem em si mesmas. Assim, é possível que a organização da vida cotidiana, no trabalho e na vida privada, não esteja contribuindo favoravelmente para que os professores possam interpretar os sinais vocais desde o início do desenvolvimento de um problema vocal. É importante lembrar que 69,5\% dos sujeitos dessa pesquisa são do sexo feminino e que a maioria dos professores leciona durante 2 periodos e que $32 \%$ lecionam durante 3 periodos, indicando a possibilidade de ocorrência de acúmulo e sobrecarga de trabalho doméstico e cuidados familiares mais a profissão.

Os resultados demonstram que os professores interpretam alguns sinais indicativos como significativos e representativos de problemáticas vocais; enquanto que outros desses indicativos, ainda que percebidos pelo docente, são destituídos de importância e de significação, no sentido de que os levam a interpretar as suas condições de saúde vocal como problemáticas ou carentes de atenção e de cuidados. A percepção e a identificação dos problemas de voz como saúde vocal ocorre no contexto das representações sócio-históricaculturalmente constituídas pelos grupos que compõem a sociedade (LAURELL, 1982; MINAYO, 1997-c). Evidencia-se que os indicativos mais facilmente interpretados em sua provável relação com problemas de saúde vocal são aqueles que provocam sensações físicas e corporais de desconforto significativo, como o ardor e a dor ao falar, a tosse e as infecções de laringe. 
Os professores também interpretam as mudanças evidentes da qualidade vocal, como a rouquidão e a perda total da voz (afonia) como indicativos significativos e representativos de problemáticas vocais. O pigarro, os engasgos, as falhas e quebras da sonoridade na voz e a instabilidade fonatória não são interpretados como indicativos de problemas, seja na produção e qualidade vocal ou na saúde vocal.

Os dados sugerem que, para a percepção e interpretação e atribuição de sentidos aos sintomas, os professores podem estar se baseando, principalmente, em representações de problemas vocais de base orgânica - em representações de processo saúde-doença que se dá pela via orgânico-biológica - o que poderia levá-los a se mostrarem tão pouco sensíveis para interpretar os indicativos de característica perceptivo-auditiva que evidenciam-se na produção e variação da qualidade vocal.

Fazem-se necessárias pesquisas mais aprofundadas para melhor conhecer as representações que medeiam as relações que o professor estabelece com a sua voz, com a qualidade vocal que envolve o processo saúde-doença vocal. Assim, partindo do conhecimento das representações dos professores, trabalhar com eles o desenvolvimento da capacidade de atenção, percepção e reconhecimento da própria voz e das suas qualidades, bem como das mais sutis variações, mudanças e transformações, passíveis de serem notadas, na sua própria qualidade vocal, nos diversos contextos cotidianos de usos da voz. O professor precisa estar sensivel aos indicativos que a sua voz lhe oferece no dia-a-dia para interpretá-los como componentes do processo saúde-doença vocal docente. $O$ processo de sensibilização desse trabalhador deveria iniciar-se no contexto dos cursos de formação de professores, por meio de ações fonoaudiológicas. 


\section{5 - Estratégias de enfrentamento das alterações/problemas de voz}

Porque é aquela coisa, geralmente acontece isso: eu vou ver o que está acontecendo quando já surgiu o problema né? (...) Então não é algo que a gente tem que tá, assim, procurando, tem que tá atento. Mas, é dificil, né? (S91)... Com essa voz aqui (aponta o próprio pescoço) você fala uma coisa e as pessoas que estão perto de você (tampa as duas orelhas e sorri) né? Então, eu já tive problema de rouquidão, no início eu cheguei até a tirar licença, não conseguia falar. Hoje já estou habituada, minha voz é mal colocada e eu tenho um calo na corda vocal (S48)... Você está habituada a falar em voz alta o tempo todo (...) você está tão acostumada (gesto elevando as mãos) com seu tom de voz que você não consegue mais falar baixo; então não é só em sala de aula, você acaba forçando o tempo todo e é isso que vai estressando (S45)... A gente percebe que até no dia-a-dia mesmo, as pessoas já estão acostumadas a ouvir tudo muito alto (...) assistem televisão muito alto, colocam o walkman muito alto e, com certeza, na sala de aula eles vão falar alto também (S91)... Eu já fiz tratamento com fonoaudióloga. No ano passado fiz uma laringoscopia para ver se não tinha tumor. Não tem! Então eu cheguei num ponto que vou continuar assim até eu me aposentar; porque não adianta, e eu não tenho paciência pra (trrrr - faz o exercicio de vibração de língua), né? Isso dai eu não tenho paciência; de fazer o relaxamento, né? As vezes, eu vou no carro (com as mãos faz o gesto de segurar o volante dirigindo e-trrrr) até lá na escola. Mas eu não tenho paciência. Então eu já nem estou conseguindo fazer aquilo mais, entendeu? Mas, assim, o dia que eu estou pior, evito de falar muito, o dia que estou melhor, eu falo bastante e dai eu fico pior. Mas eu acho que vai ter que ser assim para o resto da vida (S116)...

As estratégias que o professor utiliza quando percebe que está sofrendo de um problema de voz são variadas, e demonstram diversas dificuldades tanto no enfrentamento da problemática como na busca de soluções efetivas e adequadas para a melhoria da saúde vocal.

Notam-se resistências em buscar precocemente uma avaliação vocal e a ocorrência de estratégias paliativas, como as licenças de saúde, que são conseguidas sem a realização de um acompanhamento terapêutico que possibilite, ao professor, identificar as suas reais necessidades ou que o conduza à discussão, à reflexão e à transformação dos fatores predisponentes, determinantes ou agravantes do seu problema de saúde, que se encontram presentes nos contextos cotidianos e qualidade de vida (PENTEADO e BICUDO-PEREIRA, 1999). Notam-se reações de acomodação, de conformismo e tentativas de "naturalização" em relação aos problemas vocais - que podem ser indicativas de tendências pessoais e coletivas da categoria docente ou mesmo de experiências particulares anteriores com tentativas de tratamentos não concluídos e/ou mal sucedidos. 
Nesse sentido, destaca-se, aqui, o sujeito que se habituou com a sua voz mal colocada e com o fato de ter nódulos vocais; o outro que fez acompanhamento fonoaudiológico, mas não mantém os cuidados necessários para a preservação da saúde vocal; aquele com uma voz altamente disfônica que se contenta com o fato de saber que não tem um tumor na laringe mas que, no entanto, não encontra energia nem disposição para buscar ajuda que possa melhorar a sua qualidade vocal; o outro que, habitualmente, usa mal e abusa da sua voz e tenta justificar sua atitude pelo reconhecimento de que se trata de uma cultura geral de abuso vocal, de maneira a "diluir", na sociedade, a sua responsabilidade para com a própria saúde.

Os dados sugerem que os professores têm necessidades que correspondem ao campo de ação fonoaudiológica em saúde vocal coletiva, os quais vão muito além daquilo que as tradicionais ações informativas e normativas costumam oferecer. Tais necessidades encontram-se permeadas pelas representações e concepções de saúde, de promoção da saúde e de processo saúde-doença socialmente constituídas, o que nos leva a acreditar que as transformações possíveis no campo da promoção da saúde vocal docente devem passar, necessariamente, por processos de conhecimento, discussão, reflexão e de mudanças nos referenciais simbólicos, além dos processos subjetivos e intersubjetivos que determinam e mantêm tais representações e concepções.

As ações de promoção da saúde vocal do docente devem ter seus objetivos e focos de ação ampliados a ponto de incluírem as questões da organização do trabalho, das concepções de processo saúde-doença, de subjetividade e da qualidade de vida como componentes importantes da saúde, a fim de que possam constituir-se como possibilidades concretas para apoiar e orientar o professor na busca de estratégias e recursos eficientes que apresentem respostas às questões, e soluções para os problemas de saúde vocal. 


\section{II - PROCESSOS DE INTERANIMAÇÃO DIALÓGICA}

Considero, aqui, as informações complementares que se mostraram relevantes durante a realização do grupo focal, emergentes dos dados de conteúdos e representações subjacentes ao que está manifesto, expressos nas tendências e na organização do discurso, no investimento afetivo, nos gestos, nas posturas, nas expressões faciais e mesmo nos silêncios.

Em geral, houve concordância entre as colocações de todos os participantes em praticamente todas as temáticas e assuntos abordados no grupo focal. A única posição discordante do grupo refere-se à questão das relações entre trabalho e vida privada, em que somente um professor sustentou firmemente sua posição contrária à do grupo, no sentido de que compreende o contexto de vida privada como adverso ao do trabalho e vice-versa, afirmando, categoricamente, conseguir realizar tal distinção na vida cotidiana:

Eu não levo para minha casa e também não estou preocupada com aquele monte de prova que eu não vou corrigir não. Se eles querem que eu corrijo, eu corrijo lá; para a minha casa eu não vou levar! $E$ outra coisa, se eu levar problema da minha casa para a escola eu não dou aula e se eu levar problema da escola para minha casa eu não fico em casa, então tem que separar as coisas, trabalho é trabalho; senão você começa misturar sua vida pessoal com trabalho e dai fica um rolo! (S41)...

No decorrer do grupo focal, tornou-se evidente a dificuldade e o desconforto dos professores em abordar e discutir questões referentes à temática da relação professor/administração-coordenação:

P - Como é a relação dos professores com o nivel administrativo, direção, coordenação?

Todos- (silêncio e risos)

\$4 I- (bate palmas 3 vezes, sorri e apóia os cotovelos sobre a mesa escondendo o rosto com a mão e abaixando a cabeça)

S48-Ó! (faz gesto de silêncio passando indicador e polegar juntos sobre os lábios fechados, como se fechasse um ziper e sorri).

S70- Desliga a câmara primeiro, depois a gente fala...

S41-Desliga, apaga a luz...

Todos- (risos)

S4l-Blim, blom! (e bate palmas)

(...) 
P- Evocês conseguem se colocar para a coordenação? Há diálogo?

Todos- Há ... Ah não!!! (risos). Há não! Não há (risos)...

Note-se que a qualidade vocal e a linguagem oral comportam conteúdos e representações de sentimentos negativos como raiva e ódio, ao mesmo tempo em que sinalizam tentativas de obscurecimento e de silenciamento, nas tentativas de mudança de assunto, na preocupação em saber se a filmadora estava ligada e nas "brincadeiras" solicitando apagar a luz da sala ou desligar a filmadora; e, também, em sonorizar com a voz representando o toque de uma campainha.

Os silenciamentos são indicados por meio de alguns gestos, posturas e expressões faciais tais como o riso; colocar as mãos na cabeça; tampar o rosto com a mão e a baixar a cabeça; balançar o dedo indicador em riste; bater palmas pedindo silêncio; o gesto de fechar a boca passando um zíper com a mão sobre os lábios, dentre outros.

A organização do discurso evidencia mudanças de tópicos discursivos, silenciamentos e mudança do sujeito do discurso - passam a falar em nome dos alunos quando a pergunta refere-se aos próprios professores:

Os alunos comentam que a direção os trata mal; não os ouve e eles querem ser ouvidos (S106)...

O coordenador pedagógico da escola... tá filmando, né? (olha para a câmara) tem aluno que tem ódio mortal dele (S112)...

Os dados evidenciam a existência de uma relação bastante conflituosa, tensa e problemática entre professores e diretores/coordenação pedagógica. Observa-se que o tema da qualidade dessa relação social, além de não ser tranqūila ou naturalmente abordado pelos sujeitos envolvidos, tende a ser um tema negado, silenciado e excluído das discussões referentes às condições e à organização do trabalho docente. 
A opção metodológica realizada nessa pesquisa mostrou-se importante, também, por oferecer, aos sujeitos envolvidos, oportunidades de reflexão, de diálogo, de discussão e de tomada de consciência da sua realidade de saúde vocal e geral, de vida cotidiana e da sua subjetividade - que implica em serem pessoas e serem trabalhadores. Nesse sentido, merecem ser citados alguns episódios discursivos dos professores participantes do grupo focal:

Eu acho a proximidade desse encontro aqui fantástica (...) Então a impressão que dá é que estamos no vermelho com nós mesmos como pessoa; nós estamos nos esquecendo de nós mesmos, estamos esquecendo o papel do social da nossa vida... isso se transmitiu nas nossas falas (S91)...

Ah, eu acho que, assim, foi que nem uma terapia, né? A gente tem poucos momentos de falar, de expor os nossos problemas... para alguém ouvir, alguém para nos ouvir, porque é dificil isso at, né? Ter alguém para ouvir... Então é tranqüilo por causa disso, né? Vai fluindo, vai saindo (S.31)....

Eu acho que para mim foi legal! (S112)... Eu achei importante porque a gente fica angustiada, às vezes. Eu sou uma pessoa bastante fechada, então, às vezes, eu converso só na minha casa, né? Porque eu não tenho familia aqui, tenho poucos amigos, eu não sou daqui, moro aqui há alguns anos. Então a gente acha que só a gente está passando por aquilo e, então, o que eu percebi aqui é que as mesmas coisas que eu estou sentindo, não é só comigo, é com vocês também; os mesmos problemas que eu estou enfrentando Então eu estou assim, me sentindo um pouco melhor; não estou me sentindo tão culpada, me sentindo como uma espécie rara. Então o que está acontecendo comigo não é só comigo; o problema não está comigo, está na nossa profissão, né? (S123)...

Esses episódios demonstram que o grupo focal pode desempenhar um papel de informação, de trocas de experiências e de construção de saberes, reafirmando, aqui, o caráter pedagógico e transformador desse tipo de ação junto a trabalhadores (CARNEIRO, 2000; RIGOTTO, 1993 e BETANCOURT e PALACIOS, 1999). 


\section{CAPÍTULO5}

\section{CONSIDERAÇÕES FINAIS}

$\mathrm{O}$ desenho e os recursos metodológicos empregados nessa pesquisa mostraram-se pertinentes aos objetivos do trabalho e permitem reafirmar, aqui, a importância de buscar nas pesquisas em qualidade de vida, estratégias metodológicas que possibilitem o conhecimento amplo da realidade e dados de caráter qualitativo. Destaque especial merece ser dado ao processo investigativo, no que se refere aos aspectos das relações sociais no trabalho, pois os dados do questionário WHOQOL/Breve mostram que professores e professoras, em geral, encontram-se satisfeitos com as suas relações sociais - incluindo-se aquelas do trabalho. Entretanto, os dados de observação e do grupo focal permitem aprofundar a investigação e evidenciam descontentamentos e insatisfações importantes (principalmente com os aspectos relacionais, sociais e da organização do trabalho docente); complementando as informações e enriquecendo o processo de construção do conhecimento.

Um outro ponto que merece ainda ser destacado, a respeito da questão metodológica, é a opção pela realização do grupo focal como uma possibilidade de oferecer aos sujeitos participantes da pesquisa, uma oportunidade de reflexão, diálogo, discussão, informação, conscientização e de trocas de experiências num processo de construção coletivo do saber que não deixa, inclusive, de exercer, também, uma função terapêutica; reafirmando, assim, o caráter pedagógico e transformador de propostas desse tipo, em consonância com a perspectiva da promoção da saúde.

A Qualidade de Vida (QV), avaliada pelo questionário WHOQOL/Breve, apresenta um escore médio de 66, valor que pode ser considerado regular.

Dentre os aspectos da Qualidade de Vida mais preservados encontram-se a satisfação com a capacidade de locomoção; a ausência de dor fisica; a capacidade de atribuir sentido à 
vida (que funciona como fator de resiliência e suporte emocional); o fato de não depender de tratamento médico para viver a vida cotidiana e as condições de moradia do professor.

Nos aspectos mais comprometidos estão as condições, o ambiente e o processo de trabalho docente (principalmente no que se refere aos aspectos sociais, relacionais e da organização ); as condições salariais insuficientes para as necessidades cotidianas; o desgaste intenso de energia física e psíquica associado ao sono e ao descanso insuficientes e à falta de oportunidades e de recursos econômicos para investimento pessoal, lazer e diversão, assim como de condições e de energia para vivenciar as experiências de lazer com prazer. Esses aspectos têm implicações negativàs no bem-estar pessoal, na vida privada - na interação familiar e social -, na saúde geral e vocal, e no trabalho profissional, contribuindo para o estresse fisico e mental.

O impacto da voz sobre a qualidade de vida, avaliado pelo questionário QVV (Qualidade de Vida relacionada à Voz), apresenta um escore médio no valor de 80, o que pode ser considerado bom, uma vez que o maior valor é 100 .

A investigação da Qualidade de Vida relacionada à Voz (QVV) possibilita identificar questões e necessidades de saúde vocal no contexto da docência. Os dados evidenciam que $39 \%$ dos professores avaliaram suas vozes como razoável ou ruim; $28,2 \%$ deles não sabem como a voz vai sair quando começam a falar, e 60,9\% dos professores têm necessidade de exploração e desenvolvimento da intensidade e projeção vocal, resistência vocal e coordenação pneumofonoarticulatória, devido à demanda para falar em ambientes ruidosos. Isso indica necessidades de desenvolvimento vocal e prejuízos na qualidade vocal, sugerindo a presença de disfonia nesse grupo de docentes, o que requer ações coordenadas de promoção da saúde vocal.

A inter-relação das questões e problemáticas de qualidade de vida e voz é confirmada pela correlação positiva e significativa entre o domínio Global do QVV e os domínios Psicológico, Físico, Meio ambiente e Relações sociais, do WHOQOL/Breve; configura-se também assim entre a auto-avaliação vocal dos professores e os domínios Global do QVV e Físico, Meio ambiente, Psicológico e Relações sociais do WHOQOL/Breve. 
Apreende-se que a saúde vocal se relaciona com a qualidade de vida em geral, especialmente nos aspectos que se referem à sensação de ter energia e capacidade para enfrentar o dia-a-dia; ao grau de satisfação com a saúde, consigo mesmo e com sua aparência física; ao grau de satisfação com o local de moradia e com as relações, salubridade e condições no trabalho.

Nota-se que quanto pior auto-avaliada for a voz, pior e mais negativo é o impacto da mesma sobre a qualidade de vida do sujeito; piores se encontram suas dificuldades para falar e realizar coordenação pneumofonoarticulatória; maiores são seus problemas expressivos, comunicativos ou profissionais relacionados à voz, e piores estão seus sentimentos negativos como frustração e depressão - o inverso sendo também verdadeiro. Nesse sentido, a questão isolada do QVV (como o sujeito avalia a própria voz) desponta como recurso a ser empregado nas ações coletivas de saúde vocal, como um processo preliminar às tradicionais triagens vocais de professores, e como possibilidade de agilizar a intervenção fonoaudiológica, no contexto de propostas como as de Escolas Promotoras de Saúde.

A maioria dos sujeitos lecionam em 2 ou 3 periodos, realidade que pode predispor a uma maior interferência do trabalho sobre a qualidade de vida e a saúde. Os sujeitos vivenciam, em seu cotidiano, sentimentos negativos como cansaço, desânimo, esgotamento e depressão (que não contribuem para uma produção vocal saudável); entretanto, encontram forças para não se deixarem abater - ainda que o sentimento de felicidade não ocorra freqüentemente. Evidencia-se a necessidade de que a atenção e promoção da saúde do trabalhador professor venham a englobar ações que contribuam para a reposição das energias física, psíquica e emocional despendidas no trabalho docente.

Nesta pesquisa, diversos aspectos de subjetividade e de qualidade de vida de professores e professoras de Ensino Médio puderam ser evidenciados e analisados, em suas possíveis relações com a saúde, com o uso profissional da voz na docência e com o processo saúde/doença vocal do trabalhador docente.

A saúde geral de professores encontra-se comprometida, com sofrimentos de ordem fisica e emocional variados e problemas e necessidades de saúde geral e vocal não resolvidos, 
não satisfeitas ou não atendidas. Os sujeitos sofrem a influência negativa dos problemas de saúde física e emocional na sua vida social; entretanto, o impacto das condições de saúde sobre a vida social é ainda pouco percebido e valorizado, uma vez que, mesmo experimentando o impacto negativo dos problemas de saúde sobre a vida social, os professores não chegam a se sentir insatisfeitos com as suas condições de saúde. Isso sugere que a dimensão social da vida humana merece ser melhor valorizada, lembrando que é justamente nessa dimensão que a voz e a linguagem encontram lugar, tomam corpo e fazem sentido.

Os sujeitos demonstram enfrentar dificuldades em perceber o próprio processo saúdedoença vocal; em perceber e valorizar sinais e sintomas vocais tais como instabilidade fonatória e variações da qualidade vocal; em perceber o impacto sócio-emocional da voz; como indicativos de comprometimento da saúde vocal, além de dificuldades em considerar a saúde vocal como componente da saúde geral. Evidencia-se uma "restrição" na autopercepção da relação sujeito-voz-relação social; especialmente quando o referencial é o parâmetro fonoaudiológico, que insere um conhecimento diferenciado da maioria da população - uma vez que a voz se refere a um dos objetos de trabalho da Fonoaudiologia e que esta área atribui grande valoração à voz e suas questões.

Essa "restrição" da auto-percepção vocal dos sujeitos deve, aqui, ser interpretada mais como uma diferença de conhecimento, valoração e de significação atribuídos à voz; diferença essa que sugere a necessidade de reflexão de ambas as áreas (Fonoaudiologia e Educação), sobre os usos e funções da voz no cotidiano, com abertura para uma re-significação da voz e re-interpretação dos aspectos que interferem na produção da voz/linguagem e no processo saúde-doença vocal.

O processo saúde-doença vocal docente é interpretado pelos sujeitos, a partir de uma representação relacionada à presença de alterações orgânicas na laringe, como os nódulos vocais e o câncer de laringe; além de freqüentemente associada a sentimentos negativos que assustam e terrificam o professor. Tais representações podem configurar, algumas vezes, fator de intimidação à iniciativa de buscar uma orientação especializada ou uma avaliação vocal, nos estágios iniciais de aparecimento de um problema de saúde vocal. Esse dado aponta perspectivas de investigação de caráter qualitativo, acerca das representações que permeiam as 
relações que os sujeitos estabelecem com sua voz/saúde vocal/processo saúde-doença vocal e sugere a necessidade da Fonoaudiologia reavaliar os focos que têm sido dados nas ações de saúde vocal docente, no sentido de evitar que se recaia no enfoque patológico e organicista que vem reforçando tais representações.

As transformações possíveis no campo da promoção da saúde vocal docente devem passar, necessariamente, por processos de conhecimento, discussão, reflexão e de mudanças nos referenciais simbólicos e nos processos subjetivos e intersubjetivos que determinam e mantém as representações e concepções a partir das quais tomam sentido as funções da voz nos contextos sociais cotidianos, as necessidades de saúde e o próprio processo saúde-doença docente.

$\mathrm{Na}$ organização do trabalho docente, a afetividade entre professor e aluno exerce papel dúbio no processo de adesão e da resistência ao trabalho, pois implica a vivência de sentimentos de angústia e sofrimento variados que decorrem das diferenças entre vinculações idealizadas e as formas como a afetividade é vivenciada, num contexto social que envolve posturas autoritárias e controladoras, e no qual as comunicações são estabelecidas com esforço, conflitos e agressividades - muito diferente do que seria esperado de uma Escola Promotora de Saúde..

Evidenciam-se, ainda, dificuldades dos sujeitos em caracterizarem seu papel, função e identidade profissional - uma vez que os professores continuam vendo, na escola, a extensão de suas próprias casas, seus próprios lares e, nos alunos, a extensão da própria família. Isso tudo implica problemas a constituição da subjetividade, na identidade e nos modos de ser do professor, com repercussões que afetam, inclusive, os modos de uso da voz no trabalho docente. As dificuldades com a caracterização do papel docente envolvem, ainda, as representações e concepções de processo ensino-aprendizagem que orientam a ação docente, em que concorrem ideários distintos (democrático-participativos e centralizadorestradicionais) os quais dificultam e obscurecem as representações acerca dos papéis e posicionamentos dos sujeitos envolvidos. 
Nesse contexto, observa-se que professores tendem a assumir posições paternalistas/maternalistas, que reafirmam a relação de dependência dos alunos (percebidos a partir de representações depreciativas, como incapazes, acomodados, desinteressados, dependentes e sem iniciativa) e confirmam a assimetria professor-alunos, ao mesmo tempo em que impedem a superação dessa assimetria. Impera, ainda, o roteiro de aula expositiva, tradicional, que requer intensa demanda vocal docente. Evidenciam-se, dessa maneira, necessidades como de reflexão e de buscar encontrar estratégias que possibilitem ao professor olhar e enxergar seu aluno real, de maneira a procurar formas eficazes de com ele relacionarse e comunicar-se; assim como que ofereçam subsídios para o aclarar e fortalecer das concepções de processo ensino-aprendizagem que orientam a prática, no sentido de contribuir para a constituição da subjetividade docente e discente.

A organização do trabalho docente envolve, também, questões importantes da relação social entre docente e administração/coordenação. Nessa relação, observa-se que professores e professoras sentem-se excluídos de processos decisórios e que têm suas funções tutoradas, controladas, disciplinadas e reguladas num contexto de uma rede complexa de relações hierárquicas autoritárias em que imperam conflitos de interesses e poderes que incomodam os docentes, atingindo diretamente sua subjetividade, seu ato educativo e sua saúde. Evidencia-se a falta de oportunidades de reflexão e discussão, da comunidade escolar, a respeito das formas como tais relações estão sendo são construídas e estruturadas pelos atores sociais dessas escolas. Isso sinaliza necessidades de investimento na melhoria da qualidade das comunicações e das relações profissionais nessas instituições, campo para o qual a Fonoaudiologia, em parceria com a Psicologia, certamente traria grandes contribuições, na medida em que essas especialidades venham a compor a equipe que viabilize uma proposta de Escolas Promotoras de Saúde nesses equipamentos sociais.

Vale destacar que as caracteristicas apresentadas pelas escolas dessa pesquisa mostram-se contrárias àquelas desejadas numa Escola Promotora de Saúde; seja em seus aspectos físicos, ambientais, sociais ou da organização do trabalho docente. As percepções que eu pude ter, durante a primeira fase dessa pesquisa, indicam diferenças significativas entre as 4 escolas visitadas, sendo a pior impressão a causada pela Escola 1. Causa estranhamento e incômodo o fato de que os problemas de ordem comunicativa, social e relacional, tão 
evidentes naquela escola, sejam deixados à margem de um processo de reflexão e de discussão e que, por isso mesmo, estejam sendo mantidos intocados e longe da possibilidade de transformação.

As especificidades de cada escola, apontadas nesse trabalho, reafirmam a necessidade da realização de um diagnóstico institucional ou avaliação diagnóstica para o conhecimento da realidade do trabalho docente em cada escola em que o fonoaudiólogo se proponha a atuar. Esse momento inicial deve envolver todos os atores sociais da comunidade escolar e dar voz às suas necessidades e expectativas a fím de que, juntamente com o fonoaudiólogo e demais profissionais da saúde, a comunidade escolar venha a participar de um processo de construção coletiva de uma proposta de Promoção da Saúde compatível com a formação de ambientes saudáveis, como deve ser a de uma Escola Promotora de Saúde.

Ficam claros os efeitos sociais do trabalho sobre o professor, sua família, seu tempo livre e seus modos de usufruir a vida privada. Assim é que os sujeitos observam a restrição do seu tempo de convívio e da qualidade das relações familiares, sociais e das oportunidades de desfrutar, com prazer, dos momentos de lazer, muitas vezes em função da fadiga e do cansaço (inclusive vocal). İsso sugere que se discutam as relações entre trabalho e vida privada, nas propostas de promoção da saúde vocal docente.

Nesse estudo, $69,5 \%$ dos sujeitos são do sexo feminino, sinalizando a importância de que as profissões da saúde que se proponham a atuar junto à promoção da saúde do trabalhador docente passem a incluir, em seus temas de estudo e formação profissional, as temáticas e questões de gênero - uma vez que elas encontram-se na origem da identidade e carreira docente e que ainda se fazem presentes no cotidiano de vida e trabalho da mulher/trabalhadora/professora.

Os Professores constroem um ideário de uma produção vocal saudável demonstrando ter consciência da importância da voz no trabalho docente e possuírem conhecimento básico das noções de higiene e da saúde vocal, assim como das condições ótimas para o uso adequado da voz. Entretanto, a realidade do cotidiano engloba diversos aspectos que não se restringem ao espaço da sala de aula, mas que envolvem questões sociais, estruturais e da 
organização do trabalho docente, os quais se interpõem e inviabilizam a conquista desse ideário. Assim é que os contextos sociais reais de uso da voz se apresentam, no cotidiano de trabalho e de vida privada, de maneira a levar o docente a usar a sua voz de forma distinta daquela chamada "voz higiênica".

Nesse sentido, destaca-se a necessidade de que fonoaudiólogos se voltem ao conhecimento e à investigação dos contextos sociais cotidianos em que se dão o uso da voz e onde se constrói o processo saúde - doença vocal docente. É imprescindivel valorizar a qualidade, os usos, as funções e a saúde da voz dos sujeitos nos contextos sociais de vida privada (incluindo-se, aí, os contextos familiares, comunitários, de lazer e diversão do professor) na integridade do sujeito e da sua vida, indo além da perspectiva da prevenção da patologia ou do uso profissional da voz.

Essa pesquisa evidencia a correlação entre qualidade de vida, trabalho, subjetividade e saúde - geral e vocal - confirmando a necessidade de propostas de caráter amplo e abrangente na promoção da saúde vocal do professor, com ações de característica processual e enfoque de caráter inter e transdisciplinar que dêem conta da complexidade das comunicações, interações sociais, das subjetividades e dos aspectos do cotidiano de vida, e da qualidade de vida dos sujeitos envolvidos. Levariam, também, a possibilidades no sentido da afirmação da Fonoaudiologia na perspectiva da Promoção da Saúde e formação de ambientes saudáveis, especialmente na proposta de Escolas Promotoras de Saúde. 


\section{BIBLIOGRAFIA}

Abel, M. e Sewell, J. Stress and burnout in rural and urban secondary school teachers. Journal Education Research, may-jun vol. 92(5). Heldref Publications, 1999.

Abbud, LE. SF36 e VHI: Avaliando o impacto da disfonia no dia-a-dia de professoras do Ensino Fundamental da Rede Pública e Particular. Relatório Final de Iniciação Científica. São Paulo, PUC/SP, 2001.

Algodoal, MJ.A.O. As Práticas de Linguagem em Situação de Trabalho de Operadores de Telemarketing Ativo de uma Editora. (Tese de Doutorado). São Paulo, PUC/SP - LAEL, 2002.

Alves, R. O preparo do educador. In: Brandão, C.R. (Org)-Educador: vida e morte. Rio de Janeiro, Ed. Graal $11^{\star}$ ed., 1998. p. 15-28.

Andrade, E.C. Pesquisa de alterações vocais em professores de $1^{\prime}$ e $4^{\circ}$ séries do $1^{\circ}$ grau da rede municipal de ensino de Belo Horizonte. Revista de Fonoaudiologia. Ano 1, 1: 24-29, maio/out. 1994.

André, L.M. A técnica de entrevista individual. Disciplina HSP 5726, São Paulo, FSP/USP, 1997. Mimeo.

Araújo, M.D. Formação de recursos humanos para a área de saúde do trabalhador. In: Borges, L.H., Moulin, M.G.B. e Araújo, M.D. (Orgs) - Organização do trabalho e saúde. Vitória, CCHN Publicações e EDUFES, 2001. pp. 373-388.

Arroyo, M.; Diniz, M.L.; Garcia, D.F.; Oliveira, Z.F. e Viana, F.M. Subsidios para a práxis educativa da supervisão educacional. In: Brandão, C.R. (Org) - Educador: vida e morte. Rio de Janeiro, Ed. Graal $11^{*}$ ed., 1998. pp. 103-133.

Assunção, M.M.S Magistério primário e cotidiano escolar. Campinas, Autores Associados, 1996.

Bakhtin, M. Marxismo e filosofia da linguagem. $6^{\circ}$ ed, São Paulo, Ed. Hucitec, 1992.

Bardin, L. Análise de conteúdo. Lisboa, Edições 70, 1977.

Bardou De Carvalho, MM. O professor - um profissional, sua saúde e a educação em saúde na escola. Tese de doutorado. São Paulo, Faculdade de Saúde Pública FSP/USP, 1995.

Barros, R.D.B. Grupo: estratégia na formação. In: Brito, J.; Barros, M.E.; Neves, M. e Athayde, M. - Trabalhar na escola? Só inventando o prazer. Rio de Janeiro, IPUB-CUCA, 2001. pp.71-88. 
Batista, A.S. e Codo, W. Crise de identidade e sofrimento. In: Codo, W. (Coord.)Educação: carinho e trabalho. $2^{\text {a }}$ ed., Petrópolis/Vozes e Brasília/Conf. Nac. dos Trab. em Educação, 2000. pp. 60-85.

Behlau, M.- Presbifonia: envelhecimento vocal inerente à idade. In: Russo, IP. Intervenção fonoaudiológica na terceira idade. Rio de Janeiro, Ed. Revinter, 1999. pp. 25-50.

Behlau, M. Qualidade de vida e voz - um estudo brasileiro. Anais: LX Congresso Brasileiro de Fonoaudiologia, Guarapari (ES), 26 a 30 de setembro de 2001-a.

Behlau, M. (Org) Voz - o livro do especialista. Rio de Janeiro, Revinter, 2001-b.

Behlau, M Vozes preferidas: considerações sobre opções vocais nas profissões. Revista ono Atual, 4 (16), São Paulo, 2001-c.

Behlau, M; Andrade, D.; Madazio, G. e Rehder, M.I. Voz profissional: aspectos gerais e atuação fonoaudiológica. Apostila 8 - São Paulo, CECEV Centro de Estudos da Voz, 1999 (mimeo/apostila).

Behlau, M; Madazio, G; Feijó, D. e Pontes, P. Avaliação de voz. In: Behlau, M. „. - Voz: o livro do especialista. Rio de Janeiro, Revinter, 2001. p.85-245.

Behlau, M. e Pontes, P Princípios de reabilitação vocal nas disfonias. São Paulo, EPPM. 2 * ed. Revisada e ampliada, 1990.

Behlau, M; Azevedo, R. e Pontes, P Conceito de voz normal e classificação das disfonias. In: Behlau, M (Org.)-Voz: o livro do especialista vol.1. Rio de Janeiro, Revinter, 2001. pp. 53-84

Behlau, M. e Pontes, P. Avaliação e tratamentos das disfonias. Ed. Lovise, São Paulo, 1995.

Behlau, M. e Pontes, P. Higiene vocal: cuidando da voz. $2^{\mathrm{a}}$ ed. Rio de Janeiro, Revinter, 1999.

Berberian, A.P. Fonoaudiologia e educação - um encontro histórico. São Paulo, Ed. Plexus, 1995.

Berlinguer, G. A relação entre saúde e trabalho do ponto de vista bioético. Revista Saíde $e$ Sociedade 2(2). São Paulo, APSP/USP, 1993. pp.101-134.

Betancourt, O. e Palacios, M. Trabajo y salud en el magisterio del Ecuador. Salud de los trabajadores. Vol.7 n. ${ }^{\circ}$ 2. Univ. de Carabobo, Venezuela, 1999. pp.111-121.

Boltanski, L. As classes sociais e o corpo. $2^{\text {a }}$ ed.. Rio de Janeiro, Edições Graal, 1984.

Boone, D.R e Mcfarlane, S.C. - A voz e a terapia vocal. Trad. de Costa, S. Porto Alegre, Artes médicas, 1994. 
Borges, L.H - As lesões por esforços repetitivos como índice do mal-estar no mundo do trabalho. In: Borges, L.H., Moulin, M.G.B. e Araújo, M.D. (Orgs) Organização do trabalho e saúde. Vitória, CCHN Publicações e EDUFES, 2001. pp. 157-174

Brandão, H.H.N. Introdução à análise do discurso. Campinas, Ed. da Unicamp, 1996.

Brant, L.C. e Barros De Melo, M. Promoção da saúde e trabalho: um desafío teórico e metodológico para a saúde do trabalhador. Saúde em Debate v. $25 \mathrm{n}^{\circ} 57$. Rio de Janeiro, 2001. pp.55-62.

Brito, J. C. Saude, trabalho e modos sexuados de viver. Rio de Janeiro, Editora Fiocruz, 1999.

Brito, J.C. Enfoque de gênero e relação saúde/trabalho no contexto de reestruturação produtiva e precarização do trabalho. Cadernos de Saúde Pública vol. $16 \mathrm{n}^{\circ} 1$, . Rio de Janeiro 2000.

Brito, J.C. e D'acri, V. Referencial de análise para o estudo da relação trabalho, mulher e saúde. Cadernos de Saúde Pública 7(2): 190-200, Rio de Janeiro, 1991.

Brito, J. et al. La faz oculta de la escuela pública en Brasil. Salud y trabajo de coceneras y ayudantes. Salud de los trabajadores. Vol.7 n. 2 . Venezuela, Univ. de Carabobo, 1999. pp. 89-99.

Brito, J.; Athayde, M; Hyppolito, B.N.; Silva; E.F.; Santos, M.B. e Santos Filho, A. Readaptação profissional: a ponta do iceberg? In: Brito, J.; Barros, M.E.; Neves, M. e Athayde, M. Trabalhar na escola? Só inventando o prazer. Rio de Janeiro, IPUB-CUCA, 2001. pp. 163-183.

Buss, P.M. Promoção da saúde e qualidade de vida. Revista Ciência e Saúde Coletiva, $\mathrm{n}^{\circ} 5$ v.1. Abrasco, 2000.

Calvete, E. e Villa, A. Burnout y sontomas psicologicos: modelo de medida y relaciones estructurales. Ansiedad-y-estres, vol. 6(1), 2000.

Campos, H. Estatística Experimental Não-Paramétrica. $4 .^{a}$ ed. Piracicaba, FEALQ, 1983.

Campos, E.P.A doença como expressão do processo de socialização. Revista Brasileira de Medicina Psicossomática. Vol.1 n², 1997. pp. 92-96.

Carelli, E.G. Educação vocal na formação do docente. Monografia de Especialização em Saúde Pública. Campo Grande (MS), Escola de Saúde Pública Dr. Jorge David Nasser/ENSPFIOCRUZ, 2002.

Carlini-Cotrim, B. Potencialidades da técnica qualitativa grupo focal em investigações sobre abuso de substâncias. São Paulo, Revista de Saúde Pública, 30 (3): 285-93, 1996. 
Cameiro, M.C.B.G. de C. Um estudo de morbidade entre professores no municipio de Rio Claro (S.P.). Monografia de Licenciatura em Pedagogia. Rio Claro, Instituto de Biociências/UNESP, Departamento de Educação, 1997.

Cameiro, M.C.B.G. de C. A saúde do trabalhador professor. Dissertação de Mestrado. São Carlos, Universidade Federal de São Carlos - UFSCAR, 2000.

Cavalheiro, M. T.Trajetória e possibilidades de atuação do fonoaudiólogo na escola. In: Lagrotta, M. e César, C. A fonoaudiologia nas instituições. São Paulo, Ed. Lovise, 1997.

CFFA - SP aprova lei sobre saúde vocal do professor. Jornal do Conselho Federal de Fonoaudiologia.Ano VI n ${ }^{\circ} 11$. Brasília, 2001. p.17

Chernoff, H. Use of Faces to Represent Points in K-dimensional Space Graphically. Journal of the American Association, vol.68, n 342, pp.361-368, 1973.

Chun, R.Y.S. A Voz na interação verbal: como a interação transforma a voz. Tese de Doutorado. São Paulo, Pontificia Universidade Católica - PUC/SP, 2000.

Chun, R.Y.S. A Voz na interação verbal: como a interação transforma a voz. Anais: IX Congresso Brasileiro de Fonoaudiologia, Guarapari (ES), 26 a 30 de set. de 2001. Trab. 648.

Chun, R.Y.S. Grupos de voz profissional: repensando práticas e conceitos na promoção da saúde vocal. Anais: IX Congresso Brasileiro de Fonoaudiologia, Guarapari (ES), setembro/2001-b. Trab. 101.

Chun, R.Y.S. Voz profissional: repensando conceitos e práticas na promoção da saúde vocal. In: FERREIRA, L.P. e SILVA, M.A.A. - Saúde vocal - práticas fonoaudiológicas. São Paulo, Ed. Roca, 2002. pp. 19-32

Chun, R.Y.S. e Navarro, C. Voz profissional - a formação acadêmica. In: LACERDA, C.B.F. e PANHOCA, I. - Tempo de Fonoaudiologia II. Ed. Cabral Universidade Taubaté, 1998.

Cocco, M.I.M. Práticas educativas em saúde e a construção do conhecimento emancipatório. In: Bagnato, M.H.S.; Cocco, M.IM. E de Sordi, M.R.L. (Orgs) - Educação, saúde e trabalho - antigos problemas, novos contextos e outros olhares. Ed. Alínea, Campinas, 1999-a. pp. 6370.

Cocco, M.I.M- Trabalho e educação- novas possibilidades para velhos problemas. In: Bagnato, M.H.S.; Cocco, M.I.M. e De Sordi, M.R.L. (Orgs) - Educação, saúde e trabalho antigos problemas, novos contextos e outros olhares. Ed. Alínea, Campinas, 1999-b. pp. 99110.

Cochran, W.G. Técnicas de Amostragem. Rio de Janeiro: John Wiley e Sons, Inc., 1965.

Codo, W. Educação: carinho e trabalho. Petrópolis/Vozes e Brasília/Conf. Nac. dos Trab. De Educação, $2^{\text {a }}$ ed., 2000. 
Codo, W. e Batista, A.S. O outro como produto. In: Codo, W. (Coord.)- Educacăo: cartm: e trabalho. 2 ed., Petrópolis/Vozes e Brasília/Conf. Nac. dos Trab. em Educação, 2000. pp. 384-389.

Codo, W. e Gazzotti, A.A Trabalho e afetividade. In: Codo, W. - Educação: carinho e trabalho. $2^{\text {a }}$ ed., Petrópolis/Vozes e Brasília/Conf. Nac. dos Trab. em Educação, 2000. pp. 48-59.

Codo, W. e Vasques-Menezes, I. Educar, educador. In: Codo, W. - Codo, W. - Educação: carinho e trabalho. $2^{a}$ ed., Petrópolis/Vozes e Brasília/Conf. Nac. dos Trab. em Educação, 2000-a. pp. $37-47$.

Codo, W. e Vasques-Menezes, I. O que é burnout? In: Codo, W. - Codo, W. - Educação: carinho e trabalho. $2^{a}$ ed., Petrópolis/Vozes e Brasília/Conf. Nac. dos Trab. em Educação, 2000-b. pp.237-254.

Coelho, I.M. A questão política do trabalho pedagógico. In: Brandão, C.R. (Org) Educador: vida e morte. $11^{*}$ ed., Rio de Janeiro, Ed. Graal 1998. pp. 31-49.

Coelho, M.A; Behlau, M. e Vasconcellos, E.G. Da relação entre stress e distúrbios da voz. In: Marchesan, I; Zorzi, J.; Gomes, I- Tópicos em fonoaudiologia v. III. São Paulo, Lovise, 1996.. pp. 361-388.

Coelho, M.A. e Vasconcellos, E.G. Falar sob stress - considerações preliminares sobre as variações vocais e psicofisiológicas em repórteres em uma situação de entrada ao vivo. In: Kyrillos, L.R. - Fonoaudilogia e telejornalismo. Rio de Janeiro, Revinter, 2003. pp. 61-70.

Cohn, A. e Marsiglia, R.G. - Processo e organização do trabalho. In: Rocha, L.E.; Rigotto, R.M. e Buschinelli, J.T.P. (Orgs) Isto é trabalho de gente? Vida, doença e trabalho no Brasil. Petrópolis, Ed. Vozes, 1994. pp. 57-75.

Colbari, A. Resistência e adesão no universo das relações de trabalho. In: Borges, L.H., Moulin, M.G.B. e Araújo, M.D. (Orgs) Organização do trabalho e saúde. Vitória, CCHN Publicações e EDUFES, 2001. pp. 113-31

Colton, R.H. e Casper, J.K. Compreendendo os problemas de voz - uma perspectiva fisiológica ao diagnóstico e ao tratamento. Porto Alegre, Artes Médicas, 1996.

Costa Neto, P.L.O. Estatística. São Paulo, Edgard Blücher, 1977.

Couto, H.A. Fadiga psíquica - resultados da aplicação de um método alternativo para identificação dos agentes etiológicos ligados ao ambiente de trabalho. São Paulo, Revista Brasileira de Saúde Ocupacional, 1981. pp.16-24

Cragno, R.C. Higiene vocal en el futuro docente. Revista Fonoaudiológica. Tomo $38, \mathrm{n}^{\circ} 3$. Buenos Aires, 1992. pp. 60-74. 
Crespo, A.A. Estatística Fácil. São Paulo, Editora Saraiva, 1991.

CRFA. $2^{2}$ Região. Semana da voz. Informativo do Conselho Regional de Fonoaudiologia/SP, $n^{\circ} 38 \mathrm{jan} / \mathrm{mar} ; 2001-\mathrm{a}$.

CRFA. 2 Região. Problemas vocais em professores causam cem milhões de reais em prejuízos. Informativo do Conselho Regional de Fonoaudiologia/SP, n 39 abril/maio; 2001-b

CRFA. $2^{2}$ Região. Voz profissional abre mercado de trabalho aos fonoaudiólogos. Informativo do Conselho Regional de Fonoaudiologia/SP, n 38 jan/mar; 2001-c.

CRFA. $2^{2}$ Região. Aprovada a lei sobre saúde vocal do professor. Informativo do Conselho Regional de Fonoaudiologia/SP n ${ }^{\circ} 42$, nov/dez; 2001-d. p.14.

CRFA. 2 Região.Lei cria programa de orientação fonoaudiológica em escolas de Santos. Informativo do Conselho Regional de Fonoaudiologia/SP n 49, jan/fev/mar 2003. P.6.

Cruz Neto, O. O trabalho de campo como descoberta e criação. In: Minayo, M.C.S. (Org) Pesquisa social - teoria, método e criatividade. $7^{2}$ ed , Petrópolis R. J., . Ed. Vozes, 1997.

Cunha, M.I. Trabalho docente e ensino superior. In: Rays, O.A. (Org) - Trabalho pedagógico: realidades e perspectivas. Porto Alegre, Ed. Sulina, 1999. pp. 213-225.

Daniel, J. e Schuller, I. Burnout in teacher's profession: age, years of practice and some disorders. Studia-psychologica, vol. 42 (1-2), 2000.

Declaração De Adamantina Documento da III Conferência Brasileira de Comunicação e Saude. Adamantina (SP), 6 a 8 de novembro de 2000.

De Souza, M.F.M. e Kalichman, A.O. Vigilância à saúde: epidemiologia, serviços e qualidade de vida. In: De Souza, M.F.M; Kalichman, A.O.; Matida, L.H; Komatsu, N. Vigilância à saúde: textos. São Paulo, Cadernos CEFOR, série textos 2, 1992.

Dias, A.E. e Hara, F. A qualidade de vida relacionada à voz na terceira idade. Anais: IX Congresso Brasileiro de Fonoaudiologia, Guarapari (ES), 26 a 30 de setembro de 2001. Trab. 551.

Dragone, M.L.O.S. Ocorrência de disfonia em professoras: fatores relacionados a voz profissonal. Monografia de especialização, CECEV, São Paulo, 1996.

Dragone, ML.O.S.; Sichirolli, S.; Reis, R; Behlau, M. O desgaste vocal do professor - um estudo longitudinal. Revista Sociedade Brasileira Fonoaudiologia 5 : 50-6; 1999.

Dragone, M.L.O.S. Voz do professor: interfaces e valor como instrumento de trabalho. Dissertação de Mestrado, Araraquara, Universidade Estadual de São Paulo- UNESP, 2000. 
Dragone, M.L.O.S. Novos caminhos para os estudos sobre a voz do professor. Revista Fonoaudiologia Brasil vol. $1 \mathrm{n}^{\circ}$ 1. Brasília, 2001. pp.43-50

EC/WHO-E/CE La Escuela Promotora de Salud - una inversion em educación, salud y democracia. Primeira Conferência de la Red Europea de Escuelas Promotoras de la Salud Resolucion de la conferência. Salónica-Halkidiki, Grécia, maio de 1997.

Estrela, M.T. Relação pedagógica, disciplina e indisciplina na aula. $2^{\mathrm{a}}$ ed., Porto, Portugal, Ed. Porto, 1994.

Fabiano, S.R.R. e Brasoloto, A. Efeitos acústicos do uso profissional da voz pelo professor. In: Behlau, M (Org) - Laringologia e voz hoje. Rio de Janeiro, Revinter, 1998. p.399

Fabron, E.M.; Sebastião, L.T. e Omote, S. Prevenção de distúrbios vocais em professores e crianças: proposta de intervenção junto a instituições educacionais. In: Ferreira, L.P. e Costa, H. - Voz ativa-falando sobre o profissional da voz. São Paulo, Rocca, 2000.

Fernandes, C.R.J. Caracterização de um grupo de professores com alteração vocal da préescola do municipio do Taboão da Serra. In: Ferreira, L.P. (Org) - Dissertando sobre voz Interfaces vol. 2. Carapicuíba, Pró-fono, 1998.

Ferreira, L.P. A avaliação da voz: o sentido poderia ser outro? In: Ferreira, L.P. (Org) - Um pouco de nós sobre voz. $3^{*}$ ed. Carapicuíba, Pró-Fono, 1994.

Ferreira, L.P. A voz do professor: propostas de ações coletivas de promoção de saúde vocal. In: Giroto, C.R.M. (Org) - Perspectivas atuais da fonoaudiologia na escola. São Paulo, Ed. Plexus, 1999-a. pp.72-88.

Ferreira, L.P. Voz profissional. São Paulo, anais do IV Congresso Internacional de Fonoaudiologia e III Encontro Ibero-Americano de Fonoaudiologia. SBFa, 1999-b. p. 500.

Ferreira, L.P. Voz e sistema sensório-motor oral: o problema dos objetos. In: Freire, M.R. (Org) - Fonoaudiologia- seminários de debates vol 3. São Paulo, Rocca, 2000.

Ferreira, L.P. A disfonia como doença do trabalho. Brasília, Jornal do Conselho Federal de Fonoaudiologia, jan/fev/mar. 2002. p. 18.

Ferreira, L.P; Algodoal, M.J. e Silva, M.A.A. - A avaliação da voz na visão (e no ouvido) do fonoaudiólogo: saber o que se procura para entender o que se acha. In: Marchesan, I.Q. et al Tópicos em fonoaudiologia - Vol. IV. São Paulo, Ed. Lovise, 1997/1998. pp.. 393-413.

Ferreira, L.P e Silva, M.A. Saúde vocal-práticas fonoaudiológicas. São Paulo, Roca, 2002.

Ferreira, L.; Silva, E.; Karmann, D.F.; Figueira, S. e Giannini, S.P.P. Saúde geral e vocal de professores da prefeitura municipal de São Paulo. Poster. Mostra realizada na Biblioteca PUC/SP, maio, 2002. 
Ferreira, L.; Giannini, S.P.P.; Figueira, S.; Silva, E.; Karmann, D.F. e Thomé-de-Souza, T. Condições de produção vocal de professores da prefeitura do município de São Paulo. Revista Distúrbios da Comunicação 14 (2), São Paulo, 2003. pp: 275-307.

Figueira, S. Pericia em voz. IX Congresso Brasileiro de Fonoaudiologia, Guarapari (ES), 26 a 30 de setembro de 2001 .

Figueiredo Neto, L. H. Consciência histórica e identidade profissional. Revista Distúrbios da Comunicação 7: 71-78, PUC/São Paulo, dez. 1994.

Fleck, M.P.A. O instrumento de avaliação de qualidade de vida da Organização Mundial da Saúde (WHOQOL-100): características e perspectivas. Revista Ciência e Saúde Coletiva, $\mathrm{n}^{\circ}$ 5 v. 1 . Abrasco, 2000.

Fleck, M. et al. Aplicação da versão em português do instrumento de avaliação de qualidade de vida da Organização Mundial da Saúde (WHOQOL-100). Ver. Saúde Pública, 33 (2),pp. 198-205, 1999.

Fleck, M. et al $O$ instrumento de avaliação de qualidade de vida abreviado da Organização Mundial da Saúde (WHOQOL/Breve): aplicação da versão em português. Revista de Saúde Pública 34 (2), 2000.

Flores, J.G. e Alonso, C.G. Using focus groups in educational research. Evaluation Review, feb. (1): 84-101, 1995.

Fontana, R.C. Trabalho e subjetividade- nos rituais da iniciação, a constituição do ser professora. Cadernos Cedes ano XX no 50. Unicamp, Campinas, 2000. pp. 103-119.

Foulcault, M. Vigiar e punir. Rio de Janeiro, Ed. Vozes, $12^{\mathrm{a}}$ edição, 1995.

Franchi, C. Linguagem-atividade constitutiva. Almanaque/ cadernos de literatura e ensaio, $\mathrm{n}^{\circ}$ 5. Ed. Brasiliense, São Paulo, 1977.

França, A.C.L. e Rodrigues, A.L. Stress e trabalho. São Paulo, Atlas, $2^{\star}$ ed., 1999.

Freire, P. Educação como prática da liberdade. Rio de Janeiro, Paz e Terra, 1969.

Freire, P. - Extensão ou comunicação? $6^{\prime}$ ed. Trad. de Oliveira, R.D.. Rio de Janeiro, Paz e Terra, 1982.

Freire, P. e Schor, I. Medo e ousadia: o cotidiano do professor. $3^{*}$ ed. Trad. de Lopez, A. Rio de Janeiro, Paz e Terra, 1990.

Friedman . S. Uma aproximação metodológica no estudo das emoções. In: Lane, S.T.M. e Sawaia, B.B. (Orgs) - Novas veredas da psicologia social. Ed. Brasiliense/EDUC, São Paulo, 1994. 
Furlani, L.M.T. Autoridade do professor: meta, mito ou nada disso?, $6^{\circ}$ ed.,. São Paulo, Cortez2000.

Gadotti, M. Educação e poder-introdução à pedagoga do conflito, $7^{*}$ ed,. São Paulo, Cortez e Autores Associados,., 1987.

Gallo, S. - (Coord.) Ética e cidadania-caminhos da filosofia. Unid. 6 - O corpo. Campinas, Papirus, 1997. pp. 61-68.

Garcia, R. A. S. Operadores de Telemarketing: Os Múltiplos Sentidos da Voz. (Dissertação de Mestrado). PU'C/SP, 2000.

Garcia, R.A.S. e Ferreira, L.P. Operadores de telemarketing: os múltiplos sentidos da voz. Anais: IX Congresso Brasileiro de Fonoaudiologia, Guarapari, 2001, trab. 302.

Gayotto, M.L. Liderança de mudança e grupo operativo. Petrópolis, Ed. Vozes, 1985.

Geraldi, J.W. Portos de passagem, 4 ed., Ed. Martins Fontes, São Paulo, 1997.

Gião, P.H.A. et al. Voz e estresse ocupacional em professores universitários. Anais do IV Congresso Internacional de Fonoaudiologia e III Encontro Ibero-Americano de Fonoaudiologia. SBFa. São Paulo, 1999. p.120.

Gobbi, F.A. A construção do objeto voz na produção acadêmica da PUC-SP: considerações sobre uma nova agenda de teorização e pesquisa. (Trabalho de Conclusão de Curso). Faculdade de Fonoaudiologia, PUC/SP, 2000.

Gonçalves, D.C. O discurso sobre as relações educação-saúde-trabalho de professores universitários e trabalhadores da construção civil. Dissertação de Mestrado. Florianópolis, Universidade Federal de Santa Catarina, 1996.

Gotaas, C. e Starr, C. Vocal fatigue among teachers. Folia foniatrica 45, 1993. pp. 120-9.

Grillo, M.H.M.M. A voz do professor universitário: impacto de um curso de aperfeiçoamento vocal em contexto de prevenção fonoaudiológica. Dissertação de Mestrado. São Carlos, Universidade Federal de São Carlos UFSCAR, 2001.

Grillo, M.H.M.M. Proposta de aperfeiçoamento vocal para professores. In: Ferreira, L.P. e Silva, M.A.A. - Saúde vocal - práticas fonoaudiológicas. São Paulo, Ed. Roca, 2002. pp. 207-228.

GRUPO WHOQOL Instrumentos de avaliação de qualidade de vida (WHOQOL) - Projeto desenvolvido no Brasil pelo grupo de estudos em qualidade de vida. Coordenação Dr. Fleck, M.P.A. Departamento de Psiquiatria e Medicina Legal. Universidade Federal do Rio grande do Sul, 1998. 
Guareschi, P. e Jovchelovitch, S. (Orgs) Textos em representações sociais. $6^{\mathrm{a}}$ ed. Petrópolis, Vozes, 2000.

Guazzelli, LR.B. Construindo novas formas de subjetividade e de cidadania. Tese de Doutorado. São Paulo, Pontificia Universidade Católica/PUCSP, 1999.

Guzzoni, M.A. A autoridade na relação educativa. São Paulo, Annablume, 1995.

Heckert, A.L; Aragão, E.; Barros, M.E. e Oliveira, S. A dimensão coletiva da saúde: uma análise das articulações entre gestão administrativa e saúde dos docentes - a experiência de Vitória. In: Brito, J.; Barros, M.E.; Neves, M. e Athayde, M. - Trabalhar na escola? Só inventando o prazer. Rio de Janeiro, IPUB-CUCA, 2001. pp. 123-162.

Helman, C.G. Cultura, saúde e doença. Trad. Mussnich, E. Pơtto Alegre, Artes Médicas, 1994.

Hoaglin, D.C.; Mosteller, F.; Tukey, J.W. Análise Exploratória de Dados. Técnicas Robustas, Trad. Ed. Salamandra, Coleção Novas Tecnologias, Lisboa, 1991, 446p.

Hogikyan, N.D. e Sethuraman, G. Validation of an instrument to measure voice-related quality of life. J. Voice, 13:557-69, 1999.

Hoppe, M. J. et al. Using focus groups to discuss sensitive topics with children. Evaluation Review, 19 (1): 102-14, 1995.

House, J.S. Work stress and social support. $2^{\mathrm{a}}$ impressão. Addison-Wesley Publishing Company, 1983.

Iervolino, S.A. Escola prömotora da saúde - um projeto de qualidade de vida. Dissertação de Mestrado. São Paulo, Faculdade de Saúde Pública - USP, 2000.

IstoÉ - Mestres sem carinho: violência, baixos salários, pressões e várias jornadas colocam os professores entre os profissionais mais entressados do país. Revista IstoÉ, edição n ${ }^{\circ} 1714$. São Paulo, Ed. Três, 2002.

Jacobson, B.H; Johnson, A; Grywalski, C; Silbergleit, A.; Jacobson, G; Benninger, M. e Newman, C. The voice handicap index (VHI): development and validation. Amer. J. Speech Lang. Pathol., 6: 66-70, 1997.

Janesick, V.J. The dance of qualitative research design: metaphos, methodolatry and meaning. In: Denzin, N.K. e Lincoln, Y.S. - Handbook of qualitative research. Sage, London, 1993.

Kickbusch, I. Promoción de la salud: una perspectiva mundial. In: OPAS / OMS Promoción de la salud: una antología. Washington, EUA, 1996.

Kohen, J.A.- Salud y trabajo docente, elementos teóricos-metodológicos de la investigación al monitoreo epidemiológico. Salud de los trabajadores. Vol.7 n. ${ }^{\circ}$. Univ. de Carabobo, Venezuela, 1999. pp 51-67. 
Kupfer, M.C.M Relação professor-aluno: uma leitura psicanalitica. Dissertacta Mestrado. São Paulo, Instituto de Psicologia/USP,1982.

Lacaz, F.A.C Qualidade de vida no trabalho-doença. Revista Ciência e Saúde Coletiva, 5 (1), 2000.

Lane, S.T.M Linguagem, pensamento e representações sociais. In Lane, S.T.M e Codo, W.(Orgs) Psicologia social - o homem em movimento. Ed. Brasiliense, $2^{\mathfrak{a}}$ reimpressão, São Paulo, 1999.

Lapo, F.R Dos bancos escolares à cadeira da professora. In: Bueno, B. O.; Catani, D.B e Sousa, C.P. (Orgs) A vida e o oficio dos professores. São Paulo, Escrituras, 2000. pp 1169127.

Laurell, A . C A saúde- doença como processo social. Revista Latinoamericana de Salud, $n^{\circ}$ 2, México, 1982, pp. 7-25

Leavell, A.C e Clark, E.G Medicina Preventiva. São Paulo, McGraw-Hill, 1976

Lefèvre,F Saúde, mídia e reificação. In: Pitta, A. M. R Saúde e Comunicação: visibilidades e silêncios. São Paulo. Abrasco/Hucitec, 1995.

Lehmann, E.L. Nonparametrics Statistical Methods Based on Ranks. San Francisco:

Holden-Day Inc., 1975.

Lima, R.C.S. - Trabalhador 2000: inteligente, criativo, emocionado, participativo. In: Borges, L.H., Moulin, M.G.B. e Araújo, M.D. (orgs.) - Organização do trabalho e saúde. Vitória, CCHN Publicações e EDUFES, 2001. pp. 55-65.

Louro, G.L. - Mulheres na sala de aula. In: Del Priorre, M. (Org) - História das mulheres no Brasil. São Paulo, Contexto e Unesp, $2^{\mathrm{a}}$. ed., 1997. pp.443-480.

Loyola, M.A. - Médicos e Curandeiros: Conflito Social e Saúde. São Paulo, Editora Difel, 1984.

Lüdke, M. e André, M.E.D.A. - Pesquisa em educação: abordagens qualitativas. São Paulo, Ed. Pedagógica e Universitária. 1986.

Mattiske, J.A.; Oates, J.M. e Geenwood, K.M. - Vocal problems among teachers: a review of prevalence, causes, prevention and treatment. Philadelphia, Journal of voice n. 12, 1998. pp. $489-499$.

Märtz, M.L.W. - Os usos sociais da voz. Revista Dist. Comunicação, 2 (3/4), São Paulo, Educ, 1987, pp. 173-6.

Märtz, M.L.W. - Algumas reflexões sobre terapia da voz. Revista Dist. Comunicação, 10(2)? 205-11. São Paulo, Educ, 1999. p. 205-11. 


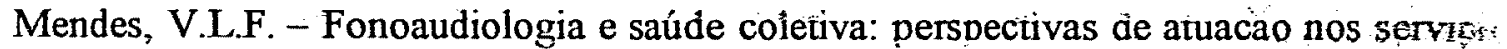
públicos de saúde. In: Revista Dist. Comunicação, 10(2):205-11. São Paulo, Educ, 1999, pp.213-24.

Mendes R. e Dias, E.C. - Saúde dos trabalhadores. In: Rouquariol. M. e Filho, N. Epidemiologia e saủde. São Paulo, Medsi, 1999.

Mendes, A.M. e Morrone, C.F. - Vivências de prazer-sofrimento e saúde psíquica no trabalho: trajetória conceitual e empirica. In: Mendes, A.M., Borges, L.O. e Ferreira, M.C. - Trabalho em transição, saúde em risco. Brasília, UNB e FINATEC, 2002, pp. 25-42.

Menegon, V.M. - Porque jogar conversa fora? Pesquisando o cotidiano. In: Spink, MJ. (org) - Práticas discursivas e produção de sentidos no cotidiano: aproximações teóricas e metodológicas. São Paulo, Ed. Cortez, 1999. pp. 215-241.

Minayo, M.C.S. - Ciencia, técnica e arte: o desafio da pesquisa social. In: Minayo, M.C.S. (org) - Pesquisa social - teoria, método e criatividade. Rio de Janeiro, Ed. Vozes, $7^{\mathrm{a}}$. edl, 1997-a. pp.9-30.

Minayo, M.C.S. - A análise de dados em pesquisa qualitiativa. In: Minayo, M.C.S. (org) Pesquisa social - teoria, método e criatividade. Rio de Janeiro, Ed. Vozes, $7^{\text {a }}$. edl, 1997-a. pp.67-80.

Minayo, M.C.S. - Saúde e doença como expressão cultural. In: Amâncio Filho, A e Moreira, M.C.G.B. (Orgs) - Saúde, trabalho e formação profissional. Rio de Janeiro, Fiocruz, 1997-c. pp. 31-39.

Minayo, M.C.S.; Hartz, Z.M.A. e Buss, P.M. - Qualidade de vida e saúde: um debate necessário. Revista Ciência e Saúde Coletiva, no. 5 v.1, Abrasco, 2000.

Ministério Da Saúde - Promoção da Saúde. Brasília (D.F), 1996.

Ministério Da Saúde - Promoção da Saúde. Brasília (D.F), 2001.

Moraes, M.C. L. e Rabinovich, E.P. - Resiliência: uma discussão introdutória. CDHRevista Brasileira Cresc. e Desenv. Hum. 6 (1/2). São Paulo, FSP/USP, 1996. pp-10-13.

Morgado, M.A. - Da sedução na relação pedagógica: professor-aluno no embate com afetos inconscientes. São Paulo, Plexus, 1995.

Morton. V. e Watson. D.R. - The teaching voice:problems and perceptions. Log. Phon. Vocol. N23. Scandinavian University Press. 1998. pp. 133-139.

Murray, D.; Morrison, M.D.; Linda, A.; Rammage, B.A.; Gilles, M; Belisle, M.D.; Bruce Pullan, M.A; Hamish Nichol, M.B. - Muscular tension dysphonia. The journal of Otolaryngology 12, 1983. pp. 302-6. 
Nagano, L. Perfil vocal e análise perceptivo auditiva das vozes ae proressoras a escola. Monografía de especialização, CECEV, São Paulo, 1994.

Nagano, L. e Behlau, M. Perfil vocal e análise perceptivo-auditiva das vozes de professores de pré-escola. In: Behlau, M. (Org) - A voz do especialista. Rio de Janeiro, Revinter, 2000. pp. 45-56.

Nakamura, M.R.S. O trabalho alienado e a miséria psíquica e corporal. Dissertação de Mestrado em Psicologia Social. Pontificia Universidade Católica de São Paulo- PUC/SP. São Paulo, 1997.

Navas, D.M. e Dias, P.R. Disfonias funcionais. In: Pinho, S.M.R. Fundamentos em fonoaudiologia. Rio de Janeiro, Guanabara Koogan, 1998. pp.73-79.

Neves, M.Y. e Athayde, M. Saúde, gênero e trabalho na escola: um campo de conhecimento em construção. In: Brito, J.; Athayde, M. e Neves, M.Y. (Orgs) Saúde e trabalho na escola. Rio de Janeiro, CESTEH/ENSP/FIOCRUZ, 1998. pp. 23-35.

Neves, M.Y. e Silva, E.S. Trabalho docente: precarização e feminização de uma prática profissional. In: Brito, J.; Barros, M.E.; Neves, M. e Athayde, M. (Orgs) - Trabalhar na escola? Só inventando o prazer. Rio de Janeiro, Ed. IPUB-CUCA, 2001. pp.23-50.

Novaes, M.E. Professora primária: mestra ou tia?. São Paulo, Cortez, 6 ed., 1995.

Nóvoa, A. (Org) Vida de professores. Portugal, Ed. Porto, $2^{\circ}$ ed, 1995.

Nutbeam, D. Glossario de promoción de la salud. In: OPAS / OMS Promoción de la salud: una antologia. Washington, EUA, 1996.

O. I. T. (Organización Internacional del Trabajo) Empleo y condiciones de trabajo del personal docente. Relatório Final da Reunión paritaria sobre las condiciones de trabajo del pemonal docente. Genebra, 1981.

O. I. T. (Organización Internacional del Trabajo) Segunda reunión paritaria sobre condiciones de trabajo del pernonal docente. Informe Final. Genebra, 1991.

Oliveira, C.G. - Fonoaudiologia e a questão da saúde do trabalhador. São Paulo, Revista. Dist. da Comunicação 7(2), 1995. pp. 135-146.

Oliveira, I.B. (e cols). - Distúrbios vocais em professores da pré-escola e primeiro grau. In: Ferreira, L.P.; Oliveira, I.B.; Quinteiro, E.A. e Morato, E.- Voz profissional-o profissional da voz. Carapicuíba, Ed. Pró-Fono, 1995. pp. 173-181.

Oliveira, IB. - Da voz do professor. In: SBFA - Fonoaudiologia Hoje. São Paulo, Frontis Editorial, 1998. pp.61-68. 
Oliveira, I.B. Sintomas vocais em professores: o que podem significar?. Anais do IV Congresso Internacional de Fonoaudiologia e III Encontro Ibero-Americano de Fonoaudiologia. SBFa. São Paulo, 1999. pp. 543.

Oliveira, I.B. Prevalência de alterações vocais e laríngeas em professores. Congresso Brasileiro de Fonoaudiologia, Guarapari (ES), 26 a 30 de setembro de 2001.

Oliveira Jr., A.W. Glossolalia: voz e poesia. Dissertação de Mestrado. São Paulo, Pontificia Universidade Católica - PUC/SP, 2001.

Oliveira, S.T. O caminho da fonoaudiologia: avanços e perspectivas. O mundo da saúde, ano 23 v.23 n.6., São Paulo, 1999.

Oliveira, F.O. e Werba, G.C. Representações sociais. In: Jacques, M.G.C et al.- Psicologia social contemporânea. Petrópolis, Ed. Vozes, $4^{\text {a }}$ ed, 2000. pp. 104-117.

OPAS/OMS Escuelas promotoras de la salud-entornos saudables y mejor salud para als generaciones futuras. Comunicación para a salud $n^{\circ}$ 13. Washington, DC, 1996.

Orlandi,E.P. A linguagem e seu funcionamento-as formas do discurso.Campinas, Pontes, 1996.

Patton, M.Q. Qualitative evaluation methods. Bervely Hills, Sage, 1987.

Pelicioni, M.C.F Educação em Saúde e Educação Ambiental: estratégias de construção da Escola Promotora da Saúde. Tese de·Livre Docência. São Paulo, Faculdade de Saúde Pública/USP, 2000.

Pelicioni, M.C.F. Conceito e formação de grupo. São Paulo, Faculdade de Saúde Pública/USP (mimeo, s/d)

Penteado, R.Z. Fonoaudiologia e Escolas Promotoras de Saúde: algumas reflexões. In: LACERDA, C. e PANHOCA, I.- Tempo de Fonoaudiologia III. Taubaté, Cabral, 2002. pp.175-200.

Penteado, R.Z. Folders das campanhas nacionais da voz - análise dos aspectos de apresentação, conteúdo e linguagem. In: Revista Distúrbios da Comunicação. v 14 (2). São Paulo, 2003. pp. 319-349.

Penteado, R.Z. e Bicudo-Pereira, I.M.T. - A voz do professor: relações entre trabalho, saúde e qualidade de vida. São Paulo, Revista Brasileira de Saúde Ocupacional vol. 25. Fundacentro, 1999. pp.109-130.

Penteado, R.Z. e Seabra, M.N. O contexto familiar numa abordagem integrativa da fonoaudiologia e terapia ocupacional em saúde da criança. In: Marchesan, I.Q. et al - Tópicos em fonoaudiologia - Vol. IV. São Paulo, Ed. Lovise, 1998. 
Pereira, C.A.A. e Engelmann, A. Um estudo da qualidade de vida universitária no trabalho entre docentes da UFRJ. In: Arquivo Brasileiro de Psicologia 45 (3/4) 1993. pp. 12-48.

Pereira, J.C.R. Análise de Dados Qualitativos: Estratégias Metodológicas para as Ciências da Saúde, Humanas e Sociais. São Paulo: EDUSP-FAPESP, 1999.

Pereira, M; Santos, $M$ e Viola, I. Influência do nível de ruído em sala de aula sobre a performance vocal do professor. In: Ferreira, L.P. e Costa, H. Voz ativa-falando sobre o profissional da voz. Rocca, São Paulo, 2000. pp. 57-65.

Peres, S.A.B. - Catapulta!. In: BUENo, B.O.; Catani, D.B. e Sousa, C.P. (Orgs) $A$ vida e o oficio dos professores. São Paulo, Escrituras, 2000.pp.83-100.

Pessanha, E.C. Ascensão e queda do professor. São Paulo, Cortez, 1994.

Pichon-Rivière, E. O processo grupal. São Paulo, Ed. Martins Fontes, 1982.

Pichon-Rivière, E. Teoria do vinculo. 6 ed, São Paulo, Ed. Martins Fontes, 1998.

Pinho, S.M.R. Manual de higiene vocal para profissionais da voz. Carapicuíba, Pró-Fono, 1997.

Pinto, A.M.M. e Furck, M.A.E. Projeto saúde vocal do professor. In: Ferreira, L.P. (Org). Trabalhando a Voz. São Paulo, Summus Editorial, 1988. pp.11-27.

Pordeus, A.M.J.; Palmeira, C.T. e Pinto, V.C.V. Inquérito de prevalência de problemas da voz em professores da universidade de Fortaleza. Carapicuíba, Pró-Fono Revista Atual. Científica. vol. 8(2), 1996. pp.15-30.

Possenti, S. Discurso, estilo e subjetividade. São Paulo, Ed. Martins Fontes, 1988.

Rago, M. - Trabalho feminino e sexualidade. In: Del Priore, M. (Org) - História das mulheres no Brasil. São Paulo, Contexto e Unesp, $2^{*}$ ed, 1997. pp. 578-606.

Ramírez, M.L.C. Calidad de vida y promoción de la salud. In: Restrepo, H.E. e Málaga, H. Promoción de la salud: cómo construir vida saludable. Bogotá, Editorial Médica Panamericana, 2001. pp.56-64.

Reinhold, H.H. Stress ocupacional do professor. In: Lipp, M. (Org) Pesquisas sobre stress no Brasil-saíde, ocupação e grupos de risco. Campinas, Papirus, 1996. pp. 169-193

Restrepo, H.E. Agenda para la acción en promoción de la salud. In: Restrepo, H.E. e Málaga, H. Promoción de la salud: cómo construir vida saludable. Bogotá, Editorial Médica Panamericana. 2001. pp. 34-55.

Rey, G. Pesquisa qualitativa em psicologia - caminhos e desafios. São Paulo, Thomson/Pioneira, 2002. 
Ribeiro, H.P.- $A$ voz como instrumento de trabalho e as repercussões sobre a saúde dos seus trabalhadores (mimeo). Trabalho apresentado no XI Seminário de Voz - Disfonia como Doença do Trabalho. São Paulo, PUC/SP, nov/2001.

Ribeiro, P.A.; Penteado, R.Z.; Medrado, R.B.S. e Giannini, S.P.P.- Voz e Ciências Sociais. (Mimeo). Trabalho apresentado à disciplina Voz, Psiquismo e Sociedade, sob coordenação da Profa. Léslie Piccolotto Ferreira. São Paulo, PUCSP, 2002.

Rigotto, R.M. - Investigando a relação entre saúde e trabalho. In: Buschinelli, J.T.P.; Rocha, L.E. (Orgs) - Isto é trabalho de gente? - vida, doença e trabalho no Brasil. Vozes, Petrópolis, 1993.

Rocha, L.E. e Glima, D.M.R. - Distúrbios psíquicos relacionados ao trabalho. In: Ferreira Júnior, M. (Org)-Saúde no trabalho. São Paulo, Ed. Roca, 2002. pp.320-351.

Rocha, M.L. e Gomes, L.G.W. - Saúde e trabalho: a educação em questão. In: Brito, J.; Barros, M.E.; Neves, M. e Athayde, M. (Orgs) - Trabalhar na escola? Só inventando o prazer. Rio de Janeiro, Ed. IPUB-CUCA, 2001. pp. 251-277.

Rocha, M.L.; Gustavo, L. e Gomes, W. - Saúde e trabalho: a educação em questão. In: Brito, J.; Barros, M.E.; Neves, M. e Athayde, M. (orgs) - Trabalhar na escola? Só inventando o prazer. Rio de Janeiro, Ed. IPUB-CUCA, 2001. pp. 251-277.

Rocha, L.E. e Junior, M.F. - Distúrbios osteomusculares relacionados ao trabalho. In: Ferreira Júnior, M. (Org)-Saúde no trabalho. São Paulo, Ed. Roca, 2002. pp. 286-318

Rodrigues, J.C. Tabu do Corpo. Rio de Janeiro, Dois Pontos Editora, 1986.

Rodrigues, $\mathrm{S}$; Azevedo, R. e Behlau, M - Considerações sobre voz profissional falada. In: Marchesan, I; Zorzi, J.; Gomes, I-Tópicos em fonoaudiologia volil. São Paulo, Lovise, 1996. pp. 701-711.

Rosa, M.I. - Trabalho, subjetividade e poder-trabalhador profissional, antigo de casa: um estudo de caso. São Paulo, Tese de doutorado FFLCH/USP, 1991.

Rosa, MI. - Trabalho, subjetividade e poder. São Paulo, Edusp e Letras e Letras, 1994.

Rotemberg, L.; Portela, L.F.; Marcondes, W.B; Moreno, C. e Nascimento, C.P. - Gênero e trabalho noturno: sono, cotidiano e vivências de quem troca a noite pelo dia. Caderno de Saúde Pública, 17(3), pp. 639-649, Rio de Janeiro, 2001.

Rozemberg, B. e Minayo, M.C.S. - A experiência complexa e os olhares reducionistas. O sujeito e a subjetividade na práxis da saúde, Revista Ciência e Saúde Coletiva, ABRASCO, v. $6 n^{\circ} 1,2001$. 
Sadalla, AM.F.A. Com a palavra, a professora: suas crenças, suas ações. Campinas, Ed. Alínea, 1998.

SAS Institute. SAS/STAT User's Guide 8.0. Cary, N.C.: SAS Institute Inc., 1999.

Scalco, M.A.; Pimentel, R.M. e Pilz, W. A saúde vocal do professor: levantamento junto a escolas particulares de Porto Alegre. Pró-Fono, Rev. atual cient. 8 (2), pp. 25-30, 1996.

Seifert, A.M. - Trabalho y salud en las y los educadores de escuelas. Salud de los trabajadores. (Editorial). Vol.7 n. ${ }^{\circ}$ 2. Universidade. de Carabobo, Venezuela, 1999.

Servilha, E. A.M Caracterização do perfil vocal em professores do terceiro grau. In: Lacerda, C.B.F. e Panhoca, I.- Tempo de Fonoáudiologia II. Ed. Cabral Univ., Taubaté, 1998.

Servilha, E.A.M. A voz do professor: indicador para compreensão da dialogia no processo ensino-aprendizagem. Tese de doutorado, PUC-Campinas. Campinas, 2000.

Servilha, E.A.M. Flexibilidade vocal: recurso da voz docente para chamar a atenção dos alunos. Anais: IX Congresso Brasileiro de Fonoaudiologia, Guarapari (ES), 26 a 30 de setembro de 2001. Trabalho 226.

Servilha, E.A.M.; Santos, F.; Bergantin, M.; Domingues, T.S. Druzian Mapeamento vocal: estratégia para conhecer e proteger a voz do professor. Anais: IX Congresso Brasileiro de Fonoaudiologia, Guarapari (ES), 26 a 30 de setembro de 2001. Trabalho 227.

Silva, M.A.A - Saúde vocal. In: Pinho, S.M.R. Fundamentos em fonoaudiologia: tratando os distúrbios da voz. Rio de Janeiro, Ed. Guanabara Koogan, 1998. pp. 119-125.

Silva, C. S. - A escola promotora de saúde na agenda politica do municipio do Rio de Janeiro. Saúde em Foco. Secretaria Municipal de Saúde do Rio de Janeiro. Rio de Janeiro, 2002. pp. 83-102.

Silva Filho, J.F.- Ensino e trabalho: reproduzir ou transformar. In: Brito, J.; Barros, M.E.; Neves, M. e Athayde, M. (Orgs) Trabalhar na escola? Só inventando o prazer. Rio de Janeiro, Ed. IPUB-CUCA, 2001. pp. 17-20.

Silvany Neto, A.M; Araújo, T.M; Kawalkievicz, C.; Lima, B.G.; Dutra, F.R.; Paiva, L.C.; Samo, M.M. Condições de trabalho e saúde em professores da rede particular de ensino na Bahia: estudo piloto. Revista Brasileira de Saúde Ocupacional n ${ }^{\circ} 91 / 92$ vol. 24. São Paulo, Fundacentro, 1998.

Silveira, G.T. Escola promotora de saúde: quem sabe faz a hora!. Tese de Doutorado. Faculdade de Saúde Pública/USP. São Paulo, 2000. 
Simão, A.L.F. e Chun, R.Y.S. Do movimento a voz surge naturalmente. In: Lacerda, C.B.F. e Panhoca, I. Tempo de Fonoaudiologia I Ed. Cabral Universidade. Taubaté, 1997.

Simões, M-Prevalência de disfonia e estudo de seus fatores associados em educadoras de creche. Dissertação de Mestrado. São Paulo, Faculdade de Saúde Pública/USP, 2001.

Sleegers, P. - Professional identity, school reform, and burnout: some reflections on teacher burnout. In: Vandenberghe, $\mathrm{R}$ e Huberman, A. Understanding and preventing teacher burnout: a sourcebook of international research and practice. Cambridge University,. Press, XV, New York, 1999.

Smith, E. et al Effect of voice disorders on quality of life. London, Jaurnal of Medical Speech-Language Pathology. v. 4 n $^{\circ}$ 4. Singular Publishing Group, 1996.'

Smith, E; Gray, S.; Dove, H; Kirchner, L. e Heras, H. Frequency and effects of teacher's voice problems. Philadelphia, Journal of Voice, 1997. pp. 81-87.

Smith, E.; Lemke, J.; Taylor, M.; Kirchner, H.L. e Hoffman, H. Frequency of voice problems among teachers and other occupations. Philadelphia, Journal of Voice, 1998. 12(4)pp. 480488.

Soares Júnior, J.M.; Pianetti, G. M.; Cecílio, S. e Teixeira, V.P.A. A saúde do professor do sexo feminino do ensino primário. Revista Brasileira de Medicina v. 51 n.7, 1994. pp. $891-8$.

Soratto, L. e Olivier-Heckler, C Os trabalhadores e seu trabalho. In CODO, W. (Coord.) Educação: carinho e trabalho. Petrópolis/Vozes e Brasília/Conf. Nac. dos Trab. em Educação, $2^{\text {a }}$ ed., 2000 -a. pp. 89-110.

Soratto, L. e Olivier-Heckler, C Trabalho: atividade humana por excelência. In: Codo, W. (Coord.) Educação: carinho e trabalho. Petrópolis/Vozes e Brasilia/Conf. Nac. dos Trab. em Educação, $2^{\text {a }}$ ed., 2000-b. p. 111-136.

Soratto, L. e Pinto - Burnout e carga mental no trabalho. In: Codo, W. (Coord.)- Educação: carinho e trabalho. Petrópolis/Vozes e Brasília/Conf. Nac. dos Trab. em Educação, $2^{2}$ ed., 2000. p. 282-291.

Soratto, L. e Ramos, F. - Bumout e relações sociais no trabalho. In: Codo, W. (Coord.) Educação: carinho e trabalho. Petrópolis/Vozes e Brasilia/Conf. Nac. dos Trab. em Educação, $2^{\text {a }}$ ed., 2000. p.272-277.

Spiegel, M.R Estatística. 3. ${ }^{a}$ ed. São Paulo: Makron Books, 1993

Spink, M.J. (Org) Práticas discursivas e produção de sentidos no cotidiano - aproximações teóricas e metodológicas. Ed. Cortez, São Paulo, 1999. 
Spink, M.J. Desvendando as teorias implícitas: uma metodologia de análise das representações sociais. In: Guareschi, P. e Jovchelovitch, S. (Orgs) -Textos em representações sociai, $6^{\text {a }}$ ed. Vozes, Petrópolis, 2000.

Spink, M.J. e Medrado, B. - Produção de sentidos no cotidiano: uma abordagem teóricometodológica para análise das práticas discursivas. In: Spink, M.J. (org) - Práticas discursivas e produção de sentidos no cotidiano: aproximações teóricas e metodológicas. Ed. Cortez, São Paulo, 1999. pp. 41-61.

Stacciarini, J.M. e Tróccoli, B.T. Estresse ocupacional. In: Mendes, A.M., Borges, L.O. e Ferreira, M.C. Trabalho em transição, saúde em risco. Brasília, UNB e FINATEC, 2002. pp. 185-205.

Stier, M.A.; Macedo, E.; Brandalise, J.; Graçano, S.; Macedo, C.; Gomes, G.F. Programa de saúde e qualidade vocal dos 6000 professores da rede municipal de ensino de Curitiba. In: BEHLAU, M. (Org) Laringologia e Voz hoje. Rio de Janeiro, Revinter, 1998. p. 411

Stone Jr, R.E. Revisiting the mechanisms of vocal abuse. In: Behlau, M. (Org) Laringologia e Voz hoje. Rio de Janeiro, Ed. Revinter, 1998. p.28.

Tetaga, J.E. Challengers to implementing health promoting schools: the Papua New Guinea experience. Promotion e Education, vol. IV, march, 1997.

Thiollent, M. A critica metodológica: investigação social e enquete operária. Ed. Polis, São Paulo, 1982.

Thomé De Souza, T.M. O professor e sua voz - um difícil encontro. In: Behlau, M. (Org) Laringologia e Voz hoje. Rio de Janeiro, Ed. Revinter, 1998. p. 452.

Thomé De Souza, T.M. e Fereira, L.P. Um século de cuidados com a voz profissional falada: a contribuição da Fonoaudiologia. Revista Sociedade Brasileira de Fonoaudiologia, ano 2, supl. 1, 1988. pp.26-35.

Thomé De Souza, T.M. e Fereira, L.P. Um século de cuidados com a voz profissional falada: a contribuição da Fonoaudiologia. In: Ferreira, L.P. e Costa, H. Voz ativa-falando sobre o profissional da voz. Rocca, São Paulo, 2000. pp.1-20.

Thomé De Souza, T.M. e Fereira, L.P. Caracterização vocal dos professores do município de São Paulo- DREM-5. In: Ferreira, L.P. e Costa, H. Voz ativa-falando sobre o profissional da voz. Rocca, São Paulo, 2000-b. pp.145-162.

Triviños, A.N.S. Introdução à pesquisa em ciências sociais - a pesquisa qualitativa em educação. Ed. Atlas, São Paulo, 1995.

Vasconcelos, E.M. Educação popular e a atenção à saúde da família. Ed. Hucitec e M.S. São Paulo, 1999. 
Vasques-Menezes, I., Codo, W. e Medeiros, L. O conflito entre o trabalho e a família e o sofrimento psíquico. In: CODO, W. (Coord.) Educação: carinho e trabalho. Petrópolis/Vozes e Brasília/Conf. Nac. dos Trab. em Educação, $2^{a}$ ed., 2000. pp. 255-260.

Vasques-Menezes, I. e Gazzotti, A.A. A si mesmo como trabalhador . In: Codo, W. (Coord.) Educação: carinho e trabalho. Petrópolis/Vozes e Brasília/Conf. Nac. dos Trab. em Educação, $2^{2}$ ed., 2000. pp. 368-383.

Vasques-Menezes, I. e Soratto, L. Burnout e suporte social. In: Codo, W. (Coord.)Educação: carinho e trabalho. Petrópolis/Vozes e Brasília/Conf. Nac. dos Trab. em

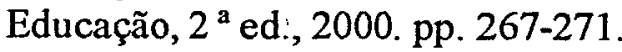

Vaz, A.C.N. et al. Ocorrência de queixas vocais em professores da rede municipal de educação da cidade de São Paulo. Anais do IV Congresso Internacional de Fonoaudiologia e III Encontro Ibero-Americano de Fonoaudiologia. SBFa. São Paulo, 1999. p. 396

Vaz, A.C.N. et al. Voz do professor: prevenir é preciso. In: FERREIRA, L.P. e SILVA, M.A.A. Saúde vocal-práticas fonoaudiológicas. São Paulo, Ed. Roca, 2002. pp. 199-205.

Veja Especial Sono: a boa noite dos jovens. Revista VEJA Edição Especial Saíde $n^{\circ} 20$ ano 35. São Paulo, Ed. Abril, novembro de 2002. pp. 50-51.

Vieira, M.M.-Voz e relação educativa. Ed. Afrontamento, Porto, Portugal, 1996.

Vilkman, E. Voice problems at work: a challenge for occupational safety and health arrangement. Folia Phoniatr. Logop. n.52, 2000. pp. 120-125.

Vox Bralilis Primeira reunião pró-consenso nacional sobre voz profissional - Voz e trabalho: uma questão de saúde e direito do trabalhador. Boletim da Sociedade Brasileira de Laringologia e $\mathrm{Voz}$, ano 7 n², 2001. pp.9-12.

Vygotzky, L.S. A formação social da mente. Ed. Martins Fontes, São Paulo, 1995.

Waller, R.A. Statistics: An Introduction to Numerical Reasoning. San Francisco: HoldenDay, Inc., 1979.

Ware, J.E. e Sherbourne,C.D. - The MOS 36-item short-form health survey (SF-36). Conceptual framework and item selection. Boston, Med Care, 30(6), 1992. pp. 473-83.

Wertsch, J.V.; Del Río, P. e Alvarez, A. Estudos socioculturais da mente. Ed. Artes Médicas, Porto Alegre (R.S.), 1998.

Westphal, M.F. Recursos educativos e métodos de avaliação em promoção de saúde. FSP/USP, São Paulo, mimeo, 1998.

Westphal, M.F. O movimento de cidades/municípios saudáveis: um compromisso com a qualidade de vida. Revista Ciência e Saúde Coletiva, $n^{\circ} 5$ v. 1. Abrasco, 2000. 
Westphal, M.F.; Bógus, C.M. e Faria, M.M. Grupos tocais: experièncias precursoras at programas educativos em saúde no Brasil. Boletim Oficina Sanitária Panamericana 120 (6), 1996.

Witter, G.P. - Implicações sociais da linguagem. In: CRFa. $2^{*}$ Região Encontro Nacional de Fonoaudiologia Social e Preventiva. (Anais). São Paulo, 1988.

Wojciehwski, A.P.F. e Heemann, C.S. Saúde vocal do professor: a prevenção como fator primário. In: Behlau, M. (Org) Laringologia e Voz hoje. Rio de Janeiro, Ed. Revinter, 1998. p.315.

Zimerman, D.E.- Classificação geral dos grupos. In: Zimerman, D; Osório, L. e Cols Como trabalhamos com grupos. Ed. Artes Médicas, Porto Alegre (R.S.), 1997. 


\section{CENTRO DE ESTUDOS DA VOZ - CEV \\ Mensuração de Qualidade de Vida Relacionada à Voz \\ Traduzido e adaptado por Dra. Mara Behlau}

Estamos procurando compreender melhor como um problema de voz pode interferir nas atividades de vida diária. Apresentamos uma lista de possíveis problemas relacionados à voz. Por favor, responda a todas as questões baseadas em como sua voz tem estado nas duas últimas semanas. Não existem respostas certas ou erradas.

Circule como você avalia sua voz:

\section{Excelente 2. Muito boa 3.Boa 4. Razoável 5. Ruim}

Para responder ao questionário; considere tanto a severidade do problema, como sua freqüência de aparecimento, avaliando cada item abaixo de acordo com a escala apresentada. A escala que você irá utilizar é a seguinte:

1 = nunca acontece e não é um problema

$2=$ acontece pouco e raramente é um problema

$3=$ acontece às vezes e é um problema moderado

4 = acontece muito e quase sempre é um problema

5 = acontece sempre e realmente é um problema ruim

\section{Por causa de minha voz,}

1. Tenho dificuldades em falar forte (alto) ou ser ouvido em ambientes ruidosos.

2. O ar acaba rápido e preciso respirar muitas vezes enquanto eu falo.

3. Não sei como a voz vai sair quando começo a falar.

4. Fico ansioso ou frustrado (por causa da minha voz).

5. Fico deprimido (por causa da minha voz).

6. Tenho dificuldades ao telefone (por causa da minha voz).

7. Tenho problemas no meu trabalho ou para desenvolver minha profissão (por causa da voz).

8. Evito sair socialmente (por causa da voz).

9. Tenho que repetir o que falo para ser compreendido.

10. Tenho me tornado menos expansivo (por causa da niinha voz).

\section{O quanto isto é um problema?}

$\begin{array}{lllll}1 & 2 & 3 & 4 & 5\end{array}$

$\begin{array}{lllll}1 & 2 & 3 & 4 & 5\end{array}$

$\begin{array}{lllll}1 & 2 & 3 & 4 & 5\end{array}$

$\begin{array}{lllll}1 & 2 & 3 & 4 & 5\end{array}$

$\begin{array}{lllll}1 & 2 & 3 & 4 & 5\end{array}$

$\begin{array}{lllll}1 & 2 & 3 & 4 & 5\end{array}$

$\begin{array}{lllll}1 & 2 & 3 & 4 & 5\end{array}$

$\begin{array}{lllll}1 & 2 & 3 & 4 & 5\end{array}$

$\begin{array}{lllll}1 & 2 & 3 & 4 & 5\end{array}$

$\begin{array}{lllll}1 & 2 & 3 & 4 & 5\end{array}$ 


\section{VERSÃO EM PORTUGUÊS DOS INSTRUMENTOS DE AVALIAÇÃO DE QUALIDADE DE VIDA (WHOQOL) 1998}

Por favor, leia cada questão, veja o que você acha e circule no número e the parece a melhor resposta.

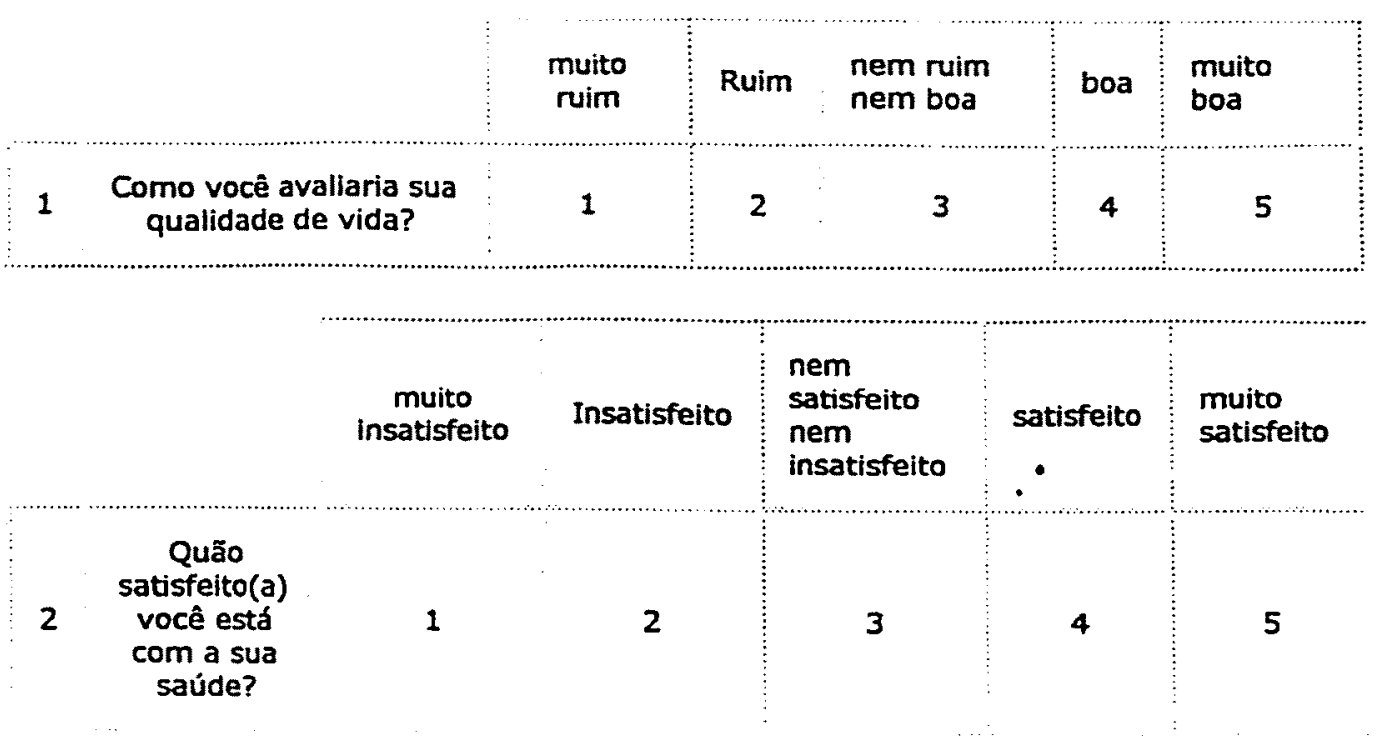

As questões seguintes são sobre o quanto você

tem sentido algumas coisas nas últimas duas semanas.

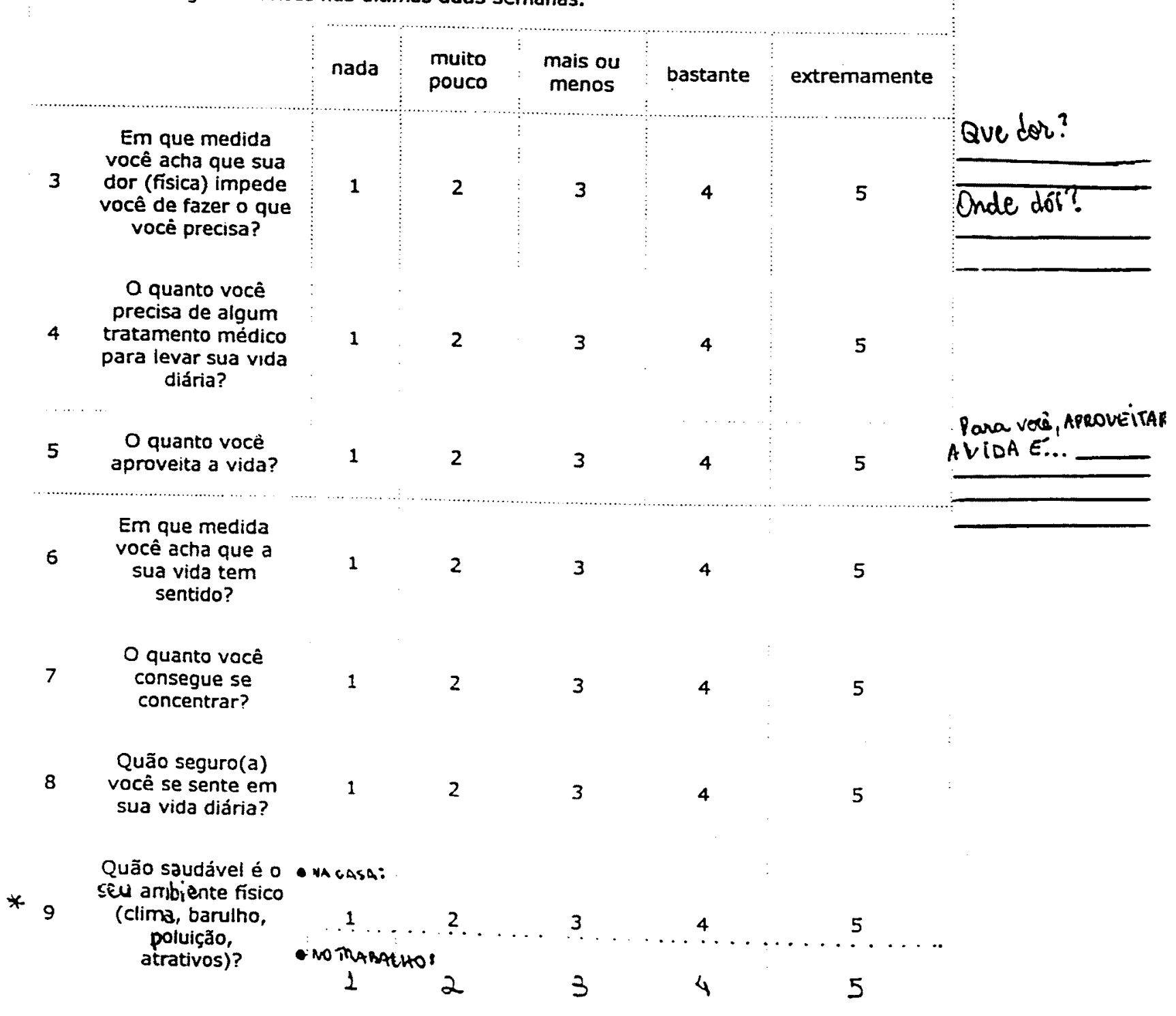




As questões seguintes perguntam sobre quão completamente você tem sentido ou é
capaz de fazer certas coisas nestas últimas duas semanas.

As questð̃es seguintes perguntam sobre quão bem ou satisfeito você se sentiu a respeito de vários aspectos de sua vida nas últimas duas semanas.

15

Quão bem

de se

locomover?

muito insatisfeito

Insatisfeito

2

ruim

nem ruim nem bom

bom

muito

bom

3

4

5

4

nem

satisfeito satisfeito : Muito

nem

satisfeito

insatisfeito

Quão

satisfeito(a)

16

você está

com o seu

sono?

Quão

satisfeito(a)

você está

com sua

17 capacidade de

desempenhar

as atividades

do seu

dia-a-dia?

1

2

4

5 


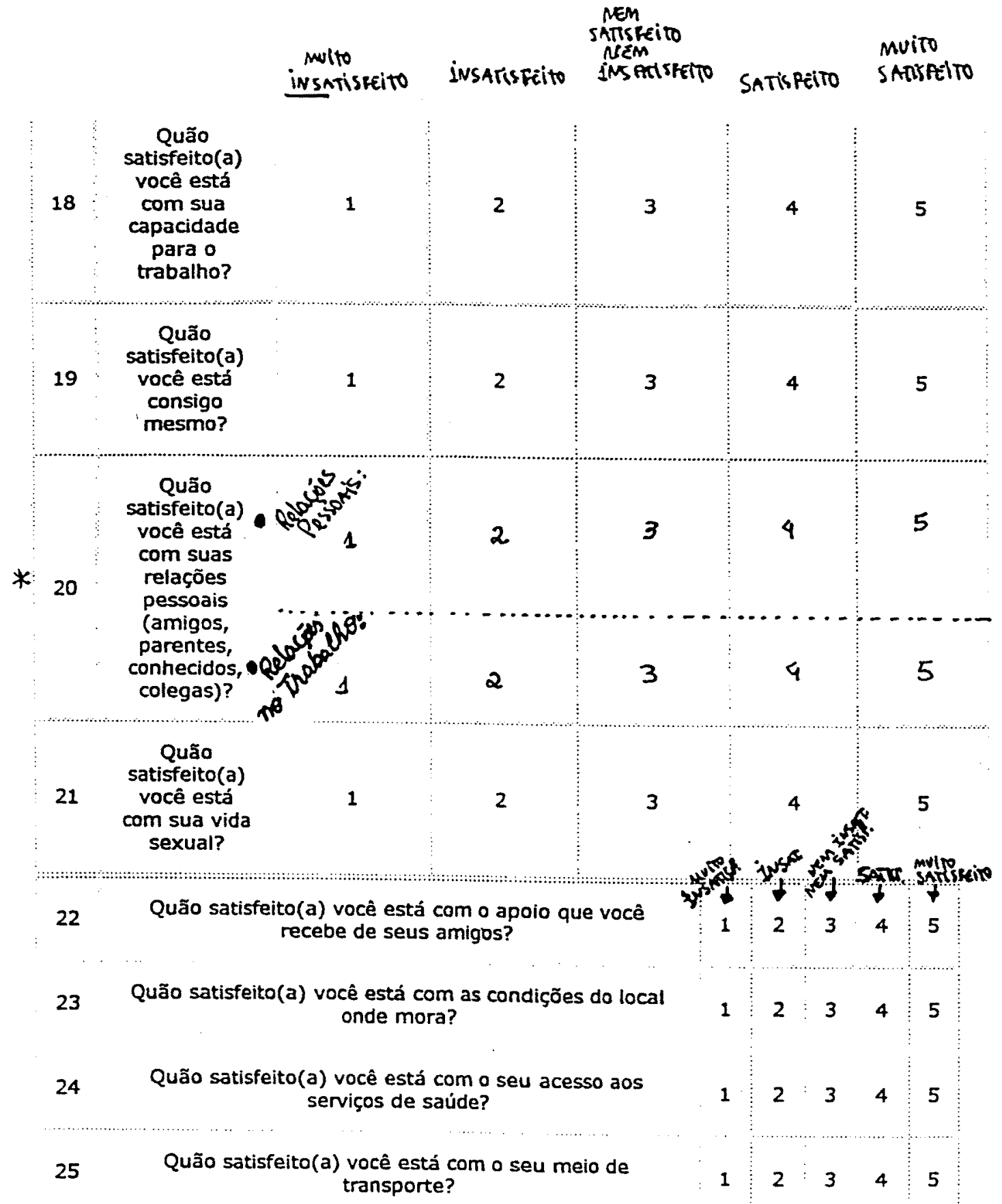

As questōes seguintes referem-se a com que freqüência você sentiu ou experimentou certas coisas nas últimas duas semanas.

nunca $\begin{gathered}\text { Algumas } \\ \text { vezes }\end{gathered}$ freqüentemente freqüentemente $\quad$ sempre

Com que
freqüência
vocé tem
sentimentos
negativos
tais como
mau humor,
desespero,
ansiedade,
depressão?




\section{Jtans VIIII \& IX do SF $36 \rightarrow$ ANEXO \\ 3}

VIII) Estas quetōes são sobre como roce se seate e como as coises tern estado aes ülimas 4 semanes. Parz cada questio, por favor, escolha a resposta que mais se aproxime da maneira que roce rem se sentido.

\begin{tabular}{|c|c|c|c|c|c|c|}
\hline $\begin{array}{l}\text { Quantas ve- } \\
\text { Zes durznte } \\
\text { As üloimas } \\
\text { i seman2s }\end{array}$ & $\begin{array}{l}\text { Todo } \\
\text { Tempo }\end{array}$ & $\begin{array}{l}\text { A mrior } \\
\text { parte do } \\
\text { rempo }\end{array}$ & $\begin{array}{c}\text { Uma boa } \\
\text { parte } \\
\text { do } \\
\text { rempo }\end{array}$ & $\begin{array}{l}\text { Algum } \\
\text { tempo }\end{array}$ & $\begin{array}{l}\text { Um pouco } \\
\text { do } \\
\text { tempo }\end{array}$ & $\begin{array}{c}\text { Nerhuma } \\
\text { parte } \\
\text { do } \\
\text { tempo }\end{array}$ \\
\hline $\begin{array}{l}\text { 1) Vocé se } \\
\text { seadiu com- } \\
\text { pleto como } \\
\text { pesso2 }\end{array}$ & & & & & & \\
\hline $\begin{array}{l}\text { 2) Voxé se } \\
\text { sentuu uma } \\
\text { pessoa muito } \\
\text { lo neriosa }\end{array}$ & & & & & & \\
\hline $\begin{array}{l}\text { 3) Vocé se } \\
\text { sentiu tāo } \\
\text { para bairo } \\
\text { que nin - } \\
\text { guem cnm- } \\
\text { scguiria a - } \\
\text { nima-lo }\end{array}$ & & & & & & \\
\hline $\begin{array}{l}\text { 4) Vocé se } \\
\text { sentiu cal - } \\
\text { mo e em } \\
\text { par }\end{array}$ & & & & & & \\
\hline $\begin{array}{l}\text { 5) Vocé se } \\
\text { sente cheio } \\
\text { de enerngiz }\end{array}$ & & & & & & \\
\hline $\begin{array}{l}\text { 6) Vixci se } \\
\text { sentiu desa- } \\
\text { nimado ou } \\
\text { deprimido }\end{array}$ & & & & & & \\
\hline $\begin{array}{l}7 \text { Voce se } \\
\text { sentiu esgo- } \\
\text { udo }\end{array}$ & & & & & & \\
\hline $\begin{array}{l}\text { 8) Vocé se } \\
\text { sentiu feliz }\end{array}$ & & & & & & \\
\hline $\begin{array}{l}\text { 9) Voce se } \\
\text { sentiu can - } \\
\text { sado }\end{array}$ & & & & & & \\
\hline
\end{tabular}

IX) Durante as ülumas 4 semanas quanto a sua saude Gsica e seus problemas emocionais interfiriram nas suas a ciridades socixis (como por exemplo: risitar amigos, pais, ete)?

\begin{tabular}{|l|l|l|l|l|}
\hline Todo tempo & $\begin{array}{l}\text { A maior par - } \\
\text { re do tempo }\end{array}$ & $\begin{array}{l}\text { Paste do } \\
\text { tempo }\end{array}$ & $\begin{array}{c}\text { lim pouco } \\
\text { de } \\
\text { rempo }\end{array}$ & $\begin{array}{c}\text { Nada } \\
\text { de } \\
\text { tempn }\end{array}$ \\
\hline
\end{tabular}

$$
\text { final do vuestionario }
$$




\section{ANEXO4}

Diagramas đe "ramos e folhas" para domínios da Qualidade de Vida relacionada à Voz (QVV)

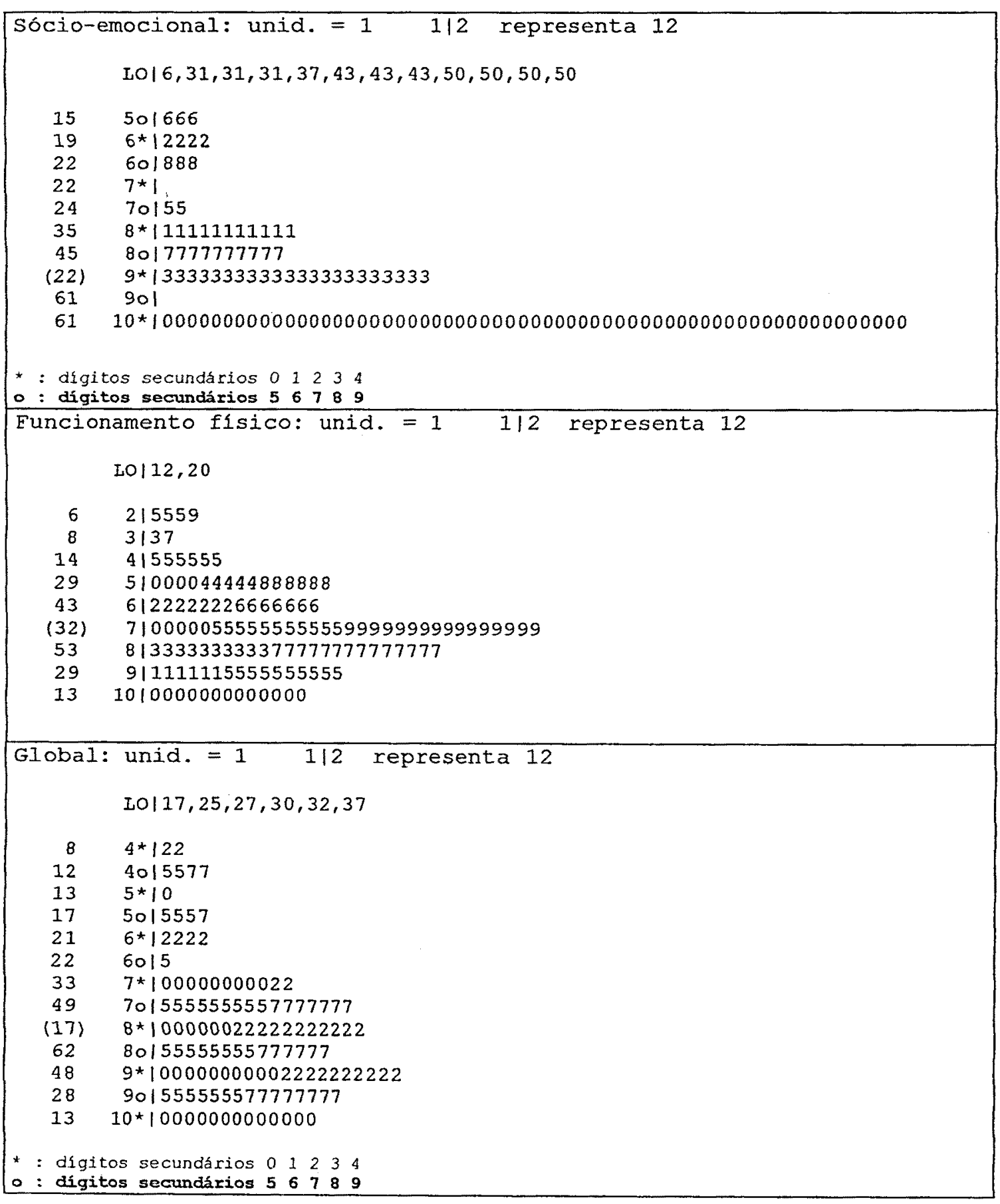




\section{ANEXO 5}

Diagramas de "ramos e folhas" para domínios da Qualidade de Vida (QV)

\begin{tabular}{|c|c|c|}
\hline \multirow{2}{*}{\multicolumn{2}{|c|}{$\begin{array}{l}\text { Físico: } \\
\text { unid. }=1 \quad 1 / 2 \text { representa } 12 \\
\text { Lo17,17,21,32,32 }\end{array}$}} & $\begin{array}{lll}\text { Psicológico: } & & \\
\text { unid. }=1 & 1 / 2 & \text { representa } 12\end{array}$ \\
\hline & & $10129,33,37,41$ \\
\hline \multicolumn{2}{|r|}{$\begin{array}{l}30159 \\
4 * 122\end{array}$} & 40155 \\
\hline 9 & $4 * 122$ & $5 * 10000000444444$ \\
\hline \multicolumn{2}{|r|}{40166} & 5018888888888 \\
\hline 21 & $4 0 \longdiv { 6 6 }$ & $6 * 1222222222222222222$ \\
\hline \multicolumn{2}{|c|}{60166666666666666666666} & \\
\hline 48 & $6 * 10000000000004444444444444$ & $7 * 100000000000000000$ \\
\hline 59 & 601777777777777 & Tol55555555555555555599999999999 \\
\hline (22) & \multirow{2}{*}{$7 * 111111111111111111111111$} & \\
\hline 47 & & $\begin{array}{l}8 * 1333333333 \\
80177777\end{array}$ \\
\hline 28 & \multirow{2}{*}{$\begin{array}{l}8 * 12222222222 \\
80155555555999\end{array}$} & $9 * 111$ \\
\hline & & \\
\hline 7 & $9 * 122$ & \multirow[t]{2}{*}{ HI 195,100} \\
\hline 5 & $\begin{array}{l}9016666 \\
10 * 10\end{array}$ & \\
\hline 1 & $10 * 10$ & $\begin{array}{l}* \text { : digitos secundários } 0112344 \\
0: \text { digitos secundários } 5677899\end{array}$ \\
\hline \multicolumn{3}{|c|}{ 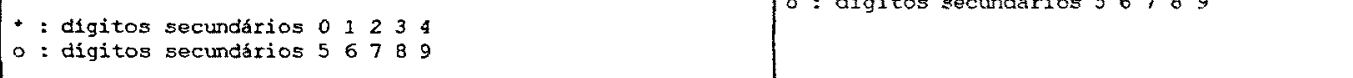 } \\
\hline \multicolumn{2}{|c|}{ Relações sociais: } & Meio ambiente: \\
\hline unid. & $=1 \quad 1 / 2$ representa 12 & unid. $=1 \quad 1 / 2$ representa 12 \\
\hline \multicolumn{2}{|r|}{ LO/25 } & $\begin{array}{l}2015588 \\
3 * 11444\end{array}$ \\
\hline 2 & 313 & 301777 \\
\hline 5 & $4 \mid 111$ & $4 * 100003333333$ \\
\hline 33 & 510000000008888888888888888888 & $40 \mid 666666666666$ \\
\hline 58 & 6) 666666666666666666666666666 & $5 * 10000000000033333333333333$ \\
\hline (42) & $7 \mid 5555555555555555555555555555555555555555555$ & $5 0 \longdiv { 6 6 6 6 6 6 6 6 6 6 6 9 9 9 9 9 9 9 9 9 9 9 9 9 9 9 9 }$ \\
\hline 28 & 8133333333333333333 & $6 * 1222222222222$ \\
\hline 11 & $9 / 111111111$ & 601555555555888 \\
\hline & 10100 & $7 * 111111111$ \\
\hline & & $7 0 \longdiv { 5 5 5 5 8 8 8 }$ \\
\hline & & $8 * 1144$ \\
\hline & & HII9O \\
\hline & & * : dígitos secundários 012234 \\
\hline & & 10: digitos secundários 56789 \\
\hline
\end{tabular}




\section{ANEXO 6 \\ TERMO DO CONSENTIMENTO LIVRE E ESCLARECIDO}

Este trabalho refere-se à pesquisa Aspectos de qualidade de vida e de subjetividade na promoção da saúde vocal do professor, desenvolvida pela fonoaudióloga Regina Zanella Penteado junto ao programa de Pós-graduação/Douturado da Faculdade e Saúde Pública/USP.

A pesquisa tem como objetivo investigar as relações entre qualidade de vida e voz/saúde vocal do professor. Busca compreender o fenômeno da saúde vocal do professor em suas relações com a qualidade de vida, sob uma perspectiva que incorpore a subjetividade, as percepções, os significados e os sentidos construídos social, cultural e historicamente, nos contextos cotidianos e condições de trabalho e vida do professor trabalhador.

Em setembro/2001 foi aprovada a primeira Lei Estadual para a implantação de Projetos de Saúde Vocal para o Professor. É preciso conhecer as condições de saúde, vida e trabalho do professor para estruturar propostas e projetos adequados à sua realidade e necessidades. Esta pesquisa visa subsidiar reflexões e contribuir para incrementar, qualitativamente, as propostas fonoaudiológicas na promoção da saúde vocal deste sujeito / trabalhador. Professor, a sua participação nesta pesquisa é muito importante, pois trata-se de um momento histórico na formação de projetos e serviços de atenção à sua saúde vocal e geral.

A sua colaboração será muito importante e, para isso, gostaria de contar com alguns minutos para responder sinceramente a dois questionários de múltipla escolha, com questões sobre aspectos da sua vida nas últimas duas semanas. Não deixe de responder nenhuma questão. Algumas pessoas poderão ser convidadas a participar de uma segunda etapa da pesquisa.

Os dados fornecidos serão sigilosos e é assegurado o anonimato das informações (não serão identificados os nomes das pessoas participantes nem das escolas). Esta pesquisa não oferece riscos nem desconfortos aos participantes e os seus dados serão utilizados para fins científicos, incluindo-se publicações e apresentações em congressos, no limite da ética e do proceder íntegro e idôneo. A participação nesta pesquisa é total e completamente isenta de qualquer ônus financeiro. Em qualquer fase da pesquisa é garantida, aos participantes, a possibilidade de se recusarem a continuar ou de retirarem o seu consentimento sem nenhum tipo de sanção; bem como a liberdade de buscar, junto à pesquisadora, esclarecimentos de qualquer natureza.

Data Nome: Assinatura: 